\title{
Johannes Holthusen
}

\section{Rußland in Vers und Prosa}

\author{
Vorträge zur russischen Literatur \\ des 19. und 20. Jahrhunderts
}

Verlag Otto Sagner München · Berlin · Washington D.C.

Digitalisiert im Rahmen der Kooperation mit dem DFG-Projekt „Digi20“

der Bayerischen Staatsbibliothek, München. OCR-Bearbeitung und Erstellung des eBooks durch den Verlag Otto Sagner:

http://verlag.kubon-sagner.de

() bei Verlag Otto Sagner. Eine Verwertung oder Weitergabe der Texte und Abbildungen, insbesondere durch Vervielfältigung, ist ohne vorherige schriftliche Genehmigung des Verlages unzulässig. 


\section{SLAVISTISCHE BEITRÄGE}

BEGRUNDET VON ALOIS SCHMAUS

HERAUSGEGEBEN VON HENRIK BIRNBAUM UND JOHANNES HOLTHUSEN

REDAKTION: PETER REHDER

Band 69 
JOHANNES HOLTHUSEN

RUSSLAND IN VERS UND PROSA

VORTRÄGE

ZUR RUSSISCHEN LITERATUR DES 19. UND 20. JAHRHUNDERTS

VERLAG OTTO SAGNER • MÜNCHEN

1973 
ISBN 3876900794

Copyright by Verlag Otto Sagner, München 1973 Abteilung der Firma Kubon und Sagner, München Druck: Alexander GroBmann

8 München 19, Ysenburgstraße $7^{I}$ 


$$
v \circ r \quad v \circ r t
$$

$\mathrm{Zu}$ dem Gedanken, die hier in einer Sammlung vereinten Vorträge einer erweiterten offentlichkeit zu unterbreiten, haben die Diskussionen mit den engsten Mitarbeitern im Seminar für Slavische Philologie der Universität München den entscheidenden AnstoB gegeben. Wie der Leser bemerken wird, handelt es sich bei dieser Sammlung nicht um einen geschlossenen Vortragszyklus, sordern un thematisch und - was die Entstehungszeit angeht - auch chronologisch breiter gestreute $\mathrm{Zu}-$ sammenfassurigen von Arbeitsergebnissen und Gedanken, die für den mündlichen Vortrag vor den jeweils genannten Zuhörerkreisen bestimmt waren.

Um den lirsprünglichen Charakter dieser Darlegungen zu bewahren, habe ich die Formulierungen direkt aus den Vorlesungsmanuskripten übernommen, ohne entscheidende Abstriche und ohne nachträgliche Erweiterungen. Der Wortleut wurde zwar in allen Fällen überprüft und für den Zweck der Drucklegung, wo nötig, korrigiert, jedoch habe ich auf alle sachlichen finderungen verzichtet. Dadurch sind sowohl der Vortragsstil als auch der eigene Erkenntnisstand des jeweile angegebenen Vortragsdatums unangetastet geblieben. Eine Ausnahme mußte lediglich im Fall des Vortrages "Das Erzählen bei Isaak Babel' und bei Boris Pil'njak" gemacht werden, da zu diesem Vortrag nur konzeptartige Aufzeichnungen benutzt wurden. Diese werden hier neu formuliert und um einige Punkte ergänzt vorgelegt. Um die Einheitlichkeit des Stils zu gewährleisten, wurde die Vortragssituation auch hier rekonstruiert.

$\mathrm{Da}$ die Thematik der Vorträge größerenteils in engem $\mathrm{Zu}-$ sammenhang mit speziellen wissenschaftlichen Arbeitsvorhaben gestanden hat, wird der interessierte Leser in einem Anhang auf Veröffentlichungen des Autors hingewiesen, in denen solche Zusammenhänge gegeben sind. 
Bei der redaktionellen Vereinheitlichung des Bildes der verschiedenen Vorträge, insbesondere bei der konsequent durchgehaltenen Anführung der zahlreichen Textbeispiele im vollen Wortlaut der russischen Originalsprache und in deutscher tbersetzung, konnte ich mich der tatkräftigen Unterstützung von Fräulein Dr. Johanna Renate Döring und Herrn Dr. Peter Rehder erfreuen. Ihnen beiden sei an dieser Stelle sehr angelegentlich gedankt. Wo auf deutsche tbersetzungen nicht eigens in den Literaturangaben hingewiesen wird, stammen diese von beiden Mitarbeitern bzw. von mir selbst.

Auf einen Anmerkungsapparat wurde aus grundsätzlichen Erwägungen verzichtet, da Fußnoten zwangsläufig das Problem einer Neugestaltung des Textes aufgeworfen hätten. Die zitierten Texte sind in den Literaturangaben belegt, genauere Stellennachweise erschienen mir dabei entbehrlich. Verweise auf namentlicb genannte oder implizit behandelte Dichter und Literáturwissenschaftler wurden nach Möglichleit ebenfalls in die Literaturangaben aufgenommen. Darüber hinaus dankt der Verfasser allen ungenannt gebliebenen Freunden, Kollegen und Schülern für die wichtigen Anregungen, die er im Laufe zweier Jahrzehnte von ihnen empfangen hat.

Für die äußere Gestaltung und Bearbeitung, die in bewährter Weise Herr Dr. Peter Rehder übernommen rat, danke ich bei dieser Gelegenheit dem Betreuer der Reihe "Slavistische Beiträge" besonders herzlich, ebenso wie allen Mitarbeitern des Seminars für Slavische Philologie der Universität München, die die schnelle Herstellung der Druckvorlage ermöglicht haben.

Dem Verlag Otto Sagner und Herrn Otto Sagner persönlich danke ich für langjährige verständnisvolle Zusammenarbeit,der diese Reihe ihre Existenz verdankt.

München, im August 1973

J. Holthusen 
I N H A L T S VERZEI C H N I S

Petersburg als literarischer Mythos ...........99

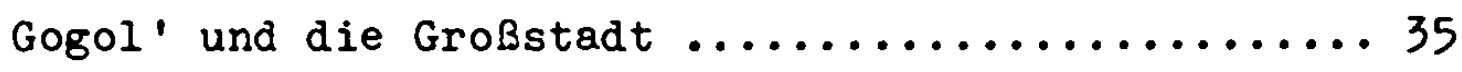

Geschichte und Utopie im russischen

Symbolismus ....................... 58

Probleme der frühen Sowjetliteratur

(Prosa, Drama) .................... 82

Das Erzählen bei Isaak Babel' und bei

Boris Pil'njak ........................ 112

Zur Interpretation zeitgenössischer

sowjetrussischer Lyrik ................ 139

Probleme der neueren Sowjetliteratur

(Versdichtung) .....................161

Solženicyns Erzählkunst ................ 187

Verzeichnis weiterer, thematisch anknüpfender Arbeiten des verfassers ............. 211 


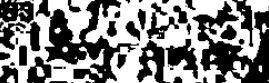

1.

4 of

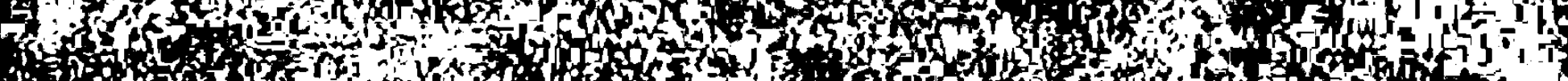

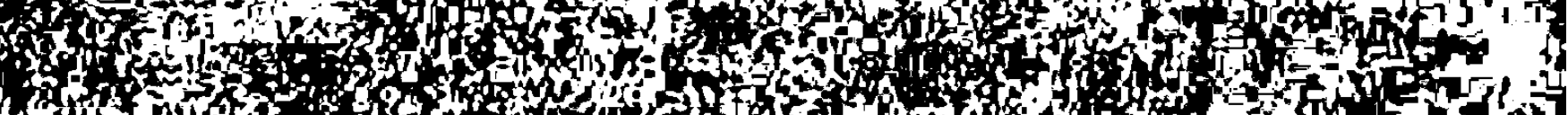
Hof

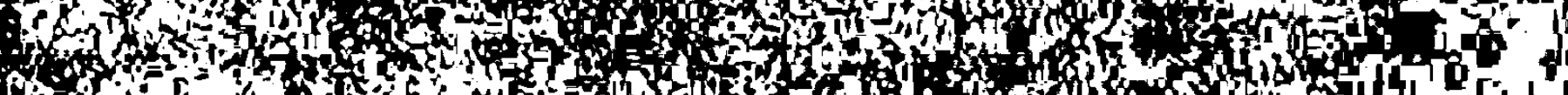

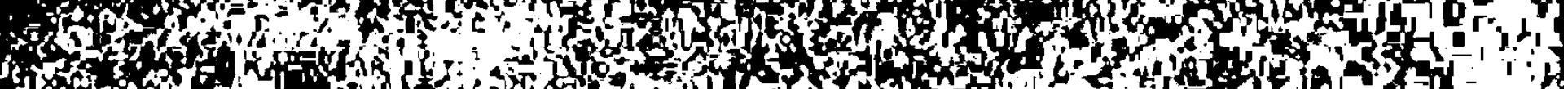
Af

$\because$ I 3 I 40,0 ,

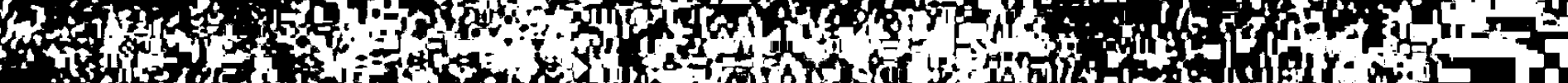
(4)

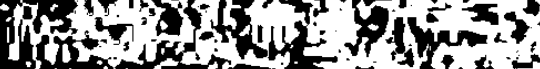

(1)

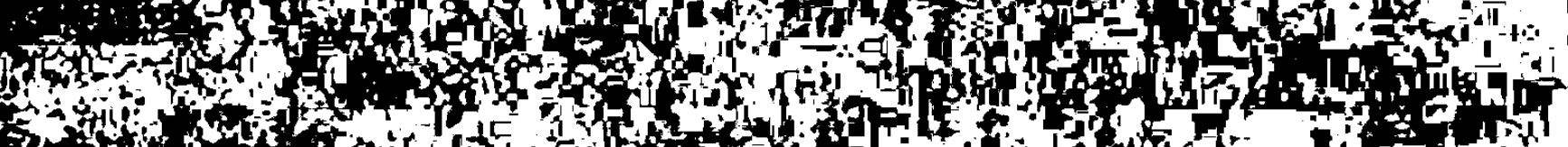
(1)

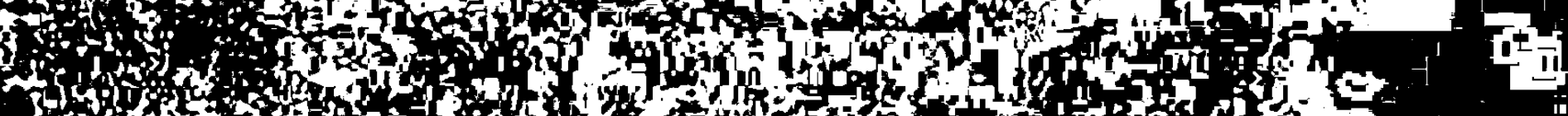

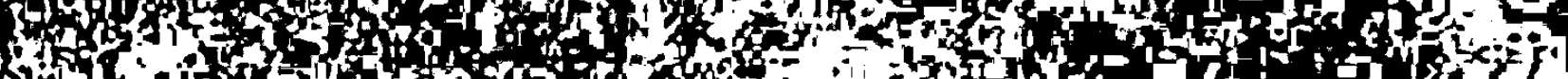

X.

(4)

(1)

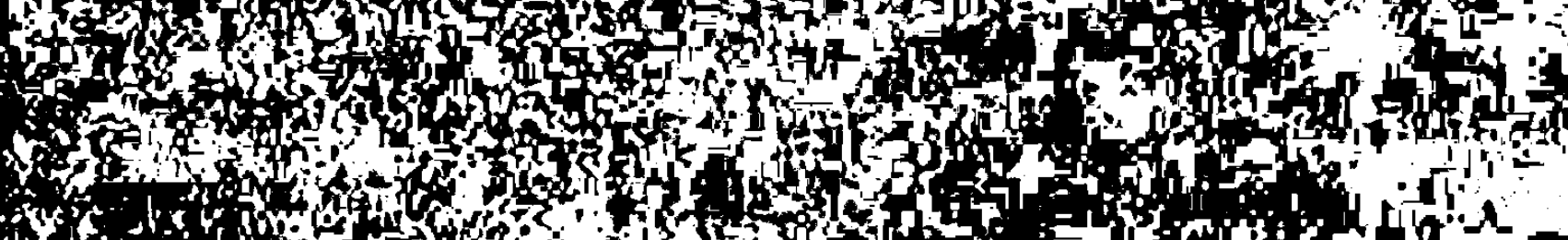

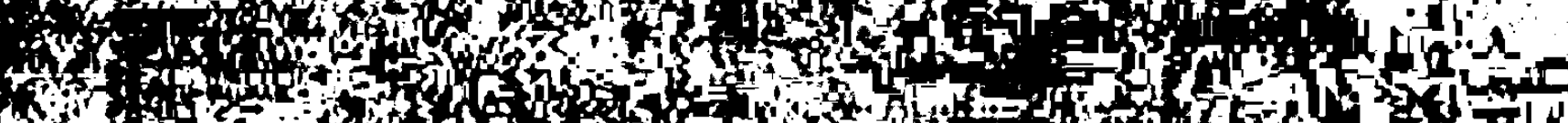
- X

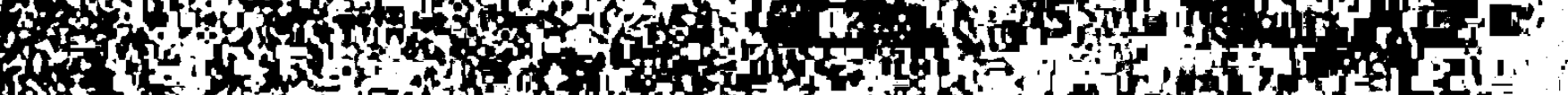

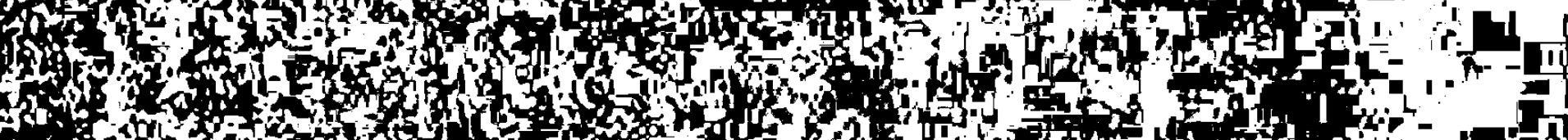

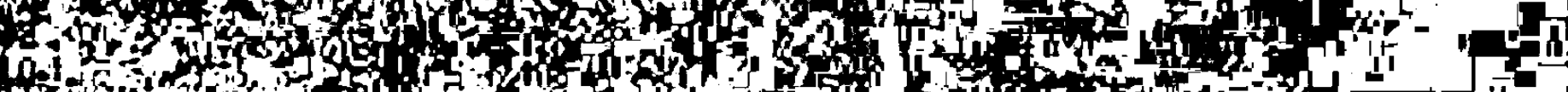

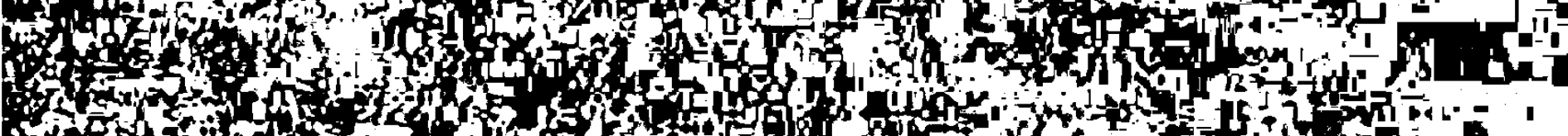

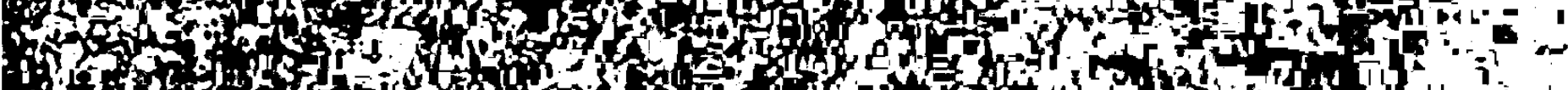

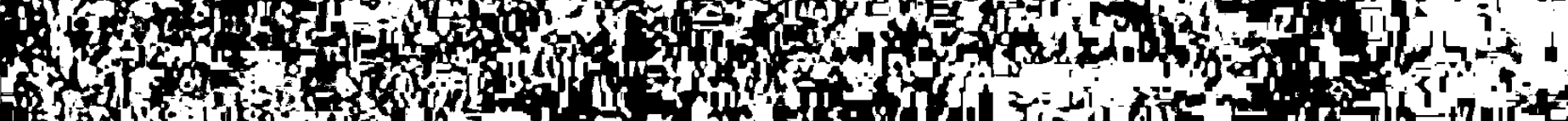

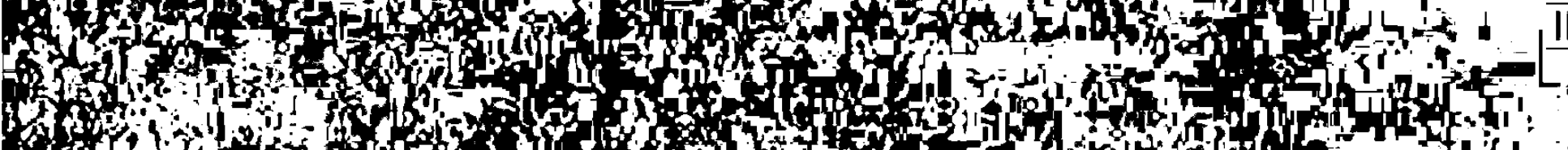
13.

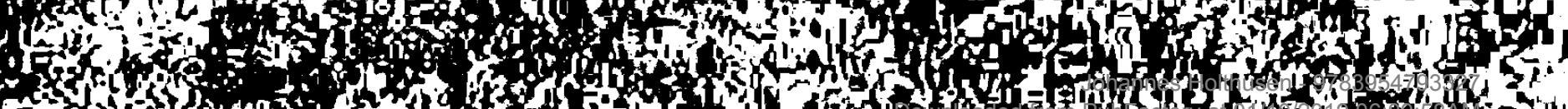

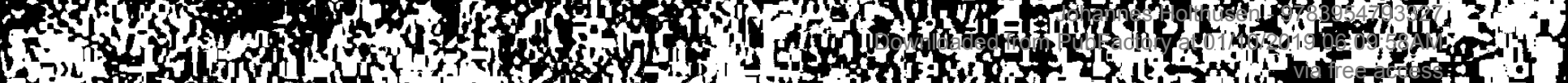


Das literarische Leben der verschiedenen Völker spielt sich offensichtlich nicht nur in zeitlicher, sondern häufig auch in räumlicher Zyklisierung ab, es gruppiert sich von Zeit zu Zeit um gewisse Zentren, die zu besonderer literarischer Bedeutung aufsteigen. Das literarische Prag kurz vor dem ersten Weltkrieg wäre ein solches Beispiel, Berlin in den zwanziger Jahren, und immer wieder Paris, das literarische Zentrum par excellence.

Sehr vieles ließe sich hier noch anführen, wenn wir weiter in Mittel- und Westeuropa verweilen würden, doch soll unser Blick heute auf Osteuropa ruhen, genauer gesagt auf Nordosteuropa, denn St. Petersburg, die Residenzstadt des russischen Kaiserreiches seit Peter dem Großen, hatte zweifellos immer einen sehr nördlichen Anstrich. Zur Zeit Puškins wurde Petersburg in umschreibender Redeweise das "nördliche Palmyra" genannt, und es wäre gewiß einer Untersuchung wert, wie vielfältig das Epitheton "nördlich" (servernyj), oft auch durch "nordisch" wiedergegeben, in der Petersburger Literatur Verbreitung gefunden hat. Man braucht z.B. nur an Puškins Sentenz aus dem "Evgenij Onegin" zu denken:

\footnotetext{
"Но наше северное лето, Карикатура юхных зим..."

[Aber unser nordischer Sommer/ist eine Karikatur der Winter im Süden .... .]
} 
Die "Weißen Nächte", in denen die Sonne kaum unter dem Horizont verschwindet, hat Dostoevskij in einer seiner Erzählungen der Weltliteratur einverleibt, und in den zwanziger Jahren des vorigen Jahrhunderts zögerte man sogar nicht einmal, einen Petersburger literarischen Almanach "Polarstern" [Poljarnaja zve zu nennen. Gleich darauf folgten die "Nordischen Blumen" [Severnye cvety], und als Namen für Almanache, Zeitungen und Zeitschriften sind aus dem 19. Jhdt. zu belegen: "Nordische Lyra" [Severnaja lira], "Nordische Minerva" [Severnaja Minerva], "Nordische Post" [Severnaja počta], "Nordische Biene" [Severnaja pčela], "Nordlicht" [Severnoe sijanie], "Nordischer Bote" [Severnyj vestnik] und andere ähnlich gebildete Titel.

Petersburg verstand sich selbst also eher als nordeuropäisch denn als osteuropäisch, und die Nähe Skandinaviens hatte ja schon am Beginn der russischen Geschichte dazu geführt, daß die Nordmänner (die Winkinger bzw. die Waräger) vom Ladogasee aus die Fahrt nach dem Süden antraten, die sie bis gen Byzanz und darüber hinaus führen sollte. Petersburg, die Hauptstadt des kaiserlichen russischen Imperiums, ist eine späte Gründung, wie genugsam bekannt ist. Kiev und Moskau sind die historischen Hauptstädte, Petersburg dagegen wurde von dem germanophilen Zaren Peter 1703 gegründet, an der sumpfigen und durch tberschwemmungen bedrohten Mündung der Neva, unweit der schwedischen Festung Nienschanz, die Peter 1702 erobern konnte. Der deutsch-niederländische Name der Stadt Sanktpeterburg oder Piterburch weist deutlich genug auf den für die Russen fremdartigen Charakter der Stadt hin, nicht ohne Grund wurde die Stadt während des I. Weltkrieges in"Petrograd" umbenannt. 
Uber die Erbauung der Stadt und ihrer Festungswerke gibt es mehr Gerüchte als zuverlässige dokumentarische Unterlagen, aber gerade diese Gerüchte bilden gleichsam die Basis für den Mythos von Petersburg, wie er sich in der russischen Literatur einnisten sollte.

Der durch seine christliche, literarisch-philosophische Publizistik bekannte Dmitrij Merežkovskij schreibt - bereits einige Zeit nach der Revolution von 1905 - in einem seiner Essays ("Regenbogen in Winter" [Zimnie radugi]):

"В 17 I4 году Петр задумал умнохить Петербург; заметив, что в городе медленно строились дома, царь запретил во всем государстве, кроме Петербурга, сооружать каменные здания, с угрозою в противном случае разорения имения и ссылки. Постановлено было на всех судах, приходивших в Петербург через Ладожское озеро, также на всех подводах привозить камень и сдавать его оберкомиссару...

Еще бы не "умышленный" город! Рабочие, которых сгоняли, как скот, со всех концов России, пели заунывную песню:

Подымались добры молодцы,
Добры молодцы, люди вольные,
Все ребятушки понизовые
На работушку государеву.

Вӧплощение этой "не своей воли" и есть Петербург. При возведении первоначальных укреплений нужна была земля, а ея поблизости не находилось: кругом была только трясина, покрытая мхом; землю таскали к бастионам из дальных мест в старых мешках, рогожах, или дахе просто в полах платья. Люди оставались без хлеба, без крова и мерли, как мухи. Покойников не успевали хоронить и волокли, как падаль, в общую яму. Сооружение Петропавловской крепости стоило жизни ІОО тысяч переселенцев.'

[Peter beschloB im Jahre 1714, Petersburg zu vergrößern: da er merkte, daB die Häuser in der neuen Stadt sehr langsam gebaut wurden, erließ er ein Verbot, in ganz Rußland, außer Petersburg, steinerne 
Häuser zu errichten; Zuwiderhandelnden drohte Konfiskation des Eigentums und Verbannung. Alle Schiffe, die durch den Ladogasee nach Petersburg fuhren, sowie alle Fuhrwerke waren verpflichtet, eine gewisse Menge Bausteine mitzunehmen und dem Oberkommissar abzuliefern .... Und das soll keine 'erdachte' Stadt sein! Die Arbeiter, die aus ganz RuBland wie Vieh zusammengetrieben wurden, sangen das traurige Klagelied:

Tüchtige Burschen haben sich auf den Weg

Tüchtige Burschen, freies Volk, gemacht, Alles Kinder aus den Niederungen Zur Fronarbeit für den Zaren.

Die Verkörperung dieses 'fremden Willens' ist $\mathrm{Pe}-$ tersburg. Für die Errichtung der Fundamente brauchte man Erde, Erde war aber in der Nähe nirgends zu finden; es gab nur moosbewachsenes Moor. Frde für die Bastionen wurde aus weiter Entfernung in alten Säcken, Bastdecken und oft sogar in Rockschößen herbeigeschleppt. Die Menschen hatten kein Obdach und kein Brot und starben wie die Fliegen. Man hatte nicht Zeit, die Leichen einzeln zu beerdigen; alle wurden wie Aas in eine gemeinsame Grube geworfen. Die Errichtung der Peter-Pauls-Festung allein kostete 100000 Umsiedlerleben.]

Merežkovskij ist nach der Revolution von 1905, nach der politischen Enttäuschung, die ihn für drei Jahre ins Ausland trieb, der bitterste Feind Petersburgs und Peters des Großen. Angewidert spricht er von

"...невероятной, черно-коричневой жиже среди
невероятного, черно-желтого тумана..."

[unglaublichem schwarzbraunen Schmutz inmitten eines unglaublichen schwarzgelben Nebels]

und er erinnert sich an sein Pariser Exil:

"надо прохить несколько лет в Европе, чтобы почувствовать, что Петербург все еще не европейский город, а какая-то огромная каменная чухонская деревня. Невытанцовавшаяся и уже запакощенная Европа."

[Man muB mehrere Jahre in Westeuropa gelebt haben, um zu begreifen, daB Petersburg noch immer keine europäische Stadt, sondern ein kolossales steinernes Finnendorf ist. Ein unausgegorenes und doch schon verdrecktes Europa.]

Das Antlitz Petersburgs vergleicht Merežkovskij in dem glei- 
chen Essay ohne Umschweife mit dem Antlitz des Todes, Facies Hypocratica, wie er gelehrt hinzufügt.

Merežkovskij selbst gehörte zur Petersburger literarischen Welt, zur Petersburger Literatur im genaueren Sinne, und gerade seine paradoxe Einstellung scheint mir zum Interessantesten zu gehören, was uns unser Problem bietet: Petersburg im Urteil der russischen Intelligenz. Bevor wir das Problem weiter entwickeln, muß ich noch auf einen Aspekt des Ablehnungskomplexes gegen Petersburg eingehen, der historisch und gefühlsmäßig bedingt ist: die "Rivalität" zwischen Petersburg und Moskau. Merežkovskij kann uns da gleich mitten hineinführen:

"Недавно ездил я в Москву... Люди,как люди; город, как город. Веселые санки скрипят по крепкому снегу, и можно не бояться, что завтра превратится он в черную слякоть... И вот еще что. Как это ни странно, но в некоторых уголках Кремля я чувствую себя, как на старых площадях Пизы, Флоренции, Перуджии: не даром строили эти соборы и башни, вместе с русскими каменщиками, итальянские зодчие. Я здесь ближе к подлинной святой Евpone, чем в Петербурге...

Из русской земли Москва выросла и окружена русской землей, а не болотным кладбищем с кочками вместо могил и могилами вместо кочек. Москва выросла Петербург вырощен, вытащен из земли, или даже просто "вымышлен"."

[Kürzlich bin ich nach Moskau gefahren ... Die Menschen sehen wie Menschen aus; die Stadt - wie eine Stadt. Der Schlitten fliegt lustig über den festen, knirschenden Schnee, und man muB nicht Angst haben, daB der Schnee sich schon morgen in schwarzen Brei verwandeln wird .... Und dann noch etwas: Wie seltsam es auch klingt, ich fühle mich in gewissen Winkeln des Kremls wie auf den alten Plätzen von Pisa, Florenz und Perugia; nicht umsonst haben an der Erbauung dieser Dome und Türme neben russischen Steinmetzen auch italienische Baumeister mitgearbeitet. Hier bin ich dem echten, heiligen Westeuropa näher 
als in Petersburg ... Moskau ist aus russischer Erde emporgewachsen und von russischer Erde und nicht von einem sumpfigen Priedhof umgeben, mit feuchten Mooshügeln statt Gräbern und Gräbern statt Mooshügeln. Moskau ist selbst emporgewachsen, Petersburg aber wurde gezüchtet, aus der Erde herausgezogen oder sogar einfach 'ausgedacht'.]

So schließt Merežkovskij unter Benutzung eines Zitates aus Dostoevskijs "Zapiski iz podpol'ja" [Aufzeichnungen aus dem Kellerloch], wo Petersburg als unbeimlich "abstrakte" und "ausgedachte" Stadt gekennzeichnet wird.

Moskau als die alte "russische" Hauptstadt stand dem echten Gefühl und auch den natürlichen menschlichen Bedürfnissen der Russen auch in der ersten Hälfte des 19. Jhdts. näher als Petersburg. Die Gegenüberstellung Moskaus und Petersburgs hat als literarische Tradition vor allem Gogol' entwickelt. In seinem Feuilleton "Peterburgskie zapiski 1836 goda" [Petersburger Notizen 1836] lesen wir:

\footnotetext{
"Петербург весь шевелится, от погребов до чердака; с полночи начинает печь французские хлебы, которые назавтра все съест немецкий народ, и во всю ночь то один глаз его светится, то другой; Москва ночью вся спит, и на другой день, перекрестившись и поклонившись на все четыре стороны, выезжает с калачами на рынок."
}

[Petersburg ist ständig in Bewegung, vom Keller bis zum Dachboden; schon um Mitternacht fängt es an, französische Brote zu backen, die alle am nächsten Morgen von den deutschen Einwohnern verspeist werden, und die ganze Nacht leuchtet hier sein eines Auge, dort sein anderes. Moskau schläft nachts fest, und am nächsten Morgen, wenn es sich nach allen vier Seiten bekreuzigt und verneigt hat, fährt es mit seinen Kringeln zum Markt.]

Moskau, so doziert Gogol', ist weiblichen, Petersburg männlichen Geschlechts. Moskau wartet mit seinen Bräuten auf, Petersburg mit seinen Freiern. Moskau ist RuBlands Vorratskammer, Petersburg der Ort des schnellsten Verbrauchs. 
"RuBland braucht Moskau", so argumentiert Gogol', aber "Petersburg braucht Rußland" [Moskva nužna dl ja Rossii; dlja Peterburga nužna Rossija.]

Nach Gogol' gibt es noch viele solcher Vergleiche zwischen Moskau und Petersburg bei den Vertretern der sog. naturalistischen Schule [natural'naja skola] in den vierziger Jahren des 19. Jhdts. Und dabei wird vor allem unterstrichen, daß Moskau die Stadt mit den geheiligten Traditionen ist, Petersburg aber eine geschäftige und "windige" Stadt, ohne jede Tradition. In dem satirischen Reiseroman des Grafen Sollogub mit dem Titel "Tarantas" [Der Tarantas] heißt es z.B.:

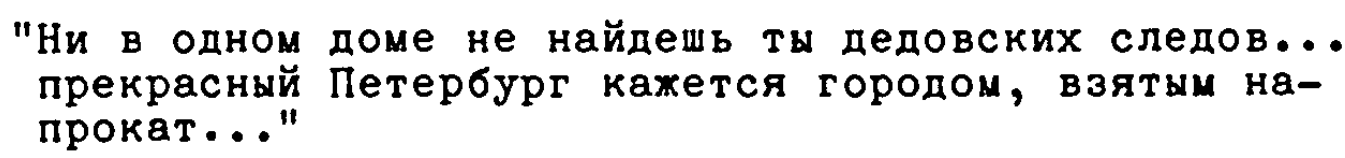

[In keinem Haus findest du Spuren der Voreltern ... das prächtige Petersburg erscheint wie eine Stadt, die nur angemietet ist.J

Petersburg ist das steinerne Gehäuse der deutsch-russischen Bürokratie, und man kann verstehen, daß diese Bürokratie den Russen nicht eben sympathisch war. Der gehetzte, ja an den Rand des Wahnsinns getriebene Beamte ist der Held der Petersburger Literatur der dreißiger und vierziger Jahre des 19. Jhdts. Denken wir nur an den armen Popriščin aus F̄ogol's "Zapiski sumasšedక̌go" [Aufzeichnungen eines Wahnsinnigen] oder an Akakij Akakievič, an Gogol's Geschichte vom "Mantel" [Sinel']. Graf Sollogub schreibt - ebenfalls im "Tarantas" -

"Весь Петербург кахется огромным департаментом, и дахе строения его глядят министрами, директорами, столоначальниками, с форменными стенами, с вицмундирными окнами."

[Ganz Petersburg erscheint wie ein riesiges Büro, und sogar seine Häuser sehen aus wie Minister, Direktoren, Abteilungsleiter, mit Uni fommïnden, 97 mid 93327 Vizeuniformfenstern.] 
Wann und wo hat diese Kritik an Petersburg, an dem unrussischen Wesen dieser Stadt ihren Anfang genommen? Die Beantwortung dieser Frage führt uns mitten in das Problem der eigentlichen Petersburger Literatur hinein.

Nichts dergleichen läßt sich in der klassizistischen Literatur des 18. Jhdts. entdecken. Die russischen Dichter des 18. Jhdts., die der Gunst des Hofes bedurften und sich wohl auch gern der Gunst des Hofes erfreuten, hatten scheinbar noch ein völlig naives Verhältnis zu Petersburg, vor dessen imperialem Namen sie die schuldige Ehrfurcht bezeigten. Sumarokov, der große Rivale Lomonosovs, war z.B. einer derjenigen, dessen Karriere ganz mit der Residenzstadt verbunden war. Das zeigt sich vielleicht nirgends so deutlich wie in der "horazischen" Ode auf die Geburt des Prinzen und nachmaligen Zaren Pauls I., $1754:$

"Скажи свое веселье, Нева, ты мне,
Что сталося за счастие сей стране?"

[Nenne mir deine Freude, Nevg/was für ein Glück ist über dieses Land gekommen?]

so fängt die Ode an, unc in zwölf horazischen Strophen wird nun die kaiserliche Familie, werden ihre unvergeßlichen Taten gerühmt. Mindestens in jeder zweiten Strophe ist von Peter I. die Rede, für sein Werk wird Gedeihen und beständiges Wachstum erfleht:

\footnotetext{
"Посеянные им, возрастайте вы, Науки, на брегах чистых вод Невы, Труды Петровы, процветайте, Музы, на Севере обитайте."
}

[Die ihr von ihm gesät seid, wachst empor,/Wissenschaften, an den Uferm der reinen Nevafluten $\sqrt{ }$ Werke Peters, blüht weiter auf,/Musen nehmt im Norden Wohnung.] 
1756 dichtet Sumarokov eine Inschrift für das Häuschen Peters des Großen "K domiku Petra Velikogo", in der es heiBt:

"Льзя ль пышный было град сим домом обещать?
Никто не мог того в то время предвещать;
Но то исполнилось; стал город скоро в цвете...;
Каков сей домик мал, так Петр велик на свете."

[Konnte dieses Haus ein Versprechen auf die Pracht der Stadt sein?/Niemand konnte das zu jener Zeit prophezeien;/aber gleichwohl ist es in Erfüllung gegangen; in Blüte stand bald die Stadt .../So klein dies Häuschen ist, so groB ist für die ganze Welt Peter.]

Ein anderes Gedicht, eine Epistel Sumarokovs, wiederholt den Wunsch, daß auch die Musen an der Neva heimisch werden möchten:

"Желай, чтоб на брегах сих музы обитали,
Которых вод струи Петром преславны стали.
Октавий Тибр вознес, и Сейну - Лудовик."

[Wünsche dir, daß die Musen auch an diesem Strand Wohnung nehmen, dessen Wasserfluten durch Peter. weltberühmt wurden. Octavius hat den Tiber erhöht, die Seine aber Ludwig.]

Hier wird Petersburg neben Rom und Paris gestellt. Und so wurde es unter den Klassizisten auch bald üblich, statt Petersburg den größeren Namen "Petropol"" (Petropolis) zu gebrauchen. Als eine Tragödie Sumarokovs bei der Kritik durchfiel, klagte der Dichter in einer Elegie 1770 sein Leid den Wellen der Neva:

"О вы, кропящие Петрополь невски волны, Сего ли для, ах, Петр храм музам основал. Я суетно на вас, о музы, уповал!"

[0 ihr Nevawellen, die ihr Petropolis benetzt,/hat dafür, ach, Peter den Tempel der Musen gegründet!/ Vergeblich habe ich auf euch, o Musen, gesetzt.]

Diese Tradition bleibt das ganze 18. Jhdt. über lebendig, sie wird vor allem durch Deržavin fortgesetzt, wie dessen Ode auf die Geburt des späteren Zaren Alexanders I. (1777) 
zeigt. Gerade die Rede vom "nördlichen" Imperium, von der "rördlichen" Residenz entstammt dieser klassizistischen Tradition. Die tberschrift zu Deržavins Ode lautet nämlich: "Auf die Geburt des purpurgeborenen Knaben im Norden" [Na roždenie v Severe porfirorodnogo otroka].

Ganz sicher hängen die dichterischen Huldigungen an Petersburg auch eng mit der klassizistischen Gattungspoetik zusammen. Die durch den Kanon vorgeschriebenen bzw. "erlaubten" Gattungen sahen die Huldigung eigens vor: feierliche Poesie ist im 18. Jhdt. noch ganz Odenpoesie. Die Elegie läßt Raum für Schmerz, aber nicht für historische Polemik, die Satire rat Laster zu geißeln, nicht aber staatlich geschützte Traditionen anzugreifen.

Der Mythos von dem Unwesen der Petersburger Kultur hat daher auch erst literarische Gestalt annehmen können, nachdem das Gefüge der alten Gattungen im Namen der Romantik zum Einsturz gebracht worden war. Diese Zertrümmerung der Gattungen fällt zusammen mit dem Werk Alexander Puškins, und Puškin war es denn auch, der als erster rein Petersburger Dichter den Vorhang zerriß, der das ardere Antlitz Petersburgs bisher verhüllt hatte. Zugegeben sei, daß sich die Widersprüche zum Beginn der 30er Jahre des 19. Jhdt. verschärft hatten, Petersburg war auf dem Weg, eine Großstadt des 19. Jhdt. zu werden. Unentbehrlich war aber auch dies: die Emanzipierung der Literatur vom Zarenhof, und welchen Preis Puškin dafür gezahlt hat, ist bekannt: die Mißgunst der Hofgesellschaft hat Puškin, der der ständigen Intrigen müde geworden war, zu jenem schändlichen Duell getrieben, in dem er tödlich getroffen warde.

Puškins Haltung wird vielleicht gerade in einem Gedicht besonders deutlich, das ein Vermächtnis an die Nachwelt ist, 
das berühmte Gedicht, das er als sein "Denkmal" ansah. In Anlehnung an das horazische "Exegi monumentum" spricht Puškin hier 1836 (ein knappes Jahr vor seinem Tode) von seinem Werk, diesem wahrhaften Monument, das sich nach des Dichters eigenen Worten mit seinem freien Haupt höher erhebt als die Alexandersäule, die, 1834 errichtet, die Taten des Zaren Alexanders $I$. verherrlichen sollte.

Es ist bekannt, daß sich der Dichter bei der Enthüllung der Alexandersäule entschuldigen ließ, und man kann ahnen, warum.

Bezeichnenderweise spielt in dem "fatalen" Mythos Petersburgs ebenfalls ein Denkmal die Hauptrolle, und Puškin ist derjenige, der diese Rolle dichterisch formuliert hat in seiner "Petersburger Erzählung" in Versen, dem "Mednyi vsadnik" 1834 [Eherner Reiter]. Es handelt sich um das Denkmal Peters des Großen, bestellt von Katharina II. bei dem Pariser Bildhauer Falconet, enthüllt 1782. Das Denkmal zeigt den Zaren rittlings auf einem Pferd, das die Vorderhufe ins Leere erhoben hat und mit den Hinterhufen eine sich krümmende Schlange zertritt, ein Einfall, der wohl auf ein altes mit Herakles dem Schlangentöter verbundenes stoisches Motiv für die tberwindung von Hindernissen und Feinden, für die Ausrottung von irrigen Fehlern zurückgeht.

Dieses auf einen roh bearbeiteten Granitsockel gehobene Denkmal beherrscht noch heute den Petersplatz an der Neva, aber in der Petersburger Literatur spielt es die Rolle des wohl eigenartigsten Symbols. Sogar der polnische Dichter Adam Mickiewicz hat diesem Denkmal in einem seiner größeren Epen ("Dziady" [Totenfeier]) eine Digression gewidmet. Peter, auf ungezügeltem Roß, gleichsam in ziellosem Absprung über dem 
Abgrund des Granitfelsens schwebend, wird von ihm mit einem vereisten Wasserfall verglichen, der über einem felsigen Absturz hängt. An dieses Bild knüpft Mickiewicz die rhetorische Frage: "Was wird aus dieser Kaskade der Tyrannei, wenn erst die Sonne der Freiheit blinkt, wenn erst der warme Westwind über dieses Land hinwegstreicht?" Interessant ist das Datum dieser Frage, sie wurde 1829 gestellt, ein Jahr vor dem polnischen Aufstand von 1830.

Puškin arbeitet an seiner Dichtung vom "Ehernen Reiter" freilich mit einer anderen "klimatischen" Symbolik. Seine Erzählung geht aus von der großen tberschwemmung der Neva in Petersburg am 7. November 1824. Puškin, der diese tberschwemung selbst nicht miterleben mußte, da sie in seine Verbannungszeit fällt, reagierte damals fast schadenfroh. Er schrieb in einem Brief kurz nach dem 20. November 1824 aus Michajlovskoe an seinen Bruder Lev Sergeevič Puškin ("Adres: L'vu Sergeeviču Puškinu v sobstvennye lapki"): "Was ist bei euch los? Eine tberschwemmung? Das macht doch dem verfluchten Petersburg nichts! Voilà une belle occasion à vos dames de faire bidet."

Zehn Jahre später, im "Ehernen Reiter", zeigt diese Uberschwemmung deutlich ihren bèdrohlichen Aspekt. Wenn Puškin das Reiterdenkmal und die tberschwemmung in einem Atemzug nennt, so ist die Implikation natürlich, daß Peter der Große die Stadt an einer Stelle erbaut hat, die eigentlich ohne Grund ist, über die die Wassermassen jeden Augenblick hereinbrechen können, wenn der gefährliche Westwind das Wasser in die Neva zurückdrückt.

Eugen [Evgenij], der Held der Erzählung, hat das Unglück, daß durch die Uberschwemmung das hölzerne Häuschen, in dem 
seine Braut wohnt, und mit dem sich alle seine Träume verbinden, hinweggespült wird. Paraša kommt mit ihrer Mutter in den Fluten um.

Der wahrhaft romantische Gedanke der Erzählung ist nun der, daß Puškin seinen Evgenij ein Duell mit dem Ehernen Reiter auskämpfen läßt, das natürlich nur mit der Erniedrigung Evgenijs enden kann. Die Macht ist zu ungleich verteilt.

Der Höhepunkt der hintergründigen Auseinandersetzung ist Evgenijs verbale Herausforderung an das Denkmal - eine Art Transposition des Don Juan-Motivs und der Herausforderung des Komturs -: hier prallen verletztes Recht und dämonische Macht aufeinander. Eugen geht um das Denkmal herum und stellt sich zum ersten Mal Angesicht in Angesicht seinem geheimen Widersacher. Mit wildem Trotz blick' er zu dem Reiter empor, aber auf einmal wird ihm schwarz vor Augen. Er preBt die Stirn gegen das kalte Gitter, ringt ohnmächtig die Hände und schleudert die drohende Herausforderung gegen den Reiter:

\footnotetext{
"Добро, строитель чудотворный! Шепнул он, злобно задрохав, Ухо тебе!..."
}

[Schön, du wundertätiger Baumeister!/ - flüsterte er, voll Zorn erbebend,/wart du nur! ....

Bei diesen Worten fährt ihm plötzlich der Schreck in die Glieder, er hat den Eindruck, daß das Gesicht des Reiters sich bewegt und einen zornigen Ausdruck bekommen hat. Evgenij wendet sich zur Flucht, aber hinter ihm ertönt schon das metallene Klirren der Hufe, der Reiter verfolgt Evgenij in einer gespenstischen Hetzjagd durch das nächtliche Petersburg. Dieses Trauma kann Evgenij nicht mehr loswerden, im Epilog ist als bittere Ironie der Hinweis zu finden, daß Evgenij künftig jedes Mal mit gesenkten Augen am Denkmal vorbeischleicht, 
eine Hand hat er dabei an sein Herz gepresst, mit der anderen zieht er ehrfürchtig die Mütze vom Kopf.

Eine Ironie des Schicksals ist es, daß der russische Rritiker Belinskij dieses Werk in seiner hegelianischen Periode als Apotheose Peters des Großen verstanden hat, als "Triumph des Allgemeinen über das Einzelne". Belinskij kann man zwar zugute halten, daß der Prolog der Dichtung Peter den Großen und Petersburg ausdrücklich rühmt, doch soll diese Einleitung gerade die Kluft zwischen äuBerem Glanz und innerem Elend, zwischen Schein und Sein aufreißen. Puškins entscheidender neuer Gedanke ist getragen vom Wissen um die Fatalität dieser Stadt, neu sind die dämonischen Züge Peters.

Später sollte Belinskij dann auch selber auf die von Puškin gewiesene neue Linie einschwenken. 1845 lieB er sich anders vernehmen:

"Петербург строился зкспромтом: в месяц делалось то, чего бы стало делать на год... Казалось, сама судьба, вопреки всем расчетам вероятностей, захотела забросить столицу Российской империи в зтот неприязненный и враждебный человеку природою и климатом край... где болотистые испарения и разлитая в воэдухе сырость проникают и каменные дома и кости человека; где нет ни весны, ни лета, ни зимы, но круглый год свирепствует гнилая и мокрая осень, которая пародирует то весну, то лето, то зиму..."

[Petersburg wurde improvisiert: in einem Monat wurde das getan, wofür man sich ein Jahr hätte Zeit nehmen sollen ... Anscheinend wollte das Schicksal selbst entgegen allen Rechnungen der Wahrscheinlichkeit die Hauptstadt des russischen Imperiums in diesen Winkel verbannen, der so ungastlich und durch seine Natur und sein Klima dem Menschen so feindlich ist ... wo sumpfige Ausdünstungen und die in der Luft schwebende Feuchtigkeit ebenso in die Häuser aus Stein dringen wie in die Knochen der Menschen, wo kein Frühling 
ist, kein Sommer und kein Winter, sondern wo das ganze Jahr hindurch ein fauliger und feuchter Herbst sein Wesen treibt und bald den Frühling, bald den Winter parodiert....]

Letzteres ist auch eine Anspielung auf Puškins "Evgenij Onegin": "Aber unser nördlicher Sommer ist nur eine Karikatur der Winter im süden ...".

Dieses Petersburg, das Belinskij hier im Sinne der sogenannten "physiologischen Richtung" der 40er Jahre schildert, kennen wir auch als das Petersburg Dostoevskijs aus den "Bednye ljudi" [Armen Leuten], dem "Dvojnik" [Doppelgänger], aus Dostoevskijs Feuilletons und aus dem späteren Raskol'nikov-Roman, wo Dostoevskij Symbole wie Nebel, nassen Schnee, schwïle Hitze, ungesunde Ausdïnstungen in die Handlung einbaut. Petersburg ist, wie Dostoevskij nicht müde wird zu wiederholen, eine absurde Stadt, ein Fieberherd, eine Brutstätte für fixe Ideen und Halluzinationen. Petersburg ist selbst etwas Unwirkliches und Abstraktes, die ganze Stadt könnte, wie Dostoevskij im "Podrostok" [Jüngling] .eine Stimme sager läßt, sehr wohl eines Tages "spurlos wieder verschwinden", sie ist nur eine "Traumvision".

Auch das ist aufschlußreich, daß Dostoevskij Petersburg eine "charakterlose" Stadt genannt hat. Im "Dnevnik pisatelja" [Tagebuch eines Schriftstellers] spricht er davon, daß $\mathrm{Pe}-$ tersburg dauernd im Umbau begriffen sei. Die Häuser ändern ihre Fassaden, entsprechend der jeweiligen Mode, und da bricht es aus Dostoevskij hervor:

"Да и вообще архитектура всего Петербурга чрезвычайно характеристична и оригинальна и всегда порахала меня, - именно тем, что вырахает всю его бесхарактерность и безличность за все время существования. Характерного в положительном смысле, своего собственного, в нем разве только вот зти деревянные, гнилые домишки, еще 
уцелевшие дахе на самых блестящих улицах, рядом с громаднейшими домами, и вдруг порахающие ваш взгляд словно куча дров возле мраморного палаццо...

Что, не приходило вам в голову, что в Петербурге угрюмые улицы? Мне кахется, что самый угрюмый город, какой только мохет быть на свете!"

[Und überhaupt, die Architektur von ganz Petersburg ist äuBerst charakteristisch und originell und hat mich immer frappiert, - gerade dadurch, daB sie die ganze Charakterlosigkeit und Unpersönlichkeit dieser Stadt ausdrückt, vom Beginn ihres Bestehens an. Charakteristisch im positiven und eigentlichen Sinn sind hier höchstens diese hölzernen, dahinfaulenden Häuschen, die sogar noch in den glânzendsten Straßen übrig geblieben sind, neben ganz riesenhaften Bauwerken, und sie fessein den Blick plötzlich wie ein Haufen Brennholz neben einem Palazzo aus Marmor ... Ist Ihnen nie der Gedanke gekommen, daß die Petersburger Straßen düster sind? Mir will scheinen, daß Petersburg die düsterste Stadt ist, die überhaupt auf der Welt existieren kann.]

Es blieb den russischen Symbolisten vorbehalten, die Einheit von Romantik, magischem Realismus und physiologischem Naturalismus herzustellen. Die Petersburger Literaturepoche kulminiert im Symbolismus, und nicht zufällig weiß sich der Symbolismus Puškin so gut verpflichtet wie Gogol', der "physiologischen" Richtung so gut wie Dostoevskij.

Von allergröBter Wichtigkeit ist da für unser Thema ein Roman, der symbolistische Roman "Peterburg" [Petersburg] von Andrej Belyj, erstmalig zum Druck befördert 1913. Petersburg spielt hier nicht nur die Rolle eines fast schon unwirklichen Schauplatzes, sondern es ist auch das Symbol schlechthin, Symbol einer Auflösung, Symbol eines geschichtlichen Kehraus. Die Hauptstadt Petersburg, in der die Fäden einer beängstigend verworrenen Fabel sich immer wieder verlieren, existiert nur noch als halluzinatorisches Bewußtsein der 
wie Schlafwandler handelnden und leidenden Figuren. Die extreme Verdichtung der Zeit, die ihr Gleichnis in dem Uhrwerk der Höllenmaschine, d.h. ir dem Werkzeug eines exakt vorbereiteten Attentats findet, erscheint historisch gesehen wie die Stauung des Bewußtseins vor jener historischen Explosion, deren Deuter und Prophet Andrej Belyj lange vor der Oktoberrevolution gewesen ist. Petersburg selbst, einst das Zentrum der russischen imperialen Kultur, wird in ungewöhnliche geometrische und architektonische Teilansichten aufgesplittert, so als erlebe die Stadt bereits ihren Höllensturz in das Nichts:

"За Невой, в потусветной, зеленой там дали -
повосстали призраки островов и домов, обольщая
тщетной надеждою, что тот край есть действитель-
ность, и что он- не воющая бескрайность, которая
выгоняет на петербургскую улицу бледный дым облаков."

[Hinter der Neva, dort in der halb erhellter, grünen Ferne standen die Schattenrisse von Inseln und Häusern, um die trügerische Hoffnung zu erwecken, diese Gegend sei Wirklichkeit, sei nicht jammernde Endlosigkeit, die den fahlen Qualm cer Wolken durch die Petersburger Straßen blies.]

"Petersblirg" ist ein mythologischer Roman, insofern als sich das GeschichtsbewuBtsein und daher auch die Interpretation der mussischen Geschichte bei den Symbolisten zu ganz bestimmten Mythen verfestigte. Genau betrachtet weisen diese Mythen aber fast immer auf die russische literarische Tradition zurück, von der sich auch der Symbolismus getragen wußte. Wenn Belyj mitten im Roman auf einmal auf den "Ietuxij Gollandec" [Fliegenden Holländer] zu sprechen kommt, dann sehen wir dahinter natürlich Peter den Großen, den Gründer der fatalen Stadt, der bei Eelyj eben jene Rolle spielt, an die 
Puškin als erster erinnert hatte:

"А там были - линии: Нева, острова. Верно, в те далекие дни, как вставали из мшистых болот и высокие крыши, и мачты, и шпицы, проницая зубцами своими промозглый, зеленоватый туман, -

на теневых своих парусах полетел к Петербургу Летучий Голландец из свинцовых пространств балтийских и немецких морей, чтобы здесь воздвинуть обманом свои туманные земли, и назвать островами волну набегаюих облаков."

[Und da waren - Linien: die Neva, die Inseln. GewiB war in jenen fernen Tagen, als hohe Dächer, Masten und Turmspitzen aus den moosbedeckten Sümpfen aufragten und mit ihren Zacken den modrigen, grünlichen Nebel durchstießen, der Fliegende Holländer auf seinen Schattensegeln aus den bleigrauen Weiten der Nord- und Ostsee nach Petersburg geflogen, um hier sein trügerisches Nebelreich zu gründen und diese wogenden Wolkenmassen Inseln zu nennen.]

Die Wirklichkeit ist in Belyjs Petersburg absichtlich auf den Kopf gestellt, es wimmelt von geometrischen Symbolen, von spiegelverkehrten Räumen, Astralleibern, bloßen Schatten. Petersburg, so heiBt es bei Belyj an einer Stelle des Romans, gehört der vierten Dimension an, auch wenn diese auf der Landkarte zu einem bloßen Punkt schrumpft:

"Точка же - место касания плоскости бытия к шаровой
поверхности и громадного астрального космоса - точка
во мгновение ока способна нам выкинть жителя чет-
вертого измерения, от которого не спасет и стена...

[Der Punkt aber ist die Berührungsstelle der Ebene des Seins mit der Kugeloberfläche und des ungeheuren astralen Kosmos; der Punkt ist fähig, im Handumdrehen den Bewohner der vierten Dimension hervorzubringen, vor dem auch keine Mauer retten kann.] 
In Belyjs "Petersburg" ist die Provokation am Werk, von dem Dichter ebensowohl als astrale Provokation gedeutet wie als politische Provokation. Insofern ist "Petersburg" auch ein politischer Roman, obwohl Belyjs Ambitionen sehr viel weiter gehen, als etwa einen politischen Schlüsselroman zu schreiben. Petersburg ist für Belyj ein Mythos, aber diesem Mythos wachsen im historischen und im politischen Raum gewisse Verbindlichkeiten zu. Wie sollte man die Warnung vor den Schatten anders verstehen als die Warnung vor einer auch real drohenden Revolution? Aus diesen Schatten wachsen unversehens Provokateure und Attentäter auf, auch oder gerade wenn Belyj den Schauplatz scheinbar in mythische Ferne, ja in die Unterwelt verlegt:

"О, русские люди, русские люди! Вы толпу скользящих теней с островов к себе не пускайте! Бойтесь островитян! Они имеют право свободно селиться в Империи: знать для этого чрез летийские воды к островам перекинуты черные и серые мосты. Разобрать бы их... Поздно..."

[0 russische Menschen, mussische Menschen! LaBt die Scharen gleitender Schatten von den Inseln nicht $z u$ euch! Fürchtet euch vor den Insulanern! Sie haben das Recht, sich im Imperium frei niederzulassen: offenbar zu diesem Zweck sind über den Strom Lethe schwarze und graue Brücken geschlagen. Entfernen müßte man sie ... Zu spät ... ]

Ubertragen auf die Petersburger Geographie sind das die Inseln jenseits der Neva, die bevorzugten Wohnquartiere der intellektuellen Boheme, Petersburgs "Quartier latin", was insofern für Belyj bezeichnend ist, als er die Revolution als eine geistige Provokation auffaBte.

Einer dieser Provokateure im Roman ist ein geheimnisvoller Perser, dessen Name mehrfach auch als Anagrammim Roman auftaucht, als eine Art Zauberwort, und es ist von der russi- 
schen Kritik selbst darauf hingewiesen worden, daB Belyj hier an den Philosophen Vladimir Solov'ev gedacht haben dürfte und an den Kampf, von dem dieser spricht: den Kampf zwischen dem Osten Christi und dem Osten des Xerxes, der Rußland sufgetragen ist.

Man sieht an solch einer Einzelheit, welche vielfältigen geschichtsphilosophischen Aspekte Belyj hier verfolgte.

Es kann uns jetzt auch nicht mehr verwundern, wenn wir in dem Roman der lebendigen Statue Peters des GroBen wiederbegegnen, in einer grotesken Travestie des "Ehernen Reiters" von Puškin.

Dem Werkzeug der Terroristen, Alexander Dudkin, der im Roman als auserwählter Vollstrecker des Unabwendbaren erscheint, tritt der Zar entgegen:
"Посередине дверного порога, из стен, пропускающих купоросного цвета пространства, - склонивши венчанную, позеленевшую голову и простирая тяжелую позеленевшую руку, стояло громадное тело, горящее фосфором. Встал Медный Всадник."
[Mitten auf der Türschwelle, neben wänden, die kupfervitriolfarbene Räume bereinließen, stand ein riesiger wie Phosphor brennender Körper, den gekrönten, grünlich.gefärbten Bronzekopf gesenkt, und den schweren grünlich gefärbten Arm vorgestreckt. Da stand der Eherne Feiter.]

Der Eherne Reiter in der Dachkammer des Petersburger Inselbevohners in der Dachkammer des intellektuellen Terroristen rom Vasil'evskij Ostrov!

Wie haben sich die Rollen ausgeglichen! Für Belyj ist Peter der Große derjenige, dessen Testament die Revolution ist.

Zuerst einmal macht es sich Jas Derikmal in der Dachkammer gemütlich: 
"И бряцая, и дзанкая, до красна раскаленную трубочку повынимала рука; и - указывала глазами на трубочку; и - подмигнула на трубочку: 'Petro Primo Catherina Secunda'... 1)

Всунула в губы: зеленый дымок распаявшейся меди отчетливо закурился под месяцем.

Александр Иванович, Евгений, впервые тут понял: столетие пробежал понапрасну: от декабря к октябрю: а 3 а ним громыхало без всякого гнева - по деревням, городам, по подъездам, по лестницам; он прощенный..."

[Klirrend und klimpernd $z \circ g$ die Hand eine rotglühende Pfeife heraus; und mit den Augen deutete sie auf die Pfeife; und sie zwinkerte mit den Augen in Richtiuns auf die Pfeife: Petro Primo Catherina Secunda... Sie schob die Pfeife zwischen die Lippen, und der dünne, grüne Rauch schmelzenden Kupfermetalls ringelte sich deutlich im Mond?icht. Da begriff Aleksandr Ivanovič, Evgenij, zum ersten Mal, daß er ohne jede Not ein ganzes Jahrhundert hindurch gelaufen war - vom Dezember bis zum Oktober uni daß die donnernden Schläge ihn ohne jeden Zorn durch Dörfer, Städte, Hauseingänge, treppauf und treppab verfolgt hatten; inm war verziehen ....]

Damit deutet sich in Belyjs Roman der Gedanke an, daß Peter mit der revolutionären Intelligenz Frieden geschlossen hat: en ist selbst einer der ihren, ja mehr noch: er selbst ist die Provokation.

Der Schlußsatz, mit dem BelJj die groteske Traumszenerie in eine physische Sensation einmünden läßt, enthält den Beweis:

"Металлический Гость, раскалившийся под луною, сидел перед ним; опаляющий, краснобагровый; вот он, прокалясь, побелел; и - протек на склоненного Александра Ивановича: пепелящим потоком: метеллами - пролился в его жилы."

1) Diese "ehernen" Worte geben die Widmungsinschrift Katharinas II. auf dem Sockil des Denkmals wieder. 
[Im Mondschein glühend $s a B$ der metallene Gast vor ihm, sengend, purpurrot; schon aber geriet er in Weißglut; er floB auf den gebeugten Aleksandr Ivanovič zu - ein sengender Metallstrom: als Metall flob er in seine Adern.]

Der Roman, auf den ich hier eingegangen bin, zeigt wohl am besten, wie sich der Bogen über ein knappes Jahrhundert hinweg spannt, und welche ominöse Rolle Petersburg in der russischen Literatur dieses Zeitraumes spielt. Das Gesagte ließe sich an sehr viel anderen Beispielen noch näher illustrieren, aus der Lyrik etwa, oder aus der essayistischen Prosa. Ich habe Ihnen zu Beginn mit Merežkovskij ja schon einen Eindruck davon gegeben, und gerade Merežkovskij gehörte zum engsten Kreis der russischen Symbolisten. Und er war es ja auch, der Peter den Großen als den "ersten russischen Intellektuellen" bezeichnet hat. Damit meinte Merežkovskij offensichtlich etwas Destruktives, und mir scheint das für die Beurteilung russischer Verhältnisse nicht ganz unwichtig zu sein. Rußland hatte auch sein Intelligenzproblem, und es hat den Anschein, als habe dieses Problem etwas mit dem Leiden an der Hauptstadt Petersburg zu tun. Die russische Seele - ich muß diesen verpönten Begriff einmal gebrauchen - ist mitPetersburg und seinem geistigen Hintergrund niemals richtig fertig geworden, und es erscheint von daher nicht einmal sehr überraschend, daß die Räteregierung (Sowjetregierung) nichts Eiligeres $z u$ tun hatte, als den Sitz der zentralen Administration wieder nach Moskau zu verlegen.

Mit dem Symbolismus endet der Petersburger Zyklus der russischen Literatur, in der Sowjetliteratur spielt Petersburg - seit 1924 Leningrad - keine ganz vergleichbare Rolle mehr. 
Gleichwohl gibt es zwischen 1917 und I922 noch einen Nachhall, die neoklassizistische Dichtung der Akmeisten und einiger Einzelgänger wie z.B. des Lyrikers, Puškinexegeten und Essayisten Vladislav Chodasevič.

Man denke nur an Osip Mandel'štam während des 1. Weltkrieges, denn gerade bei ihm verwandelt sich Petrograd wieder in das klassizistische Petropolis, unter strenger Bewahrung der neu hinzugekommenen mythischen Verklammerungen. Lassen Sie mich nur ein Gedicht zitieren:

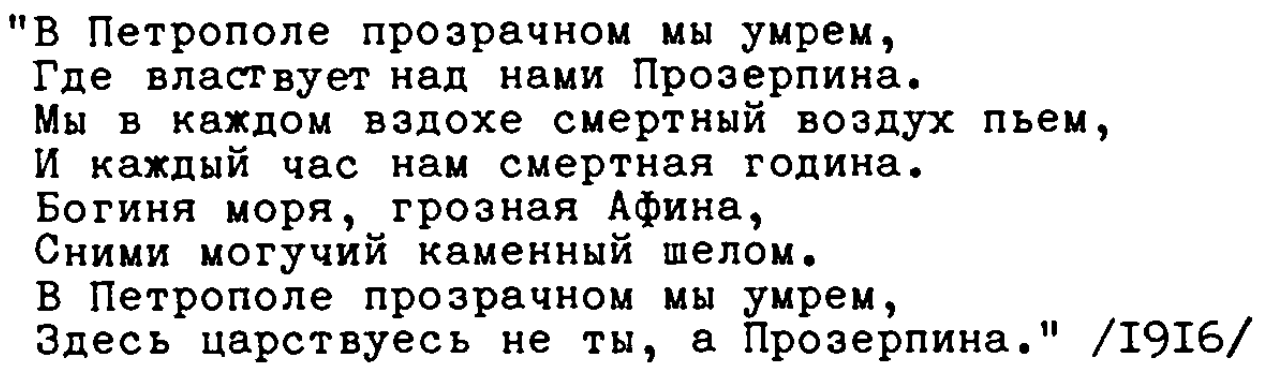

Die Verse lauten nach der tbersetzung von Paul Celan: "Petropolis, diaphan: hier gehen wir zugrunde,
hier herrscht sie über uns: Proserpina.
Sooft die Uhr schlägt, schlät die Todesstunde,
Wir trinken Tod aus jedem lufthauch da.
Den Helm, den steinernen, jetzt losgebunden,
Athene, meerisch. Mächtig, schreckensnah!
Petropolis, diaphan: hier gehen wir zugrunde,
nicht du regierst - hier herrscht Proserpina." Mandel'štams Petersburgist durchsichtig wie das Antlitz eines Kranken, und doch ist im Neoklassizismus und im Akmeismus eine ganz neue Einstellung zu beobachten: das Pathos ist antiromantisch und antisymbolistisch, die Dichter, die vor der kulturellen Gleichschaltung im sowjetischen Petersburg noch wie auf einer Insel lebten, blieben sich der Tradition auch des I8. und des frühen 19. Jhdts. bewaßt. Sie empfinden Abschiedsschmerz um Petersburg, aber das Petersburg, dem ihre wehmütige Erinnerung gilt, ist nicht so sehr das Petersburg 
Dostoevskijs oder Andrej Belyjs, wie vielmehr die Stadt des "russischen Empire", die Stadt der Musen und der Wissenscheften. So beginnt ein Gedicht Mandel'štams aus dem November 1920:

"В Петербурге мы сойдемся снова, Словно солнце мы похоронили в нем, И блахенное, бессмысленное слово

В первый раз произнесем."

[In Petersburg müssen wir wieder zusammenkommen; ist es nicht so, als hätten wir die Sonne zu Grabe getragen

und als sollten wir hier das selige Wort ohne Sinn zum ersten Mal aussprechen.]

Anna Achmatova, die zu dem gleichen Kreis der Akmeistea gehörte, hat in einer ihrer späten Dichtungen, während des letzten Krieges im belagerten Leningrad, dieses Gedicht Mandel'štams als Motto benutzt. Ihre Dichtung heißt "Poem ohne Helden" [Poèma bez geroja], und das mit Recht, denn der einzige Held ist das historische Petersburg, an das sich diz Dichterin nun wieder erinnert, da die Deutschen in Sichtweite der Stadt liegen:

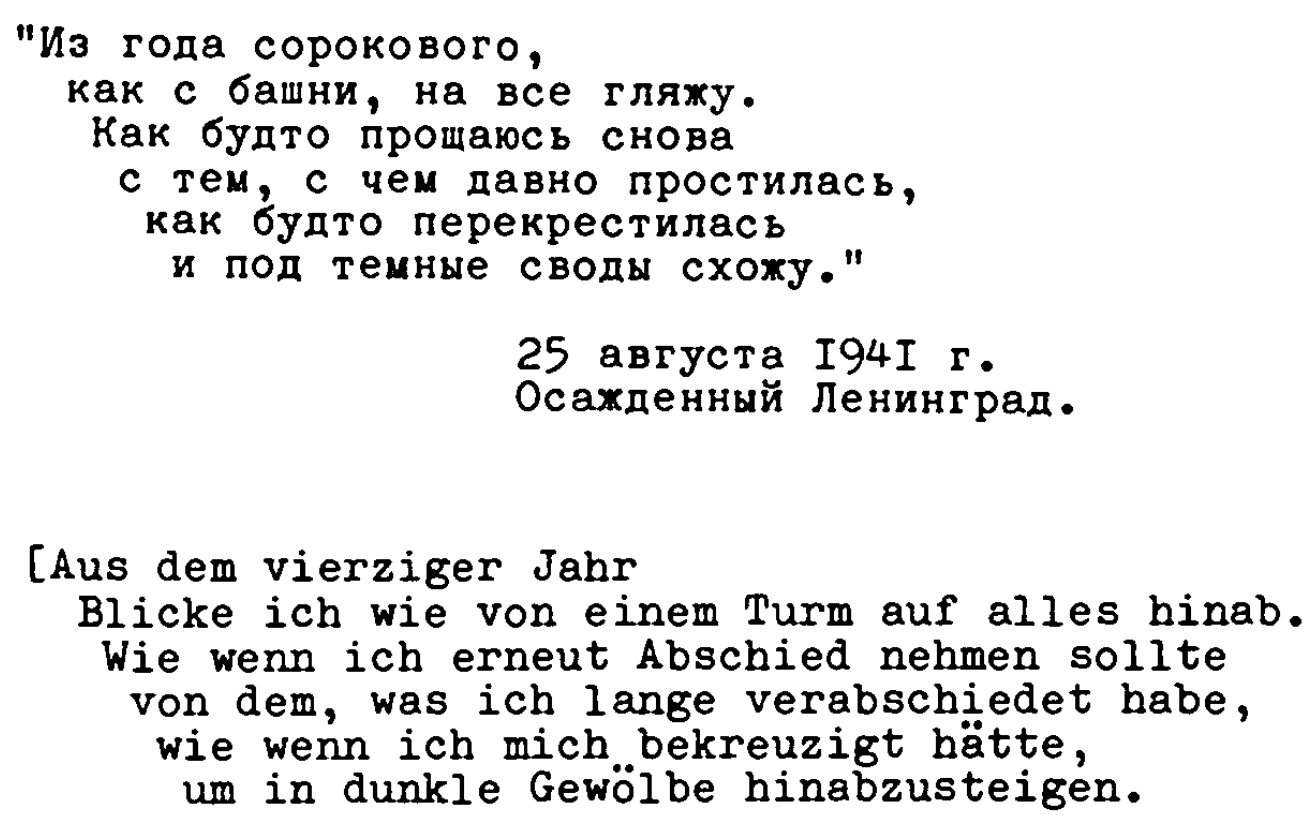

[Aus dem vierziger Jahr Blicke ich wie von einem Turm auf alles hinab. Wie wenn ich erneut Abschied nehmen sollte von dem, was ich lange verabschiedet habe, wie wenn ich mich bekreuzigt hätte, um in dunkle Gewölbe hinabzusteigen. 25. August 1941 Im belagerten Leningrad]

Das historische Petersburg des ersten Teils ist im letzten Teil des Poems ohne Helden verdrängt durch das schwer 
leidende und in den letzten Zügen liegende Leningrad der

Kriegsjahre. Von ihrem Evakuierungsziel Taškent aus wendet sich Anna Achmatova im Epilog noch einmal an ihre geliebte Stadt, aus der sie nun weichen mußte:

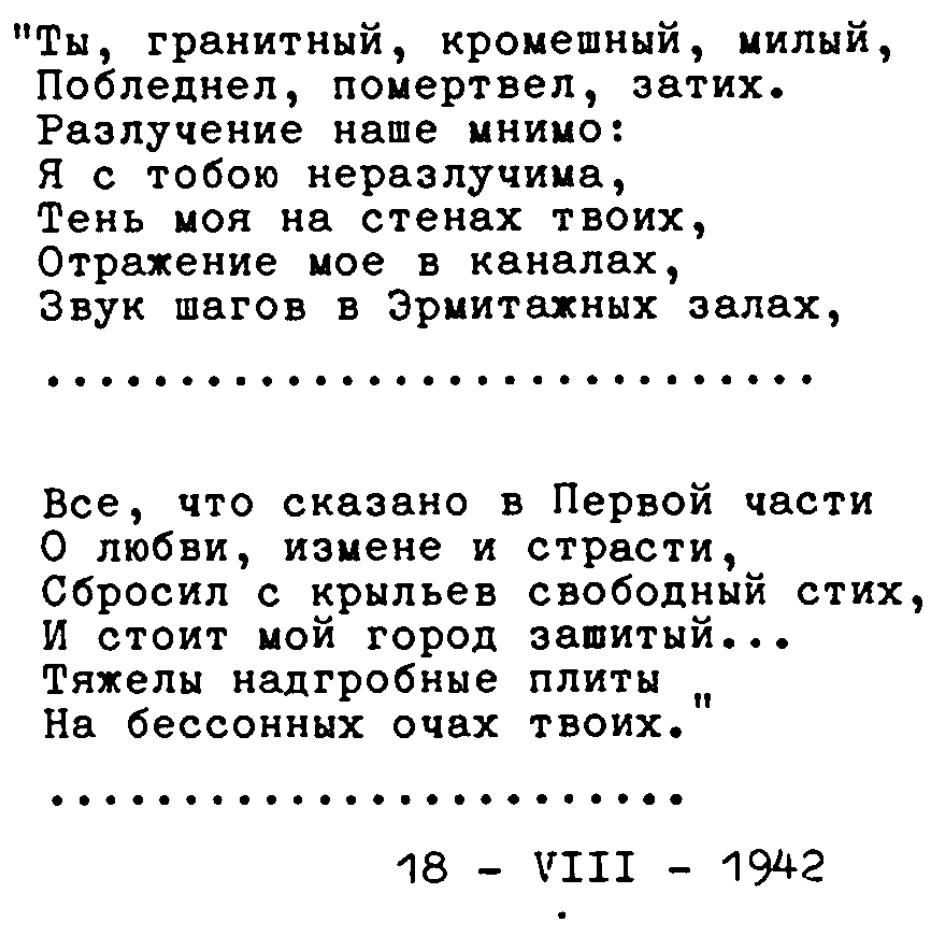

[Du, aus Granit, verzweifelte, geliebte, Erbiaßt, gestorben, verstummt. Unsere Trennung ist nur Schein: Unlösbar bin ich mit dir. Mein Schatten ist auf deinen Wänden, Meine Spiegelung in den Kanälen, Das Hallen meiner Schritte in den Sälen der Eremitage,

Alles, was im Ersten Teil gesagt ist, über Liebe, über Verrat und Leidenschaft, Hat der freie Vers von seinen Flügeln gestreift Und es steht meine Stadt, eingenäht ... Schwer sind die Grabesplatten auf deinen schlaflosen Augen. [.............................. [18.8.1942]

Wir sind am Ende angelangt, und ich bin mir darüber im klaren, daB vieles Andeutung bleiben muBte. Das Problem ist im Grunde noch viel weiter verzweigt, aber ich glaube doch, daß ich habe zeigen können, daß Petersburg eines der großen zentralen Themen der russischen Literatur ist und daB man von 
hier aus eine Ahnung davon gewinnen kann, welche geistigen Spannungen RuBland aus seiner Vergangenheit ererbt hat.

L i t e r a t u r a 8 a b e n

A c h m a $t \circ v$ a, A.: Sočinenija. Bd. 2, 0.0. 1968.

B e $l$ i n s $k$ i j, V. G.: Peterburg i Moskva. In: V.G. Belinskij: Sobranie sočinenij $v$ trech tomach. T.2, Moskva 1948.

B e 1 y.j, A.: Peterburg. Roman v vos'mi glavach s prologom i épilogom. (Nachdruck der Ausgabe Petrograd 1916). Letchworth, Hertfordshire 1967.

B e 1 y j, A.: Peterburg. Roman. I-II. Epocha. Berlin 1922.

B r ju s o v, V.: Mednyj vsadnik (1909). (In: V. Brjusov: Izbrannye sočinenija v druch tomach. T.2, Moskva 1955.)

C e 1 a n, P.: Drei russische Dichter. Alexander Block, Ossip Mandelstamm, Sergej Jessenin. Ubertragen von Paul Celan. Frankfurt/M. 1963. (Fischer-Bücherei. 510.)

D o s $t \circ$ e v s k $i$ j, F. M.: Dnevnik pisatelja za 1873 god. Paris o.J.

G $\circ$ g $\circ I^{\prime}, N_{.}$V.: Peterburgskie zapiski 1836 goda. In: N.V. Gogol': Polnoe sobranie sočinenij. T.8, Leningrad 1952.

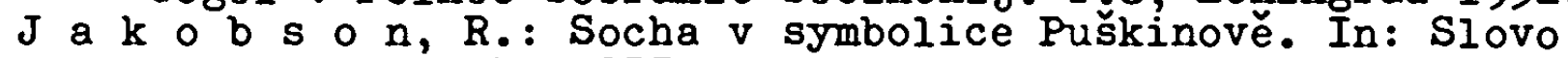
a slovesnost $3,1937$.

L e d n $i c k i$, W.: Pushkin's Bronze Horseman. The Story of a Masterpiece. Berkeley and Los Angeles 21955.

$M$ a n d e l'š t a $m$, 0. : Sobranie sočinenij $v$ dvuch tomach. T.1 Washington 1964 .

$M e r e^{2} \mathrm{k} \circ \mathrm{v} \mathrm{s}_{i} \mathrm{j}_{\text {, }}$.: Zimnie radugi. In: D. Merežkovskij: Polnoe sobranie sočinenij. T.15, Moskva 1914.

P u š k i n, A. S.: Mednyj vsadnik. In: A.S. Puškin: Polnoe sobranie sočinenij. T.5, Moskva 1948.

S $\circ 1$ l 1 g u b, V. A.: Tarantas. Putevye vpečatlenija. Moskva 1955.

S u m a $r \circ k \circ v, A$. P.: Izbrannye proizvedenija. Leningrad 1957. 


\section{Gogol'und die GroBstadt}

Gogol' als den Dichter der Großstadt zu apostrophieren, könnte demjenigen zunächst als ein etwas ungewöhnlicher Annäherungsweg erscheinen, der Gogol' vor allem als den Dichter der "Toten Seelen" verehrt oder als den Schöpfer der Kleinstadtkomödie vom falschen Revisor.

Gogol's Spektrum ist aber, was die Wahl seiner Themen angeht, von einer solchen Breite, daß sich sehr wohl der Geschmack am Althergebracht-Provinziellen mit dem Geschmack am Weltläufig-Zukunftsverheißenden vereinigen läBt.

Der scharfe Blick, den Gogol' für die Eigenart und für das Eigenleben der russischen Provinz in den "Toten Seelen" verrät, hat ihn viel früher schon die damals noch verhüllte Physiognomie der Großstadt als ein modernes Phänomen erkennen lassen.

Gogol' hat von 1829-1836 mit kürzeren oder längeren Unterbrechungen in Petersburg gelebt, in der ersten Großstadt des russischen Reiches, die diesen Namen verdient, der Stadt, die durch ihre künstliche Randlage und durch ihr fast sagenhaftes Wachstum im sumpfigen Inseldelta des Nevaflusses schon um 1830 manche den Russen fremde Züge angenommen hatte. In den ausgehenden zwanziger und dreiBiger Jahren des 19. Jahrhunderts wird Petersburg in der russischen Literatur häufig Moskau entgegengestellt und mit Akzenten versehen, die deutlich machen, daß Petersburg im Gefühl der Zeitgenossen die dynamischen, in die Zukunft weisenden Entwicklungstendenzen des urbanen Lebens verkörperte. Im "Ehernen Reiter", der 
letzten Verserzählung, die Puškin 1833 geschrieben hat, heiBt es in der berühmten Einleitung:

"И перед младшею столицей
Померкла старая Москва,
Как перед новою царицей
Порфироносная вдова."

[Vor der jüngeren Hauptstadt ist das alte Moskau verblaBt/wie vor der neuen Herrscherin/die purpurtragende Witwe.]

Petersburg wird zum "nördlichen Palmyra" proklamiert, aber hinter dieser Schauseite, hinter den aus dem Boden wachsenden Xmtern und Palästen wächst zugleich ein thel, das der von Aleksandr Blok so geschätzte Dichter Apollon Grigor'ev in den vierziger Jahres des 19. Jahrhunderts in seinem Gedicht "Gorod" [Die Stadt] als Inbegriff Petersburgs sehen wollte:

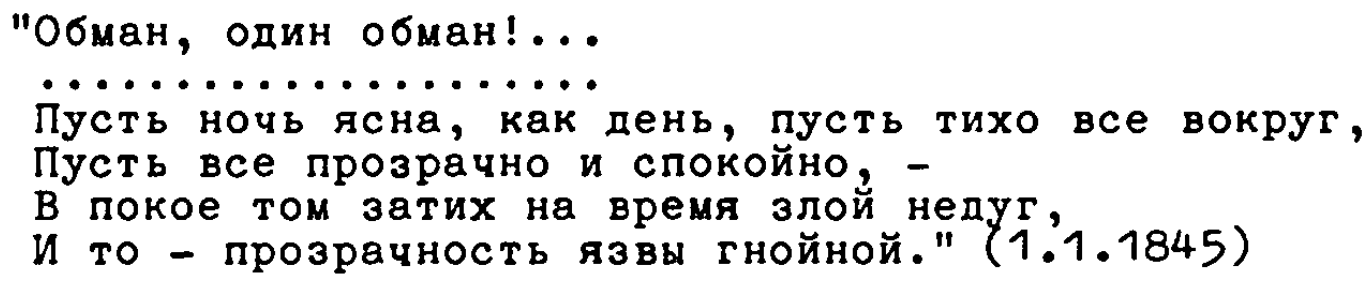

[Trug, alles Trug/.../Mögen die Nächte hell sein wie der Tag, mag ringsherum alles still sein,/mag alles durchsichtig und ruhig sein,/in dieser Ruhe ist das schlimme tbel vorübergehend zum Schweigen gebracht:/ das ist nur die Durchsichtigkeit einer Eiterbeule.]

Derselbe Apollon Grigor'ev war zu seiner Zeit auch ein viele andere überragender Literaturkritiker, und er hat einmal gesagt:

"Но определительно и ярко сознать ту односторонность жизни которую представлял Петербург 30-x 40-x годов - дано было только Гоголю."

[Nur Gogol' war es gegeben, bestimmt und klar jene Einseitigkeit des Lebens zu erfassen, die Petersburg in den dreißiger und vierziger Jahren verkörperte.] 
Als Gogol' zwanzigjährig nach Petersburg kam, hatte er allerdings zunächst einen ganz anderen Themenkreis im Auge, der eng mit seiner südrussisch ukrainischen Heimat verknüpft war: Anekdotisches aus Kleinrußland, Volksglaube und Volksaberglaube, die märchenhafte Romantik einer von Petersburg her gesehen fast schon orientalischen Provinz, die damals literarisch gerade in Mode gekommen war. Die "Večera na chutore bliz Dikan'ki" [Abende auf dem Vorwerk bei Dikan'ka] und der spätere Zyklus "Mirgorod" lassen vielfältige Reflexe dieser frühen Neigung erkennen. Aber zugleich verfolgte Gogol' aufmerksam, was oft von weit her an literarischen Neuheiten nach Petersburg hereinkam. Neben die vorwiegend deutschen und englischen literarischen Einflüsse, die in Gogol's frühen romantischen Erzählungen zu vermerken sind (Tieck, Wackenroder, E.T.A. Hoffmann, Scott, Byron), treten in der Folgezeit verstärkt Einflüsse aus Frankreich. Im Herbst 1832 sammelt sich um Gogol' ein literarisch und künstlerisch interessierter Kreis ehemaliger Schulkameraden aus dem Gymnasium in Nežin, und Pavel Annenkov, der Gogol' um diese Zeit kennerlernte, berichtet in seinen Memoiren, daß Gogol' für alle seine Freunde besondere Decknamen verwandte, Namen neuester französischer Schriftsteller: Victor Hugo, Alexandre Dumas, Balzac, Jules Janin usf. Es ist daher kaum zweifelhaft, daß Gogol' zu seinen sogenannten Petersburger Novellen zum Teil durch französische Vorbilder angeregt wurde. Balzac kam damals in Rußland gerade sehr in Mode, schor in Puškins späten Prosaerzählungen zeigen sich flüchtige Anklänge an Balzac, und auch Gogol' verwendet gewisse Stimmungen, die von Balzac entlehnt sind. Paris ist ja überhaupt der Ursprungsort der Großstadtdichtung des 19. Jahrhunderts, zwi- 
schen 1831 und 1833 entsteht Balzacs "Histoire des Treize" mit dem Untertitel "Scènes de la vie parisienne" und etwa um diese Zeit erscheint in Paris der erste Band eines eigenartigen Sammelwerkes mit dem Titel: "Le livre des Cent-et-Un". In ihm kommt ein großes Aufgebot von verschiedenen Autoren zu Wort, und es wird eine Art Panorama des Pariser Lebens entrollt. Das Werk hatte ursprünglich den Titel "Le diable boiteux à Paris" tragen sollen, in Anspielung an den damals populären hinkenden Teufel bei Lesage, der sozusagen zu Studienzwecken die Dächer der Häuser abhebt und so immer neue Schicksale aufrollt. Zum"Livre des Cent-et-Un"hat sogar noch der greise Goethe eine kurze Rezension geschrieben, in der $\leqslant r$ auf den eigentümlichen Etagencharakter, d.h. guf die miIieugebundene Schichtung der Stoffe hinweist:

"In dem jetzigen Paris wäre wenig geleistet, wenn man nur die Dächer abheben und in die oberen Schlafkammern hineinblicken wollte. Unsern Mitarbeitern sind die Festsäle der Großen zugänglich wie die Jammergewölbe der Gefängnisse. Der zurückgezogenste Mietmann ist ihnen so wert als der begüntigte Dichter ... Die mannigfaltigsten Denkweisen und Gefühlarten mitteilend, gewinnen sie uns für Interessen, welche nicht die unsrigen sind".

Goethe hat also auf diese Weise noch den Beginn der modernen Großstadtdichtung erlebt.

Das besondere Interesse, das sich in RuBland nach 1830 so plötzlich der Großstadt zuwandte, und durch das ein ganz neuer Typ des literarischen Helden auf den Schild gehoben wurde, hatte allerdings noch andere Wurzeln. Um die Wende der zwanziger und dreißiger Jahre hatte sich auch der Journalismus in Rußland immer mehr auf das Großstadtleben ein- 
gestellt. Die Gattung des "feuilleton de moeurs", des Sittenfeuilletons also, hatte sich - wiederum von Frankreich angeregt - der Vielfalt des täglich wechselnden Lebens in der Stadt angenommen. Wie der schwedische Slavist Nils Ake Nilsson in einer ausführlichen Studie über Gogol's Petersburger Erzäblungen zeigen konnte, hat der französische Feuilletonismus, z.T. über den Umweg der russischen Nachahmer, Wirkungen auf Gogol's Großstadterzählungen gehabt. Ganz zweifellos hat auch eine belletristische Kollektivarbeit wie der "Livre des Cent-et-Un", von dem Goethe so nachhaltig beeindruckt war, seinen Vorläufer im skizzenhaften Feuilleton, das in anekdotischer Einkleidung jeweils ein typisches Panorama hervortreten läBt. In diesen Panoramen zeigt sich die Stadt schlieBlich als eine richtige Landschaft, als eine Art Idylle mit umgekehrtem Vorzeichen. Der Lustort, der alte locus amoenus, wird zum locus obscurus, zum finsteren, lichtlosen Gefängris, das E.A. Poe kannte, das später Dostoevskij in seinen Romanen so oft zum Schauplatz der dramatischen Handlung gemacht hat. Bestimmte Aspekte dieser Landschaft können auf das'feuilleton de moeurs"und die sich daran unmittelbar anschließende "panoramatische" Literatur zurückgeführt werden: da ist einmal die Technik der Wechselbilder, d.h. die Schilderung einer Straße oder eines einzelnen Hauses im Wechsel der Tageszeiten, dann der AufriB der Großstadtbilder in Stockwerken, d.h. eine Reportage der Lebensvorgänge vom Keller bis zum Dachboden, durch alle sozialen Schichtungen hindurch, weiter die künstliche Landschaft der Schaufenster, der Läden überhaupt, der Innenraum der "Passagen", der Höfe und Treppenhäuser, die Ameisengänge dèr Brücken் und Hauptverkehrsadern. Die Literatur entwickelt zum ersten Mal eine Physiognomik der Menge, 
zugleich aber auch eine Physiognomik des Interieurs; denn das Menschenbild polarisiert sich auf eine unheilvolle Weise: auf der einen Seite steht die anonyme, gesichtslose Menge, auf der anderen Seite der gestrandete Einzelmensch, der mehr und mehr die Züge eines asozialen Wesens annimmt. Und der Dichter selbst taucht in dieser Menge unter, verwandelt sich in einen gespannten Beobachter, einen Flâneur, wie er sich selbst gern nennt, und liest sich seine Modelle sozusagen direkt von der Straße auf.

Der Typus dieses Beobachters läßt sich durch die ganze spätromantische und nachromantische Literatur des 19. Jahrhunderts verfolgen: von den ersten modernen Feuilletonisten bis zu E.A. Poe, zu Dostoevskij, zu Baudelaire oder zu Barbey d'Aurevillys "Diaboliques". Walter Benjamin hat in den Entwürfen zu seinem geplanten Buch "Paris, die Hauptstadt des XIX. Jahrhunderts" über diesen Flâneur gesagt:

"Er sucht sich sein Asyl in der Menge ... Die Menge ist der Schleier, durch den hindurch dem Flâneur die gewohnte Stadt als Phantasmagorie winkt. In ihr ist sie bald Landschaft, bald Stube."

1832 ist Gogol's Begeisterung für die französische Literatur auf ihrem Höhepunkt, im Herbst 1833 verhandeln Puškin und Vladimir Odoevskij brieflich über ein literarisches Projekt, das sie "trojčatka"nennen, "Almanach in drei Etagen", eine Kollektivarbeit, an der sich Puškin, Odoevskij und Gogol' beteiligen sollten. Der Einfluß der französischen Etagenbilder läßt sich schon an dem Titel ablesen. 1834 erscheint Bašuckijs dreibändiges Werk "Panorama St. Peterburga". 1834 beendet Gogol' seine Novelle "Nevskij prospekt", die in ihrem kompositorischen Aufbau zunächst ungewöhnlich anmutet: 
es werden nacheinander zwei Anekdoten erzählt, deren Helden zwei Passanten des Nevskij Prospekt, der Hauptstraße St. Petersburgs, sind. Nur sehr äuBerlich werden diese beiden Geschichten dadurch verknüpft, daß die beiden Spaziergänger sich gegenseitig kennen und in der Abenddämmerung zu Beginn der Erzählung auf dem Boulevard zusammentreffen. Die Struktur der Novelle beruht auf dem Prinzip des reinen Parallelismus und bietet eine typische panoramatische Szenenfolge, wie sie dem "Livre des Cent-et-Un" entnommen sein könnte, das Goethe "eine Sittenschilderung der Pariser Zustände, Eigenheiten, Verborgenheiten und Offentlichkeiten" genannt hat.

Allerdings ist Gogol's "Nevskij prospekt" weit mehr als eine Sittenschilderung, weil nur gewisse Außerlichkeiten an das "tableau de moeurs" erinnern und weil unter Gogol's dichterischem Blick die Landschaft der Stadt tatsächlich zu einer Phantasmagorie wird. Gerade bei Gogol' zeigt sich vielleicht zum ersten Mal das Bild der toten, seelenlosen Stadt, das in seiner stilistischen Eigenart den Urbanismus des frühen 20. Jahrhunderts vorwegnimmt. Wir werden auf diese Eigenarten gleich zu sprechen kommen, aber wir müssen daran festhalten, daB der Hintergrund der Handlung durch eine für die Zeit typische Panoramenstaffage gebildet wird. Der Titelheld ist ja der Nevskij Prospekt selbst, und er wird gleich zu Anfang im Wechsel der Beleuchtungen, im Wechsel der Tageszeit und der Dekorationen vorgeführt:

"Какая быстрая совершается на нем Фантасмагория в течение одного только дня! Сколько вытерпит он перемен в течение одних суток!"

[Was für eine schnellebige Phantasmagorie vollzieht sich auf ihm im Laufe nur eines einzigen Tages! Wieviele Veränderungen erduldet er im Laufe von nur 24 Stunden!] 
- so leitet Gogol' die eigentliche Schilderung des Nevskij

Prospekt ein, und er setzt vier Mal von neuem an, um die wechselvolle Stimmung auf dem Nevskij Prospekt zu untermalen:

\begin{abstract}
"Начнем с самого раннего утра, когда весь Петербург пахнет горячими, только что выпеченными хлебами и наполнен старухами в изодранных платьях и салопах, совершающими свои наезды на церкви и на сострадательных прохожих."
\end{abstract}

[Beginnen wir am frühen Morgen, wenn ganz Petersburg nach warmem, eben fertig gebackenem Brot riecht, wenn es von alten Weibern in zerlumpten Kleidern und Umhängen wimmelt, die ihre Attacken auf Kirchen und mitleidsvolle Passanten vollführen.]

Das ist der erste Einsatz. Später nimmt Gogol' den Faden wieder auf:

\footnotetext{
"В двенадцать часов на Невский проспект делают набеги гувернеры всех наций с своими питомцами в батистовых воротничках."
}

[Um zwö]f Uhr stürmen den Nevskij Prospekt die Erzieher aller Nationen mit ihren Zöglingen in Battistkrägelchen.]

Und Gogol' schildert in aller Breite, was sich in den Mittagsstunden alles auf dem Boulevard ereignet.

"С четырех часов Невский проспект пуст..."

[Von vier Uhr an liegt der Nevskij Prospekt öde da $\ldots . .$.

heißt es weiter, und schließlich kommt es zum letzten Einsatz :

\footnotetext{
"Но как только сумерки упадут на домы и улицы и будочник, накрывшись рогохею, вскарабкается на лестницу зажигать фонарь, а из низеньких окошек магазинов выглянут те эстампы, которые не смеют показаться среди дня, тогда Невский проспект опять оживает и начинает шевелиться."
}

[Aber sobald nur die Dämmerung. über Häuser und StraBen hereinbricht und der Wächter in ein Haartuch gehüllt die Leiter besteigt, um die Laternen zu entzünden, wenn aus den niedrigen Ladenfenstern 
jene Kupferstiche hervorschauen, die sich nicht ans Tageslicht wagen, dann belebt sich der Nevskij Prospekt wieder und fängt an, sich zu rühren.]

In keiner russischen Erzählung der Zeit wird die Technik der Wechselbilder so anschaulich wie hier bei Gogol' im "Nevskij prospekt". Der Held der ersten tragisch endenden Anekdote ist der Maler Piskarev, der sich fasziniert und willenlos wie eine Kompaßnadel einem - wie ihm scheint - überirdisch schönen jungen weiblichen Wesen an die Fersen heftet, der aber die Entdeckung machen muB, daß sich Traum und Wirklichkeit nicht zur Deckung bringen lassen: das junge Mädchen ist eine gewöhnliche Prostituierte. Von dieser Wahrheit in seinem innersten Streben verletzt, zieht sich Piskarev in das Gehäuse seiner vier Wände zurück, ergibt sich dem einsamen GenuB der Fortsetzung seines Traumes und greift, als der Traum sich schließlich nicht mehr wiederholen will, zum Opium. Auch dies ist bereits ein sehr moderner Zug; denn Piskarev ist in der russischen Literatur der erste, der nun die von Baudelaire gepriesenen "künstlichen Paradiese" kennenlernt, den Rauschzustand nach Opium- oder Haschischgenuß. Noch einmal taucht Piskarev in das verlorene Paradies ein, aber seine Gesundheit hält dieser Kur nicht stand, und in einem Anfall von geistiger Umnachtung schneidet er sich mit einem Rasiermesser die Kehle durch.

Die Entdeckung des Opiums als Quelle künstlerischer Inspiration geht ohne Zweifel auf Thomas de Quinceys 1822 erschienene "Bekenntnisse eines englischen Opiumessers" zurück, über die ein Résumé schon 1827 im "Moskovskij telegraf", dem Moskauer Telegrafen, erschienen war. 1834 wurde das Werk ins Russische übersetzt. In diesen Bekenntnissen des Engländers finden sich ausführliche Schilderungen einer 
Deformierung und Zersetzung der realen Welt, die später gerade aus diesem Grunde Baudelaires Interesse erregten. Hier hat sich der mit Gogol' gleichaltrige Edgar Allan Poe viele Anregungen geholt, genau so wie Gogol' selbst. Baudelaire braucht in seiner Studie über de Quincey an der Stelle, wo er über die "Torturen des Opiums" schreibt, ebenfalls den Ausdruck "poetische Phantasmagorie" und sagt:

"... le sentiment de l'espace et, plus tard, le sentiment de la durée furent singulièrement affectés. Monuments et paysages prirent des formes trop vastes pour ne pas être une douleur pour l'oeil humain. L'espace s'enfla, pour ainsi dire, à l'infini."

Als Symptome eines solchen Rauschzustandes noch unabhängig vom Opiumgenuß müssen auch Piskarevs Empfindungen angesehen werden, als er die Verfolgung der schönen Unbekannten aufnimmt.

"Но дыхание занялось в его груди, все в нем обратилось в неопределенный трепет, все чувства его горели и все перед ним окинулось каким-то туманом. Тротуар несся под ним, кареты со скачущими лошадьми казались недвижимы, мост растягивался и ломался на своей арке, дом стоял крышею вниз, будка валилась к нему навстречу и алебарда часового вместе с золотыми словами вывески и нарисованными ножницами блестела, казалось, на самой реснице его глаз."

[Doch der Atem stockte ihm in der Brust, alles in ihm verwandelte sich in ein unbestimmtes Zittern, alle seine Gefühle brannten, und alles vor ihm hüllte sich in irgendeinen Nebel. Das Trottoir flog unter ihm hin, die Equipagen mit den galoppierenden Pferden schienen wie festgenagelt, die Brucke dehnte sich auseinander und barst in ihrem Bogen, ein Haus stand überkopf, das Wachthäuschen trieb ihm entgegen, und die Hellebarde des Wachtpostens glitzerte, so schien es, zusammen mit der goldenen Schrift eines Ladenschildes, auf dem eine Schere gemalt war, direkt über seinen Augenwimpern.] 
Gogol' hat zu Beginn unseres Jahrhunderts einen sehr aufmerksamen Leser gefunden, und dieser Leser war Andrej Belyj, einer der führenden Vertreter des russischen Symbolismus. Belyjs Werk krönt ein Buch über Gogol', das 1934 erschienen ist, und in diesem Buch hat Belyj die eben zitierte Stelle aus dem "Nevskij prospekt" mit Majakovskij verglichen und betont, daß er Gogol' als den Vorläufer der Urbanisten und Futuristen des 20. Jahrhunderts ansehe. Belyj selbst hat ja, wie oft genug schon betont wurde, in seinem Stil Gogol' bis ins Detail hinein kopiert und viele Kunstgriffe Gogol's in seiner symbolistischen und später beinahe expressionistischen Prosa wiederbelebt.

Daß Gogol's Stil viele Elemente der späteren "Moderne" vorwegnimmt, ist zweifellos richtig, man kann in ihm surrealistische, expressionistische, dekadente und manieristische Züge leicht erkennen. Gogol' hatte eine Vorliebe für das Bizarre und Verschnörkelte, aber auch für das Hyperbolische und Absurde. Derselbe Belyj hat Gogol' einen Vertreter des "asiatischen"Stils in RuBland genannt, und seinen Stil ein Prisma, in dem sich Asien, Homer, Arabien, Barock und Gotik brechen. Nie wird Belyj müde, Gogol's Stil mit Asien, mit dem Aperspektivismus japanischer Malerei, überhaupt mit dem asiatischen Ornamentalismus in Beziehung zu setzen.

Das ornamentale Sehen spielt nun tatsächlich in Gogol's Stil eine bedeutsame Rolle. Gogol' bricht aus der Wirklichkeit einzelne Stücke heraus, die er als freies Ornament, man könnte auch sagen als Etikett für einen bestimmten Bildkomplex eintreten läBt. Mit einem Ausdruck aus der Rhetorik würde man dieses Auswahlprinzip Synekdoche nennen. Mit größtem Eaffinement rückt Gogol' immer ein typisches Ornament in den 
Mittelpunkt seiner Beschreibung, entweder unmittelbar oder auf dem Umweg über einen Vergleich. So heißt es einmal in den "Toten Seelen" (Kap. 2):

"Попадались вытянутые по снурку деревни, постройкою похожие на старые складенные дрова, покрытые серыми крышами с резными деревянными под ними украшениями в виде висячих шитых узорами утиральников."

[Man kam an Dörfern vorüber, die wie auf einer Schnur aufgereiht waren und in ihrer Bauweise alten Holzstapeln glichen. Sie waren mit grauen Dächern gedeckt und mit holzgeschnitzten Zieraten geschmückt, die wie mit Stickmustern versehene Handtücher herabhingen.]

An einer anderen Stelle wieder vergleicht Gogol' geschickt die gedrechselten Säulen eines Vorbaus mit alten Kirchenleuchtern. In diesen Fällen tritt der geschilderte Gegenstand gar nicht ganz ins Bewußtsein ein, er wird sofort durch das viel bildhaftere Ornament verdrängt. Wenn der Hauptmann Kopejkin in den "Toten Seelen" seinen Eindruck von Petersburg schildert, so verfällt er gleich in äuBerste Abstraktion:

"Там шпиц эдакой какой-нибудь в воздухе; мосты там висят эдаким чортом, можете представить себе, без всякого, то есть, прикосновения, - словом, Семирамида, судырь, да и полно!"

[Da erhebt sich eine Turmspitze in die Wolken, und dort, hängen Brücken weiB der Teufel wie, bitte sich vorzustellen, das heiBt ohne jeden Halt, mit einem Wort wie Semiramis, mein Herr, und SchluB damit!]

Im übrigen kann sich der Hauptmann Kopejkin nur noch besonders an ein reiches Haus erinnern, mit einem wahren Wunder von einer Metallklinke an der Tür, und diese Türklinke verdrängt gleich alle anderen Eindrücke: die Klinke ist so sauber, daß man sich im Kramladen zunächst für einen Groschen Seife kaufen möchte, um sich damit zwei Stunden lang die Hände zu waschen, bevor man es wagt, den Griff zu berühren. Aus 
solchen bis zur Unwirklichkeit überbetonten Einzelheiten baut Gogol' seine Welt vor uns auf, und es kann nicht verwundern, daß man in diesem Zusammenhang von Surrealismus gesprochen hat. Auch der Surrealismus beruht ja auf dem Prinzip der Synekdoche, einer bestimmten bildlichen Objektivation, die zugleich sich selbst und einen ganzen Komplex von unausgesprochenen Beziehungen meint. Surrealistisch sind auch die logischen Abbrüche mitten im Gedanken und die Steigerung der Wirklichkeit zur Groteske, zwei Verfahren, die in Gogol's Stil immer wiederkehren. Schon V. Rozanov hatte 1906, als man sich wieder mehr mit Gogol' zu befassen begann, feststellen müssen: "Gogol' ist der Darsteller der Gegenstände und Erscheinungen nicht in ihrer Wirklichkeit, sondern in ihrem Extrem".

Bei der Schilderung des Verkehrs auf dem Nevskij Prospekt verwendet Gogol' in auffälliger Weise das Stilmittel der Synekdoche: nicht Menschen aus Fleisch und Blut promerieren bier, sondern Backenbärte, Schnurrbärte, tausenderlei Sorten von Hüten, Kleidern und Tüchern, ferner Taillen, sogar so ungewöhnlich schmale, sagt Gogol', wie man sie sich nicht einmal träumen läßt, so schmal wie ein Flaschenhals, und Damenärmel, so luftig wie ein Paar Luftballons, und die Trägerin solcher Ärmel steigt nur deswegen nicht in die Höhe, weil ihr Begleiter sie fest am Arm hält. Zwischen zwei und drei Uhr am Nachmittag, so versichert Gogol', ist der Nevskij Prospekt eine Ausstellung aller hervorragenden Erzeugnisse des Menschen. Und er nennt: einen eleganten Uberrock mit Biberpelzbesatz, eine vollendet griechische Nase, einen gepflegten Backenbart, ein Paar hübsche Augen nebst einem bewunderswerten Hut, einen Ring mit einem Talisman an einem zierlichen Finger, einen Fuß in einem 
bezaubernden Schuh, eine Halsbinde, die Bewunderung hervorrufen muß, einen Schnurrbart, der in Erstaunen versetzt. Der Mensch wird scheinbar nicht nur auf die Ebene von Waren heruntergedrückt, er wird in einzelne Teile zerlegt, nur das Einzelne interessiert hier, das Ganze ist nur wie ein Spuk. Gogol' errät als einer der ersten auch den Fetischcharakter, den die Gegenstände der Mode und bisweilen einzelne Bestandteile der Kleidling annehmen können. Mit ironischer Verwunderung stellt Gogol' fest:

\footnotetext{
"Создатель! какие странные характеры встречаются на Невском проспекте! Есть множество таких людей, которые, встретившись с вами, непременно посмотрят на сапоги ваши, и, если вы пройдете, они оборотятся назад, чтобы посмотреть на ваши фалды. Я до сих пор не могу понять, отчего это бывает. Сначала я думал, что они сапожники, но, однако же, ничуть не бывало: они большею частию служат в разных департаментах... или же люди, занимающися прогулками, чтением газет по кондитерским, - словом, большею частию все порядочные люди."
}

[Schöpfer! Was für seltsame Charaktere man auf dem Nevskij Prospekt trifft! Es gibt eine ganze Menge Leute, die, wenn sie uns begegnen, unbedingt auf unsere Stiefel starren, oder, wenr. wịr vomübergeher, sich umdrehen, um unsere Frackschöße zu betrachten! Ich kann bis jetzt nicht begreifen, woher das kommt. Zuerst dachte ich, daß das alles Schuhmacher seien, aber ganz im Gegenteil. Meistens dienon sie in verschiedenen Departements ... oder es sind Leute, die sich mit Spazierengehen und mit Zeitunglesen in Konditoreien abgeber, - mit einem Wort, zum größten Teil alles ordentiliche Leute.]

Gogol's Psychologie hat manchmal etwas sehr doppelbödiEes, besonders, wenn wie hier, noch die Logik so stark strapaziert wird: aus dem Gesagten scheint ja hervorzugehen, daß Schuhmacher keine ordentlichen Leute sind. Auch Gogol's Humor ist surrealistisch. 
Sein Sinn für das Ornamentale hat Gogol' oft Ladenschilder und Schaufensterdekorationen erwähnen lassen. So ein Ladenschild ist ja die Synekdoche "par excellence", auf ihm erscheint eine Brezel, ein Schaftstiefel oder wie in dem schon zitierten Beispiel eine Schere. Wir wissen, daß die Surrealisten des 20. Jahrhunderts solche Schilder gesammelt haben, und Gogol' führt als Zeichen des Insichgekehrtseins vielbeschäftigter älterer Kollegiensekretäre, Titular- und Hofräte an, daß sie statt der Ladenschilder immer nur eine Mappe mit Dokumenten oder das runde Gesicht des Kanzleidirektors vor sich sehen.

Auf einen Umstand muB man bei Gogol' nachdrücklich hinweisen: die Großstadt ist für ihn nicht nur ein soziales Problem, sondern ebenso auch ein existentielles. Durch die Fixierung des Horizontes auf den engsten Umkreis der Kanzleistube oder des Wohnwinkels tritt bei den von Gogol' entdeckten Großstadtwesen eine Verengerung des Bewußtseins ein, an dessen Peripherie die Welt als Ganzes nur noch als Halluzination in Erscheinung tritt. Gogol' ist in dieser Hinsicht sehr konsequent: er kommt immer wieder auf den sozialen Typus zurück, der in dem Maße, wie er einer fixen Idee verfällt, aus der Mitte der Welt herausgeschleudert wird und sich im Nebel der optischen Illusion verliert. Die Stadt narrt und vernichtet schließlich den, der nicht seine Augen offen hält. Der Maler Piskarev, der einem Wahnbild nachjagt und schließlich in den Selbstmord getrieben wird, ist nicht ein Opfer sozialer Mißstände, sondern er ist existentiell ein schwerpunktloses Geschöpf. Nicht ohne Absicht gibt Gogol' eine detaillierte Beschreibung seiner Lebensumstände. Gogol' rechnet Piskarev zu jenen Künstlern, die nie aus Petersburg herauskommen, die 
vielleicht in der frischen Luft Italiens ihr Talent entfalten wïrden, die sich aber damit bescheiden müssen, die Perspektive ihres eigenen Stübchens aufs Papier zu werfen. So ein Künstler, sagt Gogol', blickt einem nie gerade in die Augen, und wenn er dies einmal tun sollte, dann mit einem ganz trüben und unbestimmten Ausdruck. Ihm fehlt der Habichtsblick des Beobachters oder der Falkenblick des Kavallerieoffiziers. Er antwortet

"часто несвязно, иногда невпопад, и мешающиеся в
его голове предметы еще более увеличивают его
робость."

[oft unzusammenhängend, manchmal unpassend, und die in seinem Kopf durcheinanderfahrenden Gegenstände vergrößern noch seine Schüchternheit.]

Gerade die tollsten und glücklichsten Träume Piskarevs werden aber durch jenes tbel gestört, das allem $z u$ Grunde liegt. Ausgerechnet in den Traum drängt sich die Großstadt als Alpdruck ein, und es ist sehr aufschluBreich, daß hier die Menge als das Drohende erscheint. Piskarev sieht das angebetete Wesen, das in Wahrheit ja ein Straßenmädchen ist, deutlich im Traum vor sich, aber der Weg ist durch eine dieses Wesen umringende Menge verstellt.

\footnotetext{
"Пискарев употребил все усилия, чтобы раздвинуть толпу и рассмотреть ее; но, к величайшей досаде, какая-то огромная голова с темными курчавыми волосами заслоняла ее беспрестанно; притом толпа его притиснула так, что он не смел податься вперед, не смел попятиться назад, опасаясь толкнуть каким-нибудь образом какого-нибудь тайного советника. Но вот он продрался-таки вперед и взглянул на свое платье, желая прилично оправиться. Творец небесный, что это! На нем был сюртук и весь запачканный красками..."
}

[Piskarev wendete alle Anstrengungen auf, um die Menge beiseite zu drücken und sie zu sehen. Aber zu 
seinem größten Arger schob sich immer wieder ein riesenhafter Kopf mit dunklem krausen Haar davor. und auBerdem bedrängte ihn die Menge so, daB er weder vorwärts $z u$ gehen noch rückwarts zu treten wagte, in der Furcht, etwa irgendeinen Geheimen Rat anzustoßen. Aber endlich gelang es ihm doch sich freizuarbeiten, und er besah seine Kleider in dem. Wunsch, sie in Ordnung zu bringen. Himmlischer Schöpfer, was war das! Er trug einen Gehrock, der ganz mit Farbe bekleckst war.J

Der merkwürdige überdimensionale Kopf, der sich hier vor das Wunschbild drängt, findet eine offenbare Parallele in "Sinel"" [Mantel], wo dem armen Kanzleischreiber Akakij Akakievič Bašmačkin auf offener Straße sein entbehrungsvoll erhungerter einziger Schatz, nämlich sein neuer Mantel, buchstäblich vom Leibe gerissen wird. Gogol' läßt den Leser erraten, daß die Diebe nicht irgendwelche realen Ubeltäter sind, sondern Werkzeuge einer anonymen Verschwörung, Machtsymbole der Stadt:

\footnotetext{
"'А ведь шинель-то моя! сказал один из них громовым голосом, схвативши его за воротник. Акакий Акакиевич хотел было уже закричать 'караул', как другой приставил ему к самому рту кулак величиною в чиновничью голову, примолвив: 'А вот только крикни!' "
}

['Der Mantel gehört doch mir!' rief einer von ihnen mit Donnerstimme und packte ihn am Kragen. Akakij Akakievič wollte schon 'Hilfe' schreien, als ein anderer inm seine Faust auf den Mund drückte, die so groB war wie der Kopf eines Beamten, wobei er hinzusetzte: 'Wenn du nur einen Laut gibst!']

Schon das Erscheinen der Diebe in der Dunkelheit ist merkwürdig. Auf einem völlig öden und menschenleeren Platz wachsen sie plötzlich aus dem Boden: "kakie-to ljudi s usami" [irgendwelche Leute mit Schnurrbärten] heißt es im Text, und Akakij Akakievič konnte nicht einmal sagen, was das für Leute waren. Die Szenerie erinnert an einen Angsttraum; denn auf dem Heimweg von der kleinen Gesellschaft, die die Kollegen zu Ehren des neuen Mantels gegeben haben, muß Akakij Akakievič 
immer dunklere und immer ödere Straßen entlanggehen, bis er an jene schicksalhafte Stelle kommt, wo durch eine quer zum Weg verlaufende Straße ein "unendlicher" Platz gebildet wird, der ihn wie eine "strašnaja pustynja" [fürchterliche Wüste] anblickt. Auf diesem "wüsten" Platz, der zum Kreuzweg der ganzen Erzählung wird, ereilt Akakij Akakievič sein Schicksal, und er muB den geheimnisvollen Wegelagerern das kostbarste Objekt abtreten, auf das sich seine wïnsche je gerichtet haben. Zweifellos liegt etwas Symbolbaftes in diesem Raub des Mantels, der Schutzhülle, in die sein Besitzer geglaubt hatte, sich flüchten zu können. Mit diesem Mantel ist auch das Gehäuse verschwunden, in dem sich die Gedanken des armseligen Beamten eingenistet hatten.

Akakij Akakievič sucht an den darauffolgenden Tagen vergebens nach Hilfe. Die ungnädige Exzellenz, die seine Bitten kaum angehört hat, kanzelt ihn im Gefühl eigener überragender Bedeutung $a b$ wie einen Schuljungen und jagt inn hinaus in den Sturm, der "po peterburgskomu obyčaju" [nach Petersburger Art] aus allen vier Windrichtungen bläst. Der scharfe Wind packt den schutzlosen Beamten, und mit den Keimen einer Angina infiziert kehrt Akakij Akakievič nach Hause zurück.

\footnotetext{
"На другой же день обнаружилась у него сильная горячка. Благодаря великодушному вспомоществованию петербургского климата болезнь пошла быстрее, чем можно было охидать..."

[Am anderen Tage zeigte sich bei ihm heftiges Fieber. Dank der großmütigen Hilfestellung des Petersburger Klimas verlief die Krankheit schneller, als man erwarten konnte.]
}

Akakij Akakievič ist vom Tode gezeichnet. Gogol's Anspielung auf das "Petersburger Klima" ist hier viel mehr als eine bloße ironische Randbemerkung zur Gewinnung des Einverständ- 
nisses des Lesers; denn das erkältende Petersburger Klima hat durch die Petersburger Erzählungen von Puškin bis zu Dostoevskij den Wert eines literarischen Motivs erster Ordnung angenommen. Selbst die Symbolisten, insbesondere Andrej Belyj, haben sich der "giftigen Fluida" Petersburgs immer wieder zur inneren Motivierung der Erzählung bedient. In seinem Buch über Gogol' bezieht sich Andrej Belyj ausdrücklich auf die von mir eben zitierte Stelle zur Erklärung einiger Anspielungen in seinem eigenen Großstadtroman "Petersburg". Belyj kannte, das zeigt sich immer wieder, Gogol's Werk fast auswendig.

Es spricht vieles dafür, daß Gogol' den Mantel als das Objekt einer höchst zweideutigen Leidenschaft angesehen wissen wollte, einer Leidenschaft, die sich sehr betont der Leidenschaft nähert, an der Piskarev, der opiumsüchtige Maler, zugrunde geht. Auch Piskarev macht ja einen manischen Prozeß durch:

"Все откинувши, все позябывши, сидел он с сокрушенным, с безнадежным видом, полный только одного сновидения. Ни к чему не думал он притронуться; глаза его без всякого участия, без всякой жизни глядели в окно, обрашенное в двор, где грязный водовоз лил воду, мерзнувшую на воздухе, и козлиный голос разнощика дребезжал: 'Старого платья продать'."

[Alles hatte er von sich geworfen, alles hatte er vergessen, er $s a B$ da mit einem zerknirschten, hoffnungslosen Ausdruck, erfüllt nur.von dem Traumgesicht. Nichts mochte er mehr anrühren; seine Augen blickten ohne jede Teilnahme, ohne jede Lebendigkeit durch das Fenster, das zum Hof hinausging, wo der schmutzige Wasserfuhrer sein Wasser ausgoB, das an der Luft zu Eis wurde, und wo die blökende Stimme des Hausierers erscholl: 'Alte Kleider zu verkaufen.'] 
So wie hier schiebt sich immer wieder das Bild der GroBstadt in die blinden Stellen der Handlung ein, ein paar charakteristische Details, die aber ganz den atmosphärischen Hintergrund bilden.

Als Akakij Akakievič auf dem Weg zu der Abendgesellschaft seiner Kollegen ist - der Rückweg wird ihm den Mantel kosten -, da bemerkt er zum ersten Mal auch etwas von der Stadt - seit Jahren geht er zum ersten Mal wieder bei Nacht aus. Und auch hier verzeichnet Gogol' ein höchst surrealistisch anmutendes Detail:

\footnotetext{
"Акакий Акакиевич ... остановился с любопытством перед освещенным окошком магазина посмотреть на картину, где изобрахена была какая-то красивая женшина, которая скидала с себя башмак, обнахивши, таким образом, всю ногу, очень недурную; а за спиной ее, из дверей другой комнаты, выставил голову какой-то мужчина с бакенбардами и красивой эспаньолкой под губой."
}

[Akakij Akakievič ... blieb neugierig vor einer erleuchteten Geschäftsauslage stehen, um ein Bild zu betrachten, auf dem eine schöne Frau dargestellt war, die gerade einen Schuh auszog und die so ihren Ganzen Fuß, einen auffallend schönen FuB, entblöBte. Hinter ihrem Rücken, in der Tür eines zweiten $\mathrm{Zim-}$ mers zeigte sich der Kopf eines Mannes mit Koteletten und mit einem hübschen Spitzbart unter der Lippe.]

Die Stelle scheint ohne Beziehung zur Handlung, denn Akakij Akakievič ist ja nicht der Mann, an den sich solche Plakate wenden, aber gerade in diesen surrealistischen Brüchen und letzten Fndes doch unmittelbar einleuchtenden Assoziationen zeigt sich Gogol's sicherer Instinkt für künstlerische Wirkungen. Gerade auf dieses Detail kommt es ihm an, und Andrej Belyj hat vollkommen recht, wenn er von Gogol's Sujet sagt: 
"Мелочи его выглубляют; в каждой 'зарыта собака'; без вырытия зтих погребенных 'собак' сюжет не сюжет."

[Die Einzelheiten vertiefen es; in einer jeden ist bei ihm der "Hund begraben", und ohne die Exhumierung dieser Hunde" ist sein Sujet kein Sujet.J

"Сюжетная мелодия", fährt Belyj an einer anderen Stelle seines Gogol'-Buches fort:

\footnotetext{
"Фабула, - интерференция насквозь осюжетенных мелочей, которые - не аккомпанемент, а само голосоведение; выньте-ка из них 'чистый' сюхет, - он станет заемным у Пушкина каламбуриком; и сотрите-ка с 'Носа' пудру двумыслиц, 'Нос' - шутка с задворков журналов эпохи Гоголя."
}

[Die Sujetmelodie, die Fabel, das ist die Interferenz der durch und durch sujetisierten Details, die nicht die Begleitung bilden sondern die Stimmfühmung selbst ... Wenn man aus ihnen das "reine" Sujet herausholt, dann wird es zu einem bei Puškin entlehnten Calembour, und wenn man den Puder der Zweideutigkeiten von Gogol's 'Nase'wischt, dann ist die 'Nase ein Hintertreppenwitz aus den Zeitschriften der Epoche Gogol's.]

Leider kann ich aus Rücksichtnahme auf die Zeiteinteilung nicht mehr auf Gogol's Anekdote von der "Nase" eingehen, aber sicher ist so viel, daB auch der Held dieser Geschichte, der Kollegienassessor Kovalev, ein Mensch ohne existentiellen Schwerpunkt ist, und daß die ihm auf rätselhafte Weise abhanden gekommene Nase dieser Situation augenfälligen Ausdruck verleiht. Insofern dringt Gogol's Blick viel tiefer als der Blick der bloßen Sittenschilderer der Großstadt. Gogol' entwirft, wie ich schon einleitend.behauptet habe, eine wirkliche Physiognomie der GroBstadt und ihrer Bewohner.

Der existentielle Defekt, den Gogol' überall so sichtbar hervortreten läßt, beruht allerdings, das soll zum Abschlue nicht unterschlagen werden, wesentlich auf der Deu- 
tung, die Schelling und die deutschen Romantiker diesem Phänomen haben angedeihen lassen. Er beruht auf der Spannung zwischen Sympathie und Teilnahmslosigkeit, zwischen Harmonie und Disharmonie der Kräfte innerhalb der menschlichen Natur selbst, so wie sie die Romantiker als widersprüchlich angelegt verstanden. In der Teilnahmslosigkeit, in der Vereinzelung, überall, wo die Bande der allumfassenden Sympathie zerrissen sind, zeigt sich, wie Schelling es nennt, eine Universalkrankheit, eine Ataxie der Kräfte, durch die die normale Temperatur in eine Distemperatur verkehrt wird, und als deren Folge alles Wesenhafte - ich folge wieder Schelling in "meteorische Erscheinung" aufgelöst wird. Gerade aus diesem Grunde, d.h. als Symptom der Universalkrankheit, fürchtet Gogol' die Großstadt, und er läßt seine Erzählung vom Nevskij Prospekt mit einer Warnang ausklingen:

"О, не верьте этому Невскому проспекту! Я всегда закутываюсь покрепче плащом своим, когда иду по нем, и стараюсь вовсе не глядеть на встречаюиеся предметы. Все обман, все мечта, все не то, чем кажется!"

$[0$, glaubt nicht diesem Nevskij Prospekt! Icb hülle mich immer fester in meinen Mantel ein, wenn ich ihn entlanggehe, und ich bemühe mich, überhaupt nicht die auf mich zueilenden Gegenstände zu betrachten. Alles Trug, alles Phantasterei, alles nicht das, was es zu sein scheint!]

L i t e r a t u r a n $g$ a b e n

A n n e n ko v, P. V.: Vospomiranija o Gogole. Lenirgrad 1928. (Academia.)

$B$ a $u$ d e $l a i r$ e, Charles: Ies paradis artificiels. Paris 1928.

B e 1 y j, A.: Masterstvo Gogolja. Issledovanie. Moskva 1934. 
B e $n j$ a m $i n$, W.: Paris, die Hauptstadt des XIX. Jahrhunderts. In: W. Benjamin: Schriften, herausgegeben von Th. W. Adorno und Gretel Adorno. Bd. I, Frankfurt/M. 1955.

G $\circ$ e $t h e, j . W_{\text {. }}$ von: Le Livre des Cent-et-Un (Tome I. Paris 1931). In: Goethes sämtliche Werke. Bd. XIII, Leipzig: Insel o. J.

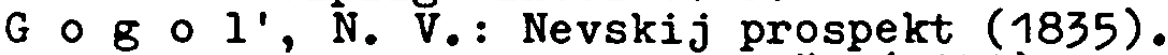

$G \circ 8 \circ l^{\prime}, N_{0}$ V.: Mertvye duši (1842).

G $\circ$ g $\circ$ I', N. V.: Sinel' (1842).

G $r$ i g o r'e v, Apollon: Dostoevskij i skola sentimental'nogo naturalizma (otryvok). In: N. V. Gogol'. Materialy i issledovanija. Neizdannye $i$ zabytye stat'i o Gogole. Moskva 1936.

G r i g O r'e v, Apolion: Stichotvorenija i poemy. MoskvaLeningrad 1966. (Biklioteka poéta. Malaja serija.)

$\mathrm{N}$ i l s s o n, Nils Ake: Gogol et Péterbourg. Recherches sur les antécédents des Contes Péterbourgeois. Stockkolm 1954 .

P u š k i n, A. S.: Mednyj vsadnik (1834).

$R \circ z$ a $r \circ v$, Vasilij: Legenda o velikom inkvizitore. Dve stat'i o Gogole. Sanktpeterburg 1906.

$\mathrm{S}$ c h e l l i $\mathrm{n}$, F. W.: Philosophische Untersuchungen uber das Wesen der menschlichen Freiheit und die damit zusammenhängenden Gegenstände (1809).

$\mathrm{V}$ i $n \circ \varepsilon \mathrm{r}$ a d o v, V. V.: Gogol' i natural'naja škola. Leningrad 1925. 


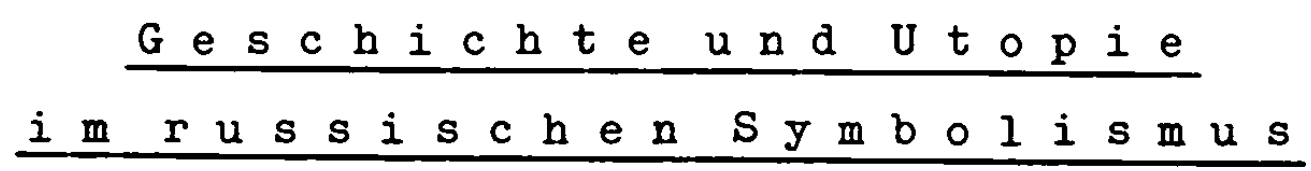

Die Dichter des russischen Symbolismus sind in der Nachwelt sehr unterschiedlich beurteilt worden, je nach dem Grad der Fähigkeit und der Bereitschaft des Lesers, auf eindeutige ideologische Positionen zu verzichten und an der Vermischung des Sakralen und des Profanen keinen AnstoB zu nehmen.

Es gibt bei den Symbolisten viele symbolistische Theorien und kein einheitliches philosophisches System, aber es gibt viele symbolistische "Objekte" (um mit Zdeněk Mathauser zu sprechen), von denen ein profaner wie auch ein sakraler Gebrauch gemacht werden kann.

In meinem heutigen Vortrag, d.h. in einer leider nur fragmentarischen Betrachtung des russischen Symbolismus, möchte ich diesen Sachverhalt mit dem Blick auf eine ganz bestimmte Thematik betrachten, mit dem Blick auf Geschichte und Utopie.

Grundsätzlich zeigten sich die Symbolisten an der Betrachtung von kausalen historischen Verknüpfungen uninteressiert, aber ohne Frage spielte bei ihnen die Geschichte als Analogon zur Gegenwart eine nicht unbedeutende Rolle, und ebenso fraglos verlängerten sie ihre eigenen geschichtlichen Erfahrungen oder Enttäuschungen auch in die Zukunft. Die Geschichte ist

(Vortrag erstmalig gehalten am 16.9.1969 im Ustav jazyki a literatur der CSAV vor der Literárnèvědná společnost pri

CSAV in Prag.) 
indessen für den modernen Dichter alles andere als ein ehrfürchtig betretener Raum, und es ist vielleicht bezeichnend, daB A. Blok dem alten Rom im Wachsfigurenkabinett begegnete:

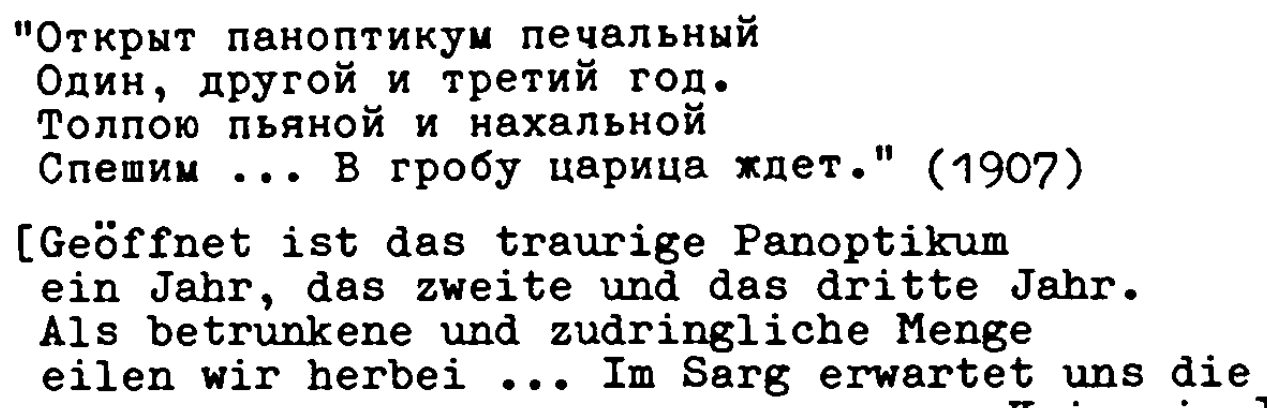

Kaiserin.]

Es handelt sich um Kleopatra, deren Zauber hier wirksam werden soll, und die der Dichter dabei aufmerksam betrachtet:
"Я сам, позорный и продажный, С кругами синими у глаз, Пришел взглянуть на профиль важный, На воск, открытый напоказ ..."

[Ich selbst, bedeckt mit Schmach und käuflich, mit blauen Ringen unter den Augen, bin gekommen, um das bedeutende Profil zu sehen, das Wachs, das zur Schau gestellt ist.]

Der Symbolismus ist auch in RuBland mit einem ausgesprochen endzeitlich orientierten Geschichtsbewußtsein in die Arena getreten, mit dem Bewußtsein der großen kulturellen und zivilisatorischen Ermüdung, die einst den Niedergang des römischen Imperiums begleitete.

"Мы-поздние певцы: ...",

so dichtete Konstantin Fofanov 1891, "мир, злой и обветшалый, Оставил только то для нас,

О чеи не грезил он, что проклинал, усталый, Стремяся рухнуть. кахдый час..."

[Wir sind spate Sänger: die böse und altersschwache hat für uns nur das übriggelassen, wovon sie sich nichts hat träumen lassen, was sie verflucht hat, die müde, in ihrer Tendenz, jeden Augenblick in sich zusammenzufallen.] 
Das klingt dekadent und ruft uns eine andere Zeile ins Gedächtnis: "Ah! tout est bu, tout est mangé! Plus rien à dire!" - Das ist Verlaines Klage aus dem berïhmten Sonett "Langueur" (1883), das mit den Zeilen beginnt:

"Je suis l'Empire à la fin de la décadence Qui regarde passer les grands Barbares blancs ..."

Mit den Barbaren haben die Symbolisten wirklich gerechnet und darum erscheinen uns ihre Vorahnungen, geheimen Wünsche oder Angstträume folgerichtig, auch wenn die Wirklichkeit des 20. Jahrhunderts manche von diesen Träumen schon überboten hat.

Allerdings gibt es in der symbolistischen Literatur auch eine Art von selbstmörderischer, ästhetischer Konspiration mit den neuen Barbaren, die allem Anschein nach durch Friedrich Nietzsche vermittelt ist; wir kommen auf das Problem noch zurück. Ubertreibungen dieser Art sind ein Protest gegen jene bürgerlich-imperialistische Lebensordnung, deren prahlerisches Selbstbewußtsein auch in RuBland vordergründig triumphierte.

Die Stellung des Dichters in der Gesellschaft wird von den Symbolisten meistens nur indirekt dargestellt, durch die bewuBte Negation aktueller gesellschaftlicher Wirklichkeit, aber z.B. bei A. Blok gibt es doch auch manche Auseinandersetzungen mit der eigenen gesellschaftlichen Lage. In dem lyrischen Drama "Korol' na ploščadi" [Der König auf dem Platz], 1906, und in dem eng damit verbundenen dramatischen Dialog "Dialog o ljubvi, poèzii i gosudarstvennoj službe" [Dialog über die Liebe, die Dichtung und den Staatsdienst] wird der Dichter herausgefordert, eine klare Position zu beziehen. Gegenspieler sind der Narr, der für sich den "gesunden Menschen- 
verstand" (zdravyj smysl) in Anspruch nimmt, der Baumeister (zodčij) und der Diener des Hofes. Der Dichter wählt in beiden Stücken nicht das Engagement für die Gesellschaft, sondern die unbedingte Freiheit, die Freiheit des Betrachters. Die wichtigste Selbstkritik des Dichters ist das Eingeständnis der Unfähigkeit zur Aktivität:

"Голодный добывает хлеб трудом. Оскорбленный
мстит. Любовник говорит женщине: будь моею.
Но я сыт, и никто не оскорбляет меня ...
Мне нечего достигать - я обречен на тоску."

[Der Hungrige erwirbt sein Brot durch Arbeit. Der Beleidigte rächt sich. Der Liebhaber sagt zur Frau: sei mein. Aber ich bin satt, und niemand beleidigt mich .... Ich brauche nichts zu erreichen ich bin dem Seelenschmerz geweiht.]

Der Zustand der unerfüllten Sehnsucht, der schwermütigen russischen "toska", macht oft die Grundtonalität der symbolistischen Dichtung aus (vgl. Verlaines "Langueur"), und im Verein mit dem Uberdruß an den gegebenen Zuständen treibt die dichterische Phantasie um so mehr wilde und dämonische Blüten.

Der Wunsch nach Zerstörung des irdischen Gefängnisses zeitigt die problematische Bereitschaft, mit den künftigen Barbaren zu kokettieren und die Orgien eines "Weltunterganges" für Zeichen der kommenden Freiheit zu halten. Soweit dieses Denken in utopische Bilder mündet, werden technische Zivilisation und imperialistische Herrschaft im Stil der romantischen Gegenutopie zu den Dämonen des Menschen gemacht und durch Untergänge beseitigt.

Diese Tendenz ist bei Brjusov schon um die Jahrhundertwende aktuell (1900-01), z.B. in der Dichtung "Zamknutye" [Die Eingeschlossenen]. Diese "Otryvki iz nezakončennoj poèmy" [Bruchstücke aus einem unvollendeten Poem] sind ein größeres 
Gedicht mit historischer und utopischer Thematik, gedacht zunächst einmal als Echo auf die Begegnung mit der altertümlichen Stadt Reval:

"Весь Город был овеян тайной лет.

Он был угрюм и дряхл, но горд и строен, и...................................

Иных столетий пламенную дрохь."

[Die ganze Stadt war vom Geheimnis der Jahre umweht. Sie war düster und baufällig, aber stolz und ebenmäBig,

Und alles verbarg in sich das frühere Leben,

Das flammende Zucken anderer Jahrhunderte.]

Die museale Stadt jagt dem Betrachter einen Schauer ein, der sich bei der Wanderung durch gotische Kirchen, Sitzungszimmer der Gelehrten, Künstlerwerkstätten und Plätze immer mehr zu der Gewißheit verdichtet, daß die Seele der Stadt in die Hände der "vnešnost"" [Außerlichkeit] und der "pošlost'" [Banalität] geraten ist, daß sie von einer Gesellschaft bewohnt wird, die reif zum Untergang ist.

Im letzten Teil der Dichtung geht Brjusov aber noch weiter und verlängert die Vision in eine utopische Zukunft. Die alte stadt deutet voraus auf die Stadt der Zukunft, weil sie dieselbe "pošlost"" verkörpert.

"И как кошмарный сон, виденьем беспошадным, Чудовищем размеренно-громагтіsi, С стеклянным черепом, покрывшим шар земной, Грядущий Город-дом являлся предо мной."

[Und wie ein Alptraum, wie eine gnacenlose Vision, erschien als ein gemessen-riesenhaftes Ungeheuer, mit gläsernem Schâdel, der die ganze Erdkugel bedeckte, die Stadt der Zukunft als Behausung vor mir.]

Diese gläserne Stadt der pošlost' ist sogar noch schlimmer als die alte, und daher muß einmal das Ende unserer Epoche kommen, nach welchem an der verödeten Seine wieder die wölfe heulen 
werden, die Wände des Tower aber spurlos verschwunden sein werden. Die völker werden wie Tiere übereinander herfallen und sogar an Bücherverbrennungen hat Brjusov gedacht:

"В руинах, звавшихся парламентской палатой, Как будет радостен детей свободных крик, Как будет весело дробить останки статуй И складывать костры из бесконечных книг."

[In den Ruinen, die man Parlamentsgebäude nannte f wie froh wird da das Geschrei freier Kinder erschallen,/wie lustig wird es sein, die Reste der Statuen zu zerklopfen/und Scheiterhaufen aus endlosen Büchern aufzuschichten.]

Die "Freiheit", die aus solchem Ruin resultieren würde, haben die Symbolisten als Befreiung von ihrer "toska" begrüßt. Brjusov beendet sein Gedicht folgendermaßen:

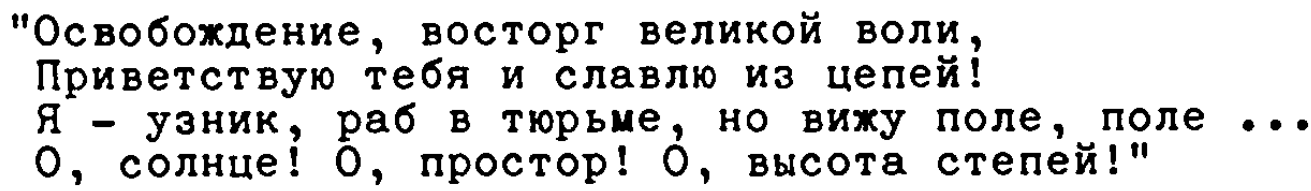

[Befreiung, Begeisterung der groBen Willkür, ich begruße dich und ruhme dich in meinen Ketten! Ich bin ein Gefangener, Sklave im Gefängnis, aber ich sehe freies Feld, Feld ... o Sonne! O Weite! O Höhe der Steppen!]

Nach 70 Jahren wundert man sich in mancher Hinsicht über die naiv-unbekümmerten Zukunftsträume einer Generation, die den Weltkrieg, die Revolution und den Bürgerkrieg erleben sollte, und man muß wohl den "Ton" des ganzen Hymnus auf die Zerstörung mit Brjusovs Hang zur rhetorisch-pathetischen Attitüde zu erklären suchen. Aber selbst ein seriöser Dichter wie Vjačeslav Ivarov huldigte gelegentlich solchen anarchistischen Gelüsten wie z.B. in dem Gedicht "Kočevniki krasoty", [Nomaden der Schönheit], das sich in dem Band "Prozračnost"" [Durchsichtigkeit] (1904) findet: Die Künstler, die "Nomaden der Schönheit", werden darin aufgerufen, die Fluren der Sklaven zu verwïsten und Neuland aus den Steppen zu gewinnen: 


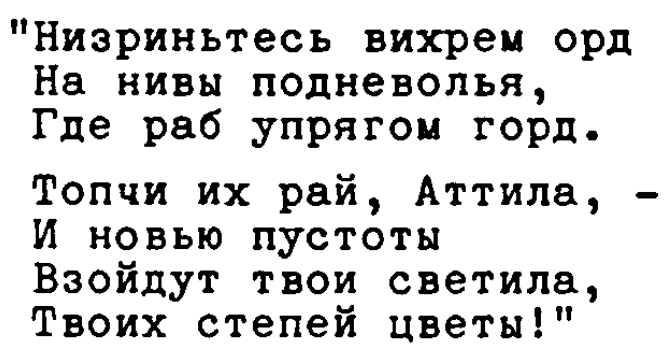

[Stürzt euch wie wirbelnde Horden auf die Fluren der Unfreiheit, Wo der Sklave auf sein Gespann stolz ist.

Zertrampele ihr Paradies, Attila, und als Neuland der Wüste werden deine Sterne aufgehen, deiner Steppen Blumen!]

Während der ersten Revolution nimmt Brjusov in dem bekannten Gedicht "Grjaduščie gunny" [Die nahenden Hunnen] vom August 1905 den gleichen Gedanken wieder auf und feiert den dionysischen Tanz der Barbaren.

Eine ähnliche Zukunftsvision hat Brjusov ja auch in dem Drama "Zemlja" (1905) gestaltet, wo in der Ausgangssituation die ganze Erde in ein System von Maschinen und technischen Vorrichtungen verwandelt ist. Die Wohnungen, alle mit Glas gedeckt, sind von der Natur und vom Kosmos abgeschirmt und in künstliche Umwelten verwandelt. Ein Fehler im System bringt schließlich den Mechanismus in eine kritische Lage, und die letzten Menschen sehen keinen Ausweg mehr. Nur zwei Menschen, denen noch ein Rest von Einsicht geblieben ist, steigen hinab in den zentralen Schaltraum und reißen durch einen Hebeldruck die Dächer dieser letzten Stadt auf. Das lange zurückgehaltene Sonnenlicht fällt gleißend in die Säle der künstlich klimatisierten Stadt, und die Menschheit, die sich in das Innere der Erde verirrt hat, geht schmählich in diesem Himmelslicht zugrunde.

Diese Utopie, die ebenfalls eine romantische Gegenutopie ist, muß man zweifellos im Zusammenhang mit den technologi- 
schen Zukunftsvisionen sehen, die in England und Frankreich schon Ende des 19. Jahrhunderts modern wurden und die dann im Werk des auch in Rußland viel gelesenen H.G. Wells kulminierten.

Das Geschichtsbewußtsein der Symbolisten ist weiterhin aber auch von bestimmten okkulten und magischen Vorstellungen geprägt, besonders von der gnostischen Idee eines unversöhnten, eines unbefriedeten Kosmos. Menschliche Verhältnisse und kosmische Verhältnisse entwickeln sich analog, und Andrej Belyj hat 1905 unter dem Eindruck des russisch-japanischen Krieges in der Zeitschrift "Vesy" [Die Waage] verschiedene programmatische Erörterungen veröffentlicht, die auf diese merkwürdige Kommunikation mit dem kosmischen Geschehen abzielen. In "Apokalipsis v russkoj poèzii" [Die Apokalypse in der russischen Poesie] (1905) betont Belyj die Identität des Chaos im einzelnen individuellen. Bewußtsein, d.h. in den Herzen der Menschen, mit dem Chaos in der Tiefe des Kosmos. Die Wirklichkeit, die "dejstvitel'nost'" hat dabei sogar nur eine Zeïgefunktion, ist nicht das Geschehen selbst. Die historische Wirklichkeit verflüchtigt sich in Belyjs Vorstellung zum Schein, zum "prizrak" [Phantom] zur Maske, zur Chimäre:

"Я ждал извне призраков, намекающих о происходящем внутри. Я знал: над человечеством разорвется Фейерверк химер."

[Ich wartete auf Phantome von außen, die auf das deuten würden, was im. Innern vorging. Ich wußte: über die Menschheit würde ein Feuerwerk von Chimären losgehen.]

Historisches Geschehen, auch den Krieg und die Revolution, will Belyj nur in seiner symbolischen Funktion gelten lassen, als Verdunkelung des Lichtes der Wahrheit durch Staub- 
vorhänge oder durch vulkanische Rauchwolken, und die Gehilfen des Bösen sind der rote Drache der Apokalypse, und der rote Hahn (krasnyj petuch) der brennenden Gutshäuser:

"Это туманные облака, а не действительность; и войны вовсе нет: она - порохдение нашего больного воображения, внешний символ в борьбе вселенской души с химерами и гидрами хаоса."

[Das sind nebelhafte Wolken, aber nicht Wirklichkeit; und der Krieg findet gar nicht statt: er ist die Ausgeburt unserer kranken Einbildungskraft, äußeres Symbol im Kampf der Seele des Universums mit den Chimären und Hydren des Chaos.]

"Vselenskaja duša" [Seele des Universums] ist überhaupt ein zentraler ontologischer Begriff bei den Symbolisten ("Vseduša" bei Vjačeslav Ivanov).

Diese symbolistische Geschichtstheorie präzisiert Belyj in den nächsten Monaten in der gleichen Zeitschrift "Vesy" noch weiter. In "Chimery" (1905) spricht er von der "Maske der Kausalität" (maska pričinnosti), die nichts anderes darstelle als das Schlangenhaupt der Medusa. Die Kausalität sei eine bloße Larve, hinter der sich ein leerer und finsterer Brunren auftue: "Kolodez' mraka i pustoty" [Brunnen der Finsternis und der Leere.] In "Chimery" nennt Belyj den Weg zur Freiheit einen Weg aus dem blauen Gefängnis (golubaja tjur'ma) der Welt durch das "Labyrinth des Geistes" zum ewigen Himmel der Freiheit (k večnomu nebu svobody).

Diese Begriffe, die ja eine Art von universaler Erlösungsmystik enthalten, sind übrigens auch ein direktes Echo auf Brjusovs Kunstphilosophie, die in dem Essay "Ključi tajn" [Schlüssel der Geheimnisse] (1904) zu finden ist. Auch Brjusov nimmt das von A. Fet stammende Stichwort "blaues Gefängnis" (golubaja tjur'ma) auf und meint, die Künstler schmiedeten 
mit ihren Werken die "Schlüssel der Mysterien" (ključi tajn), um die Türen dieses Gefängnisses aufzusperren, die Türen "zur ewigen Freiheit". Auf die Gesetze der Kausalität verzichtet auch Brjusov für die Kunst ausdrücklich, denn Kausalität brauche nur unser geordnetes wissenschaftliches Bewußtsein. Dieses Bewußtsein erfasse aber gar nicht die Realität und könne daher auch nicht zur Befreiung führen:

"Все наше сознание обманывает нас, перенося свои свойства, условия своей деятельности, на внешние предметы. Мы живем среди вечной, исконной лжи."

[Unser gesamtes Bewußtsein betrügt uns, indem es seine Eigenschaften, die Bedingungen seiner Tätigkeit auf die äußeren Gegenstände überträgt. Wir leben in einer fortwährenden, längst bestehenden Lüge.]

Diese, teilweise vom Neukantianismus beeinflußte Erkenntnistheorie hat A. Belyj später in seiner Arbeit:"Emblematika smysla" ausgearbeitet und mit interessanten theosophischen und kabbalistischen Erläuterungen angereichert. Wir wollen die Einzelheiten beiseite lassen und uns nur an Brjusovs Diktum (aus "Ključi tajn") erinnern:

"Искусство, может быть, величайшая сила, которой
владеет человечество."

[Die Kunst ist vielleicht die größte Kraft, die die Menschheit besitzt.]

Die Kunst, die die Symbolisten gern als "theurgische" Kunst apostrophieren, ist in diesem Verständnis tatsächlich auf die Befreiung der Menschen gerichtet, und somit ist die Richtung auf die Utopie schon im Denkansatz mitgegeben.

Die historische Menschheit wird im Symbolismus sehr stark als eine Einheit empfunden, und eigentlich sind alle geschichtlichen Probleme noch für eine künftige Lösung aufgehoben. Die 
Symbolisten waren Kosmopoliten. Die Einheit des Weltschicksals fesselte sie stärker als die vaterländische Geschichte. Merežkovskijs Roman "Petr i Aleksej" macht mit seiner russischen Thematik keine Ausnahme, der Roman ist ja nur das letzte Glied in der Trilogie "Christos i Antichrist", und das ist wahrlich ein universales Thema. Peter der GroBe ist im übrigen in der neueren russischen Literatur so etwas wie das Symbol für den Eintritt RuBlands in die Weltgeschichte, und das Denkmal des Zaren von Falconet, der "Mednyj vsadnik" [Der eherne Reiter], geistert fortwährend auch durch die symbolistische Literatur.

Gedichte und Erzählungen aus der russischen Geschichte muß man schon mit einiger Geduld suchen, wenigstens in der Frühzeit des russischen Symbolismus. Durchaus nicht auf der Höhe befindet sich z.B. Brjusov in dem Gedicht "Razorennyj Kiev" [Verwüstetes Kiev] 1898, das mit der langweiligen Strophe endet:

"Всю ночь бродили мы, отчаяньем объяты
Среди развалин тех, рыдая о былом;
Мы Утром все в слезах пошли своим путем ...
Ещё спустя три дня открылись нам Карпаты."

[Die ganze Nacht irrten wir umher, von Verzweiflung erfabt

inmitten jener Ruinen, über das Vergangene schluchzend;

wir gingen alle am..Morgen in Tränen unseres Weges ... Schon drei Tage später enthüllten sich vor uns die Karpaten.]

Das ist eher eine lustlose Pflichtübung als dichterische Inspiration. Das Thema der russischen Geschichte gewinnt nicht vor dem Jahr 1908 Sprache in Bloks berühmten Gedichten aus dem Zyklus "Na pole Kulikovom" [Auf dem Kulikovo-Feld]:

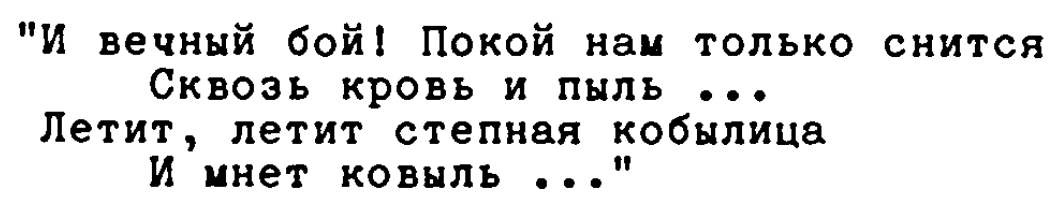


[Und Kampf in Ewigkeit! Die Ruhe träumt uns bloB durch Blut und Staub.

Es fliegt, es fliegt die Steppenstute und druckt das Steppengras nieder ....

Interessant ist, $\mathrm{daB}$ Blok diese Gedichte wie Gegenwart empfindet und $d a B$ er gemeinschaftliches Handeln unterstellt:

"Пјсть ночь. Домчимся. Озарим кострами Степную даль.

В степном дыму блеснет святое знамя и ханской сабли сталь."

[Soll Nacht sein. Wir werden zum Ziele kommen. Mit Lagerfeuern werden wir die Weite der Steppe hell machen.

Im Rauch der Steppe wird das heilige Feldzeichen aufblitzen und der Säbel des Khans aus Stahl.]

Hier ist der Ort, wo sich Geschichte in Utopie verwandeln kann, wo Vergangenheit, Gegenwart und Zukunft miteinander verschmelzen. Die Jahre zwischen dem russisch-japanischen Krieg und dem Weltkrieg sind die Zeit, in der sich RuBland seines eigenen "asiatischen" (skythischen, tatarischen) Erbes und seiner "eurasischen" Lage bewußt wird. Unter diesem Gesichtswinkel betrachtet Andrej Belyj in seinem Roman "Peterburg" (1912-1914) die aus dem 19. Jahrhundert ererbte ost-West-Problematik RuBlands, und hier liegt auch der Bezugspunkt für Bloks Geschichtsphilosophie in dem Gedichtzyklus "Na pole Kulikovom" (bestehend aus insgesamt fünf Gedichten).

Das stark ausgeprägte eschatologische, endzeitliche Bewußtsein der Symbolisten fixiert das eigentlich historische Interesse auf Epochen einer Staats- und Kulturkrise, der Wendung von einem Kulturkreis zum anderen (wie z.B. der Epoche Peters I.).

Die beiden großen historischen Romane, die Valerij Brjusov, selbst ein studierter Historiker, geschrieben hat, 
führen uns in eindeutig "späte" und morbide Gesellschaften, in das spätgotische Köln der Humanisten, Alchimisten und Glaubensfanatiker ("Ognennyj angel") [Der feurige Engel] und in das spätrömische Italien des 4. Jahrhunderts ("Altar' pobedy") [Der Siegesaltar].

Der historische Hintergrund ist hier durchaus kompetent geschildert; Brjusov hat für beide Romane einen ganzen Apparat von gelehrten Anmerkungen beigesteuert, aber sämtliche handelnden Personen sind in ihren Reaktionen Angehörige der dekadenten Gesellschaft des frühen 20. Jahrbunderts, und "Ognennyj angel" ist ja direkt ein Schlüsselroman mit Beziehungen zu Brjusovs persönlichem Bekanntenkreis. Beide Romane sind in der "Ich-Form" erzählt, und dadurch verstärkt sich noch die Illusion der unmittelbaren Teilnahme an der Handlung. Die Identifikation mit der erzählenden Hauptperson wird dem Leser aufgenötigt.

Das eigentliche Thema ist in beiden Romanen die Bedrohung der Gesellschaft von innen, der Augenblick, wo im Zuge der Ablösung zweier Kulturen höchste Reife in innere und äußere Barbarei umschlägt. Dabei mischt sich auch hier das Profane mit dem Sakralen, beide Romane handeln von Mißbräuchen des Glaubens und von religiösen Ferversionen.

Wenn wir uns fragen, was Brjusov - abgesehen vom rein antiquarischen Interesse - bewogen haben mag, dem symbolistischen Roman eine historische Folie zu geben, so dürfen wir die Entscheidung darin sehen, daB Brjusov die entscheidenden inneren Momente der Ablösung einer Kultur durch die folgende im Auge hatte, die Ablösung der Antike durch das Christentum, des Mittelalters durch die Neuzeit. Das Auftreten von mystischen und okkulten Sekten, das Wirken der Magie, Verblendung 
und Hysterie, das Niederreißen moralischer und sexueller Schranken sind das eigentliche Thema dieser Romane. Die Symbolisten waren davon überzeugt, selbst in einer Zeit der permanenten Transformation $\mathrm{zu}$ leben, und die gleiche Thematik beherrscht daher auch das utopische Schrifttum der Symbolisten. Andrej Belyjs Zeitromane "Serebrjanyj golub" [Die silberne Taube] und "Peterburg" gehören typologisch zur gleichen Kategorie, sie spielen in der Interferenzzone zweier miteinander unvereinbarer Kulturen, und wie in Brjusovs historischen Romanen ist die Handlung in höchstem Grade experimentell im Sinne einer tberschreitung von normalen Verbotsgrenzen. Die eingebildete Omnipotenz des symbolistischen Dichters macht daneben aus der Geschichte ein Feld für Spiele und Maskeraden, in denen die zeitliche Distanz ausgelöscht scheint. Die Geschichte steht als Vergnügungsperk oder Lustgarten offen, so wie es sich Brjusov in dem Gedicht "Fonariki" [Lampions] (1904) träumt :

"Столетия - Фонарики! о сколько вас во тьме,
На прочной нити времени, протянутой в уме!"

[Jahrhunderte - Lampions! O wieviele gibt es von euch im Dunkel,

auf der festen Schnur der Zeit, gezogen im Geist!]

Nur Girlanden von bunten Lichtern signalisieren die einzelnen Epochen, die nebeneinander aufgereiht sind: Assyrien, Agypten, Indien, Griechenland, Rom:

"О,Рим, свет ослепительный одиннадцати чаш:

Ты - белый, торжествующий, ты нам родной, ты наш!"

[0 Rom, blendendes Licht der elf Schalen:

Du bist weiß, triumphierend, du gehörst zu uns, du bis unser!]

Die letzten zwei Jahrtausende werden ziemlich schnell gerafft: das Werden Europas ist für Brjusov von keinem erkennbaren $\mathrm{Be}-$ 
lang. Gerade noch Dante verdient nach Rom eine Zeile:

"Век Данте - блеск таинственный, зловеще золотой ..."

[Die Zeit Dantes - ein geheimnisvoller Glanz, bedrohlich golden ....]

Mit Leonardo, mit Luther, mit dem Zeitalter der leichtlebigen Marquisen und mit der Revolution geht es weiter. Ein Bündel von Blitzen ist diese französische Revolution:

"Сноп молний - Революция! За ним громадный шар, 0 , ты, век девятнадцатый, беспламенный похар!"

[Ein Bündel von Blitzen - die Revolution! Nach ihr eine riesige Kugel,

O, du, neunzehntes Jahrhundert, schwelender Brand!]

Die Zukunft bleibt vorläufig ganz dunkel, aber ihr gilt das inbrünstige Flehen des Dichters:

"Но вам молюсь, безвестные! еще в ночной тени Сокрытые, не жившие, грядущие огни!"

[Doch zu euch bete ich, unbekannte! noch vom Schatten der Nacht

verhüllte, noch nicht lebendige, Lichter der Zukunft!]

Die Weltgeschichte ohne Rußland, das ist vielleicht das wirklich Auffallende an diesem Gedicht. Brjusov ahnte aber doch wohl, daß die "grjaduščie ogni" [Lichter der Zukunft] bald aufleuchten würden, nun auf russischem Boden. Dem jungen Brjusov stand aber ganz sicher Assyrien näher, mit dessen König Assargadon er sich früh identifiziert hatte:

"Я исчерпал до дна тебя, земная слава!

И вот стою один, величьем упоен,

Я, вождь земных царей и царь - Ассаргадон." (1897)

[Ich habe dich bis zur Neige ausgekostet, Ruhm der Erde!

Und da stehe ich allein, berauscht von der Größe, ich, der Führer der Kaiser dieser Erde und Kaiser - Assargadon.]

In "Fonariki" ist Assyrien denn auch der erste Abschnitt 
gewidmet:

"Ассирия! Ассирия! мне мимо не пройти! ХочУ полюбоваться я на твой багряный свет: Цветы в крови, трава в крови, и в небе красный след ..."

[Assyrien! Assyrien! daran ist nicht vorbeizukommen! Ich will mich an deinem Purpurlicht ergötzen: Blumen im Blut, Gräser im Blut, und am Himmel die rote spur ....]

Vom Feuer und blutroter Farbe sind die Symbolisten besessen, wie sich schon in $\mathrm{K}$. Bal'monts "Gorjaščie zdanija" [Brennende Bauwerke] (1900) zeigt. Hier spielen sowohl mystische als auch apokalyptische und satanistische Komponenten eine Rolle, und mit der Symbolik dieser roten Farbe würde man wahrscheinlich wesentliche Seiten des russischen Symbolismus erfassen. Wir haben schon von dem "krasnyj drakon" [roten Drachen] gehört, von dem "krasnyj petuch" [roten Hahn], vom "Ognennyj angel". Man könnte aber auch an den "roten Domino" in Andrej Belyjs "Peterburg" erinnern, der auf der "profanen" Ebene diese Symbolik übernimmt.

Die innere Bedrohung der Gesellschaft durch die Barbaren, von der ich vorhin sprach, hat Brjusov $1905 \mathrm{zu}$ einer interessanten Utopie inspiriert, die damals in der Zeitschrift "Vesy" erschien: "Respublika Južnogo Kresta" [Republik des Südkreuzes]. Hinsichtlich der gesellschaftlichen Verhältnisse, die Brjusov in dieser Erzählung beschreibt, handelt es sich ebenso um eine Gegenutopie wie in "Zamknutye" und in dem Drama "Zemlja". Die Hauptstadt der über dem Südpol sich erstreckenden, fernen Republik heißt "Zvezdnyj gorod" [Sternenstadt], aber alle Straßen und Häuser sind nur elektrisch erhellt, weil die stadt durch ein dichtes Dach von der AuBenwelt isoliert ist und in einem künstlichen Klima lebt. Die menschlichen Verhältnisse entarten nun immer mehr, bis es zu einem Sturz in das Chaos 
und zur Möglichkeit der "Reinigung" kommt.

Es besteht kein Zweifel, daß die russischen Dichter mit den Gesetzen der Literatur gut genug vertraut waren, um die Gründe für die Unmöglichkeit einer affirmativen Utopie symbolistischer Observanz zu durchschauen.

Fremde Welten und außerirdische Wesenheiten leben in der lyrischen Poesie der Symbolisten als übersinnliche Wahrnehmungen, als poetischer Traum, der - wie V. Ivanov in dem Aufsatz "Granicy iskusstva" [Grenzen der Kunst] sagt - so fein gesponnen ist wie ein Seidenkokon.

Dieser Traum hält aber keinem Experiment stand, ohne daß er sich auflösen müßte, und jede konkrete Vergegenwärtigung wïrde ihn in seine Nachäffung verkehren, in eine groteske Farce. Das "fleischgewordene" oder materialisierte Symbol erweist sich immer als Surrogat, als Fälschung und als Betrug, und auf diesem Prinzip sind schon die frühen lyrischen Dramen A. Bloks aufgebaut.

In jedem dieser Stücke wird ein bestimmter Aspekt der Utopie kritisch analysiert und durch Ironie zerstört. Im ersten Drama, dem "Balagančik" [Schaubude] 1906; an dem Masken und Puppen beteiligt sind, wird die mystische Braut, die in den frühen Gedichten eigentlich das Symbol der Weltseele, der "vselenskaja duša" ist, als "kartonnaja podruga" [Freundin aus Pappe], als "kartonnaja nevesta" [Braut aus Pappe], entlarvt. In der Schaubude der Welt ist sie unter den Menschen, die sich wie "Puppen aus dem ethnographischen Museum" benehmen (kukly iz ètnografičeskogo muzeja), nur ein Stück beklebte Pappe, so wie die Ferne, die hinter dem offenen Fenster lockt, nur bemaltes Papier ist. 
Block verwendet hier noch die traditionellen Figuren aus der "Commedia dell'arte": Colombina, Pierrot, Harlekin, doch wird auch dieses Verfahren von Blok dadurch ironisiert, daß er die Person des Autors im Stück mit auftreten läßt, eines Autors, der versichert, $d a B$ er weder ein Mysterium noch ein Puppenspiel geschrieben habe, sondern ein "realistisches" Drama:

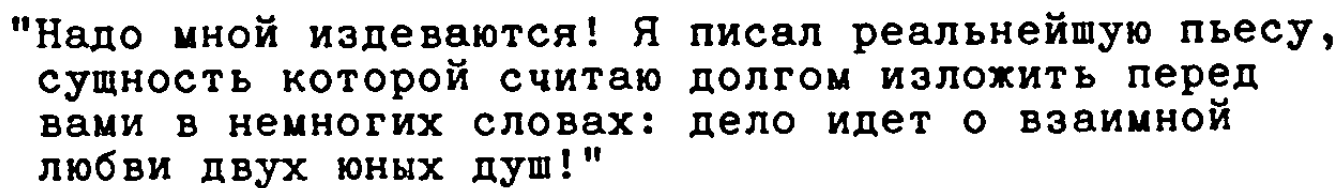

[Man macht sich über mich lustig! Ich habe ein ganz reales Stück geschrieben, dessen Gehalt Ihnen in ein paar Wcrten zu erläutern ich für meine Pflicht halte. Hier geht es um die gegenseitige Liebe zweier junger Seelen!]

In der Figur des Autors erfolgt so die zweite ironische Brechung, als sei gar nicht die mystische Liebe, die Kommunikation mit außerirdischen Wesenheiten parodiert, sondern nur ein bürgerliches Liebesdrama.

In dem zweiten Drama, ebenfalls aus dem Jahr 1906, geht es un die Transformation des Lebens, um die konkrete Befreiung aus irdischer Not. Das Stück, das "Korol' na ploščadi" [Der König auf dem Platz] betitelt ist, trägt groteske utopische Züge, nicht nur dadurch, daß personifizierte Gerüchte (sluchi) auftreten, nicht nur dadurch, daß der Durchschnittsverstand, der sog. "zdravyj smysl" in der Narrenkappe auftritt, sondern vor allem darin, daß der Titelheld des Stückes, der König, stumme Person bleibt; er ist die Figur, um die sich alles dreht, aber in Wirklichkeit ein versteinertes Denkmal, ein Götzenbild, das auf der Terrasse seines Palastes am Meer steht. 
In diesem Drama haben die geisterhaften Schiffe, auf deren Ankunft man die ganze Zeit wartet, die Funktion eines Symbols für Glück und Freiheit übernommen, aber niemand weiB, ob die Schiffe nun wirklich ankommen werden. Das Symbol geht in Bloks Lyrik bis in den Dezember 1904 zurück, auf den Gedichtzyklus "Ee pribytie" [Ihre Ankunft]. Da die Schiffe hier aus der Morgendämmerung auftauchen, unter den "Pfeilen" der Sonnenstrahlen, wird deutlich, daß die Schiffe eine Botschaft aus anderen Welten mitbringen, daß sie wiederum der weiblichen Weltseele, der "vselenskaja duša" verschwistert sind. Darauf deutet ja der Titel "Ee pribytie".

Da:i Drama "Korol' na ploščadi" ist ein utopisches Spiel, -n dem Blok die Illusion von der Transformation des Lebens durch die Königin des Universums und ihre Schiffe ad absurdum führt. Die Hoffnung des Dichters, der als Person in dem Stück auftritt, klammert sich an die Schiffe und an die Tochter des Baumeisters, die "doč' zodčego", in der sich Züge der früheren "Prekrasnaja Dama" und der im gleichen Jahr 1906 auftauchenden "Neznakomka" überlagern, und die am Schluß des Stückes einfach "Ona" genannt wird. Das Ziel, wohin die Tochter des Baumeisters führen will, ist aber keine neue soziale Ordnung, sondern eine "bezumnaja fantazija" [verrückte Phantasie], die Wiedererweckung des versteinerten Königs und seiner uralten Macht. Das ist aber nicht die Umwälzung, auf die die Armen gewartet haben, und während einige Verzückte von der Szene bewegt sind, in der die Tochter des Baumeisters die gigantischen Knie des steinernen Königs umarmt, ertönt der Ruf des Bettlers: "Kebenok umiraet!"[Ein Kind stirbt!] und der Ruf vieler Stimmen: "Chleba! Nas obmanuli! Doloj Korolja! Doloj dvorec!" [Brot! Man hat uns betrogen! Nieder mit dem König! 
Nieder mit dem Hof!] Für die Verschwörer ist das das Zeichen zum Handeln, und es entspinnt sich jetzt die für den späteren Blok typische dissonante Gedankenführung zwischen den Stimmen des Aufruhrs und der sozialen Empörung auf der einen Seite und der jenseitigen Vision des Dichters auf der anderen Seite. Die eine Stimme ist der Schrei nach Brot und die Aufforderung zum Handeln: "Zgite, razrušajte vse, vy ne možete ručat'sja za zavtrašnij den'!"[Brennt nieder, zerstört alles, ihr könnt nicht für den morgigen Tag garantieren!]. Aber dazwischen mischen sich die Rufe: "Korabli prišli! Sčast'e! sčast'e!" [Die Schiffe sind da! Glück! Glück!] Nur ist es jetztzu spät für diese Hoffnung. Hinter dem Dichter, der die Stufen des Palastes emporsteigt, um der Tochter des Baumeisters in diesem feierlichen Augenblick nahe $z u$ sein und auch um die Schiffe zu sehen, drängt bereits die Menge auf den Palast zu. Der Dichter sieht sich dem Himmel der Freiheit nahe und ruft erregt: "Smotri, osypajutsja doždem rakety - lepestki nebesnych roz!" [Schau her, wie Regen sprühen Raketen - Blütenblätter himmlicher Rosen!], und die Tochter des Baumeisters antwortet: "Ty svoboden". [Du bist frei]. In diesem Augenblick aber erfolgt die Katastrophe. Die Menge stürmt die Terrasse des Palastes und unter der Terrasse wackeln bereits die Säulen. Die Terrasse stürzt ein und alle Beteiligten kommen um.

Der kontradiktorische Zusammenhang zwischen der revolutionären Wirklichkeit und der mystischen Rose, der hier nicht frei von Ironie erscheint, ist nur aus der revolutionären Situation des Jahres 1905 zu erklären. In der revolutionären Situation des Winters 1917/18 erneuert sich diese Vision in einem neuen bizarren Bild. Am Schluß des lyrisch-dramatischen Poems "Dvenadcat" [Zwölf] ist es Christus im Kranz aus weißen Rosen, 
mit der blutigen Fahne in der Hand, der sich an die Spitze der Rotgardisten stellt. In dieser letzten dichterischen Anstrengung ist die Utopie wiederhergestellt, die in "Korol" na ploščadi" vom Sturm verweht ist: "Korabli ne pridut. Ich uničtožit burja" [Die Schiffe werden nicht kommen. Es wird sie ein Sturm vernichten]. Die Revolutionäre, die in "Korol" na ploščadi" als glaubenslose Anarchisten gezeigt werden, handeln aus Verzweiflung und darum, weil für sie die Welt leer ist, leer und schrecklich. In ihnen deutet sich das Thema des "Strašnyj mir" [Schreckenswelt] an, das Bloks Lyrik in den Jahren vor dem Weltkrieg seinen Stempel aufgedrückt hat.

Der rote Faden, der sich durch die utopischen Spekulationen der Symbolisten zieht, ist der Untergang der alten Ordnung, der Untergang der alten Herrschaft, aber man muß auch sehr deutlich sagen, daß die mystischen Geheimlehren und okkulten Symbole der Symbolisten keinen tragfähigen Grund für eine affirmative utopische Welt bildeten.

Sehr lehrreich ist im Hinblick auf diese Verhältnisse der Versuch, den Fedor Sologub in seiner Romantrilogie "Tvorimaja legenda" [Eine Legende im Werden] gewagt hat. Das Werk ist in seinen gelungensten Teilen eine sozialkritische Satire und ein parodistisch-pamphletistischer Gesellschaftsroman aus der Zeit der Revolution von 1905. Sologubs Romanheld, Trirodov, der Gutsbesitzer, Pädagoge, Alchimist, Poet und Konstrukteur steht aufder Seite der Ausgebeuteten und Machtlosen, er ist ein liberaler und immer hilfsbereiter Parteigänger der Linken.

Viele philosophische Ansichten der Dekadenten werden in der Trilogie polemisch karikiert und überall, wo Sologub das Mittel der Parodie oder der Groteske anwendet, erhebt sich der Roman auf die Höhe der seriösen Literatur der Zeit. Das 
gilt entsprechend auch für die sozialkritischen Partien des Romans. tberall aber, wo Sologub seine eigene Philosophie in Protagonisten aus Fleisch und Blut verwandelt, sinkt die Darstellung in erheblichem Maße ab. Was sich in Sologubs Lyrik als "böse" Magie oder auch als überraschende Klangschönheit und gestaltete Bildhaftigkeit einprägt, zerfasert im Roman oft zu peinlicher Trivialität und absurder Phantastik.

Sicher kann man den Roman auch als Kommentar zu Sologubs Lyrik lesen, und insofern gibtder Roman für den ideologischen Hintergrund der symbolistischen Kunst manche wertvollen Aufschlüsse. Trirodov ist eine ganze symbolistische Synthese, aber gerade seine dichterische,philosophische, pädagogische, okkultistische, technische und staatsmännische Omnipotenz macht ihn als Romanheld unglaubwïrdig und problematisch. Trirodov hat ganz eingehend beschriebene Beziehungen zu dem Bereich des tbersinnlichen, und er verfügt sogar über den technischen Verstand, ein Weltraumschiff zu bauen, das ihn bei Bedarf in andere Welten bringen kann. Er ist eine Art symbolistischer tbermensch, und der Roman endet damit, daß der russische Dichter zum König eines utopischen Inselreiches gewählt wird, dessen etwas morbide Königin eben in einer großen Katastrophe beim Ausbruch eines Vulkans umgekommen ist. Was Trirodov aus diesem utopischen Land zu machen gedenkt, erfahren wir von Sologub aber leider nicht mehr, weil die Trilogie mit der Ankunft des neuen russischen Königs, der sein Raumfahrzeug zur Reise benutzt hat, endet. Trirodov ist Kosmonaut, und mindestens den Mond kann er mit seinem gläsernen Schiff schon erreichen. Es bleibt sogar offen, ob nicht das Land, das ihn zum König auserkoren hat, auf dem Mond liegt, denn die Krater des Inselvulkans werden von den Wissenschaftlern des 
Landes als Mondkrater angesprochen.

Diese Weltraumphantastik hat Sologub nach eigenen Angaben H.G. Wells zu verdanken, aber Trirodovs Weltraumutopie geht in diesem symbolistischen Roman eine leider doch miBlungene Verbindung mit der astralen Metaphorik und Emblematik der mussischen Symbolisten ein. Diese astralen Gedichte sind zu zahlreich, als daß es nötig wäre, hier auf Parallelen hinzuweisen, die sich fast bei allen Symbolisten finden. Vergessen wir nicht, daß auch Bloks "Neznakomka" [Unbekannte] ein "fallender" Stern ist ("padučaja zvezda"), und daß Kometen, Sterne und Milchstraßen in Bloks Symbolik zeitweilig eine dominierende Rolle spielen.

Eine deutliche Skepsis der ehemaligen Vertreter des Symbolismus gegenüber allzu utopischen Hoffnungen verbreitete sich nach der Revolution. Der Flug zu den Sternen verlor durch den neuen zeitgeschichtlichen Hintergrund gerade für einen Vertreter der utopischen Dichtung wie Sologub seine Perspektiven. In dem schmalen Gedichtband "Koster dorožnyj" [Scheiterhaufen am Weg] (1922) hat Fedor Sologub ein Gedicht abgedruckt, das ich als AbschluB meines Vortrages zitieren möchte, gerade weil wir in diesem Jahr 1969 Zeugen der Eroberung des Mondes geworden sind:

"Взлетающим

Хотя б вы нам и обещали

Завоевание луны,

Но все еще небес скрихали

Для ваших крыл запрещены.

И все еще безумство радо

Ковать томительные сны

Над плитами земного ада

Под гулы тусклой глубины.

И все еще разумной твари

Века неволи суждены -

Томиться в длительном угаре

Всегда схигаемой весны" 
[Den Aufwärtsfliegenden

Wenn ihr uns auch die Eroberung des Mondes versprechen wirdet,

So blieben die Gesetzestafeln des Himmels für eure Flügel doch verboten.

Und weiterhin macht es dem Wahnsinn Freude, bedrückende Träume zu schmieden über den Herdplatten der irdischen Hölle, unter dem Grollen der trüben Tiefe.

Und weiterhin sind dem vernunftbegabten Geschöpf

Zeiten der Unfreiheit verheiBen - des schmerzlichen Leidens

im anhaltenden Branddunst des stets der Verbrennung überantworteten Frühlings.]

B e 1 y $j$, Andrej: Apokalipsis v russkoj poézii. In: Vesy, $1905,4$.

B e 1 y $j$, Andrej: Chimery. In: Vesy, 1905, 6.

B $1 \circ \mathrm{k}$, Aleksandr: Polnoe sobranie sočinenij $\mathrm{v}$ vos'mi tomach, I - IV, Moskva-Leningrad 1960 - 1961.

B r j u s o v, Valerij: Ključi tajn. In: Vesy, 1904, 1.

B $r$ j u s o v, Valerij: Izbrannye sočinenija $v$ dvuch tomach, I, Moskva 1955.

F o f a nov, K.M.: Stichotvorenija i poemy. BP (b. ser.). M.-L. 1962 .

I v a n o v, Vjačeslav: Granicy iskusstva. In: V. Ivanov, Borozdy i meži. Moskva 1916.

I v a n o v, Vjačeslav: Prozračnost'. Nachdruck der Moskauer Ausgabe von 1904 mit einer Einleitung von Johannes Holthusen. Slavische Propyläen 30. Munchen 1967.

$M$ a $t h$ a u $s$ e $r$, Zeněk: Symbolismus. In: $Z$. Mathauser, Die Kunst der Poesie. Stufen, die zur Oktober-Dichtung hinführten. Prag 1967 (Artia).

$S \circ 1 \circ g$ u b, Fedor: Tvorimaja legenda. Nachdruck der Bände XVIII-XX der Gesamtausgabe der Werke Sologubs. St. Petersburg 1914, mit einer Einleitung von Johannes Holthusen. Slavische Propyläen 125. München 1972.

S $\circ ~ I \circ$ \& u b, Fedor: Koster dorožnyj. Moskva-Petrograd 1922. $\mathrm{V}$ e $\mathrm{r} l$ a $\mathrm{i}$ n e, Paul: Fêtes galantes. Jadis et naguère. (Bibliothèque de Cluny. 29.) Paris 1954. 


$\frac{\text { Problemederfrüen }}{\frac{\text { sowjetliteratura }}{\text { (Prosa, Drama) }}}$

Thema dieses Vortrages über Probleme der russischen Sowjetliteratur sollen die Anfänge dieser Literatur nach der Revolution im Oktober 1917 sein, also eine Zeit, die schon gut 50 Jahre zurückilegt.

Unsere Fragestellung soll folgende Punkte umfassen:

1. Periodisierungsprobleme,

2. das Problem der Einwirkung der politischen und gesellschaftlichen Wirklichkeit,

3. das Problem der ästhetischen und literarischen Norm in der Evolution der russischen Literatur zwischen 1918 und 1923,

4. das Problem der literarischen Gattungen.

Das Problem der Periodisierung taucht schon im Zusammenhang mit der Benennung der russischen Literatur als "Sowjetliteratur" auf; von wann an gibt es eine Sowjetliteratur, ist etwa Bloks dramatische Verserzählung "Dvenadcat' [Zwölf] ein Werk der Sowjetliteratur, weil es im Januar 1918 entstanden ist und weil in ihm die "Roten" die Helden sind? Die Antwort auf diese letzte Frage fällt sehr oft positiv aus, d.h. es wird in der Literaturgeschichtsschreibung sowohl mit dem politischen Freund-Feind-Schema gearbeitet, als auch mit dem auf historische Ereignisse bezogenen Periodenabschnitt. Beide

(Der Vortrag wurde erstmalig gehalten an der Universität Wien, am 16.3.1971.) 
Kriterien sind indessen extraliterarischer Provenienz, und das ist bei einer ganzen Reihe von Periodisierungskriterien bekanntlich die Regel. Das literarhistorische Problem wird erst durch die Tatsache umrissen, daß der alle gleichzeitigen Erscheinungen prägende Augenblick eine "chronologische Fiktion" ist, wie es Hans Robert Jauss in seiner Konstanzer Programmschrift "Literaturgeschichte als Provokation der Literaturwissenschaft" (1967) näher ausgeführt hat. Man muß also mit dem Faktum der "Ungleichzeitigkeit des Gleichzeitigen" rechnen oder - wie Jauss sagt - damit, daß "die gleichzeitig erscheinende Literatur - produktionsästhetisch gesehen - in eine heterogene Vielfalt des Ungleichzeitigen" zerfällt.

Persönlich glaube ich, daß neue literarische Perioden sehr oft dadurch eingeleitet werden, daß bestimmte literarische "Generationen" in der Luft liegende Probleme aufgreifen, an sich reißen und auf eine zeittypische Weise lösen. Das Zeitbewußtsein erfährt so eine deutliche Prägung, weit über die Grenzen einer Schule oder einer Strömung hinaus, und die Einstellung des Lesers auf ein neues Bedeutungssystem, auf neue Spielregeln, auf einen neuen "Code" wird nach und nach bewerkstelligt.

Die tbergangszeiten, die Interferenzzonen mit anderen folgenreichen Anstößen und Umwertungen auf ganz anderen Gebieten der Kunst führen dabei oft $z u$ einem äußerst komplizierten System der Literatur, das sich jeder Etikettierung entzieht. Hier kann nur die unbefangene Betrachtung Ordnung schaffen, eine ästhetisch-typologische Betrachtung, die ihrerseits in die Diachronie hineinleuchtet, die aber auch die Entwicklung auf anderen Gebieten der künstlerischen Betätigung im Auge behält. 
Die Jahre 1908-12 werden in RuBland zu einem Epocheneinschnitt, weil der Panästhetizismus der Symbolisten auf der einen Seite die formale Reaktion des Futurismus und des Abstraktionismus hervorruft, und weil auf der anderen Seite die Probleme der Gesellschaft und der Beziehung zwischen Volk und Intelligenz virulent werden, z.B. im Werk von A. Blok und in den Strömungen des' sog. "mystischen Anarchismus". Diese Bewegungen treten in der Sowjetliteratur Anfang der 20er Jahre in einen inneren Zusammenhang, der mir noch ungenügend aufgehellt scheint. Als Bindeglied kann man die Gruppe der sog. "Skythen" ansehen, die von der "kosmischen Revolution" träumten und die in R. Ivanov-Razumnik seit etwa 1914 ihren theoretischen Kopf fanden. Dieser Gruppe (den "Skythen") standen 1917/18 Schriftsteller wie Remizov, Belyj, Prišvin, Esenin, Kljuev und Zamjatin nahe. Gemeinsam ist ihnen allen der antibürgerliche Affekt, die Sympathie für die soziale Revolution und das Pathos der Befreiung von ästhetischen Fesseln. Weithin wird die Regression in Richtung auf ursprüngliche Befindlichkeiten des Menschen angestrebt, die Rückkehr zu primitivistischer Abstraktion in der Malerei, zu primitivistischen und zoomorphisierenden Metaphern in der Sprache; ich erinnere an Majakovskijs Gedichtband "Prostoe kak myčanie" [So einfach wie das Brüllen], 1916.

Ivanov-Razumnik schrieb 1920 über Aleksandr Gercen, den er einen "Skythen der 40er Jahre" nannte:

\footnotetext{
"Варвары спокон века отличались тонким зрением; нам Геродот делает особую честь, говоря, что у нас гла32 ящерицы... Варварство, скифство, неумение прочно и твердо строить жизнь! Конечно. И, повторяю, В зтом слабость, но в этом и сила."
} 
[Die Barbaren zeichneten sich von jeher durch scharfen Blick aus; Herodot erweist uns besondere Fhre, indem er sagt, wir hätten die Augen von Eidechsen. ... Barbarentum, Skythentum, Unfähigkeit, das Leben dauerhaft und fest $z u$ erbauen! Natürlich. Und, ich wiederhole, darin besteht die Schwäche, aber darin besteht auch die Stärke.]

Die beiden Almanache "Skify" [Skythen] erschienen 1917 und 1918, herausgegeben von Ivanov-Razumnik, sie wandten sich gegen das intellektuelle Kleinbürgertum im Namen einer neuen heidnischen Weltanschauung, aber zweifellos kann man diese Publikationen nicht zur Sowjetliteratur rechnen, ebenso wenig wie Bloks Gedicht "Skify" (1918) oder die von Ivanov-Razumnik begeistert begrüBten "Dvenadcat". Diese Literatur setzte einfach eine ältere Entwicklungslinie fort, die "antiapollinisch", d.h. dionysisch und anarchistisch eingefärbt war.

Zwischen 1918 und 1922 erfolgte in dem neuen Sowjetstaat eine Scheidung der Geister, eine Abklärung der Positionen, die dann durch die Austreibung eines Teiles der Intelligenz 1922 stark beschleunigt wurde. Von einer eigentlichen Sowjetliteratur, die praktisch erst in den Bürgerkriegsjahren entstand, kann allenfalls von 1921 an gesprochen werden; formiert erscheint sie erst 1923 in den deutlich voneinander abgegrenzten Gruppen "Pereval" [Ubergang], "Lef" [Linke Front der Künste] und den proletarischen Assoziationen VAPP [Allunions-Assoziation proletarischer Schriftsteller], MAPP [Moskauer Assoziation proletarischer Schriftsteller], später (1925) RAPP [Russische Assoziation proletarischer Schriftsteller]. Einzelne proletarische Gruppierungen wie "Kuznica" [Schmiede] (gegründet 1920) und die Proletkul't-Zirkel sind zwar früher entstanden, doch bleiben sie zunächst für die russische Literatur untypisch. Für das Gebiet der Prosa konnte Zamjatin noch 1923 in seiner tbersicht "Novaja russkaja proza" [Neue 
russische Prosa] erklären, die proletarischen "Inkubatoren" hätten noch keinen Erzähler hervorgebracht, der auch nur durch die Hintertür in die Geschichte der Literatur eingehen könnte.

Aus allen diesen Gründen sind die Jahre zwischen 1918 und 1923 die eigentlich entscheidenden für die Entstehung der Sowjetliteratur, und wir wollen uns gerade diesem Zeitabschnitt zuwenden. Die politische und gesellschaftliche Wirklichkeit dieser Jahre konnte auf sehr verschiedene Weise auf die Literatur einwirken. Zunächst ganz handfest durch die Schließung von Zeitschriften und Verlagen, durch den Mangel an Papier und durch die jahrelangen Kriegshandlungen im Land. Ein Teil der Verleger versuchte - übrigens mit gar nicht geringem Erfolg im Ausland (vor allem Berlin) weiterzudrucken und auch für den russischen Markt tätig zu sein. Im ganzen kam es aber doch zu einem steilen Abfall der Buchproduktion.

Von der Lebensweise der Intellektuellen während des Bürgerkrieges etwa in Petersburg vermitteln nicht nur die Gedichte von Mandel'štam, die Erzählungen von Isaak Babel' und von Evgenij Zamjatin ein krasses Bild, auch Viktor Sklovskij hat für die russischen Leser im Ausland in sein Buch "Chod konja" [Rösselsprung], das 1923 in Berlin erschien, eine realistische Schilderung unter dem Titel "Peterbirrg v blokade" [Petersburg während der Blockade] aufgenommen, die mit einer Apotheose der Revolution ausklingt:

"Я понимаю тех, кто бился у подступа к Петрограду и отбил его. В городе, истошенном до тла, было тепло и жар горячечного больного. Город был болен великой болезнью - революцией. Этот умирающий Петербург не стал провинциальным, ипущие от него таяли от его хара. Немногие знали о том, что они горят, но многие горели. 
Старая жизнь кончилась и мы в пустыне. Я не зна10, куда я иду, но назадя не хочу.Я научился дорохить пройденным. Умерла старая семья. Мы разлюбили свои вещи. Мы забыли свои старые места. Слишком трудно будет возвраматься.

Город пуст. Как будто улицы подмыли берега так расширились они. Но город все еще жив и горит не то, как огонь, не то, как рана на теле сельской России. Красный огонь революции - последнее, что осталось от города в России."

[Ich verstehe alle, die im Vorgelände von Petersburg kämpften und es entsetzten. Die völlig erschopfte Stadt glühte wie ein Fieberkranker, sie litt an einer großen Krankheit - an der Revolution. Dieses sterbende Petersburg wurde nicht provinziell, die von dorther kamen, wurden von seiner Glut verzehrt. Nur wenige wußten, daß sie glühten, aber viele glühten.

Das alte Leben ist $z u$ Ende, und wir sind in einer Wüste. Ich weiß nicht, wohin ich gehe, aber zurick will ich nicht. Ich habe das Erlebte schätzen gelernt. Die alte Familie ist tot. Wir lieben unsere alten Sachen nicht mehr, wir haben unsere alten Orte vergessen. Eine Rückkehr ist zu schwierig. Die stadt ist leer. Die Straßen scheinen so breit, als seien sie über die Ufer getreten. Aber die Stadt lebt noch immer, sie brennt wie ein Feuer oder wie eine Wunde am Körper des ländlichen Rußland. Das rote Feuer der Revolution ist das letzte, was von der russischen Stadt übriggeblieben ist.]

Thematisch ist an der Literatur zwischen 1918 und 1923

interessant, daß die gesellschaftliche und die politische Situation vor allem in zwei verschiedenen Vorstellungsreihen verarbeitet wird. Vor dem heimischen Hintergrund dominieren die nackten menschlichen Probleme: das Uberleben in der Not, das Verhalten des Menschen zum Menschen, der Kampf um Lebensmittel und Brennholz, Hunger, Wunden, Schmutz, Läuse, Verfall, Krankheit, Tod. Die eigentlichen gesellschaftlichen Probleme werden durch die Agonie der Volkswirtschaft und durch den direkten Kampf ums Dasein verarängt. Politische Fragen und gesellschaftliche Widersprüche werden in völlig anderen Kontex- 
ten abgehandelt, sie werden einfach in zeitlich oder räumlich ferne Umgebung verlegt.

Gor'kij z.B. schreibt in diesen Jahren an seiner Lebenstrilogie (der dritte Band "Moi universitety" [Meine Universitäten] erscheint 1923) und veröffentlicht seine Erinnerungen an Tolstoj (1919). Zamjatins soziale Satire gilt England ("Ostrovitjane" [Insulaner] und "Lovec Łelovekov" [Der Menschenfänger] 1918) und sein gesellschaftskritischer Roman "My" [Wir] ist in einer utopischen Welt angesiedelt (1920-2l). Viel auffälliger ist aber noch die Flucht aus der russischen Aktualität im Drama. Vasilij Kamenskijs "Sten'ka Razin" (1919) spielt im 17. Jahrhundert, Vladimir Vol'kenštejns Tragödie "Spartak" [Spartakus] (1920) ist ein historisches Drama aus dem alten Rom, das Drama "Ogni svjatogo Dominika" [Die Feuer des heiligen Domenicus] von Zamjatin (1922) spielt in Spanien, in der Zeit der Inquisition, das Agitationsstück "Slyšiš' Moskva?!" [Hörst du Moskau?!] (1923)von Sergej Tret'jakov spielt in Deutschland. Das sozialistische Milieudrama eroberte sich erst mit Tret'jakovs "Gasmasken" (Protivogazy) 1924 unter Eisensteins Regie die Bühne, und das Bürgerkriegsdrama folgte 1927 mit Bulgakovs "Dni Turbingch" [Die Tage der Turbins], der Bühnenversion seines Romans "Belaja gvardija" [Weiße Garde] von 1924, und mit Vsevolod Ivanovs "Bronepoezd 14-69" [Panzerzug 14-69] ebenfalls der dramatisierten Version seines Romans. Auch die Dramen von Lev Lunc (1923 gedruckt) spielen im Auslard ("Vne zakona" [AuBerhalb des Gesetzes] und 'Bertran de Born'). Das russische Theater hatte eigentlich außer Majakovskijs "Misterija-buff" [Mysterium-Buffo] und außer dem Massentheater unter freiem Himmel mehrere Jahre lang kaum eine direkte Beziehung zur Revolution. Viktor Sklorskijs Feuilletons über die Theatersitua- 
tion in den Jahren 1919-21, die in dem Buch "Chod konja" zu finden sind, beklagen laut die Schalheit und die entmutigende Zurückgebliebenheit des Repertoires. In dem Artikel "Kruževennoe varenie" [Stachelbeermarmelade] sagt Sklovskij:
"Очевидно, у наших театралов большой запас кружевен- ного варенья. Вещи, которые ставятся в театре, хо- рошие веши, с репутацией, но все это так давно сва- рено... Великий театр будет театром не крухевенного варенья, а театром вот сейчас созданного репертуара."
[Offensichtlich haben unsere Theater einen großen Vorrat an Stachelbeermarmelade. Die Sachen, die im Theater gegeben werden, sind gute Sachen, reputier- lich, aber das alles ist schon vor so langer Zeit gekocht worden ... Großes Theater wird nicht ein Theater der Stachelbeermarmelade sein, sondern ein Theater des ad hoc geschaffenen Repertoires.]

Sklovskij empfiehlt hier in Ermangelung neuerer Stücke, wenigstens einmal etwas von Chlebnikov oder wieder Majakovskijs "Misterija-buff" aufzuführen, ein Stück, das an echter Volkstümlichkeit alles überrage, was die Revolution bisher geschaffen habe. Das ist vor der Renaissance der Theatertechnik und des russischen Repertoires geschrieben, die sich in den Jahren 1922-23 abzeichnet, und die Regisseuren wie Meyerhold und Eisenstein $z u$ verdanken ist, sowie Autoren wie Tret'jakov und - später in den zwanziger Jahren - erneut Majakovskij, sowie Bulgakov, Oleša und anderen.

In der erzählenden Prosa, vor allem bei Pil'njak, Babel' und natürlich bei den "Serapionsbrüdern"macht sich die russische aktuelle Thematik einige Jahre früher geltend, und wenn auch viele Autoren ihre Unabhängigkeit von den Anforderungen der Zeit gern ausdrücklich unterstrichen, ist hier doch der Zusammenhang mit der außerliterarischen Entwicklung und mit dem Leben und Fühlen aller Bürger ohne weiteres gegeben. 
Das Problem der literarischen und ästhetischen Normen in den Jahren zwischen 1918 und 1923 wird naturgemäB durch die politischen Fragestellungen stark kompliziert. In dem Buch "Chod konja" schreibt Viktor Sklovskij in dem Abschnitt "Ob iskusstve i revoljucii" [trber Kunst und Revolution]:

\begin{abstract}
"То, что я пишу сейчас, я пишу с чувством великого дружелюбия к людям, с которыми я спорю. Но ошибки, делаемые сейчас, так явны для меня и будут так тягостны для искусства, что их нельзя замалчивать. Найболее тяжелой ошибкой современных писателей об искусстве я считаю то уравнение мехду социальной революцией и революцией форм искусства, которое сейчас они доказывают. 'Скифы ', 'Футуристы-коммунисты', 'пролеткульты' - все провозглашают и долбят одно и тоже: новому миру, новой классовой идеологии должно соответствовать новое искусство."
\end{abstract}

[Das, was ich jetzt schreibe, schreibe ich mit dem Gefühl großer Freundschaft für die Menschen mit denen ich streite. Aber die Fehler, die jetzt gemacht werden, sind so offenkundig für mich und werden so schwerwiegend für die Kunst sein, daß man sie nicht verschweigen kann. Der schwerste Fehler derjenigen, die heute über Kunst schreiben, ist meiner Meinung nach die Gleichung zwischen der sozialen Revolution und der Revolution der Formen der Kunst, die sie jetzt zu beweisen suchen. Die "Skythen", die "Futuristen-Kommunisten", die "Proletkulte" - sie alle proklamieren und hämmern uns ein: der neuen welt, der neuen Klassenideologie muB eine neue Kunst entsprechen.]

Allen diesen Beweisen, so meint Sklovskij, ist gemeinsam, daB sie davon ausgehen, neue Lebensformen müBten neue Kunstformen erzeugen. Die Beweise sind aber, wie Sklovskij hervorhebt, dïnn, und die Kunst - so sagt er hier sehr scharf braucht sich ebensowenig um einen Platz in der sozialen Revolution $z u$ bemühen, wie das Sonnenlicht um eine Wohnung am Nevskij Prospekt mit drei Zimmern und Bad.

Die Dialektik von Form und Inhalt formuliert Sklovskij hier polemisch in dem einen Satz: "Die neue Form ist es, die den neuen Inhalt hervorbringt." 
"Ведь мы раскрепостили искусство от бита, который играет в творчестве лишь роль при заполнении форм...

Но Футуристы только осознали работу веков. Искусство всегдабыло вольно от хизни, и на цвете его никогда не отрахался цвет флага над крепостью города."

[Wir haben doch die Kunst vom Milieu emanzipiert, das für den SchaffensprozeB nur eine Rolle bei der Ausfüllung der Formen spielt. ... Die Futuristen haben nur die Arbeit der Jahrhunderte bewuBt gemacht. Die Kunst war immer frei vom Leben, und ihre Farbe hat nie die Farbe der Fahne über der Zitadelle der Stadt widergespiegelt.]

Außerungen des jungen Majakovskij und anderer "Kubo-Futuristen" scheinen dieser Meinung beizupflichten, und tatsächlich hat sich die ästhetische Diskussion der damaligen Zeit zwischen dem Absolutheitsanspruch der Kunst als ständiger Avantgarde und der klassenbewußten proletarischen Auffassung abgespielt.

Interessant ist, daß sich gerade die beiden "Iinken" Gruppierungen der kleinbürgerlichen Einstellung verdächtigen. 1918, in seiner Einleitung zu dem Sammelband "Ržanoe slovo" [Worte wie Schwarzbrot] gibt Majakovskij seine Vorstellung vom Wandel der ästhetischen Normen wieder:

\footnotetext{
"Мы прорвали любовный шопот засамоваренных веранд тысяченогим шагом столетий. Это наши размеры - какофония войн и революций.

И не наша вина, если и сейчас благородные чувства гражданских позтов забронированы в такие эпитеты, как 'царица свобода', 'золотой труд' - у нас давно царицы и золоты сменены хелезом, бунтом."
}

[Wir haben das Liebesgeflüster der Samowarveranden durch den tausendfüßigen Schritt der Jahrhunderte unterbrochen. Das sind unsere Maßstäbe: die Kakophonie der Kriege und Revolutionen. Und es ist nicht unsere Schuld, daß noch heute die anständigen Gefühle demokratischer Dichter sich in solche Epitheta gürten wie 'Königin der Freiheit', 'goldene Arbeit' - wir haben längst die Königinnen und das Gold durch Eisen und Aufstand ersetzt.J 
Majakov8kij stellt bis 1918 noch immer die Durchbrechung der literarischen Norm in den Vordergmund, den "Sturm auf das poetische Arsenal", wie er metaphorisch sagt, freilich ohne politische Implikationen zu leugnen oder zu vertuschen.

Wir wollen hier auf den Lyriker Majakovskij und auf die futuristische Lyrik nicht näher eingehen, einmal aus Zeitgründen, und dann auch deshalb, weil die Normen der Lyrik bereits kurz vor dem Weltkrieg einem AuflösungsprozeB unterlagen, an dem Symbolisten wie Belyj und Blok schon mitbeteiligt waren. Neue Normen hatten ihren Anspruch geltend gemacht, und ein noch eindeutigeres zeittypisches Bild ergibt sich bei der Betrachtung der suprematistischen und kubistischen Malerei sowie der Gegenreliefs und Collagen von Tatlin. Hier wurden neue ästhetische Vorstellungen ins Werk gesetzt, die nach Anwendung auch in der Dichtung strebten.

Das Theater war teils auf halbem Wege zum epischen Theater stehengeblieben (Bloks "Pesnja sud'by" [Schicksalslied] und die Dramen Leonid Andreevs oder Gor'kijs), teils aber auch zum sprachlichen Experimentierfeld geworden wie im futuristischen Drama Chlebnikovs und in der berühmten futuristischen Oper "Pobeda nad solncem" [Sieg über die Sonne], die zwei bekannte Maler zum Entwurf von Kostümen und Dekorationen gereizt hat: Kazimir Malevič bei der ersten Aufführung in Petersburg 1913, und später den Konstruktivisten El Lisickij, der 1923 in Hannover die Figurinenmappe "Die plastische Gestal tung der elektromechanischen Schau 'Sieg über die Sonne' (als Oper gedichtet von A. Krutschonich, Moskau 1913)" edierte. Es kann keinen Zweifel daran geben, daß sich Malerei, Plastik und Literatur in den Jahren zwischen etwa 1911 und 1925, in den Jahren des Kubismus, des Suprematismus und des 
Konstruktivismus in RuBland gegenseitig beeinflußt haben. Das liegt einmal an der engen persönlichen Bekanntschaft und Zusammenarbeit von Dichtern und Malern in den Zirkeln der Futuristen, aber auch daran, daB es dichtende Maler gab wie z.B. David Burljuk, der zum ersten wichtigen Anreger für den ganz jungen Majakovskij werden sollte. Eine ähnliche DichterMaler-Beziehung ist auch die Freundschaft zwischen Evgenij Zamjatin und Jurij Annenkov, dem interessanten russischen Graphiker, der zeitweilig dem Kubismus nahestand. Zamjatin hat 1922 eine seiner wichtigsten theoretischen Abhandlungen über Annenkov geschrieben, unter dem Titel "O sintetizme" [Uber den Synthetismus]. Zamjatin sieht hier die dialektische Entwicklung der künste und ihrer ästhetischen Normen in einer Spirale, die wie eine Wendeltreppe in den babylonischen Turm führt. Eine ähnliche Spirale hat aber auch Vladimir Tatlin in seinem Denkmal für die Dritte Internationale dargestellt, das Viktor Sklovskij in "Chod konja" detailliert beschrieben hat.

Die Künste sieht Zamjatin jeweils durch einen Plus- und einen Minuspol gehen, wobei der Pluspol in der Xsthetik für den Materialismus, für Moleschott, Büchner, Rubens, Repin, Zola, Tolstoj, Gor'kij, den Realismus und den Naturalismus steht, während der Minuspol Schopenhauer, Botticelli, Rossetti Vrubel', Verlaine, Blok, den Idealismus und den Symboiismus bezeichnet. $\mathrm{Zu}$ modernen Synthesen kommt es - wie Zamjatin meint - im Werk von Nietzsche, Whitman, Gauguin, Seurat, Picasso. Jeder aber, der in der "heutigen" Kunst arbeitet, so betont Zamjatin, strebt nach Ausgleich, gleichgültig ob dieser nun "Neo-Realismus" oder "Synthetismus" genannt werden soll. 
"Завтра нас не будет. Завтра пойдет новый круг, Адам снова начнет свой худохественный опыт: это история искусства."

[Morgen werden wir nicht mehr sein. Morgen wird ein neuer Kreis angefangen, Adam wird von neuem sein künstlerisches Experiment beginnen: Das ist die Geschichte der Kunst.]

Dabei ist interessant, daß Zamjatin, dessen frühen Stil sein Freund Jurij Annenkov seinerseits als "eine Art literarischen Kubismus" bezeichnete, bedeutend weniger radikal dachte als die Futuristen, über die er in dem Artikel "O sintetizme" schreibt:

"Гинденбург искусства дал им задание бесчеловечное, в котором они должны были погибнуть все до единоro: это задание логическое доведение до нелепости. Они выголнили это лихо, геройски, честно; отечество их не забудет. Они устлали собою землю под жестокий смех, но эта жертва не пропала даром: кубизм, супрематизм, 'беспредметное искусство' - были нухны, чтобы увидеть, куда не следует итти, чтобы узнать, что прячется 3 а той чертой, какую переступили герои."

[Ein Hindenburg der Kunst hat ihnen eine unmenschliche Aufgabe gestellt, an der sie bis auf den letzten Mann untergehen muBten: diese Aufgabe war, das Absurde logisch herbeizuführen. Sie haben das heroisch und ehrlich zu Ende geführt; das Vaterland wird sie nicht vergessen. Sie haben unter grausamem Lachen die Erde mit ihren eigenen Leibern gepflastert, aber dieses Opfer war nicht umsonst: der Kubismus, der Suprematismus, die "gegenstandslose Kunst" - sie waren nötig um $z u$ begreifen, wohin man nicht gehen sollte, um zu erfahren ${ }_{2}$ was sich hinter der Linie verbirgt, die die Helden überschritten haben.]

Die Zukunft sieht Zamjatin nicht durch die Rückkehr zum sog. kritischen Realismus markiert, sondern durch die Anwendung 
eines "komplizierten" Prismas, das groteske Aquivalenzen zwischen Makrokosmos und Mikrokosmos herstellt:

"Открывается, что человек - это вселенная, где солнце - атом, планеты - молекулы, ... открывается, что зеиля - лейкоцит, Орион - только уродливая родинка на губе, и лет солнечной системы к Геркулесу - это только космическая перистальтика кишек. Открывается красота полена - и трупное безобразие луны; открывается - ничтохнейшее, грандиознейшее величие человека; открывается относительность всего...

В наши дни единственная фантастика - это вчерашняя жизнь на прочных китах."

[Nan macht die Entdeckung, daß der Mensch ein Universum ist, wo die Sonne ein Atom, die Planeten Molekule sind ...man macht die Entdeckung, daß die Erde ein Leukozyt, Orion nur eine häßliche Warze auf der Lippe und der Flug des Sonnensystems zum Herkules nur eine kosmische Peristaltik der Gedärme ist. Entdeckt wird die Schönheit eines Holzscheites und die leichenhafte HäBlichkeit des Mondes, entdeckt wird die allerunbedeutendste und die grandioseste Größe des Menschen, entdeckt wird die Relativität von allem ... In unseren Tagen ist die einzige Phantastik - das gestrige Leben auf soliden Grundfesten.]

Die künstlerische Methode, die sich hinter Zamjatins "Synthetismus" verbirgt, ist die Verbindung von räumlich und zeitlich entfernten Vorstellungsreihen, der Kontrast zwischen unendlich kleinen und uneadlich großen Begriffen, nicht die Gegenstandslosigkeit, sondern die groteske oder absurde Montage scheinbar unvereinbarer Maßstäbe. "Die Tür zu dieser Methode", schreibt Zamjatin, "haben die Futuristen eingeschlagen, um den Preis ihrer Köpfe". Zamjatin sah den Unterschied zwischen der Methode der Futuristen und der Technik, die er selbst an die jüngeren Schriftsteller weiterzugeben suchte, nämlich als Kursusleiter am Petersburger "Dom iskusstv" [Haus der Künste] (1921), darin, daß er seine Methode "integral" nannte, im Gegensatz zur "Vergötterung des Differentials" bei den Futuristen: 


\begin{abstract}
"Синтетизи пользуется интегральным смещением планов. Здесь вставленние в одну пространственно-временную раму куски мира - никогда не случайны; они скованы синтезом, и блихе или дальше - но лучи от зтих кусков непременно сходятся в одной точке, из кусков - всегда целое."
\end{abstract}

[Der Synthetismus bedient sich der integralen Verschiebung der Ebenen. Hier sind die in einen raumzeitlichen Rahmen eingefügten Stücke der Welt nie zufällig, sie werden durch eine Synthese zusammengehalten, und näher oder weiter weg - die Strahlen von diesen Stücken treffen sich unbedingt in einem Punkt. Aus den Stücken ergibt sich immer das Ganze.]

Es ist, glaube ich, nicht besonders störend, daß Zamjatin, der selbst Schiffsbauingenieur und Statiker war, die Dinge der Kunst immer etwas simplifiziert hat. Die junge sowjetische Bürgerkriegsprosa basiert genau auf den ästhetischen Prinzipien, die Zamjatin in seiner Abhandlung über den Synthetismus beschreibt, und die Faszinationskraft, die noch heute von den Erzählungen aus der ersten Hälfte der zwanziger Jahre ausgeht, beruht weitgehend auf der Vereinigung des Unvereinbaren, auf der Synthese von lebenswarmem Milieu und abstraktem Phantasma, von Biologie und Kosmologie, von Zoomorphisierung des Menschen und Anthropomorphisierung der Maschine, des Krieges und schlieBlich des ganzen kosmischen Geschehens. Erzähltechnisch bedeutet diese kontrastierende und gebrochene Darstellungsweise, die Zamjatin "smeščenie planov $v$ prostranstve $i$ vremeni" [Verschiebung der Ebenen in Raum und Zeit] nennt, eine Aufteilung in Erzählsegmente mit ständig wechselnder Funktionalisierung der Sprache, wechselnder Perspektive und wechselnder pragmatischer Bedeutung für das Sujet.

Die sogenannte "Sujetlosigkeit" der Erzählung ist, wo sie angetroffen wird, durch ein tberwiegen von Erzählsegmenten mit 
abgeschwächter oder fehlender Bindung an das Sujet zu erklären. Ebenso steht es natürlich auch mit der Erzählung "ohne Helden", die Zamjatin bei Pil'njak frîh als typisch erkannte. Unter Umständen ergeben sich bei der kontrastierenden Komposition der einzelnen Segmente sogar Analogien zur Photomontage und zur Collage, die damals für die ästhetische Wahrnehmung größere Bedeutung erlangte. Daß damit auch das Autor Leser - Verhältnis tangiert wurde, hat Zamjatin ganz klar ausgesprochen (wiederum in "Sintetizm"):

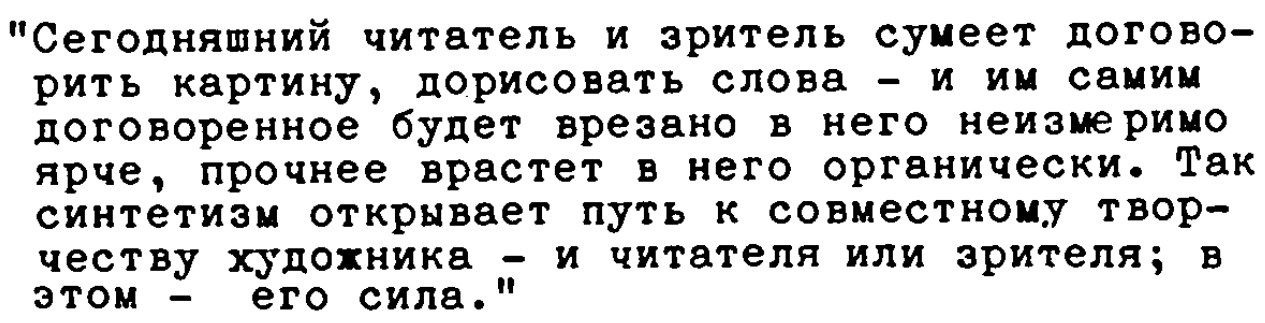

[Der heutige Leser und auch Betrachter lernt es, ein Bild zu Ende zu erzählen und Wörter zu Ende zu zeichnen, und damit wird das zu Ende Erzählte ihm viel deutlicher eingeprägt bleiben und organisch viel fester verwurzelt sein. So eröffnet der Synthetismus den Weg zum gemeinsamen Schaffen des Kunstlers und des Lesers oder Betrachters. Darin liegt seine Stärke.]

Die Kontraste, von denen ich sprach, können natürlich auch in der Semantik des einzelnen Ausdrucks beschlossen sein, beispielsweise in der Metapher oder im Vergleich. Der Gebrauch der Metapher und des ungewohnten Vergleichs wird in der frühen Sowjetliteratur sehr aktiviẹt, meistens aber gerade polemisch im Sinn der Durchbrechung der überlieferten ästhetischen Norm.

Da Anfang und Ende einer Geschichte als Grenzen des Werkes besondere strukturelle Bedeutung haben, spielt die Landschaft als statisches Segment eine große Rolle bei der In- 
tegration der übrigen Segmente. Zamjatin selbst hat in seinen Erzählungen des Jahres 1918 hier die gültigen Vorbilder gegeben, und ich möchte, da unsere Zeit leider begrenzt ist, nur ein paar Anfänge, die in ihrer metaphorischen Enthüllung der verschiedenen Ebenen sehr charakteristisch sind, nebeneinander stellen.

Die satirische Erzählung "Lovec čelovekov" [Der Menschenfänger] setzt mit der Beschreibung des Schauplatzes, des -ebeligen London, ein:

\begin{abstract}
"Розово-молочный, зажмурясь, Лондон плыл - все равно куда. Легкие колонны друидских храмов - вчера еше заводские трубы. Воздущно-чугунные дуги виадуков: мосты с неведомого острова на неведомый остров. Выгнутые шеи допотопно-огромных черных лебедейкранов: сейчас нырнут за добычей на дно. Вспугнутые, выплеснулись к солнцу звонкие золотые буквы: 'Роллс-Ройс, авто' - и потухли. Опять - тихим, смутным кругом: кружево затонувших башен, колыхающаяся паутина проволок, медленный хоровод на ходу дремлюших черепах-домов. И неподвижной осью: гигантский каменный фаллос Трафальгарской колонны."
\end{abstract}

[Rosa-milchig, blinzelnd, schwamm London - ganz egal wohin. Leichte Säulen von Druiden-Tempeln, - gestern noch Fabrikschornsteine. Luftig-gußeiserne Bögen von Viadukten: Brücken von einer unbekannten Insel zu einer unbekannten Insel. Gekrümmte Hälse vorsintflutlich-riesenhafter Schwanenkräne: gleich wïrden sie nach einer Beute auf den Grund tauchen. Erschreckt sprudelten der Sonne klingende goldene Buchstaben entgegen: 'Rolls-Royce Auto' und verloschen wieder. Und von neuem - als ein stiller, undeutlicher Kreis: Geflecht versunkener Türme, schwankender Spinnweben von Drähten, der langsame Reigen der im Gehen schlafenden Schildkröten, - der Hauser. Und als bewegliche Achse: der gigantische steinerne Fhallos der Trafalgar-Säule.J

Die Zoomorphisierung zusammen mit der Regression in längst vergangene Zeiten ("Druidensäulen", "vorsintflutliche Schwäne") erinnert an die futuristische verserzählung "Zuravl'" 
[Der Kranich] von Velimir Chlebnikov aus dem Jahr 1909, aber auch an die Prosa von Andrej Belyj aus dem Roman "Peterburg" (1912/13) und aus "Kotik Letaev" (1917).

Belyj und Chlebnikov sind wahrscheinlich die beiden vorrevolutionären Dichter, die am stärksten die frühe Sowjetliteratur beeinfluBt haben, und deren eingehendes Studium eigentlich am lohnendsten ist, vorausgesetzt, daß man Blok und Majakovskij nicht vergiBt.

Die Gliederung in Erzählsegmente ist in der Prosa Andrej Belyjs deutlich vorgeformt und wird dort als Mittel der Komposition zuerst konsequent angewand. Bei Zamjatin sind es die drei Petersburger Erzählungen "Drakon" [Der Drache], "Peščera" [Die Höhle] und "Mamaj" (nur die letztere ist nicht 1918 sondern 1920 entstanden), die am stärksten an Belyj erinnern, gleichzeitig aber durch ihr Sujet - Petersburg in der Zeit des sog. Kriegskommunismus - eine völlig andere gesellschaftliche Funktion erfüllen. Man muß diese Erzählungen im Zusammenhang mit dem 1919 entstandenen leidenschaftlichen Appell Zamjatins sehen, der den Titel "Morgen" (Zavtra) trägt. Zamjatin erinnert hier an den eigentlichen Zweck der Revolution, den Schutz und die Bewahrung des Menschen, die Befreiung des Menschen im Namen des Menschen:

"Война инпериалистическая и война гратданская обратили человека в материал для войны, в нумер, цифру. Человек забыт - ради субботы; мы хотим напомнить другое: суббота для человека... 
Словом русская интеллигенция, русская литература - десятилетия подряд боролась за великое человеческое завтра. И теперь время вновь поднять это оружие. Умирает человек. Гордый hото erectus становится на четвереньки, обрастает клыками и шерстью, в человеке - побеждает зверь."

[Der imperialistische Krieg und der Bürgerkrieg haben den Menschen in Material für den Krieg verwandelt, in eine Nummer, in eine Ziffer. Der Mensch ist vergessen, dem Sabbat zuliebe; wir wollen an etwas anderes erinnern: den Sabbat für den Menscher... Mit dem Wort hat die russische Intelligenz, die russische Literatur jahrzehntelang für das große menschliche Morgen gekämpft. Und jetzt ist es wieder Zeit, diese Waffe zu erheben. Der Mensch stirbt. Der stolze homo erectus kriecht auf allen Vieren, ihm wachsen Hauer und Fell, im Menschen siegt das Tier.]

"Die Höhle" ist vielleicht Zamjatins bekannteste Novelle, und hier ist im Titel schon die zentrale Metapher genannt: die Höhle des Urmenschen, die totale Regression, der soziale Nullpunkt. "Peščera" ist die Geschichte eines zur Intelligenz gehörigen Petersburger Ehepaares und spielt am 28. und 29. Oktober 1919 in einer eiskalten bürgerlichen Stadtwohnung, die bis 10 Uhr abends im Dunkeln liegt. Vorher gibt es kein Licht. Brennpunktartig erscheint die materielle und moralische Notlage in einer Verzweiflungstat zusammengezogen: Martin Martinyč stiehlt bei den Nachbarn ein paar Holzscheite, damit er am Namenstag seiner kranken Frau den Kanonenofen für ein paar Stunden heizen kann. Der Diebstahl kommt vorzeitig heraus und die beiden hilflosen und ungeschickten Leute geraten in eine Situation, aus der es keinen vernünftigen Ausweg mehr gibt. 
Der frühe Wintereinbruch hat Petersburg zu Eis gefrieren lassen, und die Semantik der ganzen Erzählung ist auf die Bedeutungsfelder "Eis" und "Höhle" hin orientiert. Das wirkliche Leben scheint erstarrt, und der Mensch erlebt seine eigene Regression in die Zeit des Höhlenmenschen. Die Geschichte hebt folgendermaßen an:

\begin{abstract}
"Ледники, мамонты, пустыни. Ночные, черные, чемто похохие на дома, скалы; в скалах пещеры. И неизвестно, кто трубит ночью на каменной тропинке мехду скал и, вынюхивая тропинку, раздувает белую снехную пыль; мохет быть, серохоботый мамонт; может быть ветер, а мохет быть - ветер и есть ледяной рев какого-то мамонтейшего мамонта. Одно ясно: зима. И надо покрепче стиснуть зубы, чтоб не стучали, и надо щепать дерево каменным топором; и надо всякую ночь переносить свой костер из пещеры в пещеру, все глубже. И надо всє больше навертывать на себя косматых звериных шкур."
\end{abstract}

[Gletscher, Magmute, Wüstenei. Nächtliche, schwarze, irgendworin Häusern ähnliche Felsen. In den Felsen gibt es Höhlen. Und man weiß nicht, wer nächstens auf dem steinernen Pfad zwischen den Felsen trompetet und den Pfad entlang schnaubend den weiBen Schneestaub emporbläst: vielleicht ein Mammut mit grauem Rüssel, vielleicht ist der Wind selbst das eisige Gebrüli irgendeines mammutartigen tbermammuts. Eines ist klar: es ist Winter. Und man muB die Zähne zusammenbeißen, damit sie nicht klappern und man muB das Holz mit einem Steinbeil spalten, und man muß jede Nacht sein Lagerfeuer aus einer Höhle in die andere tragen, immer tiefer, und man muB sich in immer mehr zottige Felle einwickeln.]

Es würde zu weit führen, die ganze Erzählung in ihrer Struktur aus diesem Segment zu entwickeln, aber da Zamjatin als Ingenieur mit fast mathematischer Folgerichtigkeit vorgeht, gibt es in dem Gewebe der Erzählung keine einzige brüchige Stelle.

Die metaphorische Reihe ist an sich sehr leicht zu entschlüsseln, die innerste Höhle ist das Schlafzimmer der beiden 
Menschen, Martin Martinyč und Maša, das letzte, zeitweise noch beheizbare Refugium. "Weiter konnte man nicht zurückweichen", heißt es im nächsten Erzählsegment, "hier mußte man die Belagerung durchstehen oder sterben."

Die einfache Alternative: durchhalten oder umkommen ist für die meisten Erzählungen aus der Bürgerkriegszeit typisch, und die Reduktion der komplizierten gesellschaftlichen Mechanismen auf die Gesetze des Höhlenmenschen hat hier bei Zamjatin ihr klassisches Modell gefunden.

Wir werden in dem nächsten Vortrag - über Pil'njak und Babel' - noch sehen, wie nach der ersten Phase der Sowjetliteratur, die ihren Höhepunkt 1923 erreicht, gesellschaftliche Konflikte zunehmend differenzierter aufgefaßt und entwickelt werden. Repräsentativ für eine betont primitivistische Perspektive der sozialen und politischen Bedeutung des Bürgerkrieges ist aber gerade der erste sowjetische Bürgerkriegsroman, die 1920 abgeschlossene panoramatische Erzählung unter dem Titel "Goly: gon" [Das nackte Jahr] von Boris Pil'njak. Bezeiclınenderweise erschien die erste Fassung dieses Buches 1922 in Berlin, in Ġem russischen Verlag Gržebin, der eine Reihe der besten jungen Autoren betreute.

Es bleibt uns noch übrig, kurz auf die Theatersituation einzugehen, die in diesen Jahren eine Reihe von ganz verschiedenen Aspekten bietet. Das liegt natürlich daran, daß es sich hier um eine Kunstform handelt, die von jeher mit dem Bühnenbild und mit der plastischen Darstellung verschwistert ist, die aber auch vom Regisseur und von den Schauspielern und inrer Bewegung zusätzlich abhängt bzw. auf sie zugeschnitten ist. Der sprachliche Text wird also durch andere Zeichensysteme überlagert und ist nicht allein für des Werk repräsentativ. 
Das vorrevolutionäre Theater der Symbolisten und Futuristen hatte ganz im Gegenteil zur realistischen Tradition Cechovs und Gorkijs das Drama dem Puppenspiel und dem Marionettentheater angenähert, daneben aber das Handlungsschema und die Konventionen des Mysterienspiels weitgehend in die Handlung integriert. Diesen Typus repräsentieren sowohl die Dramen Aleksandr Bloks, Sologubs und Leonid Andreevs als auch die Kurzdramen der Futuristen, in denen das Mysterium grundsätzlich parodiert erscheint: Chlebnikovs "Markiza Dézes" [Die Marquise Desaix], 1909, Chlebnikovs "Certik" [Das Teufelchen], 1909, mit dem Untertitel "Peterburgskaja šutka na roždenie Apollona" [Petersburger Scherz auf die Geburt des Apollon] und vom gleichen Autor "Ošibka smerti" [Der Fehler des Todes], 1915. Wichtig sind ferner Majakovskijs Monodrama "Vladimir Majakovskij", 1913, und Kručenychs "Pobeda nad solncem" [Sieg über die Sonne], ebenfalls 1913, das als Singspiel zu der Musik von Matjušin aufgeführt wurde und zu dem Kazimir Malevič die Dekoration entworfen hatte.

Dieses neue russische Theater, das Buffo-Szenen, Allegorien und groteske Handlungselemente miteinander verbindet, setzt mit Bloks "Balagančik" [Schaubude] ein 1906, und erfährt neue Variationen mit Bloks der ersten russischen Revolution von 1905 gewidmetem Drama "Korol' na ploščadi" [Der König auf dem Platz] 1906, mit Bloks anspruchsvollem aber nie aufgeführten Drama "Pesnja sud'by (1908) und weiter mit "Zizn'čeloveka" [Das Leben des Menschen] 1907, und "Car' Golod" [König Hunger] 1908, ebenfalls von Andreev. Als besondere Kompositionsform wären hier noch die "Stationen" zu erwähnen, deren Zusammenhang mit dem modernen Stationendrama of fenkundig ist. 
Auf dieser Grundlage baute Majakovskij 1918 mit seinem Buffo-Mysterium ("Misterija-buff") auf, das den Weg des Proletariats in das Gelobte Land zum Vorwurf hat, das aber anders gesehen das Erlösungsmysterium parodiert und zugleich damit Himmel und Hölle, die Sintflut und die Arche Noah.

Die Deutung seiner Gattungsbezeichnung hat Majakovskij im Prolog zur zweiten Fassung des Dramas für den III. KongreB der Komintern 1921 gegeben: "Proletarskoj misterii reka i bužuazii buff." [Der Fluß des proletarischen Mysteriums und der Buffo der Bourgeoisie.] Majakovskij erklärte aus diesem Anlaß:

\footnotetext{
"Действие 'Мистерии-буфо̛' - это движение толпы, столкновениє классов, борьба идей, - миниатура мира в стенах цирка."
}

[Die Handlung des 'Mysterium-buffo' ist die Bewegung der Masse, der Zusammenstoß der Klassen, der Kampf der Ideen - eine Miniatur der Welt im Zirkuszelt.] Uraufgeführt wurde das Drama in Meyerholds Inszenierung am ersten Jahrestag der Revolution, am 7. November 1918 in Petersburg im "Teatr muzykal'noj dramy" [Theater des musikalischen Dramas], allerdings erst nach der tberwindung verschiedener administrativer Hindernisse. Die offizielle Kritik hat Majakovskijs Stück nie sehr geschätzt, es wurde gleich wieder abgesetzt und selbst gegen Lunačarskij mußte Majakovskij sein Stück später einmal verteidigen. Als besonders anstoßerregend galt die Rolle des "Celovek prosto" [einfach ein Mensch], die Majakovskij selber spielte, eine Christus-Parodie, wenn man so will, denı der Mensch kommt wie Christus über das Wasser in die Arche geschritten und verkündet seine "neue Bergpredigt". Diese Szene wurde von den ersten Zuschauern als der Höhepunkt 
des Stückes empfunden und war auch so gemeint. Hier ist die Beziehung zu Majakovskijs futuristischen Verserzählungen in der Sprache ganz klar hergestellt.

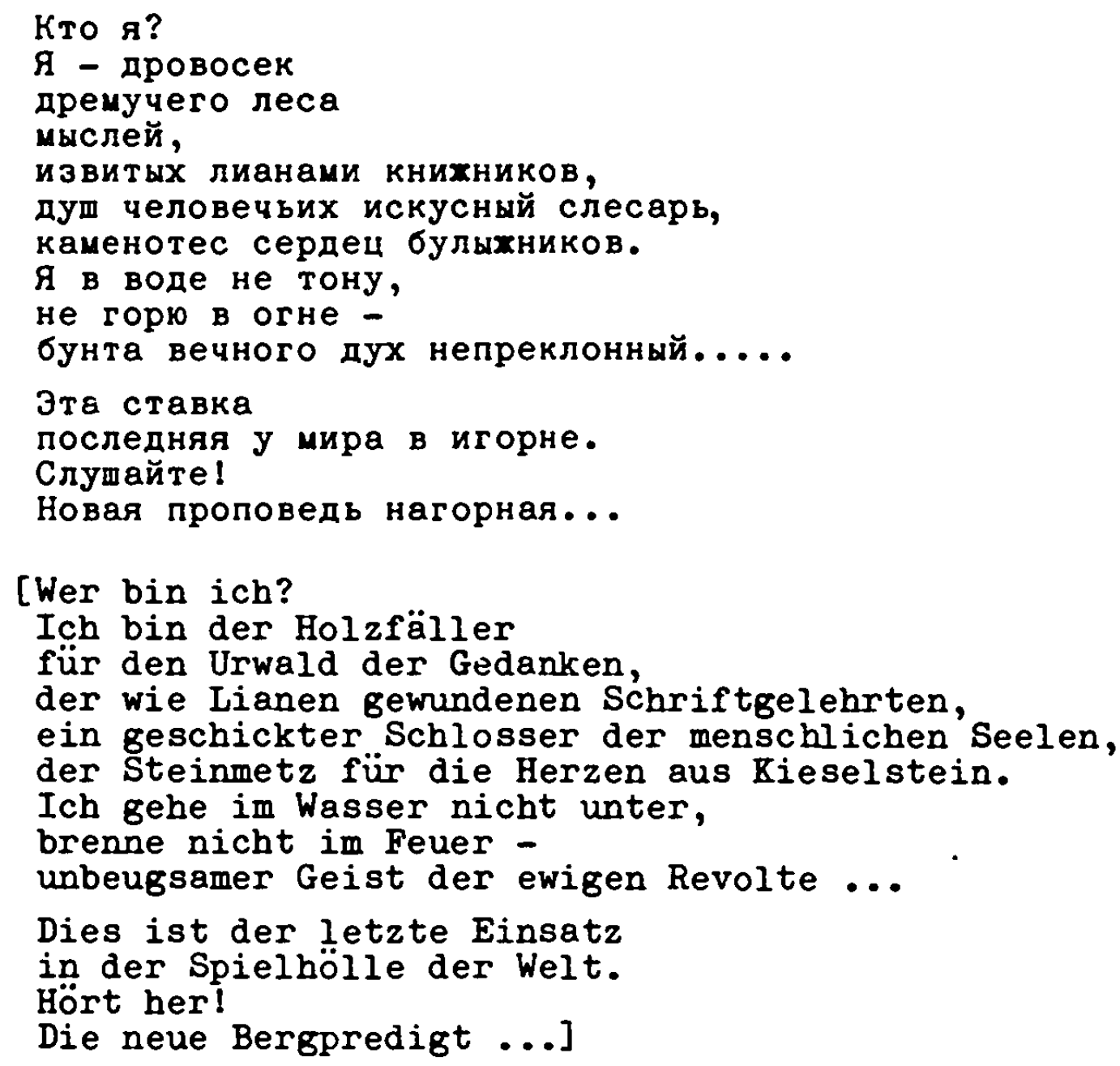

Für die zweite Fassung hat Majakovskij diese Rede etwas abgeschwächt, aber dadurch wurde das Stück nicht viel akzeptabler für die offizielle Kritik. Die wichtigsten Stationen und Schauplätze des Dramas sind das Deck der Arche, auf dem sich der historische Kampf zwischen den von der Sintflut überraschten Königen, Bürgern und Proletariern aller Länder abspielt, die Hölle, der Himmel und der Eingang zum Gelobten Land. Die politischen Anspielungen auf den Weltkrieg, die internationale Lage und die Revolution sind ganz deutlich und holzschnittartig zur Schau gestellt, während formal - sowohl sprachlich als 
auch im Hinblick auf die Personen und die Szene - das russische Volksdrama Pate gestanden hat. Besonders ist auf die Parallelen mit dem Volksstück "Car' Maksimilian" hingewiesen worden, einer satirischen Komödie des 18. Jhdts., die als eine Art Volksposse auBerordentlich beliebt war. Der Vers dieses Dramas ist der sogenannte "raješnyj stich" [Puppentheatervers], das Wort kommt von "Guckkısten, Panorıma". Der Vers selbst ist ein "frcier" Vers, der aber reimt und mindestens Assonanzen zur Bindung der Zeilen venutzt, eigentlich "Reimprosa". Mit diesem R̈̈ckgriff auf eine volkstümliche Gattung, die kurz vor dem ersten Weltkrieg zu einem gewissen Ansehen gelangt war, und zwar durch die Neuausgaben der Fhilologen, gelang Majakovskij ein wirklich zündendes revolutionäres Stück, dem ir der damaligen Zeit so leicht nichts an die Seite zu stellen war. Die futuristische Handschrift blieb allerdings auch unverkennbar, und die Tatsache, daß Tolstoj als "dekorativer" Heiliger im Himmel auch sein Teil an Spott abbekam, war wohl nicht nack dem Geschmack der Bewahrer des klassischen Erbes.

Außerordentlich amüsant und offenbar inspiriert von den russischen "lubočnye kartinki" [Holzschnittbilder] ist die burleske Szene in der Hölle. Hier konnte Mэjakovskij aber auch auf die Verserzählung vor Chlebnikov und Kručerych ("Igra v adu" [Spiel in der Hölle], 1912) zurückgreifen, die ihrerseits die Entstehung einer volkstümlichen Vorlage verdankt. Als Kuriosum darf man noch hinzufügen, daß sich Majakovskij auch für das moderne biblische Volksschauspiel interessierte, desser: Erreuerung in Rußland er unter Hinweis auf - ausgerechnet Oberammergau propagierte. (1913 ir dem Artikel "Teatr-kinematograf-futurizm [Theater-Kino-Futurismus]). Die Passionsspiele 1910 waren in Rußland tatsäcrlich serr stark beacktet und 
mehrfach kommentiert worden, die Ideen des Mysterienspieles und des Volksschauspieles lagen damals in der Luft.

Wichtig ist dabei, daß Majakovskij zwar das christliche Erlösungsmysterium parodierte, gleichzeitig aber - gewissermaßen in dialektischer Umpolung - das Mysterium des Proletariats und der gelobten Zukunft wiederherstellte. Damit stellte sich Majakovskij in eine literarische Reihe mit Esenin und dessen Epos "Inonija" [Das gelobte Land] 1918, und letztlich auch mit Bloks "Dvenadcat" . Natürlich muß man angesichts der Parallele mit Christus auch an Majakovskijs eigene Verserzählungen denken, vor allem "Celovek" [Der Mensch] 1917, der in Stationen eingeteilt ist: "Roždestvo Majakovskogo" [Majakovskijs Geburt], "Zizn' Majakovskogo" [Majakovskijs Leben], "Strasti Majakovskogo" [Majakovskijs Passion], "Voznesenie Majakovskogo" [Majakovskijs Himmelfahrt], "Majakovskij v nebe" [Majakovskij im Himmel], "Vozvraščenie Majakovskogo" [Majakovskijs Heimkehr], "Majakovskij vekam" [Majakovskij an alle Zeiten].

Zwischen 1918 und 1923 erlebt das russische Theater verschiedene Versuche einer Regeneration. Ohne die Einzelheiten hier zu berühren, möchte ich noch eine Linie nennen, auf der sich eine auch ästhetisch ganz neue Entwicklung vollzieht. Diese Linie wäre die sog. "Theatralisierung des Lebens", die von den Proletkult-Organisationen favorisiert und propagiert wurde, besonders von dem Theoretiker Keržencev. Zu diesem Programm gehörten dramatische Improvisationen ebenso wie Aufführungen unter freiem Himmel, Massenschauspiele und Massenbewegungen. In dem Artikel "Drama i massovye predstavlenija" [Drama und Massenschauspiele] schreibt Sklovskij 1920 (abgedruckt in "Chod konja", 1923): 
"И играет, играет Россия, происходит какой-то стихийный процесс превращения живых тканей в театральные. А тут Евреинов предлагает: 'Кахдая минута нашей хизни - театр.' Зачем это нам, когда у нас есть театр кахдую минуту!"

[Und Rußland spielt und spielt, es geht ein elementarer ProzeB der Verwandlung lebendiger Gewebe in Theatergewebe vor sich. Und da schlägt Evreinov noch vor: 'Jede Minute unseres Lebens ist Theater.' Was sollen wir damit, wenn wir schon Theater jede Minute haben!]

In einer anderen Bemerkung klagt Sklovskij:

"Этот истерический актеризм, охватываюий всю Советскую Россию, подобен жировому перерохдению тканей. И всему виной легко прехде добытое искусство - соблазн дешевого искусства."

[Dieser hysterische Akteurismus, der das ganze SowjetRußland erfaßt, gleicht einer fettigen Entartung der Gewebe. Und an all dem ist schuld, daß man es sich mit der Kunst zuvor so leicht gemacht hat, die Verführung der billigen Kunst.]

Sklovskij hielt das Theater ohne Rampe für ein künstlerisches Mißverständnis und er unterstrich in dem Beitrag: "O psichologičeskoj rampe" [tber die psychologische Rampe] die Notwendigkeit einer Auseinandersetzung des Theaters mit dem Zuschauer. Gerade das Spiel mit der Rampe, die direkte Zwiesprache des Dramenautors mit dem Zuschauer hält er für ein Element des Theaters, und noch wo die Rampe überspielt wird, ist sie als Aufbauelement des Dramas notwendig vorhanden. 
"Уничтохить психологическую рампу, это то хе,
что уничтохить, ну, например, аллитерации в
стихотворении."

[Die psychologische Rampe vernichten, das ist dasselbe wie, nun, zum Beispiel die Alliteration im Gedicht abschaffen.]

Uber das Massenschauspiel schreibt Sklovskij etwas ironisch:

\footnotetext{
"Народное массовое празднество, смотр сил, радость толпы есть утверхдение сегодняшнего дня и его апофеоз. Оно законно, когда на него никто не смотрит из окна или из особой триблны, иначе оно вырождается в парад, в крепостной балет и в оркестр роговой музыки. И уже поэтому оно не маскарад, и не театр."
}

[Das Massenvolksfest, die Kraftschau, die Freude der Menge ist die Bestätigung des heutigen Tages und ihre Apotheose. Es ist berechtigt, wenn ihm niemand aus dem Fenster zuschaut odervon einer besonderen Tribüne, sonst entartet es zu einer Parade, zu einem Leibeigenenballett, zu einem Hornmusikorchester. Und schon deswegen ist es keine Maskerade und kein Theater.]

Massenaufführungen unter freiem Himmel gab es in Petersburg aber gerade im Winter $1919 / 20$ und im ganzen Jahr 1920 sehr viele, und die Stationen des revolutionären Kampfes wurden immer wieder dargestellt, in lebenden historischen Bildern. Frei nach Majakovskij wurde am 1. Mai 1920 vor der ehemaligen Petersburger Börse von 4000 Rotarmisten ein "Mysterium" aufgeführt, für das die Maler Annenkov und Dobužinskij die Freilichtdekorationen geschaffen hatten. Die Bilderfolge war:

1. Akt, 1. Bild: "Die Arbeit". 2. Bild: "Die Herrschaft der Unterdrücker". 3. Bild: "Unruhen unter den Sklaven". 2. Akt, 1. Bild: Kampf der Sklaven mit ihren Unterdrückern" -2. Bild: 
"Sieg der Sklaven". 3. Akt: "Das Reich des Friedens, der Freiheit und der freudigen Arbeit".

Eine der bekanntesten und auch durch erhaltene Photographien dokumentierten Freilichtaufführungen war: "Die Einnahme des Winterpalais", aufgeführt am 7. November 1920, zum Jahrestag der Oktoberrevolution. Auf dem SchloBplatz traten unter Leitung von Evreinov 10000 Darsteller auf. Als Statisten dienten der Kreuzer "Aurora" auf dr Neva, Flugzeuge, Fabriksirenen und Kirchenglocken. Die gesamte Aufführung wurde auf kollektive Weise geplant. Diese Linie der Theaterarbeit wurde durch die Neue Okonomische Politik 1921 mehr oder weniger abgeschnitten, und für die späteren Jahre waren diese Experimente schon wieder zu "links". Sicher hat Sklovskij recht, daß diese Spiele keine Konkurrenz für das literarische Drama sein konnten, aber in einer Zeit der Erneuerung der ästhetischen Normen - auch im Hinblick auf die Entwicklung des Films hatten diese Aufführungen ihre besondere Funktion und sie sind in die Geschichte der frühen Sowjetkunst - schon ein wenig außerhalb des Rahmens der Literatur - eingegangen.

L iteraturangaben

A n n e n k o v, Jurij: Dnevnik moich vstreč. Cikl tragedij. I. New York 1966.

I $v$ a $n \circ v-R$ a $z$ u m $i k$ : Ispytanie ognem. In: Skify. Sbornik 1. St. Peterburg 1917.

I $v$ a $n \circ v-R$ a $z$ u $n i k$ : Ispytanie $v$ groze $i$ bure. In: Aleksandr Blok. Andrej Belyj. Peterburg 1919.

I v a o v - R a z u m n i k: A.I. Gercen 1870-1920. Skif sorokovych godov. Petrograd 1920.

J a u s s, Hans Robert: Literaturgeschichte als Provokation der Literaturwissenschaft. (Konstanzer Universitätsreden.3.) Konstanz 21969.

M a ja k o v s k i j, Vladimir: Teatr i kino.1. Moskva 1954. M a $j$ a $k$ ov s $k i j$, , vladimir: Etu knigu dolžen procest každyj ("Ržanoe slovo"). In: V. Majakovskij: Polnoe sobranie sočinenij $v$ trinadcati tomach. T. 12, Moskva 1959. 
M a ja k $\circ$ v s k i j, Vladimir: Teatr-kinematograf-futurizm. In: Op. cit. T. 1, Moskva 1955.

Proletarische Kulturrevolution in SowjetruBland (1917-1921). Dokumente des "Proletkult" herausgegeben von Richard Lorenz. Sonderreihe dtv 74. München 1969.

R i p e 1 l i n o, Angelo Maria: Majakovskij und das russische Theater der Avantgarde. Köln 1964.

s k 1 o v s k i j, Viktor: Chod konja. Sbornik statej. MoskvaBerlin 1923. (Gelikon)

S k 1 ○ v s ki j, Viktor: Petersburg während der Blockade. In: Die Serapionsbrüder von Petrograd. Aus dem Russischen übersetzt von Gisela Drohla. Frankfurt/M. 1963.

Z a m $j$ a $t i n$, Evgenij: Ostrovitjane. Povesti i rasskazy. Berlin-Peterburg-Moskva 1923 (Gržebin).

Z a m j a $t i \mathrm{n}$, Evgenij: Lica. New York 1955. 


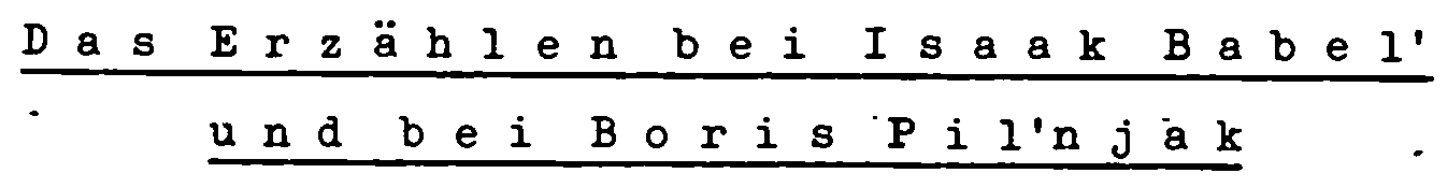

In dieser vergleichenden Gegenüberstellung möchte ich einige Eigentümlichkeiten zweier Dichter besprechen, die in besonders hohem Maße repräsentativ für die frühe Sowjetliteratur geworden sind, die jedoch am Ende beide einem System zum Opfer fielen, das sie in den entscheidenden Zügen durchschauten, dem sie aber nicht mehr entrinnen konnten.

Isaak Babel' ist seit 1954 "rehabilitiert", wie die heutige positive Einstufung für die Opfer lautet, und Il'ja Erenburg konnte 1957 eine erste Auswahl aus seinem Werk einleiten, nachdem Babel's Name lange Zeit überhaupt nicht mehr genannt worden war. Als das Sterbejahr gilt das Jahr 1941, die näheren Umstände des Todes, der auf die Verhaftung im Jahr 1939 folgte, sind für uns nicht greifbar. Boris Pil'njak, der im gleichen Jahr wie Babel' (1894) geboren wurde, verschwand schon 1937, sein Tod wurde aber erst 1963 offiziell bestätigt, nachdem auch Pil'njak im staatsbürgerlichen Sinn "rehabilitiert" worden war. Als Schriftsteller ist Pil'njak anscheinend auch heute noch unerwünscht. Neuauflagen seiner Werke sind nicht zu sehen.

Von beiden Erzählern kann gesagt werden, daB sie von jener übernationalen Strömung getragen wurden, die unter dem Namen "Expressionismus" zusammengefaßt wird, beide haben aus der "Sprachmischung" innerhalb der neuen Erzählsprache Nutzen gezo$\dot{\mathbf{B}} \mathrm{en}$, aus der Miśchung von verschiedenen Sprachschichten, deren

(Vortrag erstmalig gehalten am 22.3.1971 an der Universität Wien) 
Pole durch die bäuerliche Sprache und die metaphorisch-metonymische Ausdruckssprache der Lyrik gekennzeichnet sind. Beiden sind die Sitten und die vitalen Charaktere der russischen Provinz genau vertraut, beide erfassen die historischen Umwälzungen hauptsächlich als Milieuphänomene, bei beiden kommt es im Erzählvorgang zu scharfen Wechseln und Abbrüchen in Tonart, Sujetentwicklung und Erzähllogik.

Dennoch gibt es auch wesentliche Unterschiede, die in der Milieubehandlung, in der Raum-Zeit-Struktur und in der zentralen Perspektive $z u$ beobachten sind. Einer der grundlegenden Unterschiede zwischen beiden Erzählern scheint mir darin zu bestehen, daß Babel' als Autor den Figuren seiner erzählten Welt moralisch und physisch ganz nahe steht, während Pil'njak zwar eine Art Autorenperspektive entwickelt, in der er historisch Bilanz zu ziehen sucht, dabei aber die Figuren aus jeder engeren Bindung an das Autorengewissen entläßt. Pil'njaks Gestalten wirken fremder und abstrakter als Babel's "Helder" (die positiven wie die negativen), und wenn es auch, im Anschluß an die Tradition Gogol's und Andrej Belyjs bei Pil'njak echte Sprachkorik gibt, so ist Babel's menschlicher Humor, der sich aus den Interaktionen von Figuren und Milieu ergibt, viel stärker moralisch fundiert.

Betrachter. wir zunächst Babel' und dabei besonders das Verhältnis, das sich zwischen Autor und Personen aufzeigen läßt. Aus den erhaltenen Teilen des Gesamtwerkes lassen sich bei Babel' bekanntlich mehrere Zyklen herausschälen, darunter die Erzählungen aus Odessa und das Buch "Konarmija", die Geschichten aus der Reiterarmee des Generals Budennyj im russisch-polnischen Krieg. 
Früher war man der Ansicht, und Babel' hat diese Legende eigentlich selbst genährt, daB der Zyklus aus Odessa erst nach den Erzählungen aus "Konarmija" langsam herangereift sei. In Wirklichkeit waren die "Odesskie rasskazy" schon teilweise fertig, als Babel' mit der "Konarmija" begann. Später kam noch ein Frankreich-Zyklus hinzu (in den dreiBiger Jahren) und weiter einige selbständige Erzählungen, Romanfragmente und Dramen. Ein autobiographischer Zyklus wäre ebenfalls leicht herzustellen, aber Babel' hat die autobiographischen Geschichten niemals direkt zusammengefaBt, sondern in freier Folge einzeln veröffentlicht. Einige nur fragmentarisch erhaltene oder ganz verlorene Zyklen werden von F.M. Mierau in seinem interessanten Nachwort zu dem 1969 erschienenen Band mit Babel'-tbersetzungen ("Ein Abend bei der Kaiserin") erwähnt.

Babel' stammte aus Odessa, er war im Süden, an der Sonne des Schwarzen Meeres aufgewachsen. Davon handelt z.B. die autobiographische Erzählung "Probuždenie" [Erwachen], die 1931 veröffentlicht wurde. Diese Erzählung scheint mir wichtig, weil sie die Persönlichkeit des Autors als des Erzählers rückwärts blickend problematisiert. Diese Erzählung hat das Verhältnis des Erzählers zu seinen "Helden" zum Gegenstand und beschreibt eine Gemütslage, die etwa auch für den Erzähler in "Konarmija" gilt.

Der Erzähler schildert sich selbst hier als einen scheuen und phantasiebegabten Jungen, von den ehrgeizigen Eltern zum Geigenüben gezwungen, damit aus dem Kleinen ein Wunderkind werde wie aus anderen Judenkindern in Odessa:

\footnotetext{
"Хоть я и вышел из возраста вундеркиндов - мне тел четырнадцатый год, но по росту и хилости меня мохно было сбыть га возьмилетнего. На зто была вся надехда."
} 
[Obwohl ich dem Alter der Wunderkinder schon entwachsen war, ich war schon dreizehn, so konnte ich doch nach der Größe und nach meiner scbwächlichen Konstitution leicht für einen Achtjährigen gelten. Es war die einzige Hof fnung, die es gab.]

Der von der Natur so benachteiligte Junge träumt aber vielmehr davon, mit den braungebrannten Altersgenossen hinter der Hafenmole im Meer zu schwimmen und $z u$ tauchen. Leider ist er Nichtschwimmer, und erst ein menschenfreundlicher Schwimmfreund und Geschichtenerzähler aus dem Verlag der "Odesskie novosti" [Odessaer Neuigkeiten] bringt einer ganzen Schar von Nichtschwimmern, darunter auch dem Autor der Erzählung, die Fertigkeit des Schwimmens bei. Dieser Athlet aus der Novelle "Probuždenie", wohl einem der wichtigsten Glieder des unvollendeten autobiographischen Zyklus, ist der Prototyp der physisch starken und robusten Helden Babel's:

\footnotetext{
"С медными своими плечами, с головой состарившегося гладиатора, с бронзовыми, чуть кривыми ногами, - он лежал среди нас за волнорезом, как властелин зтих арбузных, керосиновых вод. Я полюбил этого человека так, как только может полюбить атлета мальчик, хворающй истерией и головными болями. Я не отходил от него и пытался услухивать."
}

[Mit seinen kupferbraunen Schultern, mit dem Kopf eines gealterten Gladiators, mit den bronzefarbenen, leicht krummen Beinen lag er. zwischen uns hinter dem Wellenbrecher, als Herr über diese von Wassermelonenschalen und Petroleum verschmutzte Wasserfläche. Ich verliebte mich so in diesen Menschen, wie sich in einen Athleten nur ein Knabe verlieben kann, der an Hysterie und ständigen Kopfschmerzen leidet. Ich wich nicht von seiner seite und versuchte ihm hie und da einen Gefallen zu tun.]

Es geht hierbei nicht um einen psychologischen Erklärungsversuch der Rolle Babel's als des Autors bestimmter Werke (wie z.B. "Konarmija"), auch nicht um den Gegensatz zwischen körperlicher Schwäche und physischer Gesundheit, welch letztere als faszinierende Vorgabe gedeutet wird. 
Rein biographisch betrachtet kann das alles ja auch viel weniger relevant gewesen sein. Es geht allein um die Stilisierung eines bestimmten Verhältnisses zwischen Autor und Held, um die Intimität und das moralische Engagement, das in dieser Stilisierung des "unheroischen" Autors zum Ausdruck kommt.

Auch einer von Babel's ersten Feuilletons, die unter dem Titel "Moi listki" [Meine Zettel] 1916/17 in einer Wochenschrift gedruckt wurden, beschäftigt sich mit Odessa, genauer gesagt, mit dem Unterschied zwischen Odessa und Petersburg. In der witzigen, an Gogol' erinnernden Erörterung wird ebenfalls die Vitalität der südlichen Landstriche hervorgehoben, jene unverwüstliche Vitalität, die den "Stoff" der Erzählungen Babel's ausmacht:

"Der Odessaer ist das gerade Gegenteil des Petrograders. Es ist eine Binsenweisheit, daB die Odessaer sich in Petrograd gut einrichten. Sie verdienen Geld. Da sie brünett sind, gewinnen sie die Liebe fülliger blonder Damen. Der Odessaer hat in Petrograd die Neigung, sich am Steininsel-Prospekt anzusiedeln. Man wird sagen, dies rieche nach einem Witz. Dem ist nicht so. Die Dinge liegen tiefer. Diese brünetten Menschen bringen einfach ein wenig Sonne und Leichtigkeit mit."

(Zitiert nach Isaak Babel, Ein Abend bei der Kaiserin. Erzählungen, Dramen, Selbstzeugnisse. Berlin 1969.)

Von diesen Betrachtungen wendet sich Babel' aber dann der tberlegung $z u$, ob nicht die russische Literatur durch den russischen Süden eine neue Orientierung finden könne, ob nicht die Zeiten der Petersburger Literatur, die Zeiten Turgenevs und Dostoevskijs, Zeiten der Nacht und des Nebels ohne Sonne, abgelöst werden müßten durch einen Dichter wie Maupassant, einen Dichter, den Babel' damals für sich neu entdeckt 
hatte. Gogol' - so stellt Babel' hier klar - kam zwar auch aus der Ukraine, aber er wurde schlieBlich ein echter Petersburger: "Petersburg hatte Poltava besiegt." Ein russischer Maupassant müßte also aus Odessa kommen: "Der literarische Messias, auf den man schon so lange und so fruchtlos wartet, wird von dort kommen - aus den sonnigen, meerumspülten Steppen."

Mit sicherem Instinkt für die literarische Entwicklung, für die Entwicklung des literarischen Geschmacks entdeckt Babel' hier die Rolle Odessas in der frühen Sowjetliteratur (E. Bagrickij, V. Kataev, Il'f und Petrov) schon vor der Revolution. Daß aber der sonst von ihm geschätzte Gor'kij dieser "Messias" sein könne, wird hier von Babel' bezweifelt:

"Gorki ist der Vorläufer und der Stärkste in unserer Zeit. Aber er ist kein Sänger der Sonne, sondern ein Herold der Wahrheit: Wenn etwas zu besingen lohnt, so wisset - es ist die Sonne. In Gorkis Liebe zur Sonne ist etwas, was vom Kopf herkommt ..." Es zeugt für die bewriBte Kontinuität in Babel's Schaffen, daß der Kern dieser Skizze, der Vergleich der südlichen Lebensfreude und des Sonnenlichtes mit Petersburg das dynamische Motiv für die erst 1932 veröffentlichte Erzählung "Guy de Maupassant" abgeben sollte. Babel' erinnert sich hier an seine frühe Petersburger Zeit im Kriegsjahr 1916, und der erste Satz lautet: "Zimoj šestnadcatogo goda ja očutilsja v Peterburge s fal'šivym pasportom i bez groša deneg." [Im Winter des Jahres 16 fand ich mich in Petersburg wieder, mit einem falschen $P a ß$ und ohne einen Pfennig Geld.] toer den autobiographischen Hintergrund kann es hier überhaupt keine Zweifel geben, aber der Ich-Erzähler macht aus sich hier 
nicht den empfindsamen Helden eines wie immer gestalteten Bildungs- oder Reifungsprozesses, sondern er fabuliert vom Fleck weg wie der Held einer Schelmennovelle, und so wird die Begegnung mit Raisa Michajlovna Benderskaja, der reichen jüdischen Dame, die einen Helfer für ihre Maupassant-tbersetzungen sucht, eher wie ein echtes Abenteuer erzählt als wie eine Belehrung über Klassengegensätze.

Das Verhältnis des Erzählers zu seiner "Heldin" ist unbefangen, ja scheinbar naiv und bewundernd:

\begin{abstract}
"В гостиную, неся большую груд, вошла червоноволосая хенщина с розовыми глазами. Не нужно было много времени, чтобы узнать в Бендерской упоительную эту породу евреек, пришедших к нам из Киева и Полтавы, из степных, сытых городов, обсахенных каштанами и акациями. Деньги оборотистых своих мужей зти женщины переливают в розовый хирок на хивоте, на затылке, на круглых плечах. Сонливая, нехная их усмешка сводит с ума гарнизонных офицеров."
\end{abstract}

[Den Salon betrat, die große Brust tragend, eine rothaarige Frau mit rosigen Augen. Man brauchte nicht lange, um in der Benderskaja jene hinreißende Sorte von Jüdinnen zu erkennen, die aus Kiev und Poltava zu uns gekommen sind, aus den steppennahen, satten Städten, deren Baumbestand aus $\mathrm{Ka}-$ stanien und Akazien besteht. Die Gelder ihrer findigen Ehemänner gießen sie um in rosa Fett auf dem Bauch, im Nacken, .. auf den runden Schultern. Ihr schläfriges und zärtliches Lächeln bringt die Garnisonoffiziere um den Verstand.]

Es fällt nicht schwer, im Erzählduktus die präzise Wertung des Erzählers zu bemerken, ein Geflecht aus positiven und negativen physischen Reaktionen, aus positiven und negativen moralischen Einschätzungen. Das äuBerst humorvoll geschilderte Abenteuer mit Raisa, das sich um die gemeinsame tbersetzung der Erzählung "L'aveu" von Maupassant rankt, jener Erzählung, die schon in dem Feuilleton "Odessa" eine Rolle spielt, bleibt ganz ohne jede Verkrampfung, weil Babel' wie auch in anderen 
Fällen das Milieu - vorzugsweise das jüdische Milieu - nicht nur einsetzt, um einer historischen Epoche Relief zu verleihen, sondern auch um den Figuren Halt zu geben. Dieses Milieu kann das Milieu eines ärmlichen jüdischen Altersheims sein, wie in "Konec bogadel'ni" [Ende des Armenhauses], gedruckt 1932, vom Autor datiert 1920-29, oder wie in "Guy de Maupassant" das Prunkhaus an der Ecke des Nevskij Prospekt und der Mojka, wo wiederum charakteristische Details die humoristische Wirkung unterstützen:

"По лестнице пролегал красный ковер. На площадках, поднявшись на дыбы, стояли плюшевые медведи. В их разверстых пастях горели хрустальные колпаки."

[Uber die Treppe breitete sich ein roter Teppich. Auf den Abṣätzen standen aufgereckt Bären aus Plüsch. In ihren gähnenden Rachen brannten kristallene Lampenkuppeln.]

Die repräsentative Einzelheit, das Erzähldetail, erfüllt bei Babel' oft eine ganze Reihe von Funktionen. Die ästhetische Zeichenfunktion dieser scheinbaren "Belanglosigkeiten" weist auf Bezugsfelder, die das Sujet transzendieren und weit in die geschichtlichen Konflikte hineinreichen. Babel's Lakonismus erlaubte diese Art der "gegenständlichen" Oppositionen, die ja in der berühmten Stelle aus der "Konarmija" einen anschaulichen Ausdruck finden, wo in "Syn Rabbi" [Der Sohn des Rabbi], 1924, die Habseligkeiten des tödlich verwundeten Rotarmisten aufgezählt werden:

"Портреты Ленина и Маймонида лежали рядом. Узловатое железо ленинского черепа и тусклый шелк портретов Маймонида. Прядь хенских волос была залотена в книхку постановлений шестого съезда партии, и на полях коммунистических листовок теснились кривые строки древнееврейских стихов. Печальным и скупым дохдем падали они на меня - страницы 'Песни песней' и револьверные патроны." 
[Porträts von Lenin und Maimonides lagen nebeneinan-der. Das knotige Eisen von Lenins Schädel und die matte Seide der Bilder von Maimonides. Eine Strähne von Frauenhaar steckte in der Ausgabe der Beschlüsse? des sechsten Parteitages, und auf den Rändern kommu-nistischer Flugblätter drängten sich die krummen Zeilen hebräischer Verse. Als trauriger und geiziger Regen fielen sie mir entgegen - die Seiten des Hohenliedes und Revolverpatronen.]

Es ist dies das "genau abgestimmte, dynamische System von Oppositionen" (Fritz Mierau), in dem Babel' die Zeitproblematik modellartig einfängt. Nicht verschwiegen werden darf' jedoch, daß in diesem System die physisch-körperliche Sphäre in ihrer von prüden Lesern leicht als anstößig empfundenen Deutlichkeit und Nacktheit ihren wichtigen Platz hat. Auf der gleichen Seite der Erzählung "Syn Rabbi", wo davon berichtet wird, wie der schwer verwundete Sohn des Rabbi von den Insassen eines Militärzuges in den Waggon gehoben wird, zeigt der Erzähler den geschundenen Körper des jungen Soldaten in seiner hilflosen Entblößung, aber im 'System" der natürlichen Gegensätze :

\footnotetext{
"Голые колени, неумелые, как у старухи, стукались о рхавое железо ступенек; две толстогрудые машинистки: в матросках волочили по полу длинное застенчивое тело умирающего."
}

[Die nackten Knie, hilflos wie bei einer alten Frau, stießen sich an dem rostigen Eisen der Trittbretter; zwei vollbusige Stenotypistinnen in Matrosenblusen zogen den langen schamhaften Körper des Sterbenden über den Boden.]

Babel's Erzählung bezieht einen Teil ihrer Wirkung aus der Intimität zwischen Autor und Held, einer physischen wie moralischen Intimität, die sich dem Leser mitteilt. In der Erzählung "Syn Rabbi" bezieht sich der Erzähler des Zyklus zunächst auf eine schon früher erzählte Geschichte mit dem Titel "Rabbi", in der Il'ja, der Sohn des Rabbi, nur eine Nebenfigur ist. Zur Herstellung der Beziehung bedient sich der 
Erziähler in "Syn Rabbi" der (fiktiven) persönlichen Anrede an seinen Kameraden Vasilij, der jenes erste Erlebnis mit ihm geteilt hatte:

"...Помнишь ли ты Житомир, Василий?...

...Помнишь ли эту ночь, Василий?..."

[... Erinnerst du dich an Zitomir, Vasilij? ...

... Erinnerst du dich an diese Nacht, Vasilij? ...]

Der Erzähler bleibt auf diese Weise, wenn er seine Rolle nicht ausdrücklich an eine seiner Figuren abtritt, wie in der "Skaz"-Erzählung "Sol"" [Salz] aus "Konarmija", meistens persömlicher Erzähler mit mehr oder weniger genau definierbaren Bimdungen an die geschilderten Figuren. Das gilt sogar, wenn auch in eingeschränktem Grad, von den Erzählungen des Odessa-zyklus. Der Erzähler ist hier, gewissermaßen, der "Unparteiische", der ganz am Rand stehende Chronist, der auf jene Geschichten spezialisiert ist, die sich um den "König" der Unterwelt, Benja Krik, ranken.

In gewissem Sinn glorifiziert Babel' hier sogar die jüdische Unterwelt der Schmuggler, Bankräuber, Erpresser und Brandstifter. Objektiv sind diese Banditen Asoziale, aber nicht in Babel's ästhetischem Verständnis. Babel' baut die Gegenwelt des jüdischen Familienlebens um sie herum auf, des jüdischen Rituals und des jüdischen Sinns für Komik. In den Odessa-Geschichten ist Benja Krik nicht nur der Gewaltverbrecher, der seinem zukünftigen Schwiegervater Sender Ejchbaum das Dach über dem Kopf anzündet, die jüdischen Großhändler terrorisiert, sondern eher ein echter Schelm wie "Herschele" Ostropoler, der Held der frühen (1918) Erzählung "Sabos-Nachmu" [Name eines jüdischen Feiertages], ein Freund der Armen, die er zur Hochzeitstafel einlädt, Feind der Reichen aus einer Art Berufsstolz. Benja stammt selbst aus einer anständigen Familie, sein Vater 
ist der Fuhrunternehmer Mendel' Krik, und die Hochzeit seiner Schwester läBt er nach jüdischer Sitte und nach jüdischem Brauch ausrichten mit einer riesigen Tafel im Freien. An jenem Abend - das wird in der Novelle "Korol'" [Der König], 1923, erzählt - schlägt Benja Krik der Polizei, die eine Razzia plant, ein Schnippchen und läBt das Polizeirevier in Flammen aufgehen. Im übrigen ist aber besonders das Detail wichtig, das Babel' liebevoll ausmalt und das sich zu einer Simultanstruktur (F. Mierau) in einem kontrastierenden Wechselspiel der beiden Milieufaktoren (jüdische Tradition und Banditentum) zusammenfügt. Schon bei den Vorbereitungen in der Küche spielen semantisch das Feuer und die ausströmende Hitze eine integrierende Rolle. Gleichzeitig ist aber auch die Spannung zwischen physischer Intimität und trockenem lakonischen Humor in der ganzen Erzählung von besonderer struktureller Bedeutung:

\footnotetext{
"Квартиры были превращены в кухни. Сквозь закопченные двери било тучное пламя, пьяное и пухлое пламя. В его дымных лучах пеклись старушечьи лица, бабьи тряские подбородки, замусоленные груди. Пот, розовый, как кровь, розовый, как пена бешеной собаки, обтекал эти груди разросшегося, сладко воняющего человечьего мяса. Три кухарки, не считая судомоек, готовили свадебный ужин, и над ними царила возьмидесятилетняя Рейзл, традиционная, как свиток торы, крохотная и горбатая."
}

[Die Wohnungen hatten sich in Küchen verwandelt. Durch die ruBigen Türen schlug die satte Flamme, eine trunkene und aufgedunsene Flamme. In ihrem rauchigen Schein brieten die Gesichter alter Frauen, wabbelige Kinnbacken junger Weiber, feuchtglänzende Brüste. SchweiB, rosig wie Blut, rosig wie der Geifer eines tollwütigen Hundes $f l o B$ über diese Berge von hervorquellendem, süB riechendem Menschenfleisch. Drei Köchinnen, nicht gerechnet die Geschirrspülerinnen, richteten das Hochzeitsmahl, und über ihnen herrschte die achtzigjährige Reisl, traditionell wie eine Thorarolle, winzig und bucklig.] 
Farben und überhaupt sinnliche Wahrnehmungen haben in Babel's Prosa die Funktion bestimmter Steuerungsmechanismen der ästhetischen Wirkung. Uppige oder häBliche Körper, auffällige Farben und kontrastreiche, überraschende, unter Umständen schockierende Metaphern sind der eigentliche Nährboden für die scharfe, sehr skeptische und "scheinbar" unbeteiligte Analyse menschlichen Verhaltens. Das einzige, was Babel' nicht kennt, ist explizit, deutlich ausgesprochenes Mitleid.

Die skeptische Ambivalenz, die für das Verhältnis des Erzählers zu seinen Helden oder Antihelden in der "Reiterarmee" gilt, und die 1924 die Entrüstung des Reitergenerals Budennyj auslöste, durchzieht auch die erst seit 1964 bekannte Erzählung "Froim Grač", die gewissermaßen den Epilog zu dem "Odessa-Zyklus" darstellt. Diese vermutlich Anfang der dreißiger Jahre entstandene Geschichte, die damals nicht gedruckt werden durfte, ist dem Ende der Unterwelt von Odessa gewidmet, die anfänglich versuchte, auch der Tscheka zu trotzen, nach und nach aber ausgerottet wurde. Die Banditen hatten zwar im Bürgerkrieg auch gegen die Weißen gekämpft, aber die neue Macht akzeptierte diese Komplicenschaft nicht und es begann nun ein gnadenloser Kampf zwischen der Tscheka und den Banditen, deren greises Oberhaupt Froim Grač den Namen für die Erzählung geliefert hat. Nach einem Banküberfall werden die ersten Banditen gefabt, aber an dem Spitzel, der sie der Polizei ausliefert, wird grausame Rache genommen.

Die Erzählung ist eines der späten, ganz lakonischen Werke von Babel', und in ihr steht die Sowjetmacht, die mit der Banditen-Romantik in Odessa aufräumt, schon im Zwielicht. Babel' baut die Erzählung auf dem Dialog auf, den er mit den Jahren immer besser beherrscht. Den Dialog oder die sprachli- 
che Stilisierung in der Ich-Erzählung nutzt Babel' in den späteren Erzählungen meisterhaft für die Darstellung der Milieukontraste aus, das hängt ganz bestimmt auch mit seinem Weg zum Drama ("Zakat" 1928 und "Marija" 1935) zusammen. Der Bandit Miša Jabločko lädt den vertrauensseligen Spitzel Aron Peskin zu einer kleinen Ausfahrt ein, von der er ihn am Abend nach Hause bringt: als Halbtoten, den er vor dem Haus an einen Gartentisch anlehnt. Mit der nichtsahnenden Frau des Erschlagenen, die gerade ihre vierzehnjährige Tochter in einer Bütte badet, führt er noch ein kurzes Gespräch voller ironischer Anspielungen, worauf er verschwindet. Gespenstische Ironie liegt nun der Schimpfkanonade der Frau Peskina zugrunde, die glaubt, daB ihr Mann sie bloß höhnisch angrinst:

\footnotetext{
"Авантюрист, - сказала ему мадам Пескина, - ты еше смеешься... У меня делается припадок от твоей дочери, она не хочет мыть голову... Пойди, имей беседу с твоей дочерью..."
}

[Hochstapler, - sagt Madame Peskin zu ihm, - du lachst auch noch. Ich kriege einen Anfall wegen deiner Tochter, sie will sich nicht die Haare waschen ... Komm, rede du mal ein Wort mit deiner Tochter ....]

Erst als gar keine Antwort kommt, merkt die Frau, was geschehen ist. Peskin ist zwar noch nicht tot, aber er stirbt bald darauf unter dem Messer des Chirurgen Silberberg. Das alles wird vom Erzähler äuBerst lakonisch vorgebracht, ebenso wie das, was in der gleichen Nacht darauf folgt: zwei Komplicen der Mörder werden aufgestöbert und nach einem Verhör, "das nicht lange dauerte", erschossen. Unter den ehemaligen Banditen wird aufgeräumt. Froim Grač selbst macht noch den Versuch, mit dem Vorsitzenden der Tscheka zu reden, er glaubt, als "König" der Unterwelt freies Geleit erwarten zu können, er ist selbst unbewaffnet gekommen: 
" - Я пустой, - сказал тогда Фроим, - в руках у меня ничего нет и в чоботах у меня ничего нет и за воротами на улице я никого не оставил... Отпусти моих ребят, хозяин, скахи твою цену."

[- Ich bin leer, - sagte Froim da. Ich habe nichts in den Händen, auch in den Stiefelschäften habe ich nichts, und am Tor auf der Straße habe ich ebenfalls niemanden aufgestellt. Laß meine Jungens frei, Chef, sag deinen Preis.]

Der frühere "Ehrenkodex", den auch die Unterwelt akzeptierte, gilt aber in der neuen Gesellschaft nicht mehr. Der 23-jährige Vorsitzende der Tscheka läßt Froim kurzerhand und auf der Stelle liquidieren.

Der Untersuchungsrichter Borovoj, für den Froim Grač ein "grandioser Bursche" ist, und der sich nicht vorstellen kann, daß die Geschichte Odessas ohne diese Burschen die gleiche gewesen wäre, ist der einzige, der um den Alten trauert. "Objektiv" ist der Gerechtigkeit genüge geschehen, aber die Worte, die er dem Vorsitzenden der Tscheka entgegenhält, sind bitter:

\footnotetext{
"Вы не одессит, вы не можете этого знать, тут целая история с этим стариком..."
}

[Sie sind nicht aus Odessa, Sie können das nicht wissen, das ist eine ganze Geschichte mit dem Alten ....]

Nur auf die Frage nach dem "Nutzen" eines solchen Menschen in der "zukünftigen Gesellschaft" kann der Untersuchungsrichter nicht viel sagen: die so gestellte Frage konnte auch Babel' nicht anders als negativ beantworten. Die moralischen Akzente, die der Erzähler setzt, kommen anderswo zum Tragen. Sie betreffen die Frage nach der Menschenwürde mehr als die nach der gesellschaftlichen Nützlichkeit. 
Wenn man sagen darf, daß bei Isaak Babel' das Milieu als ästhetisches und moralisches Gegengewicht zur historisch als notwendig erkannten Veränderung der Lebensbedingungen in Erscheinung tritt, so ist im Gegensatz dazu das Milieu bei Boris Pil'njak in viel stärkerem Maße Fessel und Bannkreis der Menschen. Das Milieu verdichtet sich zu einem mythenähnlichen Gewebe, in das die Personen fast hoffnungslos verstrickt bleiben. Bestimmte Gegenstände erlangen die Herrschaft über Menschen, und es ist sicherlich kein Zufall, daB Pil'njak beim Erzählen immer wieder auf Titel verfallen ist, in denen nicht Menschen sondern Sachen genannt sind. Das beginnt schon mit "Vešči" [Gegenstände], 1918, und findet über "Staryj syr" [Alter Käse], 1923, "Staryj dom" [Das alte Haus], 1924, über den Roman "Mašing i volki" [Maschinen und Wölfe], 1925, eine Fortsetzung bis zu der im Ausland gedruckten Erzählung "Krasnoe derevo" [Mahagoniholz], 1929.

Pil'njaks einzelne Erzählungen setzen vielfach mit der Beschreibung des Milieus oder mit der Aufzählung geographischhistorischer Daten ein, nicht aber mit der Charakterisierung der Personen, die vor allem in ihrer Abhängigkeit vom Milieu in Erscheinung treten. Die Entwicklung der Charaktere verläuft bei Pil'njak insofern aperspektivisch, als sich der Autor (bzw. der Erzähler) selten zu ihrem Anwalt macht.

Gelegentlich wird überhaupt nur eine Sicht der Personen "von innen" gegeben, z.B. in der Erzählung "Staryj syr", in der die eine der beiden weiblichen Hauptpersonen Marija durch ihren Brief nach London eingeführt wird, die andere ( 01 'ga Dmitrievna) aber durch ihr Tagebuch. Die Erzählung setzt sich so aus verschiedenen Segmenten zusammen, und das wird noch dadurch unterstrichen, daß die Handlung an verschiedenen Schau- 
plätzen spielt (in der Kirgisensteppe und in London) und daB der Erzähler hier tatsächlich die "Vogelperspektive" einnimmt. Am Beginn des 2. Kapitels, wo er selbst das Wort ergreift, liefert er eine Beschreibung des Bürgerkrieges aus der philosophischen Distanz:

"От Урала и степей шли бело-голубые, в английских шинелях, со старообрядческими крестами, бородатые. От Москвы и Питера, от городов и машин шли красные в рабочих куртках, бритые, со звездами и без молитв. За увалами ставились пушки, палили по речным просторам, по туманам, по городам. Полыхали непокорные села - красными петухами, степными вешками."

[Vom Ural bis zu den Steppen marschierten die WeißBlauen, in englischen Militärmänteln, mit den Kreuzen der Altglaubigen, mit Bärten. Von Moskau und Petersburg, von den Städten und Maschinen marschierten die Roten in Arbeitsjacken, rasiert, mit Sternen und ohne Gebete. Hinter Bodenwellen wurden Kanonen aufgestellt, die schossen gegen die Flußniederungen, gegen den Nebel, gegen Stâdte. Hell loderten die unbotmäßigen Dörfer als rote Hähne, als Signalstangen in der Steppe.]

Es darf hier nicht unbeachtet bleiben, in wie hohem Maße die ganze Passage stilistisch von Vorbildern bei Andrej Belyj ("Serebrjanyj golub"" [Die silberne Taube] und "Peterburg") abhängig ist. Wichtig erscheint mir aber auch, daB diese umfassende Autorenperspektive, die Pil'njak zur Regel erhoben hat, eine besondere strukturbildende Funktion erhält. Sie steht in schroffem Gegensatz zur milieugebundenen Erlebniswelt der Personen und bildet den deutenden und wertenden Gegenpol zur "blinden" Perspektive der Helden. Gerade die tberwindung geographischer Grenzen ist dabei typisch. Pil'njak fühlt sich als Erzähler nicht an ein räumliches und auch nicht an ein zeitliches Kontinuum gebunden, und insofern haben die erzählerischen tberleitungen des vorgeführten Typus die Funktion deutender und kommentierender Zusammenfassungen. 
Geographische Breite wird bei Pil'njak so zu einem Gegengewicht gegen die Enge des Milieus, und in Pil'njaks erstem Roman "Golyj god" [Das nackte Jahr], 1922, findet sich schon eine interessante Stelle über den Geographieunterricht, den der Händlerssohn Donat Ratčin genossen hat:

"В училище учитель Бланманжов заставлял Доната, как и всех учеников, путешествовать по карте: в Иерусалим, в Токио (морем и сушей), в Буэнос-Айрес, в Нью-Иорк, перечислять места, широты и долготы, описывать города, людей и природу, - городское училище было сплошной географией..."

[In der Schule zwang der Lehrer Blanmanžov Donat, so wie auch alle anderen Schüler, auf der Landkarte zu reisen: nach Jerusalem, nach Tokio (zu Wasser und zu Lande), nach Buenos Aịres, nach New York, alle Orte aufzuzählen, die Längen und Breiten, die Städte zu beschreiben, die Menschen und die Natur, - die städtische Schule war überhaupt nur Geographie ....]

Man muß in diesem Zusammenhang auch erwähnen, daß viele Werke Pil'njaks tatsächlich mit weiten Reisen verbunden sind (z.B. "Korni japonskogo solnca" [Die Wurzeln der japanischen Sonne], 1927), andererseits aber, daß neben "Sachtiteln" gerade die geographischer Titel eine besondere Rolle spielen: "Rasskazy o morjach i gorach" [Erzählungen über Meere und Berge], 1919; "Gorod vetrov" [Die Stadt der Winde], 1928; "Volga vpadaet $v$ Kaspijskoe more" [Die Wolga fließt ins Kaspische Meer], 1930.

Geographische, klimatische und historische Milieufaktoren verdichten sich bei Pil'njak wiederum zu ganzen Mythen, denen sich die Figuren seiner Erzählungen und Romane zu stellen haben. Da die "reale" Wirklichkeit auch in Pil'njaks Erzählstoffen als die dynamische und das heiBt meistens die revolutionäre Umgestaltung der gesellschaftlichen Beziehungen hereinbricht, kommt es im Grunde immer zum gleichen Antago- 
nismus zwischen Organisation, technischem Fortschritt und politischer Emanzipation auf der einen Seite, und dem "asiatischen" Mutterboden auf der anderen Seite. Boris Pil'njak vertritt mit seinen Mythen die geschichtsphilosophische Linie der sog. "Eurasier" und sucht die Geschichtsträchtigkeit des "tatarischen" und des "skythischen" Rußland zu erweisen.

Charakteristischerweise spielt gerade die Handlung des frühen Romans "Golyj god" in einer kleinen, altertümlichen Provinzstadt irgendwo im Innern RuBlands, "mehr als tausend Werst von überall" entfernt. Der Name Ordynin gorod (die Stadt ist so benannt wie die ortsansässige Adelsfamilie Ordynin) weist eindeutig auf die Goldene Horde (Orda), die tatarische Vergangenheit ist Bestandteil des Mythos. Dieser erste Roman kommt fast ohne eine kohärente Fabel aus, nicht aber ohne einen Mythos, nicht ohne Geschichte. In der ständigen Auseinandersetzung mit der Geschichte entfaltet sich das Zeitpanorama des "nackten" Hungerjahrs 1919. Jede Person sieht die Vorgänge mit ihren besonderen Augen, jede Person philosophiert für sich, der Erzähler schafft nur die rhapsodischen Ubergänge.

Die historische Veränderung RuBlands durch die Revolution wird bei Pil'njak durchaus nicht bagatellisiert, doch fällt dareben die Betonung der Kontinuität des Alten im Neuen auf. Ein typisches Pil'njak-Motiv ist die Heimkehr nach langer Abwesenheit oder etwa die Suche nach der eigenen Vergangenheit. In "Gorod vetrov" z.B. wird erzählt, wie ein als Kind von den Deutschen verschleppter Russe mit seinem deutschen $P a B$ nach Hause reist, um nach dem eigenen Vater zu suchen. Diese Suche führt ihn nach Baku, der Stadt der Erdölindustrie, aber auch der alten Stadt an der Schwelle Asiens, in der noch 
im 19. Jahrhundert indische Feueranbeter, d.h. Anhänger des Zoroaster lebten.

Pil'njak rechtfertigt hier die menschlichen sozialen Instinkte, die den Menschen zwingen, Städte und Fabriken zu bauen, Schiffe, Flugzeuge und Eisenbahnen. Aber im gleichen Boden, in den sich die Menschen mit ihren Bohrtürmen hineinfressen und den sie ausbeuten, leben auch die Erinnerungen und die Legenden. So kann sich der Erzähler in "Gorod vetrov" am Schluß das Wortspiel leisten, daB niemand von den beteiligten Personen sich an diesem Tag dessen bewußt wurde, daß die zwei Wörter "indusy" [Inder] und "industrija" [Industrie] fast gleich klingen. Die erzählte Geschichte ist eigentlich nur die "Sujetisierung" dieses Wortspiels, das einen tiefen Antagonismus zu überbrücken sucht.

Mit Wortspielen und echten "Kalauern" arbeitet Pil'njak (wohl auch wieder im Anschluß an Andrej Belyj) nicht selten. In ihnen zeichnen sich z.B. die Widersprüche $a b$, die in das alte gewachsene Milieu durch die technische Entwicklung hineingetragen werden. Einen solchen Kalauer benutzt Pil'njak in "Golyj god" am Beginn des vierten Kapitels, und zwar sowohl als Uberschrift des ganzen Kapitels als dann auch in dem anekdotenhaften Motto: "Komu - tatory, a komu - ljatory" [Für den einen 'Tatoren', und für wieder einen 'Latoren'.] Die als Motto dem Kapitel vorangestellte Anekdote klärt den Sinn erst auf. Vor einer Moskauer Handlung mit Elektrogeräten steht ein Mann und liest das (nicht ganz fehlerfreie) Schild: "Kommutatory, akkomul jatory" [Kommutatoren, Akkomulatoren]. Der Mann liest laut: 
" - Ком-му ... таторы, а... кко-му ляторы и говорит:

- Вишь, и тут обманывают простой народ."

[- Für den einen ... Tatoren, und für wieder einen Latoren ... und er sagt: - Siehst du, auch da wird das einfache Volk betrogen ! ...

In den Uberschriften der Unterteile des Kapitels kehren diese falsch abgetrennten Nonsense-Wörter dann sogar noch wieder: "Provincija, znaete li. Gorodskie tatory." [Provinz, wissen Sie. Städtische Tatoren.] Der letzte Abschnitt des Kapitels lautet dann "Požar - 1jatory" [Feuersbrunst - Latoren]. Im letzten Satz des Kapitels wird der Kalauer als Leitmotiv noch einmal zitert:

\footnotetext{
"Россия. Революция. Город из камня мертв. Кому - таторы, а кому - ляторы."

[RuBland. Revolution. Die Stadt aus Stein ist tot. Für den einen - Tatoren. Und für wieder einen - Latoren.]
}

Der Erzähler, in dessen Kompetenz diese Worte fallen, bedient sich in den tberleitungen dieser Art einer besonders stilisierten und rhythmisierten Erzählsprache. Nicht die komischen Effekte sind hier gesucht, sondern "ornamentale" Effekte, die auf syntaktischen und semantischen Parallelismen beruhen. Aus diesem Grunde haben die so gestalteten Segmente tatsächlich oft leitmotivischen Charakter. Das wird nirgends so deutlich wie in dem Roman "Golyj god", der so stark an dem Vorbild der Romane Andrej Belyjs orientiert ist:

\footnotetext{
"В городе - голод, в городе - скорбь и радость, в городе - слезы и смех. Над городом идут весны, осени и зимы. По новой дороге ползут мешечники, оспа и тиф." .
}

[In der Stadt gibt es Hunger, in der Stadt gibt es Leid und Freude, in der Stadt..gibt es Tränen und Lachen. Uber die Stadt ziehen Frühling, Herbst und Winter hinweg. tber die neue Straße kriechen Hamsterer, Blattern und Typhus.] 
Solche ornamentalen, im Prinzip immer parataktischen Reihungen begegnen vorzugsweise an den strukturell auffälligen Schalt- und Umschaltstellen, sowie am Anfang und am Ende der Kapitel und des ganzen Romans. Nach der "Einleitung" ("Vstuplenie") beginnt die "Demonstration" ("Izloženie") des Romans mit den Sätzen:

"В городе, городское, по городскому. Древний город мертв. Городу тысяча лет."

[In der Stadt, was der Stadt zukomnt, auf städtische Weise. Die alte Stadt ist tot. Die Stadt ist tausend Jabre alt.]

Dieses eigentlich von den Symbolisten ererbte Thema der "toten Stadt" (notwendig erscheint mir der Hinweis auf D'Annunzios Drama "La città morta" und auf den Roman von Georges Rodenbach "Bruges-la-morte") wird in einer neuen Variation auch in Pil'njaks Erzählung "Krasnoe derevo" [Mahagoniholz] durchgespielt.

Eigentlich ist dies eine Geschichte über "Antiquitäten", Menschen wie Gegenstände, und einen gewissen Reiz, der auch die Veröffentlichung im Ausland erklärt, macht es aus, daß zu den geliebten Antiquitäten auf der menschlichen Seite der abtrünnige Revolutionär und Sektierer Ivan Skudrin alias Ožogov gehört. Ivan ist der Bruder von Jakov Skudrin, der in "Krasnoe derevo" das Symbol für die Stagnation und Zeitlosigkeit des provinziellen Lebens ist: ein Leben zwischen Bibel und Herd. Die Stadt, die im Mittelpunkt der Erzählung steht, ist die russische Stadt Uglič, die von Pil'njak nach seinem Aufenthalt in Japan mit der mittelalterlichen japanischen Stadt Kamakura verglichen wird. Das zweite Kapitel wird daher mit folgender lakonischer "Ouverture" eingeleitet: 
"I928 год.

Город - русский Брюгге и российская Камакура. Триста лет тому назад в этом городе убили последнего царевича династии Рюрика, в день убийства с царевичем играли боярские дети Тучковы..."

[Das Jahr 1928. Die Stadt ist ein russisches Brügge und ein rußiändisches Kamakura. Vor dreihundert Jahren erschlug man in dieser Stadt den letzten Zarewitsch aus Ruriks Dynastie, am Tage des Mordes spielten mit dem Zarewitsch die Bojarenkinder Tučkov ....]

Im gleichen Atemzug werden hier Beziehungen zu dem belgischen Erzähler G. Rodenbach, zu Japan und zu Puškins "Boris Godunov" hergestellt. Der Mord an dem letzten Rurikiden Dimitrij (Demetrius), der Boris Godunov zur Last gelegt wurde, spielt hier ebenso herein wie die Gestalt des "Jurodivy" (des heiligen Narren) aus Puškins Drama, und als eine ironische Anspielung auf die Zeit Puškins soll man die Erwähnur.g eines Verwalters im städtischen Museum ansehen, der wie Puškin Zylinder und Backenbart trägt. Verschiedene Epochen sind gleichzeitig gegenwärtig, und das erweist sich bei Pil'njak vielfach als ein Gegenstück zu der geographischen "Vogelschau".

In Uglič hat inzwischen der Ausverkauf eingesetzt, der Ausverkauf an Altertümern und Artiquitäten, und an ihm beteiligen sich mehrere Personen: die schlauen Brüder Bezdetov, die Antiquitätenhändler aus Moskau, die als Aufkäufer fungieren, und der alte Jakov Karpovič Skudrin, einst Soldat, dann Gerichtsschreiber, Friedensrichter und schließlich Immobilienbesitzer, als Vermittler. Das von Jakov Skudrin gekaufte Haus ist seit den Zeiten Katharinas der Großen nicht mehr renoviert worden und in ihm spielt sich das Leben noch so ab wie vor der Bauernbefreiung, und auch die Kochrezepte stammen noch aus dem 15. oder 17. Jahrhundert. Seine Frau, Marija Klimovna, ist eine

"сухая старушка, она была чудесной женщиной, тем типом женщин, которые хранятся в России по весям вместе со старинными иконами богоматерей." 
[trockene Alte, sie war eine wunderbare Frau, jener Typ Frau, der in dörflichen Gegenden RuBlands zusammen mit alten Muttergottesikonen bewahrt geblieben ist.]

Die Familie Skudrin symbolisiert jedoch nicht nur das alte RuBland. Jakov Skudrin hat noch zwei jüngere Schwestern, die von ihm getrennt leben. Die eine, Rimma Karpovna, war vor der Revolution als Mutter eines unehelichen Kindes im Milieu der Kleinbürger auf Verachtung gestoßen, nun aber hat sie ein ganz neues Selbstgefühl gewonnen: ihre Tochter Klavdija ist Lehrerin geworden, eine ihrerseits gänzlich emanzipierte Frau und dazu Kommunistin. In diesem Lager steht auch noch Jakov Skudrins Sohn Akim, dessen Perspektive im Lauf der Erzählung dominierend wird. Akim wird vom Erzähler ausdrücklich als "Trotzkist" bezeichnet, der "den Zug der Zeit verpaßt" hat. Akim, der Ingenieur, der mit seinem Vater gebrochen hat und nur auf Besuch nach Uglič kommt, um seine Mutter, seine beiden Tanten Rimma und Kapitolina sowie seine Cousine Klavdija zu sehen.

Insgesamt folgt Pil'njak hier dem Schema so vieler sowjetischer Erzählfabeln, in denen die entscheidenden politischen Richtungen und damit auch die tragenden semantischen Oppositionen durch Glieder einer einzigen Familie repräsentiert werden. Die Konflikte innerhalb des Milieus, die hier von den Familienmitgliedern selbst ausgetragen werden, tendieren aber auch wieder dazu, mythische Züge anzunehmen, so daß man den Eindruck gewinnt, daß Pil'njak das Leben mit Hilfe des Milieus mythisiert, während bei Isaak Babel' der Mythos (der Mythos der "Reiterarmee" des Generals Budennyj, der Mythos der Juden in Petersburg, der Mythos der Juden in Odessa) durch das Milieu humanisiert und in eine unpathetischere Dimension zurückgeführt wird. 
Die Mythisierung des Milieus ergibt sich in "Krasnoe derevo" nicht allein auf der Seite der "sterbenden" Stadt, auf der Seite des "russischen Brügge", sondern auch auf der Seite der enttäuschten Revolutionäre. Nicht allein Akim hat die "richtige" politische Entwicklung als Trotzkist verfehlt, sondern in viel stärkerem Maße ist Jakov Skudrins Bruder Ivan einer der "närrischen" Idealisten, die in die historische Reihe der "Bettler", "Propheten" und "Jurodivye" [heilige Narren] hineingestellt werden. Ivan Skudrin, genannt Ožogov, hat sich 1921 nicht mit dem neuen friedlichen Leben und mit der "Neuen ökonomischen Folitik" (NEP) abfinden können, und er lebt mit seinen Gesinnungsgenossen in der Nähe des Brennofens auf dem Gelände einer teilweise verfallenen Ziegelei, wo er auf bloßem Stroh schläft. Diese "Kommune" ist der Gegenpoll zu dem kleinbürgerlich-altrussischen Milieu der Städter. Für die Altkommunisten ist Lenin bereits eine Legende geworden, ein Mythos, und sie fühlen sich als die Propheten einer versunkenen Revolution. Sie leben ohne Eigentum und ohne festen Verdienst, sie sind auf Gelegenheitsarbeiten und auf milde Gaben der Verwandten angewiesen.

In den "ornamentalen" Kommentaren des Erzählers rücken sie ganz in die Genealogie der Bettler, Pilger und Wandersänger des "heiligen RuBland" ein, auch sie finden ihre letzte Bestimmung im historisch-geographisch fixierten Milieu. Dieses Leitmotiv wird schon am Beginn des ersten Kapitels angeschlagen und im vierten Kapitel folgendermaßen variiert:

"...Нищие, побироши, провидоши, волочебники, лазари, странники, убогие, калики, пророки, юродивые, - это все крендели быта святой Руси, канувшей в вечность..." 
[... Bettler, Almosensammler, Schnorrer, Wandersänger, Bettelsänger, Wallfahrer, arme Schlucker, Pilger, Propheten, heilige Narren - das alles sind Kringel der hergebrachten Lebensweise im heiligen RuBland, das in den SchoB der Ewigkeit gesunken ist

Für Akim ist der Onkel Ivan, dessen Losungen in der Stadt diejenigen sind, die "am weitesten links" liegen, ein "Schizophrener", in der poetischeren Sprache des Erzählers aber ist er ein

"юродивый советской Руси справедливости ради, молец за мир и коммунизм."

[heiliger Narr des sowjetischen RuBland um der Gerechtigkeit willen, Wallfahrer zum Frieden und zum Kommunismus.]

Ivan Skudrin, der im Bürgerkrieg als Führer einer Partisanengruppe gekämpft hat, gehört also zu den "Kringeln" oder Schnörkeln des alten RuBland ebenso wie die Mahagonimöbel, die die beiden geschäftstüchtigen Brüder Bezdetov, die Händler aus Moskau, in der Gegend zusammenkaufen. Diese alten Möbelstücke aus Mahagoni, die der Erzählung den Titel geliehen haben, sind ebenfalls von Sonderlingen entworfen worden. Diesen "čudaki" [Sonderlingen] wird schon im ersten Kapitel eine ausführliche Digression gewidmet : jenen Meistern, die als Leibeigene nach St. Petersburg und Moskau, ja nach Paris und Wien geschickt wurden, um das Handwerk der Kunsttischlerei zu erlernen. Der historische Zeitraum seit dem Mord an dem Zarewitsch Dimitrij wird so durch eine historische Betrachtung über die Epochen des "imperialen" RuBland seit Peter I. über Elisabeth, Katharina, Paul und Alexander ausgefüllt.

\footnotetext{
"Павел - строг, Павел - мальтиец; у Павла солдатские линии, строгий покой, красное дерево темно заполировано, зеленая коха, черные львы и грифы. Александр - ампир, классика, Эллада. Николай - вновь Павел, задавленный величием своего брата Александра." Johannes Holthusen-9783954793327
} 
[Paul ist streng, Paul ist Malteser; Paul zeigt soldatische Linien, strenge Ruhe, das Mahagoni ist dunkel poliert, grües Leder, schwarze Löwen und Greifen. Alexander ist Empire, Klassik, Hellas. Nikolaus ist von neuem Paul, erdrückt von der Größe seines Bruders Alexander.\}

Babel' und Pil'njak schaffen, wie man an solchen Beispielen zeigen kann, zwei unterschiedliche Typen der "auktorialen" Erzählung. Während bei Babel' Sujet und Figuren in der Sicht und in der Wertung des Erzählers eine kompakte Einheit bilden, ist bei Pil'njak die räumlich-zeitliche Auffächerung bisweilen so groß, daß der Wechsel zwischen Personen-und Autorenperspektive das Sujet als solches berührt. Scheinbar werden die Personen vom Autor aus der perspektivischen Sicht entlassen, und gerade das, was man bei Pil'njak die "Sujetlosigkeit" genannt hat, stellt sich, unter dem Aspekt des perspektivischen Erzählens betrachtet, als eine Relativierung der Personenstandpunkte dar. Maßgebend ist allein die Geschichtsphilosophie des Autors, die Vogelperspektive also, aus der heraus er in seinen Abschweifungen die Welt betrachtet. Der natürliche Wechsel zwischen Autorenperspektive und Personenperspektive im Sinne einer Außen- oder Innenbetrachtung wird bei Pil'njak auf diese besondere Weise funktionalisiert und stilistisch wie auch semantisch deutlich betont.

L i t e r a t u r a n a b e n

B a b e l', Isaak: Izbrannoe. Predislovie I. Erenburga. Moskva 1957.

B a b e 1', Isaak: Izbrannoe. Predislovie I. Erenburga. Kemerovo 1966.

B a b e 1, Isaak: Ein Abend bei der Kaiserin. Erzählungen, Dramen, Selbstzeugnisse. Herausgegeben von Fritz Mierau. Mit Nachwort und Anmerkungen des Herausgebers. Berlin 1969.

D $r \circ z$ d a, Miroslav: Babel, Leonov, Solženicyn. Praha 1966. 
P i l'n j a k, Boris: Golyj god. Roman. Berlin 1922 (Gržebin).

P i l'n ja k, Boris: Rasplesnutoe vremja. Rasskazy. MoskvaLeningrad 1927. (Nachdruck: Russian Study Series No. 58. Russian Language Specialities. Chicago, Illinois 1966.)

P i l'n ja k, Boris: Krasnoe derevo i drugie. Nachdruck: Russian Study Series No. 65. Russian Language Specialities. Chicago, Illinois 1968.)

S t $\circ$ a $-S$ a n d o $r$, Judith: Isaac Babel' 1894-1941. L'Homme et l'oeuvre. Publications de la Faculté des Lettres et Sciences Humaines de Paris-Nanterre. Paris 1968. 


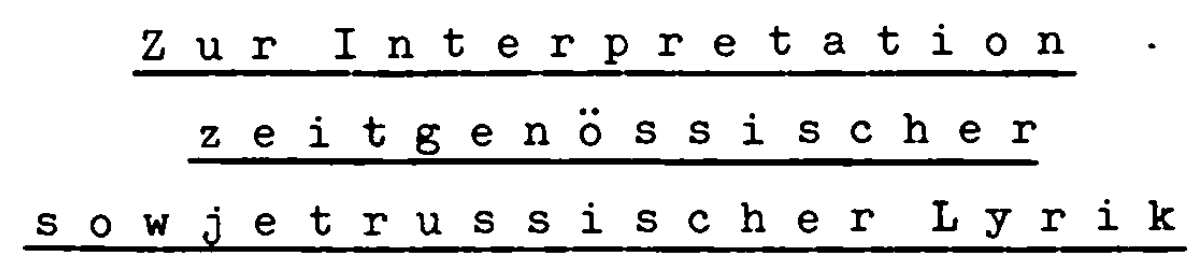

Wenn wir die Interpretation eines Gedichtes als wissenschaftliches Problem formulieren, so machen wir dabei stillschweigend die Voraussetzung, daß dem Gedicht eine bestimmte innere Ordnung eigen ist, eine bestimmte suggestive Spannung, eine Wortfügung, die die gewöhnliche Technik der sprachlichen Verständigung übersteigt und unter Umständen sogar durchkreuzt.

Mit dieser Ordnung meine ich nicht so sehr den Hintergrund der dem Leser (oder dem Zuhörer) vielleicht unbekannten oder ungeläufigen außerliterarischen Fakten, die durch einen sachlichen oder durch einen historischen Kommentar aufgehellt werden können, sondern die sprachlichen Strukturen des Gedichtes selbst. Die innere Ordnung des Gedichtes ist in erster Linie eine besondere sprachliche Ordnung, eben das, was das Gedicht von einer pragmatischen Mitteilung unterscheidet, das, was das Gedicht zum Gedicht macht.

Von dieser Voraussetzung her gesehen kann als wichtigste Aufgabe des Interpreten zeitgenössischer sowjetrussischer Lyrik keinesfalls die Klärung ihrer außerliterarischen Implikationen angesehen werden. Wenn eine in der weiten Offentlichkeit betriebene "Sowjetologie" ihre Kritik gerade auf diese Frage abstellt, so ist dazu zu sagen, daß die Methoden dieser Sowjetologie von gewissen marxistisch-leninistisch orientierten Methoden nicht gerade auffallend unterschieden

(Der Vortrae wurde erstmalig an. 8.7.1965 an der Universität Erlengen gehalten.) 
sind. Lediglich in der Auswertung der Befunde haben Plus und Minus jeweils einen umgekehrten Stellenwert. Das gerade aber macht die Gefahr einer Interpretationsweise deutlich, die mit unguter Beharrlichkeit solche außerliterarischen Ansprüche zu befriedigen sucht, die sich aus der gesinnungsmäBigen Festlegung des jeweiligen Interpreten ergeben. Die folgenden Larlegungen haben einen wesentlich anderen Zweck; sie wollen der Frage näher treten, wie einige moderne sowjetische Gedichte aussehen, und wie sie sich in ihrem literarischen Anspruch aus der Sprache selbst rechtfertigen.

Es kann heute kein Zweifel mehr daran bestehen, daß die sowjetrussischen Dichter etwa seit der Wende der fünfziger und sechziger Jahre unseres Jahrhunderts wieder auf ganz bestimmte Traditionen aufmerksam geworden sind, russische Traditionen, die vor bald zwei Menschenaltern als "Moderne" von sich reden gemacht haben.

Diese so bedeutsame und folgenreiche Epoche der Erneuerung der russischen Verssprache und der Erneuerung der Wissenschaft vom poetischen Handwerk wurde ganz sicher nur unter äuBerlichem Druck erstickt, aber sie schien ferne Vergangenheit, als Vera Sandomirsky 1957 in ihren "Notes on Soviet War and Postwar Lyrical Poetry" lapidar formulierte: "Even at its best, however, the poetry is no longer interesting to a linguist or a structural analyst."

Wird man dieses Urteil heute noch aufrechterhalten können? Ich möchte mich bemühen zu zeigen, daß sich inzwischen neue Entwicklungen abzeichnen, und daß sich von der Sprache her die Beschäftigung mit zeitgenössischer sowjetrussischer Lyrik durchaus lohnt. Dazu seien aber einige allgemein charakterisierende Bemerkungen vorausgeschickt. 
Für bezeichnend halte ich im gegenwärtigen Augenblick, daß die Thematisierung der Asthetik (und damit die Isolierung des Subjekts) so gut wie keine Rolle spielt. Diese besonders für den russischer Symtolismus und teilweise auch für den Akmeismus typische Thematik ist verdrängt von der vorwiegend sozial bestimmten Verwicklung des lyrischen Ich mit der Wirklichkeit, mit den Ansprüchen der Gesellschaft, mit dem menschlichen Gegenüber. Der Kult der Ästhetik ist nicht mehr modern. Auf jeden Fall herrschen beute gattungsmäßig solche Gedichte vor, die sick an der Tradition der Volksdichtung, an auffälligen Rhythmer und am konkreten Vortrag in der Offentlichkeit orientieren. Dieser Tendenz kommt diє Möglichkeit der Reproduktion durck Magnettonband und Schallplatte von seiten der Technik neuerdings er:tgegen. Eine tjpische Erscheirung aij diesem Gebiet ist z.B. der Dichter und Vortragskürst] er Bulat Okudžava, der seine Lieder selbst mit Gitarrenbegleitune vorträgt, halb als Gesang und halb als Rezitativ.

Eine Wiederauferstehurg hat auch die "Ballade" feiern können, und zwar in ihrer Eigenschaft als Vortragsstück. Eesonders zahlreich sind die Balladen bei Evgenij Evtušenko, der sich dieser Form für seine engagierten Kundgebungen gern bedient, wie 2.B. aus AnlaB des 150. Geburtstages von Lermontov mit dem Gedicht "Ballada o šefe žandarmov i o stichotvorenii na smert' poèta" [Ballade vom Polizeipräsidenten und vom Gedicht auf den Tod des Dichters] (1964).

Die Form der Ballade hat aber auch Andrej Voznesenskij in seiner Dichtung "40 liričeskich otstuplenij iz poèmy 'Treugol 'naja gruša'" [40 lyrische Abschweifungen aus dem Poem 'Dreieckige Birne'] (1962) in einem klassischen Beispiel aktualisiert: "Otstuplenie v 17 vek. Lobnaja ballada" [Abschwei- 
fung ins 17. Jhdt. Die Ballade vom Richtplatz]. Andere einschlägige Titel bei Voznesenskij sind: "Ballada-dissertacija", "Paraboličeskaja ballada" [Parabolische Ballade], sogar "Ballada točki" [Ballade vom Punkt] (vgl. "Antimiry", [Antiwelten] 1964).

Wie weit Voznesenskijs Interesse am Darbietungscharakter überhaupt geht, zeigt sich gerade an den "Digressionen" aus "Treugol'naja gruša". Die Vortragsweise ist hier häufig schon im Titel thematisiert, z.B. in den "Beatnik-Monologen" [Otstuplenija $\mathrm{v}$ vide monologov bitnikov], in dem "Otstuplenie dlja golosa i tamtama" [Abschweifung für Stimme und Tamtam] und in dem "Otstuplenie v ritme rok-n-rolla". Sicher sind diese als Frucht eines Amerika-Aufenthaltes entstandenen Gedichte (ebenso wie Evtušenkos Amerika-Gedicht aus $d \leqslant m$ Band "Nežnost'" [Zärtlichkeit], 1962) gröBtenteils Satiren, doch scheint es, als ob der Beatnik-Stil den beiden jungen Sowjetdichtern durchaus entgegenkomme. Von dem Wort mit dem inzwischen internationalisierten russischen Suffix (Sputnik - Beatnik - Peacenik usw.) fühlen sich beide Dichter angezogen, und Evtušenko hat in diesem Kontext nicht nur einen "Monolog bitnikov" geschrieben, sondern sogar ein Gedicht mit dem Titel "Bitnica" ("Eta devočka iz N'ju-Jorka ...") [Dieses Mädchen aus New York ....].

Bei den offensichtlich tonangebenden Vertretern der jüngeren Sowjetlyrik beeindruckt insgesamt die expressive Tendenz, die sich in dem ausdrucksvollen Spiel mit Klanggebilden ebenso zeigt, wie in der Rhythmik und in den syntaktischen Fügungen. Offenbar bemüht man sich gerade dadurch, das verloren ge- 
gangene Vertrauen zur Sprache wiederzugewinnen und die Lust an der Sprache wieder zu erwecken.

In RuBland teilen sich Symbolisten und Futuristen in das Verdienst, die Dichtung in allen ihren sprachlichen Möglichkeiten auf die Probe gestellt zu haben, und zwar ungeachtet aller ihrer sonstigen Ansprüche, Lehren und Glaubensbekenntnisse. Besonders den Futuristen ist anzumerken, wie sie die der Sprache immanente Systematik zu poetisieren bestrebt sind, sei es das phonologische System, sei es das morphologische System oder das System der Wortkombinationen. Wenn neuerdings Roman Jakobson von einer "Grammatika poèzii" spricht, dann kann man vermuten, daß er dabei auch noch auf solchen frühen Erlebnissen mit Dichtung fußt, wie er sie durch den Futurismus empfangen hat.

Jakobsons Untersuchung "Poèzija grammatiki i grammatika poèzii" (1961) ist insofern sehr anregend, als das Bild einer "Grammatik der Poesie" auch an Beispielen aus der Volksdichtung und sogar aus dem Werk Puškins erhärtet wird. Wahrscheinlich hat Jakobson recht mit seiner an anderer Stelle gemachten Bemerkung, die slavischen Sprachen seien "typically grammatical languages" (Style and Language, New York 1960, S. 100). Das würde dann für die phonematischen Korrelationen ebenso gelten wie für den Flexionsreichtum, für die suffixalen Ableitungsmöglichkeiten und damit auch für die semantischen Variationseffekte.

Tatsache ist, daß der russische Futurist Velimir Chlebnikov, über den R. Jakobson schon vor 45 Jahren geschrieben hat, die poetische Sprache in vorher kaum denkbarer Weise verwandelt hat. Man kann sagen, daß seit Chlebnikov praktisch alle grammatischen Unterschiede direkt poetisierbar geworden 
sind. Diese Entwicklung ist noch immer nicht zum Stillstand gekommen, und gerade die gegenwärtige sowjetische Lyrik gibt sich gern als Werkstatt der Sprache, sei es im Wortspiel, in der tautologischen oder paronomastischen Wiederholung, sei es in der Wiederkehr gleicher syntaktischer Gruppen, sei es in der affektiven Wiederholung von lautlichen Elementen, von ganzen Wörtern oder Wortgruppen.

Figuren der Wiederholung und Variation von Lauten, nicht selten in der Form von Wortspielen, kann man gehäuft bei Andrej Voznesenskij antreffen. Das folgende Beispiel entstammt dem Gedicht "Staruchi kazino" [Die alten Frauen vom Kasino]

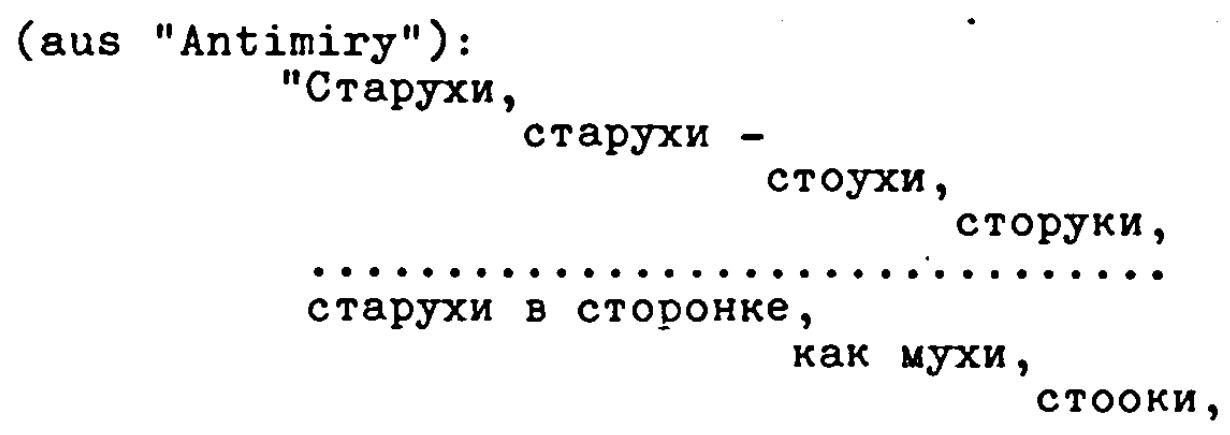

[Alte Frauen,

alte Frauen -

hundertohrig,

hunderthändig

alte Frauen seitwärts

wie Fliegen, hundertäugig ....]

Die Wiederholung ist zunächst affektiv, doch trägt das Spiel mit Worten auch stark satirische Züge, was bei Voznesenskij häufig zu beobachten ist. Dazu ein ganz eindeutiges Beispiel aus dem Gedicht "Striptiz" ("Antimiry"):

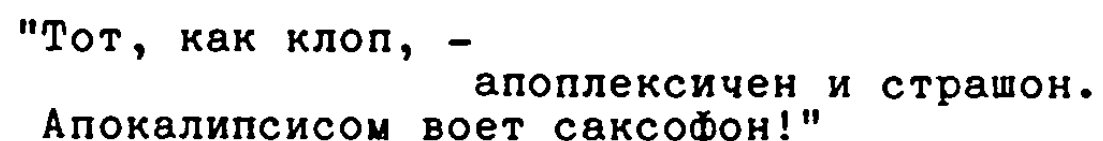


Mit dem Mittel der Paronomasie, der Wiederkehr ähnlich klingender Wörter, lassen sich sehr verschiedenartige Wirkungen erzielen. Abgesehen von den etymologischen Assoziationen (Pseudoetymologien) ist die stark affektive Komponente etwa der alliterierenden wörter nicht zu übersehen. Die Reihung bestimmter Lautfolgen in regelmäBigen Schritten kann einer flexivischen Abwandlung scheinbar angenähert werden, und die Wiederholungen bekommen dann einen pseudosystematischen (paradigmatischen) Charakter. Als Beispiel möchte ich hier Voznesenskijs Gedicht "Gojja" ("Antimiry") anführen, das auf einem solchen Effekt aufgebaut ist:

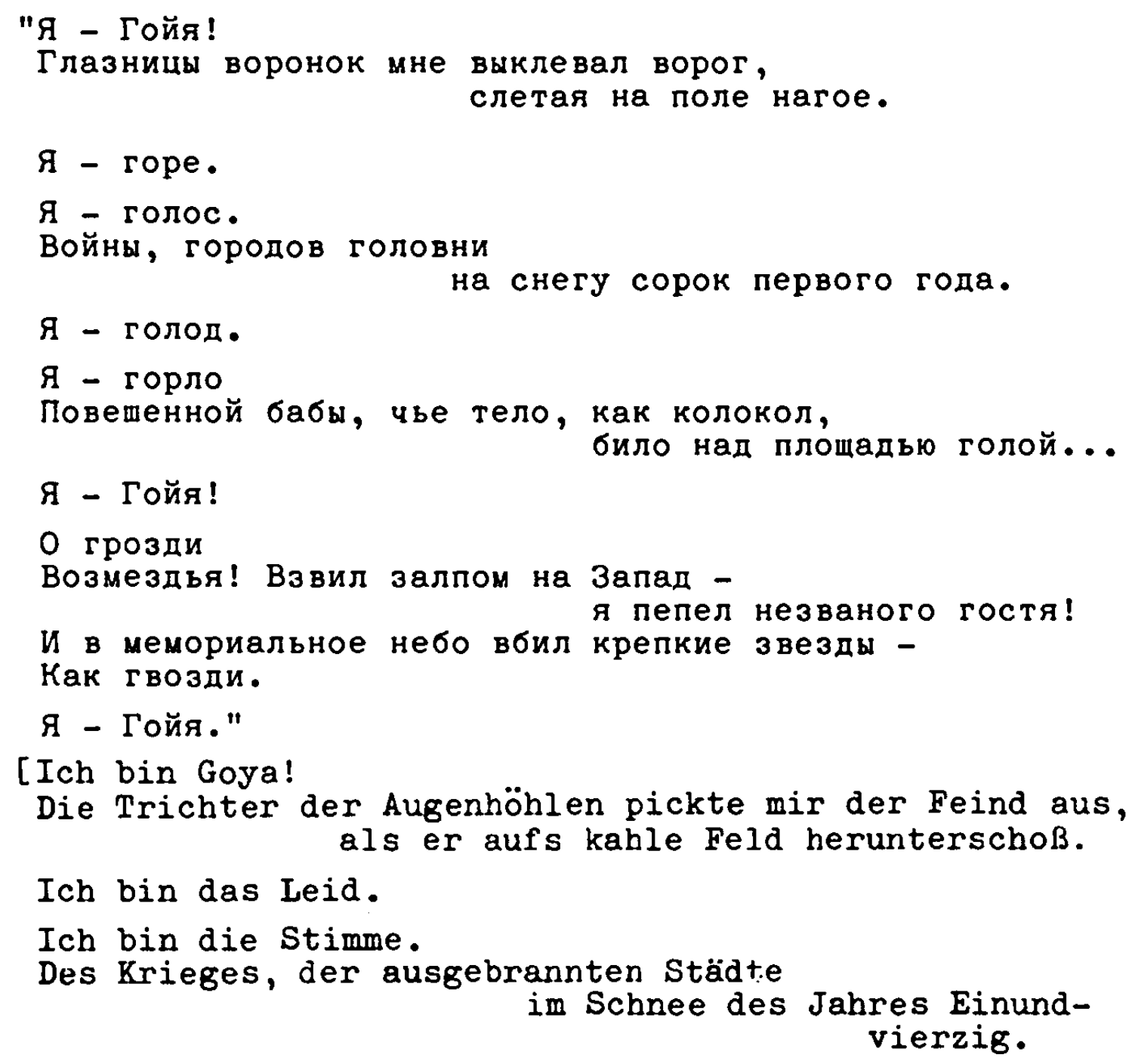

Ich bin das Leid.

Ich bin die Stimme.

Des Krieges, der ausgebrannten Städte im Schnee des Jahres Einundvierzig.

Ich bin der Hunger.

Ich bin die Kehle

der erhängten alten Frau, deren Körper wie eine Glocke über dem nackten Marktplatz 
Ich bin Goya!

o Trauben der Vergeltung! Mit einer Salve nach Westen habe ich weggeblasen - die Asche des ungeladenen Gastes!

Und in den Himmel des Gedenkens habe ich dauerhafte Sterne geschlagen -

wie Nägel.

Ich bin Goya.]

Die Kette "Ja Gojja - Ja gore - Ja golos - Ja golod - Ja gorlo" wird zu einem "grammatischer" Pseudoparadigmal, wobei sich hier das Wortspiel als blutiger Ernst entpuppt. In dem Gedicht wird ja das Jahr 1941 beschworen, Erieg und Schrecken des Krieges. Emotional gesehen können solche Wortspiele wiederum ganz verschiedenartige Funktionen erfüllen. Ob komische oder tragische Begleitfunktionen auftreten, hängt vom Ganzen der semantischen Bezüge ab.

Der affektive Charakter der Lautwiederholungen spricht in dem Gedicht für sich selbst. Dominierend erscheinen die Lautgruppen -oro-, -olo-, -ro-, -10- und deren Umkehrungen. Im zweiten Teil des Gedichtes dominieren daneben -z-, -zdund $-z v-$.

Von nicht geringerer Bedeutung als das, was Symbolismus und Futurismus der jungen sowjetischen Lyrik als Erbschaft hinterlassen haben, scheint mir die russische Volksdichtung zu sein. Das folgende Beispiel stammt aus Voznesenskijs Verserzählung (poèma) mit dem Titel "Mastera"[Die Meister] (ebenfalls in "Antimiry"):

1 Eingehend ist die Form dieses Gedichtes inzwischen interpretiert in: Lotman, Jurij: Lekcii fo struktural'noj poetike. Tartu 1964. (=Trudy po znakovym sistemam. 1.) Vgl. auch Ju. Lotman: Struktura chudožestvennogo teksta. Moskva 1970. 


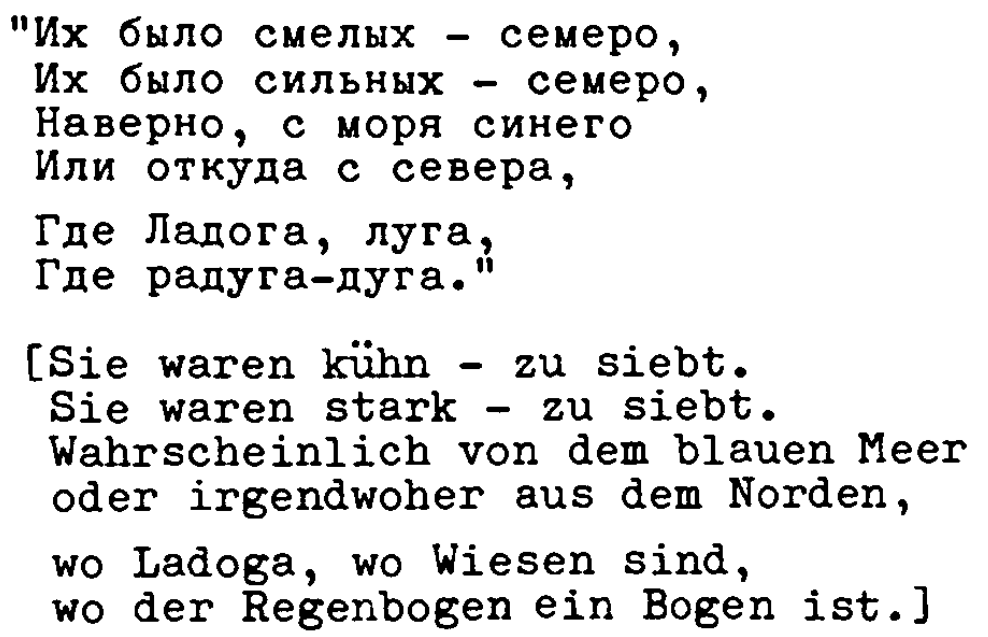

Das Wortspiel "Ladoga-luga" "raduga-duga" hat in diesem Zusammenhang eine vorwiegend ornamentale Funktion, ist Bestandteil des "style russe", zusammen mit "morja sinego" und zusammen mit dem ganzen Rhythmus. Voznesenskij verwendet hier den dreihebigen jambischen Vers, den wir aus Nekrasovs "Komu na Rusi žit' chorošo" kennen, und auch die daktylischen Klauseln sind Bestandteil der volkssprachlichen Stilisierung.

Solche folkloristischen oder pseudofolkloristischen Elemente findet man in der sowjetischen Gegenwartslyrik so häufig, daß es sich erübrigt, eine größere Zahl von Beispielen anzuführen. Durchgehende Stilisierung weist etwa das folgende Gedicht von Bulat Okudžava auf, das sich in der Sammlung "Proza i poèzija" [Prosa und Lyrik] ( $\left.{ }^{3} 1968\right)$ findet:

\footnotetext{
"А как первая любовь - она сердце жжет, а вторая любовь - она к первой льнет, ну, а третья любовь - ключ дрожит в замке, ключ дрожит в замке, чемодан в руке.

А как первая война - да ничвя вина,

а вторая война - чвя-нибудь вина,

a как третья война - лишь моя вина,

а моя вина - она всем видна.

А как первый обман - на заре туман,

а второй обман - закачался пьян,

а как третий обман - он ночи темней, он ночи темней, он войны страшней."
} 
Wenn's die erste Liebe ist, entzündet sie das Herz, und wenn's die zweite Liebe ist, schmiegt sie sich an die erste, na, und wenn's die dritte Liebe ist, zittert der Schlüssel im SchloB, zittert der Schlüssel im Schloß, der Koffer in der Hand.

Wenn's der erste Krieg ist, hat niemand dran Schuld. Und wenn's der zweite Krieg ist, hat irgend jemand dran Schuld,

und wenn's der dritte Krieg ist, hab ich allein Schuld und meine Schuld ist allen sichtbar.

Und der erste Betrug ist wie ein Nebel am frühen Morgen, und der zweite Betrug taumelte wie ein Besoffener, und der dritte Betrug ist dunkler als die Nacht, ist dunkler als die Nacht, schrecklicher als der Krieg.]

In dem Gedicht ist das volkstümliche Prinzip des dreigliedrigen Parallelismus vollkommen durchgeführt, und die Verse können ohne weiteres mit Versen aus der Volksdichtung assoziiert werden, genauer gesagt mit dem Bylinenvers. Sprache und Rhythmus der Byline sind hier in der ganzen Motorik imitiert, und durch ständige syntaktische Wiederholungen wird das Prinzip des Isokolon nachdrücklich betont.

Auch bei der Dichterin Bella Achmadulina treten volkstümliche Elemente häufig zutage, gelegentlich in Kombination mit Wortspielen. Die beiden ersten Strophen eines Gedichtes aus dem Bändchen "Struna" [Die Seite] (1962) können das veranschaulichen:

\footnotetext{
"Человек в чисто поле выходит, травку клевер зубами берет. у него ничего не выходит. Все выходит наоборот.
} 
И в работе опять не выходит.

И в любви, как всегда, не везет.

что же он в чисто поле выходит, травку клевер зубами берет?"

......................

[Ein Mensch geht ins freie Feld, hält ein Kleeblatt zwischen den Zähnen. Und es kommt gar nichts dabei heraus. Alles entwickelt sich falsch herum.

Und auch in der Arbeit gelingt wieder nichts. Und in der Liebe hat er wie immer kein Glück. Wozu soll er überhaupt ins freie Feld gehen, ein Kleeblatt zwischen den Zähnen halten?]

Die mehrfache Wiederholung des Wortes "vychodit" bzw. "ne vychodit" gibt im Wechsel der lexikalischen Bedeutungen (hinausgehen / herauskomen) den Strophen ihren eigenen "grammatischen" Bezug. Ein charakteristisches "grammatisches" Wortspiel findet sich in einem anderen Gedicht der Achmadulina, ebenfalls aus der Sammlung "Struna":

"Светофоры. И я перед ними становлюсь, отступаю назад. Светофор. Это странное имя. Светофор. Святослав. Светозар.

Светофоры добры, как славяне. Мне в лицо устремляют огни и огнями, как будто словами, умоляют: Постой, не гони."

[Verkebrsampeln. Und ich bleibe stehen vor ihnen, trete zurück. Verkehrsampel. Das ist ein merkwürdiger Name. Verkehrsampel. Syjatoslav. Svetozar.

Die Ampeln sind gut wie Slaven.

Sie richten mir ihr Licht ins Gesicht und sagen mit ihren Lichtern wie mit Worten: Bleib einen Augenblick stehen, renn nicht.] 
Das Wort "svetofor" (Lichtampel, Signalampel) wird hier "pseudosystematisch" in die Kategorie der slavischen Personennamen eingereiht, in der Form einer direkten Paronomasie. Der Vers "die Lichtampeln sind gut wie Slaven" hat so nur im Zusammenhang des russischen Textes (vermittelt durch das Wortspiel) einen greifbaren Sinn.

Zu einer anderen Art von komischer Systematik gelangt Andrej Voznesenskij durch die Semantik der Wortkompositionen mit dem Bestandteil "anti-" in seinem Gedicht "Ironiko-filosofskoe" mit dem Untertitel "Antimiry" ("Treugol'naja gruša"). Aus der Vorstellung der "Antimaterie" schöpft Voznesenskij seinen Stoff, der zu einem Spiel mit absurden Oppositionen wird :

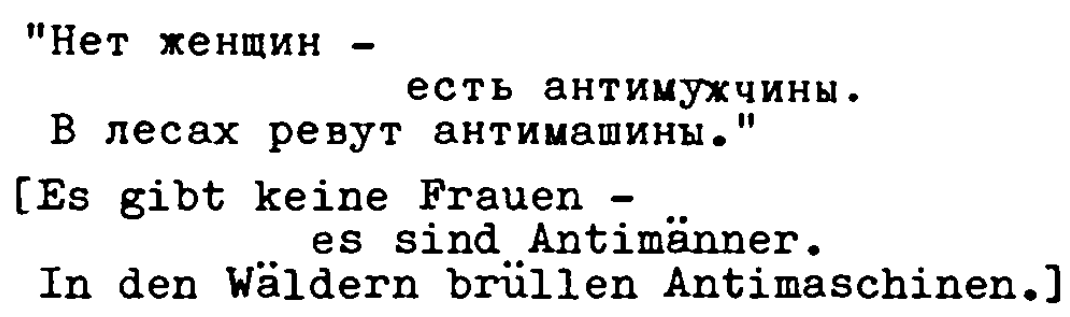

Die Opposition Tier-Maschine ist durch die pseudowissenschaftliche Bildung "antimašiny" ausgedrückt, jedoch folgt dem grotesken Reim "antimužčiny / antimašiny" auf dem Fuß eine "echte" Oxposition mit weitreichenden Assoziationen:

"Есть соль земли. Есть сор земли."
[Es gibt das Sa]z der Erde. Es gibt den Schmutz der
Erde.] In diesem Vers ist die Phonemopposition $I^{\prime}-r$ identisch mit der biblischen Sphäre ("Salz der Erde") einerseits und dem Abfallhaufen (Unrat, Schmutz) auf der anderen Seite der Opposition.

Ein ernstes Spiel mit Paronomasien, aus denen eine binäre Opposition konstruiert ist, zeigt auch Evtušenkos Gedicht 
"Puškin" (aus "Nežnost""), das mit der folgenden Apostrophe anhebt:

\author{
"О, баловень балов \\ и баловень боли!" \\ [0, Liebling der Bälle \\ und Liebling des Schmerzes!]
}

Der Opposition bal - bol' (mit "innerer Flexion" in der Terminologie der Futuristen, Opposition a - o ) steht hier noch das Wort "baloven'" gegenüber, das etymologisch an keine der beiden Seiten anzuschließen ist.

Wie verbreitet die Tendenz zum grammatischen Spiel ist, kann man auch an Iosif Brodskij sehen, der dem Vernehmen nach 1964 von einem Leningrader Gericht zu einer Strafe von nicht unerbeblicher Dauer verurteilt wurde. Brodskijs im Ausland herausgegebene Gedichte ("Stichotvorenija i poèmy", New York 1965) zeigen eine sehr eindeutige Neigung zur "Grammatik der Poesie", die sich hier vielleicht noch klarer ausspricht als bei den bisher erwähnten Vertretern der jüngeren Generation. Einer besonderen Interpretation wäre etwa Brodskijs Verfahren in der John Donne gewidmeten "Bol'šaja èlegija" [Große Elegie] wert, und daß Brodskij eigens über die grammatischen Kategorien reflektiert, beweist das Gedicht mit dem Titel "Glagoly" [Verben]. Aus vielen möglichen Beispielen sei hier zunächst das Sonett herausgegriffen, in dem das Prinzip der pseudoparadigmatischen Variation besonders $\mathrm{klar}$ in Erscheinung tritt. Das Gedicht ist zwar für sowjetische Verhältnisse schon fast ungewöhnlich zu nennen, doch führt es lediglich mit großer Konsequenz Versuche weiter, die offenbar "in der Luft" liegen: 
"Сонет

Перехиви всех.

Переживи вновь, словно они - снег,

пляшущий снег снов.

Переживи углы.

Перехиви углом.

Перевяжи узлы

мехду добром и злом.

Но перехиви миг.

и переживи век.

Переживи крик.

Переживи смех.

Переживи стих.

Переживи всех."

[ SONETT

Halte alle durch.

Halte aufs neue durch,

wie wenn sie bloB Schnee wären,

der wirbelnde Schnee der Träume.

Halte die Winkel durch.

Halte im Winkel durch.

Verbinde die Knoten

zwischen Gut und Böse.

Aber durchlebe den Augenblick.

Und durchlebe diese Zeit.

Durchlebe den Schrei.

Durchlebe das Lachen.

Durchlebe den Vers.

Halte alle durch.]

Die Abwandlung der einzelnen Zeilen erfolgt systematisch und in fast minimalen Schritten. Nur die dritte und vierte Zeile im ersten Quartett und die vierte Zeile im zweiten Quartett enthalten keinen Imperativ. Das Grundwort "pereživi ..." stellt eine klare Dominante dar und wird nur einmal zugunsten eines Wortspiels aufgegeben: Pereživi uglom / Perevjaži uzly. Die einsilbigen Wörter in den Terzetten erscheinen wie wechselnde "Suffixe", was den Eindruck einer Pseudo-Flexion hervorruft: Die Variationen von "pereživi mig" können daher pseudoparadigmatisch genannt werden. Viele Gedichte von Brodskij gewinnen durch die scheinbar monotone Wiederholung 
eine beschwörende Eindringlichkeit, die vielleicht nicht ungewollt an die Dichtung der primitiven Völker erinnert. Die moderne Dichtung hat sich ja längst wie die Malerei den ganzen Umkreis der menschlichen Zeichensysteme eröffnet. Es ist gar nicht so weit hergeholt, wenn man sich heute für "primitive" Kunstformen wie Kinder- und Abzählverse interessiert (H.M. Enzensberger), wenn man wie Paul Celan in der "Niemandsrose" (1963) kultische und religiöse Poesie in völlig neuartiger Form wieder zum Sprechen bringt:

\footnotetext{
"Niemand knetet uns wieder aus Erde und Lehm, niemand bespricht unseren Staub. Niemand." ("Psalm")
}

Die moderne Poesie hat gelegentlich unbedingt etwas mit rituellen Gebräuchen zu tun, auch wenn das Ritual auf die Sprache beschränkt bleibt.

Eines der interessantesten kürzeren Gedichte Brodskijs, das unter dem Titel "Ryby zimoj" [Fische im Winter] abgedruckt ist, zeigt deutlich noch einen kultischen Hintergrund:

"Рыбы зимой

Рыбы зимой живут.

Рыбы жуют кислород.

Рыбы зимой плывут, задевая глазами

Туда. лед.

Где море.

Рыбы.

$$
\text { Рыбы. }
$$

$$
\text { Рыбы. }
$$

Рыбы плывут зимою.

Рыбы хотят выплыть.

Рыбы плывут без света.

Под солнцем зимним и зыбким.

Рыбы плывут от смерти

вечным путем рыбьим.
Рыбы не льют слезы; упираясь головой

в холодной воде в глыбы, мерзнут холодные глаза рыбы. рыбы ибо они безмолвны. Стихи о рыбах, встают поперек как рыбы, горла." 


\section{[FISCHE IM WINTER}

Fische leben im Winter.

Fische kauen Sauerstoff.

Fische schwimmen im Winter,

und stoßen dabei mit den Augen ans Eis.

Dort. Wo es tiefer ist.

Wc das Meer ist.

Fische.

Fische.

Fische.

Fische schwimmen im Winter.

Fische wollen herausschwimmen.

Fische schwimmen ohne Licht.

Unter der Sonne

der winterlichen, der unsteten.

Fische schwimmen dem Tod davon

auf dem ewigen

Fischweg.

Fische vergießen keine Tränen,

Sie vergraben den Kopf in einem Erdklumpen, im kalten Wasser

frieren

die kalten Augen des Fisches.

Fische.

weil sie

Immer sind sie schweigsam,

sprachlos sind.

Gedichte über Fische

stellen sich wie Fische

quer

in der Kehle.]

Man kann hier schwer der Versuchung widerstehen, hinter

den Fischen eine bestimmte Symbolik zu sehen. Im Tierkreis

gehören die Fische zur Winterszeit, doch hat der Fisch gerade mit Erneuerung und Wiedergeburt zu tun. C.G. Jung schroibt in seinem Buch "Symbole der Wandlung" über den Fisch: "Der Fisch hat in den Träumen gelegentlich die Bedeutung des ungeborenen Kindes, denn dieses lebt vor seiner Geburt im Wasser, wie ein Fisch; und die Sonne wird, indem sie ins Meer taucht, Kind und Fisch zugleich." Bekannt ist ja auch die christliche Symbolik des "Ichthys", des Fisches, und man darf in diesem Zusammenhang auch den Fisch nicht unerwähnt lassen, der sich so häufig auf den Bildern von Marc Chagall vorfindet. Brodskij, der ebenfalls aus einer jüdischen Familie stammt, bietet in 
seinen Gedichten so viele religiöse Anspielungen, daB man hier nicht an einen Zufall glauben mag.

Die Engführung der Thematik (Fisch - Winter - Eis Dunkelheit - Sehnsucht nach dem Licht - Tod - Kälte - Schweigen) steht in engstem Zusammenhang mit dem sprachlichen Verfahren. Bestandteil dieses Verfahrens ist auch die "tautologische" Wiederholung, die in der Poesie der verkürzten Schritte so häufig begegnet. Für keinesfalls abwegig halte ich wiederum den Vergleich mit Paul Celan, der einen 1959 veröffentlichten Gedichtband ganz programmatisch "Sprachgitter" genannt hat. Zumindest könner: Bemühungen der deutschen Dichtung die Haltung zu illustrieren helf $\in$, die sich bei Brodskij ausspricht.

\footnotetext{
"Augen weltblind, Augen im Sterbegeklüft, Augen Augen:...."
}

so heißt es in Celans Gedicht. "Schneebett". Dazu noch ein anderes Beispiel:

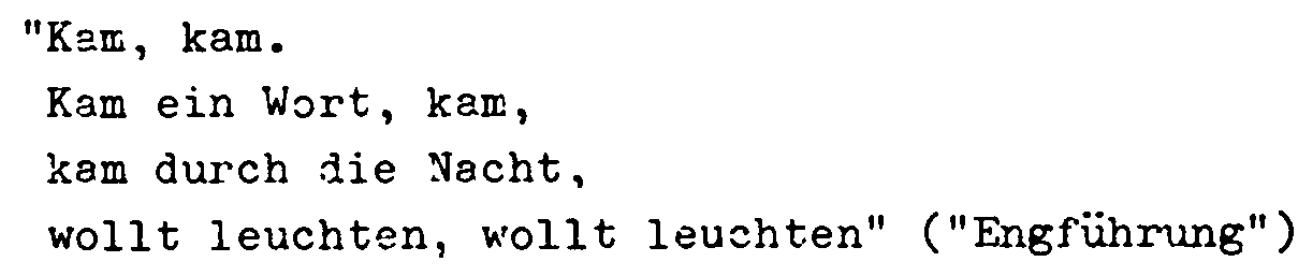
Diese Poesie der "Sprachgitter" und der "gremmatischen Meditatioren" (Helmut Heißenbüttel: "Topographien", 1955) ist ganz sicher nicht schlechthi:i die Poesie von houte. Kein Zweifel kanu aber daran bestehen, daß hier ein bestimmter Zeitstil am Werk ist, der auch in Rußland weiter wirksam ist. Mögen auch die Extremisten in den Untergrund verbannt bleiben wie die der Sage nach existierende Zeitschrift "Sintaksis" und andere inoffizielle Literatur - , folgenlos sind diese Entwicklungen auch in Rußland keineswegs geblieben. 
Auch bei konventionelleren Dichtern erfreut sich das Prinzip der tautologischen Wiederholung großer Beliebtheit. Man kann etwa bei Robert Roždestvenskij sehen, wie sich die Poesie der verkürzten Schritte zu einer eigenen Manier entwickelt. Als typisch darf man etwa Roždestvenskijs Gedicht "Neobitaemye ostrova" [Die unbewohnten Inseln] ansehen, das 1962 in dem gleichnamigen Band erschien, wie der folgende Ausschnitt zeigt:

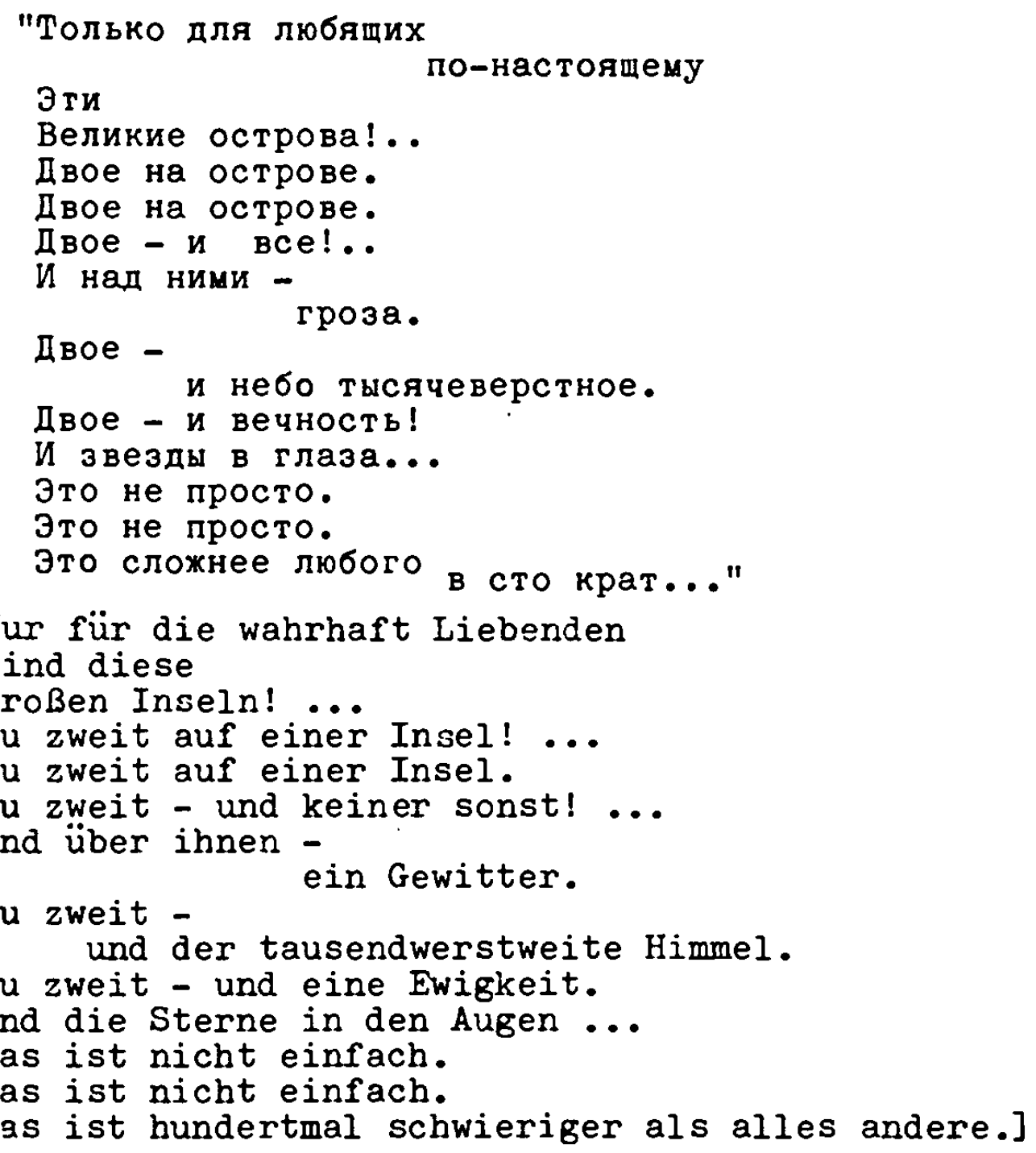

Das Stilprinzip, das sich als Dominante herausstellt, ist die Wiederholung (Anaphora, tautclogische Wiederholung bestimmter Wortgruppen, Parallelismus bestimmter syntaktischer Einheiten). Für die Liebenden verwandelt sich die Großstadt in eine 
einsame Insel, und die urbane Landschaft schrumpft zusammen auf eine Zone voll zeichenhafter Bedeutungen. Das Thema der Insel taucht gleich am Anfang auf und wird in Engführung mit allen anderen Gedanken stets weiter durchgehalten. Folgendermaßen lauten die ersten Zeilen des Gedichtes:

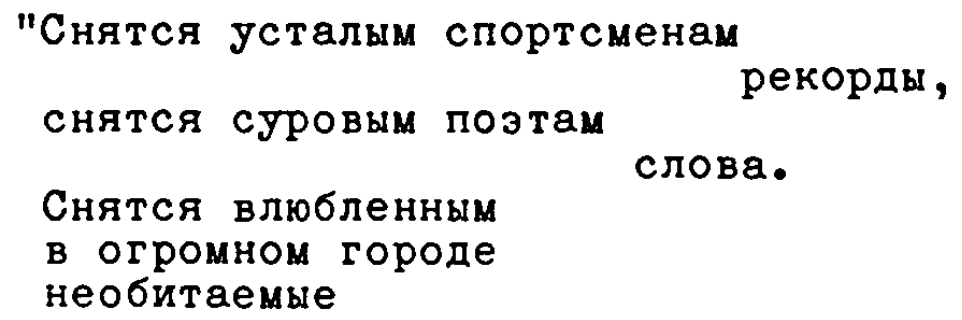

$$
\text { острова." }
$$

[Es träumen die müden Sportler

es träumen die strengen Dichter

Es träumen die Verliebten

$$
\text { Wörter. }
$$

in der Großstadt

unbewohnte

\section{Irseln.]}

In der durchgehenden Anaphora der ersten drei Verse zeichnet sich bereits das Prinzip der Wiederholung und der verminderten Schritte ab, bis am Schluß eine letzte tautologische Wiederholling (das Verlöschen der Ferster) die Beweging zum Stillstand bringt:

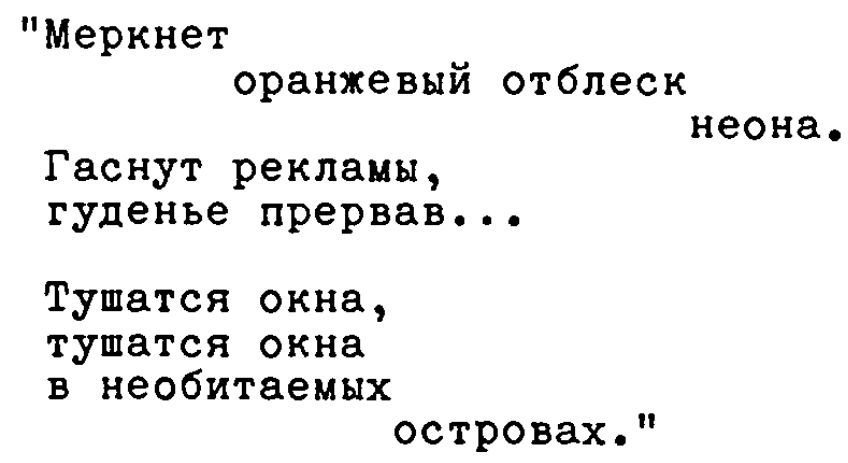

[Es verbla Bt

$$
\text { der orangefarbene Reflex }
$$

Die Reklamenverlöschen, das Summen ist unterbrochen ...

Es gehen die Fenster aus,

es Gehen die Fenster aus, auf den unbewohnten 
In der beständigen Wiederholung steckt immer etwas Beschwörendes, und auf eine solche Beschwörung, die Beschwörung der Toten, läuft R. Roždestvenskijs "Rekviem" (erschienen in "Neobitaemye ostrova", 1962) hinaus. Es handelt sich um ein "Requiem" für die Gefallenen des letzten Krieges, das Gedicht ist dem Gedächtnis der Gefallenen gewidmet. Besonders eindrucksvoll sind Klage und Mahnung der Toten, die Stellen, an denen die Beschwörung ausdrücklich thematisiert wird:
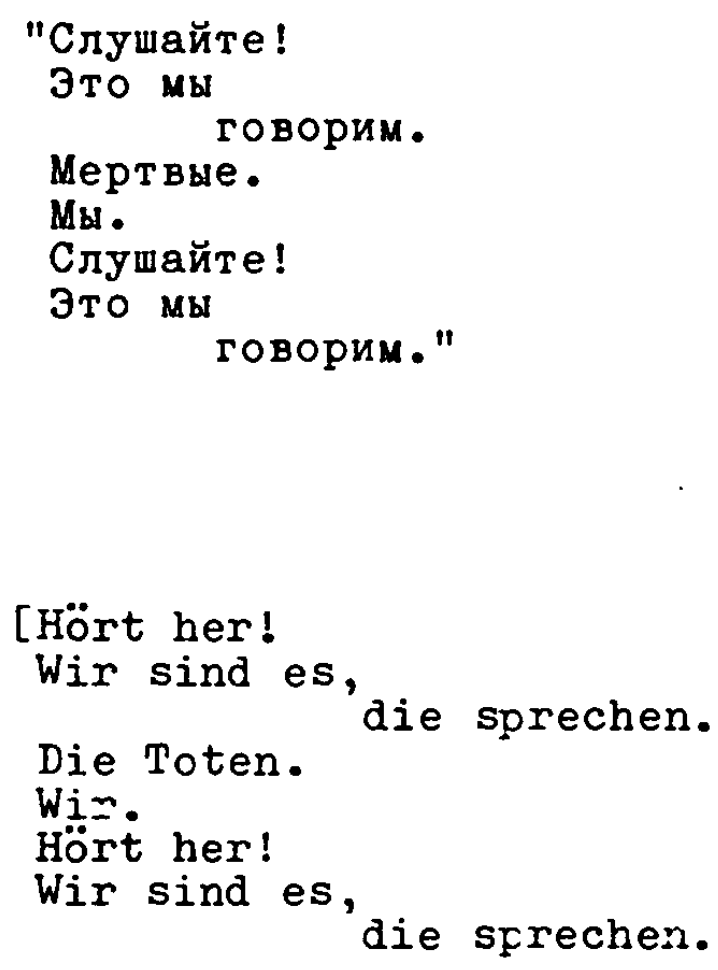

Auch wenn der kritischere Beobachter hier Arklänge an Majakovski,j heraushören wird (den charakteristischen Inperativ "Slušajte!" [Hört her!]), und auch wenn Robert Roždestvenskij im Vergleich zu Brodskij $\epsilon$ inen ausgesprochenen tberschul an trivialer Rhetorix aufweist, lassen sich auch hier Tendenzen ablesen, die ein gan? starkes Gewicht gewonnen haben.

Die "tautologische" Wiederholung (bei eventuell variierter Sinngebling) ist auch ein Bompositionsprinzip der schon 
erwähnten Lieder Bulat Okudžavas, und ein Okudžava gewidmetes Gedicht E. Evtušenkos ("Djadja Vasja" [Onkel Vasja]) zeigt gerade in seinen Anfangs- und Schlußzeilen, daB Evtušenko dieses Prinzip als Dominante verstanden hat:

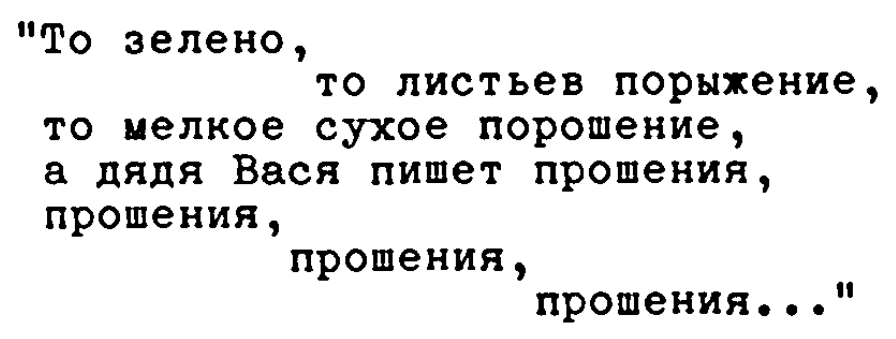

[Bald das Grün, bald der Blätter rötlicher Schimmer, bald ein feines trockenes Bestreuen und Onkel Vasja schreibt Bittgesuche, Bittgesuche,

Bittgesuche, Bittgesuche.]

Wiederholung, Variation und asyndetische Reihung sind ganz besonders ein typisches Element der Gedichte Iosif Brodskijs, wo man auch darauf aufmerksam wird, wie sehr sich die sprachliche Gestaltung vergangenen Traditionen (namentlich des Barock) annähern kanr. Solche Rückgriffe gelingen allerdings am häufigster innerhalb spezifischer thematischer Kontexte, und das zeigt besonders gut der Anfang der "Bol'šaja èlegija" [Große Elegie] auf John Donne. Der Tod ist es, der hier als in der Stille um sich greifendes Ereignis vom entschlafenen Dichter auf die. Welt der Dinge übergreift:

\footnotetext{
"Дхон Донн уснул, уснуло все вокруг, Уснули стены, пол, постель, картины, уснули стол, ковры, засовы, крюк, весь гардероб, буфет, свеча, гардины. уснуло все..."
} 
[John Donne ist eingeschlafen, eingeschlafen ist alles ringsum, eingeschlafen sind die Wände, der Fußboden, das Bett, die Bilder, eingeschlafen der Tisch, die Teppiche, die Riegel, der Haken, die ganze Garderobe, das Bafett, die Kerze, die eingeschlafen ist alles ....]

Die asyndetische Reihung der Substantive führt zu einer Wortakkumulation, die aus der Barockdichtung gut bekannt ist, und die hier zwar in erster Linie die durchschnittenen Verbindungen der Dinge untereinander bezeichnet, aber auch die konkrete historische Dimension öffnet. Die "grammatische" Poesie steht deshalb grundsätzlich auBerhalb der Antinomie "modern" - "unmodern".

L i t e r a t u r a n g a b e n

A c h m a d u l i n a, Bella: Struna. Moskva 1962.

B $r \circ d s k i j$, Iosif: Stichotvorenija $i$ poemy. New York 1965.

C e 1 a n, Paul: Die Niemandsrose. Frankfurt/M. 1965.

C e 1 a n, Paul: Sprachgitter. Frankfurt/M. 1959.

E $v$ t u š e n k o, Evgenij: Nežnost'. Novye stichi. Moskva 1962 .

$\mathrm{J}$ a $\mathrm{k} \circ \mathrm{b} \mathrm{s} \circ \mathrm{n}$, Roman: Linguistics and Poetics. In: Style and Language. Ed. by Thomas A. Sebeok. New York 1960.

$\mathrm{J} a \mathrm{k} \circ \mathrm{b} \mathrm{s} \circ \mathrm{n}$, Roman: Poèzija grammatiki i grammatika poezii. In: Poetics - Poetyka - Poètika. 's-Gravenhage Warszawa 1961 .

J u n B, C. G.: Symbole der Wandlung. Analyse des Vorspiels zu einer Schizophrenie. Zürich ${ }^{4} 1952$.

0 k u d ža v a, Bulat: Proza i poézija. Frankfurt/M. ${ }^{3} 1968$.

$R \circ z$ d e s $t$ ve n $s$ k j, Robert: Neobitaemye ostrova. Moskva 1962.

$S$ a $n$ d o m $i r$ s $\mathrm{y}$, Vera: The Sad Armchair: Notes on Soviet War and Postwar Lyrical Poetry. In: Harvard Slavic Studies 3, 1957.

$\mathrm{V} \circ \mathrm{z} \mathrm{n}$ e $\mathrm{s}$ e $\mathrm{s} \mathrm{k} i \mathrm{j}$, Andrej: Antimiry. Izbrannaja lirika. Moskva 1964.

$\mathrm{V} \circ z \mathrm{n}$ e s e n s ki j, Andrej: 40 liričeskich otstuplenij iz poémy 'Treugol'naja gruša'. Moskva 1962. 


\section{Probleme der neueren \\ sow jet literatur \\ (Versdichtung)}

In meinem Vortrag möchte ich mich aus triftigen Gründen auf die Entwicklung der Lyrik im Verlauf ungefähr des letzten Jahrzehntes (seit der Wende der 50er und 60er Jahre) beschränken.

Rein hypothetisch kann man, glaube ich, in Kenntnis der legal veröffentlichten literarischen Produktion der letzten Jahre unterstellen, daß sich die innerliterarische Evolution vor allem im Bereich der Versdichtung vollzogen hat, während in den Gattungen der erzählenden Prosa vergleichbare Innovationen kaum stattgefunden haben oder jedenfalls nicht nach außen gedrungen sind. Ich denke hierbei nicht lediglich an Probleme des innerlichen Strukturwandels, sei es in der Semantik, in der Syntax oder auf der Ebene der Komposition (d.h. in der Mikrostruktur oder Makrostruktur der einzelnen Werke), sondern auch an die moralische und gesellschaftliche Bedeutung der Literatur.

Keineswegs hypothetisch ist es, die Wirkung der Versdichtung, der Lyrik im strengen Sinn wie ebenfall der Versepik beim sowjetischen Lesepublikum außerordentlich hoch anzusetzen. Massen von Zuhörern beim Rezitieren von Gedichten durch ihre Schöpfer unterscheiden die sowjetrussische literarische Wirklichkeit ebenso von der unseren wie relativ hohe

(Der Vortrag wurde erstmalig gehalten am 17.3.1971 an der Universität Wien.) 
Auflageziffern von Lyrikbänden. Neue Gedichtsammlungen popuIärer Autoren wie Voznesenskij oder Vinokurov erscheinen jetzt in der Regel in Erstauflagen von 100000 Exemplaren, was, wie man immer wieder hören kann, die Nachfrage bei weitem nicht deckt.

Die moralische und gesellschaftliche Bedeutung der Versdichtung ergibt sich schon aus dem in diesem Gattungsbereich vorherrschenden Funktionstyp. Obgleich man gewohnt ist, im Rahmen der drei Bühlerschen Sprachfunktionen (Kundgabefunktion, darstellende Funktion, Appellfunktion) der Lyrik vor allem die "expressive" Kundgabefunktion zuzuweisen, dominiert in der heutigen Versdichtung eher die Appellfunktion und (in den epischen bzw. didaktischen Genera) auch die darstellende Funktion.

Geht man allein von den zwei Funktionstypen aus, die Johann Barta aus Debrecen 1961 in seinem Aufsatz "Zur Theorie der lyrischen Dichtung" aufgestellt hat, so ist entsprechend festzustellen, daß der vorherrschende Funktionstyp nicht Gefühlsausdruck und Gefühlsentladung ist, sondern "gefühlsmäßige Einwirkung und Bereicherung, Menschenformung, Appell, Agitation." Der lyrische Dichter setzt sich tendenziell und prinzipiell zum Ziel, sein Publikum zur Stellungnahme zu veranlassen, dessen Wollen und Handeln zu beeinflussen. Insofern als es sich hier um die primär nicht-ästhetischen Funktionen handelt, um die praktischen Funktionen - die ästhetischen Funktionen werden deswegen nicht geleugnet -, darf man vielleicht eine Notiz Aleksandr Bloks aus dem März 1914 anführen, in der es heißt: 
"Во всяком произведении искусства (дахе в маленьком стихотворении) - больше не искусства, чем искусства. Искусство - радий (очень малье количества). Оно способно радиоактировать все..."

[In jedem Kunstwerk (sogar in einem kleinen Gedicht) steckt mehr Nicht-Kunst als Kunst. Die Kunst ist wie Radium (sehr kleine Mengen). Sie ist imstande, alles radioaktiv zu machen.]

Halten wir fest, daß die Lyrik heute ziemlich selten und jedenfalls in sehr viel geringerem Maße als in der Zeit etwa des Symbolismus, aber auch als in der Zeit unmittelbar nach 1945 Gefühlsausdruck, Ausdruck von Emotionen oder Stimmungen zu sein scheint.

Verschieben wir die typologische Fragestellung in Richtung auf das, was B. Ejchenbaum "Melodik" genannt hat (in seinem Buch "Melodika russkogo liričeskogo sticha", Petersburg 1922), d.h. in Richtung auf syntaktische Gliederung und Intonationstypologie, so ist nicht $\mathrm{zu}$ übersehen, daß der Typus der "musikalischen" und liedhaften Verssprache, Ejchenbaums "napevnyj tip" [sanghafter Typus], deutlich ins Hintertreffen geraten ist gegenüber dem sprechtonigen Typus [govornoj tip], der gemäß Ejchenbaums Auffassung durch Anna Achmatova kanonisiert wurde. Jurij Lotman hat diese Erscheinung in seinem Buch "Lekcii po struktural'noj poetike", 1964 [Vorlesungen zu einer strukturalen Poetik] insofern neu definiert und präzisiert, als er sie schon mit der "Prosaisierung" des russischen Verses bei Puškin und mit der Kanonisierung des Enjambements im 19. Jhdt. in Zusammenhang rückt. Es handelt sich hier, wie Lotman sagt, um eine Störung des Zusammenspiels der rhythmischen und der syntaktischen Einheit der Verszeile, der ganz generell zu einem neuen Begriff des Verses führen mußte. Heute darf der "sprechtonige" Vers als Normalvers gelten, und 
der "musikalische", gesanghafte Vers ist fast ganz auf bestimmte eindeutig liedhafte Gattungen beschränkt. Bekannt ist da z.B. der Bänkelsang Bulat Okudžavas, in dem der Vers, von der Gitarre begleitet, wieder eine Geschlossenheit der intonationsmäßigen und syntaktischen Struktur aufweist:

\section{"Человек}

Дышит воздухом, дышит первой травой, камышом, пока он колышется, всякой песенкой, пока онаслышится, теплой хенской ладонью под головой. дышит, дышит - никак не надышится. Пышит матерью Дышит родиной она $\mathbf{y}$ него одна, она $\mathrm{y}$ него единственная, плачет, мучается, смеется, посвистывает, и молчит у окна, и поет дотемна, и влюбленно недолгий свой век перелистывает."

[Der Mensch

Er atmet Luft, atmet das erste Gras, atmet das Schilf, wenn ès sich leise bewegt, jedes Liedchen, solange man es hört, die warme Frauenhand unter dem Kopf. Er atmet, atmet - und kann sich nicht satt atmen. Er atmet die Mutter, - er hat nur sie, er atmet die Heimat, sie ist für ihn die einzige, er weint, quält sich, lacht, pfeift sich eins und schweigt am Fenster, und singt, bis es dunkel Und verliebt durchblättert er sein kurzes Leben.]

wird.

Beachtenswert ist in Bezug auf den Rhythmus, daB Okudžava die gefälligen syllabo-tonischen Metren gern vermeidet und einen Versbau nach rein tonischen, akzentuierenden Prinzipien wählt. Die Sprechfunktion ist hier mehr reflexiv-darstellend als expressiv, allein schon im Sinn der tberschrift, die verallgemeinernde Geltung beansprucht.

Dem sprechtonigen Typ steht neben dem musikalischen noch der deklamatorische oder rhetorische Typ zur Seite, der seinerseits bis ins 18. Jhdt. zurückreicht. Dieser Intonationstyp ist durch Majakovskij auf einer tonischen Basis neu geformt worden und hat in den 60er Jahren seine wohl eigenwil- 
ligste Ausprägung bei Andrej Voznesenskij gefunden, bei dem sich übrigens die größte Variationsbreite aller Intonationstypen findet.

Indessen scheint es mir, daB die Zahl der typischen Intonationen mindest noch um eine erweitert werden müßte, nämlich um die bewußt deformierte, "erschwerte" Intonation.

Versuche dieser Art hat neuerdings vor allem Iosif Brodskij gemacht, dessen Verse den Leser bedauerlicherweise nur in ausländischen Ausgaben erreichen. Ich denke an ein Gedicht wie "Poslanie k sticham", 1967 [Epistel an die Verse], das insofern eine Illustrierung zu Lotmans Kriterium der "Kanonisierung" des Enjambements darstellt, als hier der Zeilensprung (das "Enjambement") bewußt als durchgehendes Stilmittel gebraucht ist, als Stilmittel der Deformiemung der Verszeile. Dieses Mittel wirkt ja ästhetisch nur auf dem Hintergrund der Verszeile, auf dem Hintergrund der Erwartung einer syntaktischen Gliederung, die mit der Einteilung in Verse übereinstimmt. Diese Erwartung ist hier graphisch durch die Abgrenzung der Zeilen gegeben, bei näherem Zusehen aber auch durch den Reim bzw. die Assonanzen, die für den Reim stehen. Der trochäische Rhythmus ist - trotz fehlendem Isosyllabismus - in seiner Tendenz ein Versrhythmus.

"Послание к стихам

$$
\text { "Скучен вам, стихи мои, ящик..." }
$$

Не хотите спать в столе. Прытко

возражаете: "Быв здраву, корчиться в земле суть пытка" . Отпускаю вас. А что $\boldsymbol{*}$ ? Праву на свободу возражать - грех. Мне же хватит и других - здесь, мыслю, не стихов: грехов. Все реже сочиняю вас. Да вот, кислу мину позабыл аж даве сделать на вопрос: "Как вирши? 
Прибавляете лучей к славе?"

Прибавляю, говорю. Вы хе

оставляете меня. .......

милье стихи, в вас сердце

я свое влохил. Коль в Лету

канет, то скорбеть мне перву.

.....................

........... Все двери

настеть будут вам всегда. Но не

грустно эдак мне слыть нищу:

я войду в одне. Вы - в тыщу."

I967

[Epistel an die Verse

"Langweilig ist euch, meine Verse, die Schublade"

Kantemir

Ihr wollt im Tisch nicht schlafen. Flink erhebt ihr Einspruch: Für den Gesunden ist sich in der Erde zu krümmen eine Tortur. Ich lasse euch frei. Was soll's. Dem Recht auf Freiheit sich zu widersetzen ist eine sünde. Ich aber

habe genug andere, - hier, meine ich, nicht Gedichte, sondern Sunden. Immer seltener dichte ich euch. Nun also, ich habe seit einer Weile die saure

Miene vergessen, wenn man mir die Frage stellt: wie Fügen Sie ihrem Ruhm neuen Glanz zu? geht's den Versen?

Allerdings, antworte ich. Ihr aber

verlaßt mich. ...

Liebe Verse, in euch

habe ich mein Herz gelegt. Wenn es im Lethefluß untergeht, gerate ich als erster ins Elend.

-.....

Alle Türen

werden immer weit offen für euch stehen. Doch ich bin nicht traurig, $d a B$ ich so als Bettler gelten muB. Ich gehe nur durch eine [Tür], ihr aber durch tausend.]

Die Länge der Verszeile schwankt zwischen 8 und 10 Silben, d.h. zwischen 4 und 6 Hebungen, wobei aber schon im Achtsilber 5 potentielle Hebungen vorkommen (bei weiblichem Reim): "chvatit 'q'drugich - zdés', mbslju, -"

im Zehnsilber 6 Hebungen:

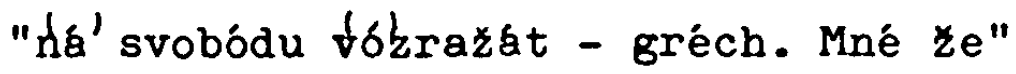

Die Erscheinung des Hebungspralls, die man früher "Spondeus" nannte und die neuerdings von Gasparov (Voprosy jazyko- 
znanija 1968, 5) wieder diskutiert worden ist, stellt eine besondere Erscheinung des tonischen Verses dar, mit einem Null-Intervall zwischen den Hebungen. Ahnlich begegnet das ja schon bei Majakovskij: (Barabannaja pesnja 1923 [Trommellied]).

"Rúku próc', vrág! [Hand weg, Feindl
Vperéd, syny stáli!" $\quad$ Vorwärts, Söhne des Stahls!]
Umstritten ist hier noch immer, ob die fehlende Senkung eine echte "Pause" darstellt, und ob man diesen Vers mit einer rhythmischen Pause ("taktometrisch") lesen muß. Der häufige Bindestrich legt diese Auffassung eigentlich nahe: "na svobodu vozražat' - grech". Zweifellos hat auch die rhythmische Struktur des Verses hier die Funktion, die geläufige Versintonation $z u$ deformieren, sie rhythmisch und semantisch zu erschweren.

Aufschlußreich ist das Motto von Kantemir, das den Einfluß des syllabischen (nicht "tonischen") Verssystems hier andeutet. Das Motto "Skučen vam, stichi moi, jaščik ..." entstammt Kantemirs "Pis'mo II, k sticham svoim" und ist Teil des ersten Verses, der ein syllabischer Dreizehnsilber mit Zäsur nach der 7. Silbe ist:

"Скучен вам, стихи мои, ящик, десять целых Где вы лет тоскуете в тени за ключами."

[Langweilig ist euch, meine Verse, die Schublade, wo ihr zehn ganze Jahre im Schatten verschlossen euch grämt!]

Ein Teilmuster des syllabischen Verses hat Brodskij hier also als Ausgangspunkt der rhythmischen Tendenz des Verses genommen, wodurch die "Erschwerung" der Form verständlich wird. Rückgriffe auf das 18. Jhdt. sind aber in der heutigen Verssprache nichts Ungewöhnliches. Sie können in dem Gedicht von Brodskij auch in Grammatik, Lexik und Bildwahl nachgewiesen werden. 
Die lyrische Sprechfunktion hängt, wenn man von allem Asthetischen einmal absieht, mit der etwas altmodischen Gattungsbezeichnung "Poslanie" [Episted] zusammen. Die Epistel hat in der russischen Versgeschichte zunächst eine reflexivdidaktische, dann eine familiär-kommunikative Appellfunktion in der Zeit Batjuškovs, Zukovskijs und des jungen Puškin. Die "Versprobe" im FluB Lethe ist u.U. eine Anspielung auf Batjuškovs Gedicht "Videnie na beregach Lety" 1809 [Vision an den Ufern des Lethe], und der Titel "Poslanie $\mathbf{k}$ sticham moim" [Epistel an meine Verse] kommt bei Batjuškov 1805 ebenfalls vor. Man darf allerdings nicht übersehen, daB die Rehabilitierung traditioneller Gattungen wie "Epistel", "Ballade", "Elegie" immer einen etwas ironischen Unterton trägt. Das gattungsbezogene Element trägt mehr den Zug eines Zitates und wird nicht mehr zu einem dominierenden Strukturelement.

Die 60er Jahre stehen im Zeichen dessen, was Zdeněk Mathauser in seinem Buch "Spirála poezie" (1967) das "offene System" nennt; die Gedichte haben sich thematisch und gattungsmäßig von allen bestimmten Postulaten befreit, und die Dichtung scheint nicht mehr durch besonders charakteristische Beziehungen des Dichters zur Umwelt, durch eindeutig festgelegte lyrische Situationen und gegenständliche Horizonte bestimmt. Insofern ist es nicht mehr sinnvoll, mit Rategorien wie "Naturlyrik", "Gedankenlyrik", "Traumlyrik", "sinnliche Lyrik", "Großstadtlyrik", "Bekenntnislyrik", "Rollengedicht" usw. zu arbeiten. Die Dichtung dringt im gegenständlichen Bereich unter die Oberfläche der realen Erscheinungen und bewegt sich im persönlichen Bereich in allen Schichten des Erlebens und Erkennens, in verschiedenen Tiefen des Bewußtseins. 
Auch der epische Fluß in der Gattung Verserzählung ("poèma"), die in der russischen Literatur eine erstaunliche Vitalität zeigt, kennt keine durchgehende Erzählsituation mehr, sondern ist polyperspektivisch angelegt und trägt oft einen ausgesprochenen Montagecharakter. Das gilt schon für Anna Achmatovas 1962 beendete "Poèma bez geroja" [Poem ohne Held], die man als Montage von Vorworten, Widmungen, Kommentaren und Gedichtsequenzen bezeichnen könnte, und auf dieser Linie liegen auch "Moja rodoslovnaja" [Mein Stammbaum] 1963 von Bella Achmadulina, "Mastera" [Die Meister] 1959 von Voznesenskij, "Oza", 1964, von Voznesenskij, "Sestvie" [Prozession] 1961, von Iosif Brodskij, "Bratskaja GES"[Wasserkraftwerk von Bratsk] 1965 von EvtiLšenkc.

In der modernen russischen Verserzählung, deren Geschich$t \Subset$ noch nicht geschrieben ist, durchdringen sicr: Historie, Satire, Gesell schaftskritik, Groteske, Agj.tation, Phantasie und Utopie. In der Verserzählung, im Poem, spricht sich der lyrische Dichter am voliständigsten aus, und diese Gattung, die auf jeden Fall eine russische Besonderheit darstellt, bietet ganz andere literarische Perspektiven als der Roman, die Kurzgeschichte oder die traditionelle Erzählform der realistischen Erzählung ["Povest"] •

Als neve Form hatte Andrej Voznesenskij 1959 schon das Poem "Mastera" [Die Meister] konzipiert, das ebenso wie das im Gleichen Jahr entstandene berühmte Gedicht "Goya" den Durchbruch zum Ruhm sicherte. "Mastera" mit dem Untertitel ("Poem aus sieben Kapiteln mit einem Requiem und Widmungen") hat Voznesenskij auch in seine folgenden Auswahlbände und Neuveröffentlichungeii immer wieder aufgenommen, diese Dichtung hat für ihn Programmcharakter. Der thematische Hintergrund auf 
der historischen Ebene ist der Bau der Vasilij-BlažennyjKathedrale an der "Krasnaja ploščad" [Roter Platz] in Moskau nach Plänen des Baumeisters Barma und die Blendung des Künstlers durch den Zaren Ivan Groznyj, der der Welt kein zweites Bauwerk von vergleichbarer Pracht gönnen wollte. Das eigentliche Thema ist allerdings das Verhältnis von Kunst und Leben, die Beschwörung von Schaffenskraft und Schaffenswillen des Volkes mit dem Dichter Voznesenskij an der Spitze. Das "Requiem" setzt antithetisch oder dialektisch den Willen zum Aufbau gegen den Willen zur Zerstörung, es endet mit der utopischen Phantasie vom Flug in die Zukunft. Voznesenskij, der ehemalige Architekturstudent, schildert so seinen Traum:

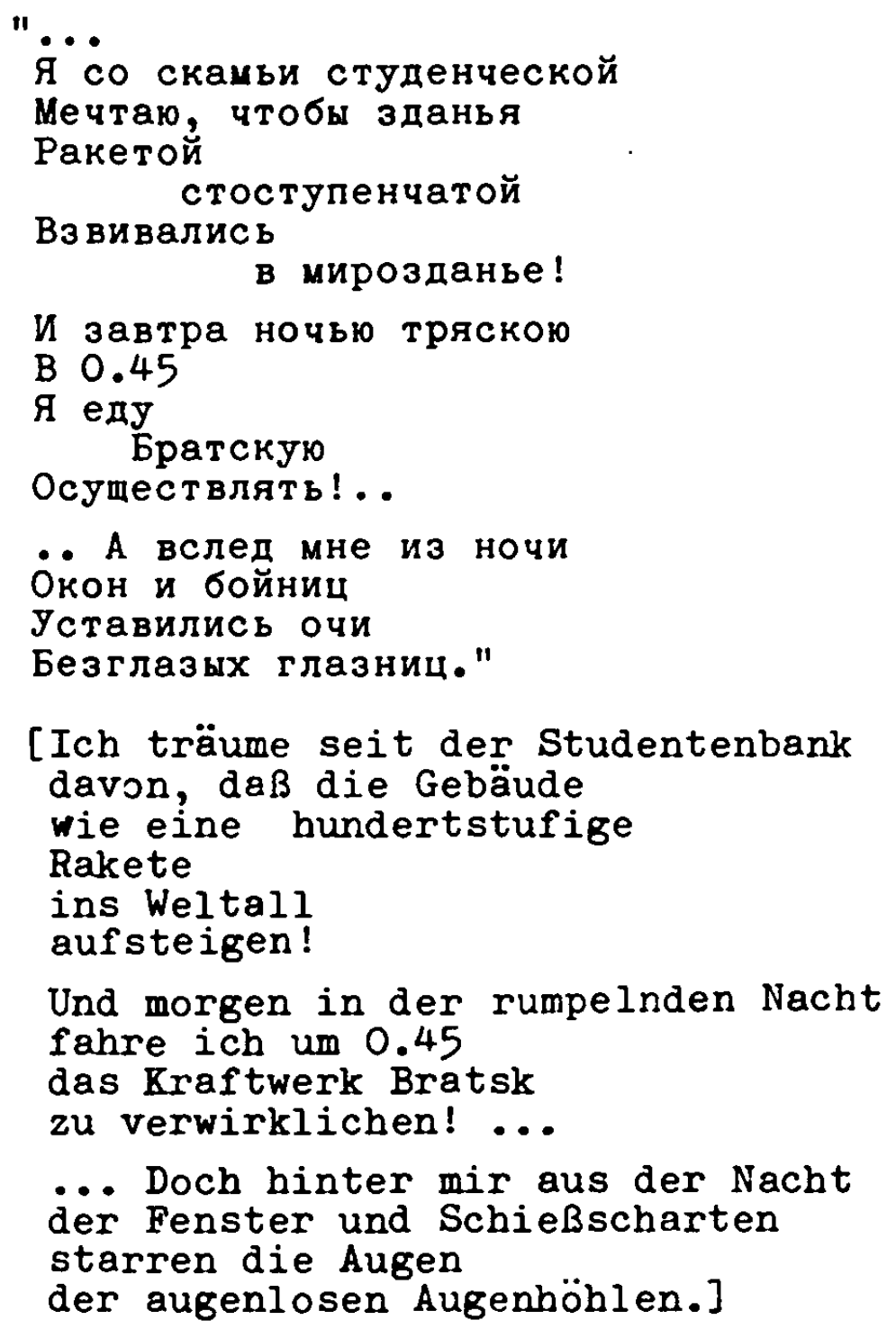

[Ich träume seit der Studentenbank davon, daß die Gebäude wie eine hundertstufige

Und morgen in der rumpelnden Nacht fahre ich um 0.45

das Kraftwerk Bratsk

zu verwirklichen! ...

... Doch hinter mir aus der Nacht

der Fenster und Schießscharten

starren die Augen

der augenlosen Augenhöhlen.] 
Der Gedanke, daß der Künstler zum Opfer ausersehen ist, ein Gedanke, den in Rußland in diesem Jahrhundert am deutlichsten Aleksandr Blok ausgesprochen hat, zieht sich durch das ganze Gedicht. Die erste und zweite Widmung sind Agitationen für die Kunst und "gegen die Barbaren aller Zeiten" und lassen dieses Thema schon anklingen. In der ersten Widmung wird Barma, der Erbauer der Kathedrale, neben Michelangelo und Dante gestellt, werden die Künstler als Tribunen apostrophiert, deren Geschäft der Umsturz ist. Die Kunst geht durch alle Gefängnisse, durch alle Foltern, sie ist der Feuerstein, der gegen die Wände aller "Moabite", wie Voznesenskij metonymisch sagt, schlägt.

Der Text der zweiten "Widmung" ist ein Beispiel für deklamatoriscre Intonation, für agitatorisches Pathos, das den epischen Anfang noch einmal unterbricht:

"Второе посвящение

Москва бурлит, как варево,

Под колокольный звон...

Вам,

Варвары

Bсех времен!

Цари, тираны,

B тиарах яйцевидных,

В пожарищах-сутанах

И С жерлами цилиндров!

Ииперии и кассы

Страхуя от огня,

Вы видели в Пегасе

Троянского коня.

Ball враг - резец и кельма.

И выжженные очи,

Как

Клейма,

Горели среди ночи.

Вас мое слово судит.

Да будет срам,

Да

Будет

Проклятье вам!" 


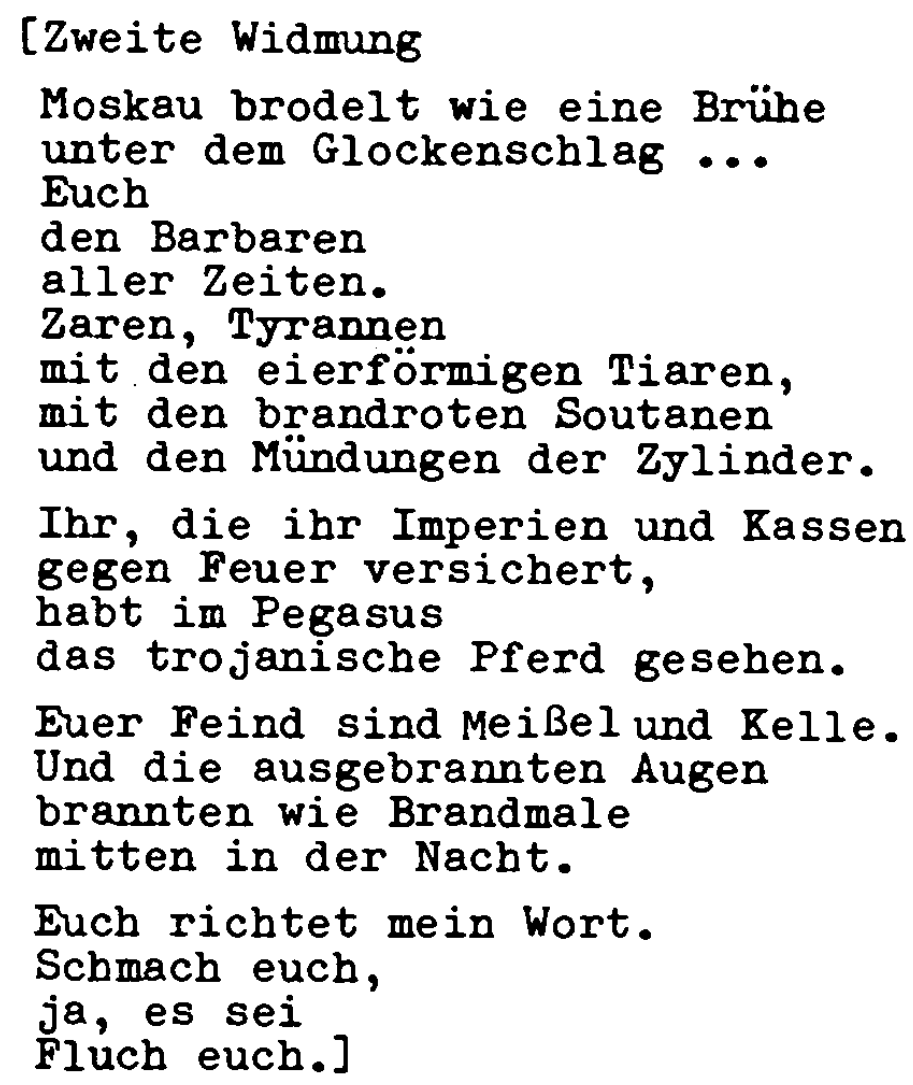

Die einzelnen semantischen Angelpunkte, z.B. die "ausgebrannten Augen", das Werkzeug des Baumeisters, sind und bleiben für den gesamten Text in ihrer Dynamik bedeutungsvoll, und es zeigt sich hier, wie recht $Z$. Mathauser hat, wenn er für das "offene poetische System" feststellt, daß hier grundsätzlich im Gedicht eine intensivere Spannung herrscht, als sie sein "sukzessives Modell" darbietet. Aus den einzelnen Teilelementen entstehen oft Strukturen höherer Ordnung, die für die Erfassung des Gesamtsinns wesentlich sind. Die gegenständliche Welt mit ihrer kausalen und raumzeitlichen Ordnung spielt auch in der epischen Welt der Verserzählung nur eine relative Rolle.

Das erweist sich schon in Voznesenskijs folgendem zyklischen Werk, in den "40 lyrischen Digressionen aus einem Poem", die 1962 unter dem damals schockierenden Titel "Treugol'naja gruša" [Die dreieckige Birne] erschienen. Hier hat Voznesenskij seine Eindrücke aus Amerika verarbeitet, und im Vorwort beschreibt er seine Arbeit wie folgt: Johannes Holthusen-9783954793327 
"Я работаю над большой сюхетной вещью. Она - об 'открытии Америки' - В основу ее легли мои американские впечатления. Но в процессе работы воспоминания, хизнь, пейзахи России и Прибалтики врывались в повествование, отвлекали автора от магистрали сюжета.

'Открывались' совершенно иные предметы."

[Ich arbeite an einer großen Sache mit Sujet. Es geht um die 'Entdeckung' Amerikas. Den Grund bildeten die amerikanischen Eindrücke. Aber im Prozeß der Arbeit drängten sich Erinnerungen, Leben und Landschaften Rußlands und der baltischen Provinzen in die Erzählung ein, sie lenkten den Autor von der Magistrale des Sujets ab.

Es wurden ganz andere Gegenstände 'entdeckt'.]

Noch gespannter sind diese Strukturen dann in Vozneserskijs 1964 erschienener Verserzählung "Oza", deren phantastisches Sujet vergangene und zukünftige Kriege, technische Katastrophen, das Bild der verkehrten Welt, bzw. der "Gegenwelt", aber auch die Welt des Wunders und der Iiebe umspannt.

"Oza" ist auch insofern interessant, als hier der Montagecharakter ganz deutlich hervortritt. Voznesenskijs Fiktion, daB es sich um Blätter aus einem Heft handele, das in dem Nachtkasten eines Hotels in Dubna, dem sowjetischen Atomforscrungszentrum aufgefunden wurde, befreit den Autor von der Notwendigkeit, die lose Folge von Tagebucheintragungen, Notizen, Fragen und Gedichten äuBerlich zu motivieren. Die Grenze der Versdichtung wird hier sogar überschritten durch Passagen in Prosa, die die Tradition der "Gedichte in Prosa" fortsetzen. Abgesehen von syntaktischen Parallelismen, die so etwas wie einen Prosarhythmus erzeugen, sind diese Prosaeinlagen stark mit Vergleichen und Metaphern überladen und tendieren zur Groteske.

"Ты сегодня, I6-го, справляешь день рождения в ресторане 'Берлин' - Зеркало там на потолке.

Из зеркала вниз головой, как сосульки, свисали гости. В центре потолка нехный, как вымя, висел розовый торт С воткнутыми свечами. 
Вокруг него, как лампочки, ввернутые в элегантные черные розетки костюмов, сияли лысины и прически. Лиц не было видно. У одного лысина была маленькая, как дырка на пятке носка. Ее можно было закрасить чернилами.

у другого она была прозрачна, как спелое яблоко, и сквозь нее, как зернышки, просвечивали три мысли (две черные и одна светлая - недозрелая )."

[Du feierst heute, am 16., Geburtstag im Restaurant 'Berlin'.

Der Spiegel hängt dort an der Zimmerdecke.

Aus dem Spiegel hingen die Gäste mit dem Kopf nach unten wie Zapfen. Im Zentrum der Decke hing zärtlich wie ein Euter eine rosafarbene Torte mit aufgesteckten Kerzen.

Um sie herum glänzten wie Glühbirnen eingeschraubt in die eleganten schwarzen Rosetten der Anzüge Glatzen und Frisuren. Die Gesichter waren nicht zu sehen. Einer hatte eine Glatze so klein wie das Loch hinten in einer Socke.

Man konnte es mit Tinte übermalen.

Ein anderer hatte eine durchsichtige Glatze, die einem reifen Apfel glich. Durch sie hindurch schimmerten wie kleine Kerne drei Gedanken (zwei schwarze und ein heller - noch unausgereifter)].

Ahnlich steht es auch mit der Schilderung der phantastischen "Gegenwelt" (den Titel "Antimiry" für ein Gedicht hat Voznesenskij schon in der "Treugol'naja gruša" gebraucht), die in "Oza" auftaucht:

\footnotetext{
"Не узнаю окружающего.

Вещи остались теми же, но частицы их, мигая, изменяли очертания, как лампочки иллюминации на Центральном телеграфе.

Связи остались, но направление их изменилось."

[Ich erkenne die Umgebung nicht mehr. Die Dinge sind dieselben geblieben, aber ihre Teilelemente haben flimmernd andere Umrisse angenommen wie die Glühbirnen der Leuchtschrift am zentralen Telegraphenamt. Die Verbindungen sind geblieben, aber ihre Richtung hat sich geandert.]
}

Mit Umkehrungs- und Spiegeleffekten arbeitet Voznesenskij häufig, um satirische oder groteske Wirkungen zu erzielen. Ich habe schon in meiner kleinen Darstellung der sowjetischen Gegenwartsliteratur 1968 erwähnt, daß die 
"Antiwelten" von Voznesenskij als Anagramme der Wirklichkeit zur BloBlegung und Entlarvung der materialen, logischen und wohl auch gesellschaftlichen Strukturen benutzt werden, eben als Topos der "verkehrten Welt".

Die satirische Funktion ist ganz klar in dem Gedicht "Florentijskie fakely" [Florentiner Fackeln] 1962, in dem Florenz dem Dichter vorkommt wie eine Nachahmung der Pseudorenaissance-Fassaden, die er als Student in der Architekturklasse gezeichnet hat. Da heißt es über die Palazzi:

\footnotetext{
"Я знаю их. Я их калькировал для бань, для стадиона в Кировске, спит Баптистерий, как развитие моих проектов вытрезвителя. Дитя соцреализма грешное, вбегаю в факельные площади, ты - калька с юности, Флоренция!"

[Ich kenne sie. Ich habe sie durchgezeichnet für Badeanstalten, für das Stadion in Kirovsk, दa schläft das Baptisterium, wie die Weiterentwicklung meiner Pläne für eine Ausnüchterungsanstalt. Ein sündiges Kind des Sozrealismus, so laufe ich über die fackelumsäumten Plätze. Du bist ein Abklatsch meiner Jugend, Florenz!]
}

Die Neigung zur Groteske ist auch in den Verserzählungen von Iosif Brodskij sehr groß, und es ist gewiß kein Zufall, daB Brodskij ein Bewunderer des polnischen Dichters Gałczyhski ist. Die erste große Verserzählung "Sestvie" [Festzug/Reigen] ist $196 \mathrm{I}$ entstanden unter dem Eindruck der Lektüre des "Rrysolov" [Rattenfänger] von Marina Cvetaeva. Marina Cvetaeva würde übrigens in der Genealogie der modernen russischen Verserzählung ein wichter Platz gehören, gerade in der ironisch-satirischen Richtung. Die "Poema konca"entstand bereits im Jahre 1924, und der Rattenfänger ("Krysolov, Liričeskaja satira") in Paris 1925. Brodskijs "Sestvie" bietet den Auftritt einer Reihe von Typen der Weltliteratur, die 
in Romanzen ihre Rollen aufsagen und die vom Dichter dann besonders kommentiert werden. Es treten nacheinander auf: Harlekin und Colombine, der Dichter, Don Quijote, der Lügner mit einer Ballade und einer Romanze, der müde Großstädter, der Geiger, der König mit Ballade und Romanze, der Dieb, Fürst Myškin aus Dostoevskijs "Idiot", ein Ehrenmann nebst Chor, die Klage, der Händler, der Glückspilz, die Liebenden, der Rattenfänger nebst Chor, Prinz Hamlet und als letzter der Teufel. Das Schlußgedicht zeigt Brodskij als den ironischen Schauspieldirektor, der seinen Festzug drei Monate lang vorüberziehen ließ und nun auf der Schreibmaschine die letzten Worte tippt:

"Стучит машинка. Вот и все, дружок.
В окно летит ноябрский снежок,
Фонарь, висячй на углу кадит,
вечерней слухбы колокол гудит,
таги моих прохожих замело.
Стучит машинка. Шествие прошло."

[Die Maschine klappert. Das ist alles, Freund. Ins Fenster fliegt der Novemberschnee, die Laterne, die an der Ecke hängt, verbreitet Weihrauch die Glocke des Abendgottesdienstes tönt, die Schritte meiner Passanten sind verweht. Die Maschine klappert. Der Reigen ist vorbei. (September-Oktober-November 1961. Leningrad).]

Die weiteren parodistischen und satirischen Verserzählungen Brodskijs würden sicherlich eine eigene Darstellung verdienen: Eine makkaronische Deutschland-Satire und FaustParodie unter dem Titel "Dva časa v rezervuare" [Zwei Stunden im Reservoir], 1965, und "Gorbunov i Gorčakov" [Gorbunov und Gorčakov], 1965-68, ein Dialog in Versen. In dem letzten Poem wird gelegentlich die Sprache selbst parodiert, werden die Möglichkeiten des Ausdrucks ad absurdum geführt. Der fünfte Gesang "Pesnja $v$ tret'em lice" [Lied in der dritten Person] könnte an bestimmte Sequenzen von Peter Handke erinnern: 


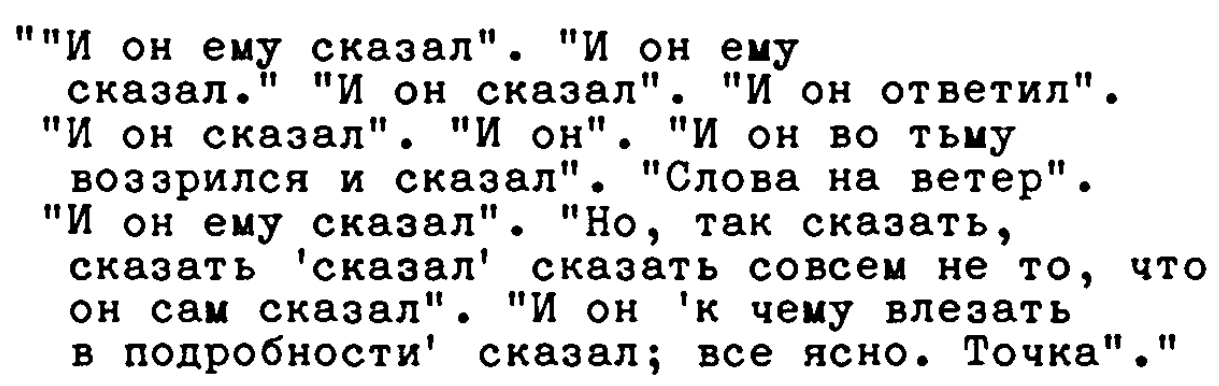

["Und er sagte ihm". "Und er sagte ihm". "Und er sagte". "Und er antwortete". "Und er sagte". "Und er". "Und er biickte in das Dunkel und sagte". "Worte in den Wind". "Und er sagte ihm". "Aber, sozusagen, besagt 'er sagte' ganz und gar nicht das, was er selbst sagte". "Und er sagte 'wozu sich in Einzelheiten verlieren'; alles ist klar. Punktum."]

Als äuBerst produktive Gattung erweist sich auch die Ballade, die sich teilweise (etwa bei Vinokurov, Okudžava, Evtušenko) in Richtung auf Bänkelsang, Moritat, heroisch-komische und burleske Stilisierung entwickelt, teilweise aber auch, wie besonders bei Voznesenskij, in Richtung auf die tragische oder tragikomische Groteske. Die Geschichte der nodernen russischen Ballade ist noch nicht geschrieben, aber im großen und ganzen wïrde sich hier die Richtigkeit des Ansatzes von Karl Riha erweisen, der in seinem Buch "Moritat, Song, Bänkelsang. Zur Geschichte der modernen Ballade" (1965) den Typus der heutigen Ballade mit den revolutionären Neuerungen bei Arno Holz, Christian Morgenstern, Frank Wedekind und Bert Brecht in Zusammenhang bringt. Mit der episch-feierlichen Gattung der konservativen und historisierenden Ballade hat die neue russische Ballade wenig zu tun.

Ein durchgehender Zug der zeitgenössischen russischen Lyrik ist, daB sich der Dichter selbst nicht allzu ernst nimmt. Das kann man schon an der Thematik ablesen, die mit dem eigenen Versagen, dem "Nicht-mehr-Schreiben-Können" zusammenhängt. Ir Andrej Voznesenskijs neuestem Band "Ten' zvuka" [Der Schatten des Lautes], 1970, ist die ironische Elegie abgedruckt, 
die der eigenen Krise gewidmet ist: "Ironičeskaja èlegija, rodivšajasja $v$ ves'ma skorbnye minuty, kogda NE PISETSJA" [Ironische Elegie, die in jenen überaus verdrießlichen Minuten entstand, wenn man nicht schreiben kann]:

"Не деградируете вы -

Я деградирую.

Был крепок стих, как рафинад.

Свистал хоккейным бомбардиром.

Я разучился рифмовать.

Не получается.

Чухая птица издали

простонет перелетным горем.

Умеют хором журавли.

Но лебедь не умеет хором."

[Wenn ihr nicht degradiert, -

ich degradiere.

Mein Vers war stark wie Raffinade.

Er pfiff wie ein Hockeyangriff.

Ich habe verlernt zu reimen.

Es klappt nicht mehr.

Ein fremder Vogel ächzt von weitem unter dem Zugvogelgram.

Es verstehen sich auf einen Chor die Kraniche. Doch ein Schwan taugt nichts im Chor.]

Pathos und Rhetorik sind der heutigen Lyrik durchaus nicht fremd, aber auch die sogenannte Bekenntnislyrik verzichtet nicht auf eine starke und sympathische Beimischung von Selbstironie. Als Beispiel für moderne Bekenntnislyrik, die wiederum stärker dem reflexiv-didaktischen Pol als dem emotionalen Pol zugeordnet ist, soll hier ein Gedicht von Evgenij Vinokurov stehen, das in seinem Band "Zrelišča" [Schauspiel], 1968, enthalten ist. Das Gedicht behandelt die Frage nach dem Grad der Aufrichtigkeit, die für den Menschen zuträglich und notwendig ist, wenn er die lüge nur noch erbrechen kann wie faulen Fisch.

Anstatt in Ehrlichkeitspathos zu verfallen, vergleicht sich das lyrische Subjekt in diesem Gedicht von Vinokurov mit Don Quijote, der gegen Windmühlen ficht: die Suche nach Auf- 
richtigkeit wird zum komischen, über das Ziel hinausschießenden, kindlichen und am Ende nutzlosen Unterfangen:

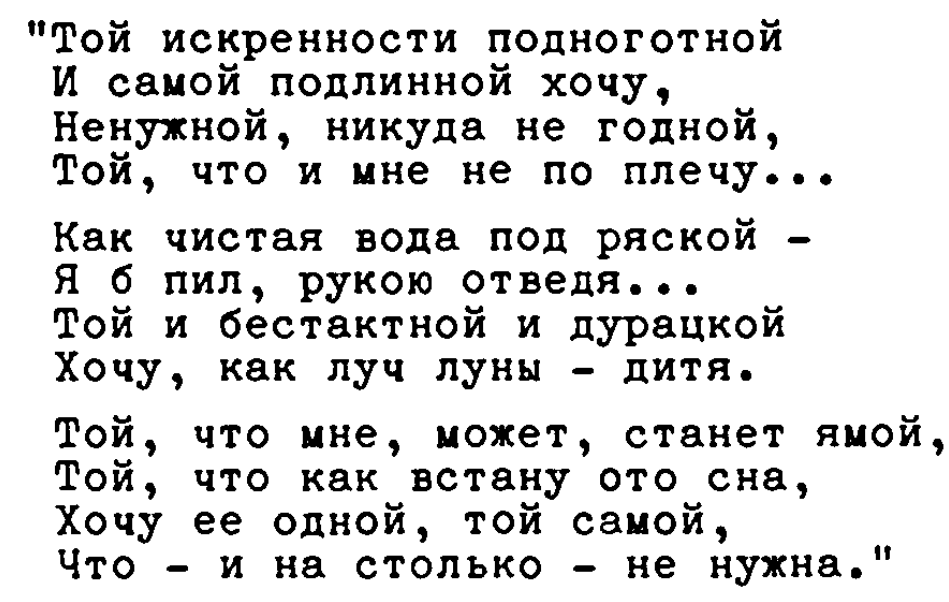

[Nach jener Aufrichtigkeit noch 'unter dem Fingernagel', nach der.ganz authentischen suche ich, die so nötig, nirgends passend ist, nach der, die auch mir uber die Krafte geht.

Sie würde ich trinken wie reines Wasser unter dem Entengrün, das man mit der Hand wegschiebt ... Nach der, die taktlos und närrisch ist, verlange ich, wie das Kind nach derr Mondilicht. Nach der, die mir, vielleicht, eine Grube gräbt, nach der allein ich verlange, wenn ich vom Schlaf aufsteh gerade nach der, die so absolut nicht gebraucht wird.]

Das lyrische Subjekt gibt sich unzeremoniell, ohne feierlichen und auch ohne tierischen Ernst, oft eigenwillig und verspielt, oft ironisch, bisweilen sarkastisch.

Die Ausstattung des Bandes "Zrelišča" weist auf einen Zug, der mir für die russische Lyrik der 60er Jahre besonders charakteristisch zu sein scheint. Die Semantik der lyrischen Sprache korrespondiert nickt selten mit konkreten Figuren, mit geometrischen Vorstellungen, mit Bilderbogen, mit Werken der Architektur und der Malerei. Bei Voznesenskij hat das den Hintergrund, daß er selbst sich mit Architektur und bildender Kunst beruflich beschäftigt hat, und so gibt es bei ihm eine Fülle von thematischen und semantischen Berührungspurkten mit der Baukunst und der Malerei. Ich meine damit nicht die Werkstruk- 
turen als solche, die man gern metaphorisch mit geometrischen oder figürlichen Darstellungen vergleicht, sondern auf der semantischen Ebene die Wortbedeutungen und in der gegenständlichen Schicht die emblematischen Entsprechungen. Wir haben mit den "Florentiner Fackeln" schon ein Beispiel für die unmittelbare gegenständliche Beziehung zur Architektur vorgeführt. Man könnte das Poem "Mastera" hier wieder anführen, die "Ballada raboty" [Ballade der Arbeit], in der sich das Schicksal von Peter dem Großen mit dem Gedanken an die Bilder von Peter Rubens verknüpft, man muß an die Gedichte aus Amerika denken, die "Treugol'naja gruša", die als Bild für eine bestimmte Form von Lampen in der New Yorker Untergrundbahn steht, an das wirklich eindrucksvolle Gedicht "Nočnoj aèroport v N'ju Jorke" [Nächtlicher Flughafen in New York], das von Voznesenskij selbst als "architektonische Digression" bezeichnet wird. Um wieder auf Vinokurov zurückzukommen: die verschiedenen Illustrationen $z u$ den Gedichten, in denen in reichem Maß von den russischen Volksbilderbogen, den "lubočnje kartinki" Gebrauch gemacht wird, beziehen sich in der Regel auf den emblematischen Gehalt der sie begleitenden Gedichte, so daß sich die Beziehung zwischen Gedicht und Abbildung als Beziehung Werk-Kommentar darstellt.

Da Vinokurov eigentlich ein rationalistischer Dichter ist, nähern sich seine Gedichte manchmal der emblematischen Poesie. So etwa in dem Zyklus "Poetty" [Dichter] das 13. Gedicht:

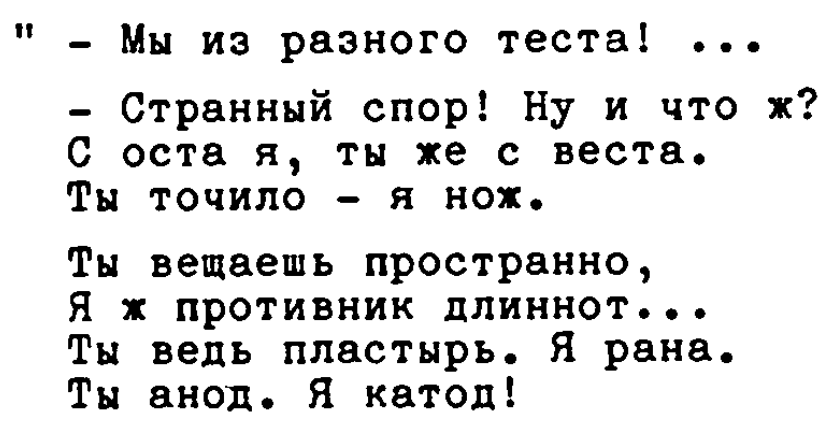


Мы враги, но гораздо

Нас мудрей этот свет, В нем ведь, кроме контраста, Ничего-то и нет..."

[ - Wir sind aus verschiedenem Teig!

- Merkwürdiger Streit! Was soll's?

Ich bin aus dem Osten, du aus dem Westen.

Du der Schleifstein, ich das Messer.

Du redest ausführlich,

ich aber bin Feind der Weitschweifigkeit.

Du bist das Pflaster, ich die Wunde.

Du die Anode, ich die Kathode!

Wir sind Feinde. Doch viel weiser

als wir ist diese Welt.

In ihr gibt es nämlich außer dem Kontrast gar nichts weiter.]

Interessant ist, wie bei Vinokurov der Intellekt eine ausgesprochene Skepsis gegenüber der Natur entwickelt. Ein Gedicht beginnt mit der Zeile: "Ja malo otdaju vnimanija prirode ..." [Ich gebe auf die Natur wenig acht ...], und man kann wohl sagen, daß seit Pasternak und Zabolockij die sogenannte Naturlyrik ihren Vorrang fast völlig eingebüßt hat und heute wahrscheinlich am häufigsten als triviale Gattung vorkommt.

Programmatisch ist sicherlich Vinokurovs Gedicht über die Trockenheit, das die antisentimentalische und asketische Haltung des Dichters besonders betont:

\footnotetext{
"Ничто на свете пусть не окропит Земли, звездой растрескавшейся в зное... Врамается в орбитах и скрипит Mое сухое яблоко глазное! Нисходит часто сухость неспроста. Подчас такая сухота в гортани, Что вдруг как бы немеет полость рта И судорога при глотаньи... Будь просто сух, как отлетевший сук, Как снег бывает сух при стуже, Как протокол ночной, будь только сух, И с кахдым днем будь суше, суше, суше..."
} 
[Es soll nichts auf der Welt die Erde besprengen, den Stern, der in der Hitze rissig wurde ... In den Umlaufbahnen dreht sich knarrend mein trockener Augapfel!

Oft kommt nicht ohne Grund eine Dürre herab, zuweilen hat man eine solche Trockenheit im Mund, daß einem plötzlich gleichsam die Mundhöhle taub wird und sich die Kehle verkrampft .... Sei einfach trocken wie ein abgerissener Zweig,

wie der Schnee trocken wird bei Frost, wie ein Nachtprotokoll so trocken solist du werden und mit jedem Tag trockner, trockner, trockner.]

Mensch und Natur stehen sich auch fremd gegenüber in dem kleinen Gedicht "Vdochnovenie" [Eingebung], in dem die Inspiration als Eidechse auftritt, die der Dichter nicht fassen kann, er behält nur den Zipfel, ihren abgebrochenen Schwanz in der Hand zurück. "Net, ne gordoe paren'e" [Nein, kein stolzes Schweben] - so lautet der erste Vers dieses Gedichtes, das wiederum von der Nüchternheit der heutigen Vorstellung vom Schöpfertum Zeugnis ablegt.

Zum SchluB möchte ich noch auf die Frage nach der Rolle des Experimentes in der neueren sowjetrussischen Lyrik eingehen. Wenn man sich klar macht, daß Experiment und Avantgarde in der russischen Lyrik bereits zwischen 1910 und 1920 ihren vorläufigen Höhepunkt gefunden haben, besonders natürlich im Werk der Futuristen, dann wird man von der heutigen Generation vielleicht eher enttäuscht sein, daß sie auf dem Gebiet der "konkreten Poesie" und anderer experimenteller Richtungen verhältnismäßig wenig anzubieten hat. Diese Feststellung mag insofern voreilig sein, als die illegalen Drucke, die es sehr wohl gibt, hier zu anderen Befunden führen könnten.

Abgesehen von diesem schwer zu überblickenden illegalen Markt bleiben jedoch die Experimente eher harmlos und reproduzieren teilweise das, was Dichter wie Chlebnikov, Majakovskij und später Sel'vinskij bereits kanonisiert hatten. Am belieb- 
testen ist wohl die Sprachgroteske, wie sie Voznesenskij in seinem Gedicht "Gripp 'Gonkong' - 69" [Hongkong-Grippe 69] verwendet:

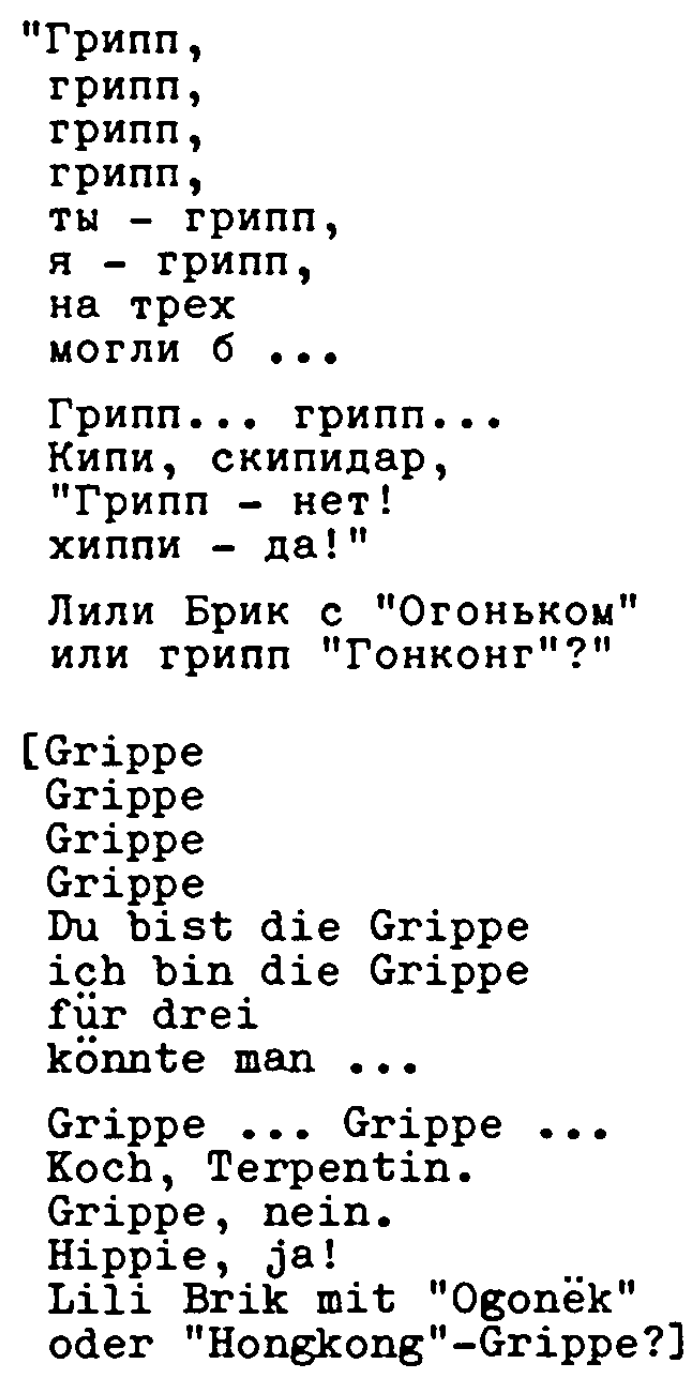

Eine lautmalende und quasi bildhafte Funktion hat die Sprahgroteske in dem ebenfalls neuen Gedicht "Boj petuchov" [Hahrenkampf], das das Bild von den kämpfenden Hähnen verknüfft mit dem Bild, in dem die Köchin den Hahn schlachtet:

\footnotetext{
"Петухи! Петухи! Потуши! Потуши! Cпор шпор, ку-ка-рехнулись! Урарь! $\mathrm{xy}-\mathrm{xa} \ldots$ Кухарка харакири $\operatorname{xpp}$$$
\text { -.. }
$$$$
\mathrm{xp}-\mathrm{pp}
$$

Какое бешеное счастье, хрипя воронкой горловой, под улюлюканье промчаться с оторванною головой!" 
[Ḧ̈̈hne!

Hähne!

Lösch!

Lösch!

Der Kampf der Sporen.

$\mathrm{Ki}-k e-r i$, sie sind verrückt!

Lauf Sturm!

Hu-ha ...

Köchin

Harakiri

chrr

-.・

chr-rr

Welch ein verrücktes Glück.

aus dem Kehlkopftrichter rochelnd

unter Gejohl vorbeizufliegen

mit abgerissenem Kopf!]

Dieses letzte Textbeispiel hat Voznesenskij aber auch selbst in der Art der "konkreten Poesie" aufgezeichnet in Gestalt eines seine Federn sträubenden Kampfhahnes, dessen abgerissener Kopf auf der gegenüberliegenden Seite erscheint:
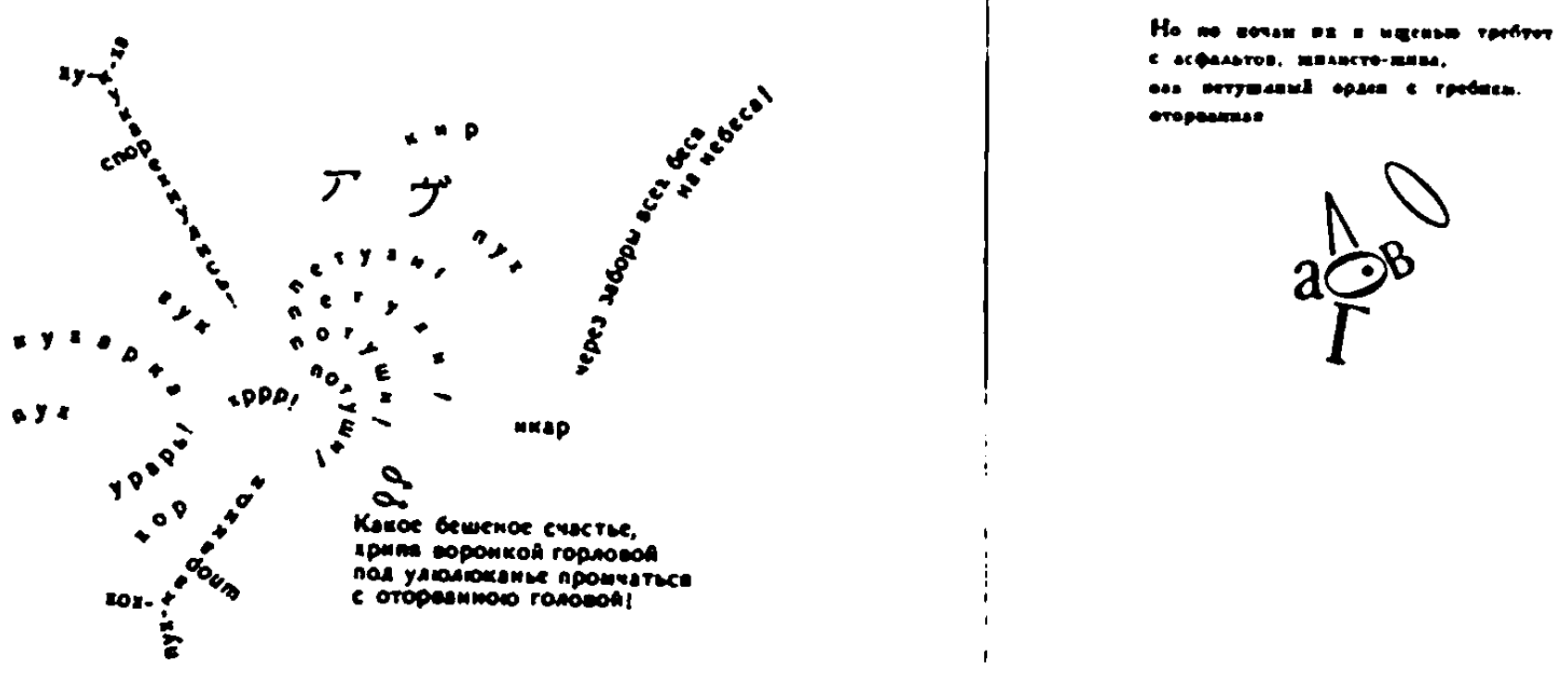
Die Sprachlaute werden hier über die Buchstaben zum anschaulichen Material, das Voznesenskij selbst "Opyty izobrazitel'noj poèzii". [Versuche der darstellenden Poesie] (abgekürzt "Izopy") nennt. Als Einleitung zu diesem Abschnitt in "Ten' zvuka" schreibt Voznesenskij dazu:

"В противовес эстрадной, чтецкой поэзии (ЧП) я попытался - чем черт не шутит! - написать 'только для глаз'. Если ЧП вбирает в себя черты актерства и роднится с музыкой, то изопы соединяют слова и графику, становятся структурами."

[Als Gegengewicht zur podiumsgebundenen, rezitatorischen Poesie (CP) habe ich versucht - womit der Teufel nicht spielt!-,'nur für die Augen' zu schreiben. Wenn die rezitatorische Poesie in sich Züge der Schauspielerei aufnimmt und mit der Musik verwandt ist, so verbinden 'Izopy' Wörter und Graphik, werden zu Strukturen.]

Interessant ist, daß Voznesenskij dann weiter versucht, die 'konkrete" Poesie aus der russischen Tradition zu erklären, aus den altrussischen Handschriften, aus den Holzschnittbilderbogen (lubki) und aus der zweifarbig gedruckten "Arifmetika" von Magnickij.

Auch auf die alten Akrosticha geht Voznesenskij ein, wo graphisch bestimmte Buchstaben hervorgehoben sind. Weiter bezieht sich Voznesenskij auf Nodier, dessen Leitern von Worten Puškin bereits bewunderte, auf van Goghs farbige Namenszüge, auf Mallarmé, Majakovskij, Chlebnikov, Kirsanov, vor allem aber auf die Kalligramme Apollinaires. Man kann also sagen, daB die Vorstufen zur konkreten Poesie jetzt auch in RuBland als bedeutungsvoll anerkannt sind. Voznesenskij geht nämlich auch darauf ein, daß durch Kino und Fernsehen der Informationsfluß ungeheuer vergrößert worden ist und damit überhaupt das Feld der optischen Wahrnehmungen. 
I it e raturang a b e n

B a $r t$ a, Johann: Zur Theorie der lyrischen Dichtung. In: Zagadnienia rodzajów literackich. Tom IV, Zesyt 1. Eódz 1961 .

B $1 \circ \mathrm{k}$, Aleksandr: Zapisnye knižki 1901-1920. Moskva 1965.

B r o d s k i j, Iosif: Ostanovka $v$ pustyne. Stichotvorenija i poèmy. New York 1970.

$G$ a $s$ p a r o v, M.: Taktovik v russkom stichosloženii $X X$. veka. In: Voprosy jazykoznanija, 1968, 5 .

$\mathrm{H} \circ \mathrm{l}$ t $\mathrm{h}$ u $s$ e $\mathrm{n}$, Johannes: Russische Gegenwartsliteratur II. 1941-1967. Prosa und Lyrik. Bern u. München 1968.

$\mathrm{K}$ a $\mathrm{n}$ t e m $\mathrm{i}$, Antioch: Sobranie stichotvorenij. BP (b. ser.). Leningrad 1956.

L o $t$ m a n, Jurij: Lekcii po struktural'noj poetike. (Trudy po znakovym sistemam, I.)Tartu 1964.

M a $j$ a $k \circ \mathrm{v} s \mathrm{k} j$, Vladimir: Sobranie sočinenij $\mathrm{v}$ vos'mi tomach, III. Moskva 1968.

M a $t$ h a u s e r, Zdeněk: Spirála poezie. Ruské básnictví od roku 1945 do soucasnosti. Praha 1967.

O k u d ž a v a, Bulat: Veselyj..barabanščik. Moskva 1964.

R i h a, Karl: Moritat, Song. Bänkelsang. Zur Geschichte der modernen Ballade. Gottingen 1965.

V i n o k u r o v, Evgenij: Zrelisča. Stichi. Moskva 1968.

$\mathrm{V} \circ \mathrm{z} \mathrm{n}$ e $\mathrm{s}$ e $\mathrm{s} \mathrm{k} i \mathrm{j}$, Andrej: Treugol'naja gruša. 40 liričeskich otstuplenij iz poèmy. Moskva 1962.

$V \circ z n$ e $s$ e $s k i j$, Andrej: Achillesovo serdce. Stichi. Moskva 1966.

V 
Solženicyns Erzählkunst

Im Jahr 1846 veröffentlichte Gogol' zum Entsetzen seiner demokratischen Verehrer ein Buch mit dem so harmlosen Titel "Vybrannye mesta iz perepiski s druz'jami" [Ausgewählte Stellen aus einem Briefwechsel mit Freunden]. In diesem Werk zeigte sich Gogol' zum ersten Mal als strenger Moralist in der Absicht, Rußland und zugleich die Rolle seines eigenen Werkes neu zu bestimmen. In dem lesenswerten Brief mit dem Titel "Svetloe voskreser.'e" [Ostersonntag] unterscheidet Gogol' hier scharf zwischen dem Blick auf die gesamte Menschheit, der Liebe zur gesamten Menschheit und dem Blick auf den einzelnen Nächsten, der Liebe, die dem Bruder gilt. Das Umarmen der Menschheit, so urteilt Gogol', ist ein Zeichen für den Stolz des Intellektes, und erst der Osterkuß auf der Wange des Nächsten stellt den Menschen in die Gemeinde der Christen.

Uber die Schwierigkeit, den Nächsten zu lieben, zitiert Gogol' ironisch die Stimme einer Amtsperson:

"Я не могу обнять этого человека: он мерзок, он подл пушой, он залятнал себя бесчестнейшим поступком; я не пущу этого человека паже в переднюю свою; я паже не хочу дышать одним воздухом с ним..."

[Ich kann diesen Menschen nicht umarmen: er ist ekelhaft, seine Seele ist niederträchtig, er hat sich durch absolut ehrloses Verhalten beschmutzt. Diesen Menschen kann ich nicht einmal in teein Vorzimmer lassen, ich mag nicht einmal die gleiche Luft mit inm atmen ....]

(Vortrag gehalten am 7.11.1972 in der Bayerischen Akademie der Schönen Künste, München) 
In der Besserung und Veränderung der Menschheit sieht Gogol' den zentralen Gedanken des 19. Jahrhunderts, aber wer diesen Gedanken nur abstrakt denkt, ist für ihn nur ein Illusionist:

"Все человечество готов он обнять, как брата, а
брата не обнимет. Отделись от этого человечества,
которому он готовит такое великодушное объятье,
один человек, его оскорбившй, которому повеле-
вает Христос в ту же минуту простить, - он уже не
обнимет его. А достанется его объятие только тем,
которые ничем не оскорбили его, скоторыми не имел
он случая столкнуться, которых он никогда не знал
и даже не видал в глаза. Вот какого рода объятье
всему человечеству дает человек нынешнего века..."

[Die ganze Menschheit ist er bereit zu umarmen wie einen Bruder, aber den Bruder will er nicht umarmen. Sobald aber aus dieser Menschheit, der er eine so großmütige Umarmung zugedacht hat, einer heraustritt, der ihn gekränkt hat, dann ist er schon nicht mehr bereit den zu umarmen, dem zu verzeihen Christus in diesem Augenblick gebietet. Und seine Umarmung ist nur für diejenigen da, die ihn durch gar nichts gekränkt haben, mit denen er gar keine Gelegenheit gehabt hat zusammenzustoßen, die er nie kennengelernt hat und sogar nicht einmal persönlich gesehen hat. Das ist die Art, wie der Mensch dieses Jahrhunderts die Menschheit umarmt....]

Wenn Solženicyn, um den es uns in Wirklichkeit zu tun ist, in seiner nicht gehaltenen Dankesrede für den Nobelpreis nach einem einheitlichen Beurteilungssystem für die täglichen Vorgänge in der sichtbaren Nähe und die Vorgänge in der Ferne ruft, dann meint er wie Gogol' die tberwindung dieser Kluft zwischen dem abstrakten und dem konkreten Gegenüber, meint er die faktische Unteilbarkeit des moralischen Standpunktes.

Wenn man sich mit Solženicyn näher beschäftigt, dann wird einem zwar deutlich, daß man den Autor, wie es der verärgerte Belinskij seinerzeit mit Gogol' gemacht hat, nach den Kriterien eines bestimmten ideologischen Gegensatzes in die Abseitsposition drängen kann, daß aber dadurch sein literari- 
sches werk nichts an Eindruckskraft und auch nichts an Authentizität verliert. Solženicyn ist nicht Theoretiker der Gesellschaft, sondern eines ihrer unveräußerlichen Glieder, und, unter den zur Zeit waltenden Umständen, faktisch ihr Opfer.

Solženicyn beschreibt und analysiert das praktische Leben zunächst einmal im Mikromaßstab. Seine Probleme sind, wie man sich mit dem Nächsten verträgt, wer und was der Nächste ist, wie im Gefängnis oder im Krankensaal so etwas wie Freundschaft und Liebe möglich sind, was Krieg und Zwist in der nächsten Nähe bedeuten. Solženicyn nimmt den jeweils Nächsten ernst, setzt ihn strengen Erprobungen aus und spart auch nicht mit Kritik. Dabei ist der Dichter aber wieder vor einem Mißverständnis in Schutz zu nehmen. Seine tberzeugungen erscheinen gerade in den kritischen Ausblicken auf den Menschen in unverschlüsselter Klarheit. Seine Bücher enthalten einen Appell, aber einen Appell, der keiner allegorischen Auslegung bedarf. Obwohl es beim Erzählen selbstverständlich um fiktive Sachverhalte geht, um Sachverhalte, die nur als Wirklichkeit e r s c b e i n e n - das ist nach Käte Hamburger die "Logik der Dichtung" -, bleibt Solženicyns Erzählhaltung im Grunde die Haltung des Faktographen. Die Krebsstation ist wirklich eine Krebsstation, selbst mit allen sich anbietenden Analogien zu bösartigen gesellschaftlichen Deformationen. Solženicyn denkt als Naturwissenschaftler viel zu klar und zu scharf, als daß er neben der strengen Kausalität roch eine symbolische Geschichtsphilosophie oder einen eigenen Mythos brauchte, um die schwierige Lage des Menschen in dieser Welt zu begründen.

Nun vollzieht sich aber das Erzählen, das Solženicyn als eigene Kunst handhabt, im Medium der Sprache. Das Verstehen 
des nichtrussischen Lesers ist hier im häufigsten Fall auf die vermittelnde Brücke der Ubersetzung angewiesen. Es liegt mir fern, einzelne tbersetzungen hier miteinander vergleichen zu wollen, aber die Frage sei doch aufgeworfen, welche Besonderheiten der russischen Sprache und der Sprache Solženicyns dem tbersetzer Probleme aufgeben.

Zunächst wäre da an die besondere Schichtung der russischen Literatursprache $z u$ erinnern, die eine volkstümliche (ursprünglich vorwiegend bäuerliche) Sprachschicht mit eigener Syntax ebenso kennt wie eine Erzählsprache, die eigentlich für den mündichen Vortrag stilisiert ist und von den Russen als "Skaz" bezeichnet wird. Daneben können charakteristische Eigenschaften anderer Sprachen wie z.B. des Ukrainischen im Dialog und sogar im BewuBtseinsbericht verwendet werden, um, wie in diesem Fall, südliches Lokalkolorit einzuführen. Von diesen ukrainischen Einschüben macht Solženicyn etwa in "August 14" (Avgust četyrnadcatogo) ganz bewußt Gebrauch. Hinzu kommt als Standessprache ganz neuer Prägung das bürokratische Parteirussisch sowie die besondere Sprache der Häftlinge, der politischen Häftlinge und der Strafhäftlinge. Alle diese sprachlichen Mittel werden von Solženicyn auch als Mittel der Komposition eingesetzt, und sie gilt es dann in der Ubersetzung zu erkennen, was nicht immer leicht gelingen wird. Daß hier auch die ästhetische Rezeption eine Rolle spielt, wird am schnellsten klar, wenn man Solženicyns eigene Aussagen über die russische Literatursprache betrachtet. In einer offenen Diskussion mit dem inzwischen verstorbenen Philologen Viktor Vinogradov forderte Solženicyn 1965 in den Spalten der "Literaturzeitung" (Literaturnaja gazeta) die genauere Beachtung der "elastischen russischen Wortfolge", die 
schöpferische Beschäftigung mit dem ungeheuren Wortschatz des Russischen, die Bereicherung der durch Eingriffe der Obrigkeit unansehnlich gewordenen modernen Schriftsprache durch die Lebenskraft der russischen Volkssprichwörter, die genaue Schulung an der gesprochenen mündichen Sprache, die Ersetzung des Häßlichen durch das Schöne, des Langen durch das Kurze, des Verschleierten durch das Klare.

Diesem Rezept folgt der Erzähler Solženicyn sehr treu, und die Dialektik der Sprachentwicklung in der Zeit des Stalinismus ist das geheime Thema seines Romans "Im ersten Kreis" (V kruge pervom), der polemisch, parodistisch und ironisch durchgehend Sprachkritik übt. Semantische Ironie tritt z.B. in den Worten des Parteisekretärs Stepanov zutage, der darüber klagt, daß ... "все это сделано на бумаге (потому что - только на словесных уверениях), а не на деле (то есть не на бумаге, не в виде протоколов)." [... alles ja nur auf dem Papier erledigt sei (weil nur in mündlichen Versicherungen), aber nicht in Wirklichkeit (das heiBt nicht auf Papier, nicht in Gestalt von Protokollen)]. Die semantische Spannung erhebt hier das Papier zur Wirklichkeit und degradiert die wirklich gesprochene Rede zum "Papier".

Offene Gesellschaftskritik wird sicherlich am stärksten ebenfalls im "Ersten Kreis" geübt. Wir dürfen hier Georg Lukács zum Kronzeugen wählen, der in diesem Roman wichtige Formen der Entmenschlichung, der Entfremdung des Menschen von sich selbst - und zwar in einer scheinbar sozialistischen Gesellschaft aufgedeckt fand. Insofern dürfte die Betroffenheit durch Solženicyn sehr allgemein sein, und die Reaktion der für die gesellschaftliche Entwicklung in Solženicyns Heimat Verantwortlichen zeigt das ja auch sehr kraß. Wir wollen hier aber nicht 
ausgetretene Wege gehen und etwa näher die delikate gesellschaftliche Rolle des Schriftstellers in RuBland untersuchen. Zu diesem Thema hat Solženicyn selbst sehr viel tberzeugendes gesagt und auch getan.

Mit einem Problem, auf das gerade der nach Identifikation suchende Leser von Anfang an zu reagieren gezwungen ist, möchte ich der Betrachtung der Erzählkunst näher kommen. Es handelt sich um die leidigen russischen Personennamen, um die so verschiedenen Benennungen der Menschen. Damit steht in engem Zusammenhang der ungewöhnliche Reichtum an Haupt- und Nebenpersonen, mit dem wir es bei Solženicyn zu tun haben.

Das System der Benennungen ist bei Solženicyn besonders gut zu durchschauen. Die vier Varianten: 1. Vorname, 2. affektiver Name (d.h. 2.B. ein Kosename), 3. Vor- und Vatersname, 4. schließlich der Nachname treten nicht willkürlich, sondern in perspektivischer Ordnung auf. Solženicyns stark engagierte Perspektive läßt z.B. bei Kostoglotov in der "Krebsstation"

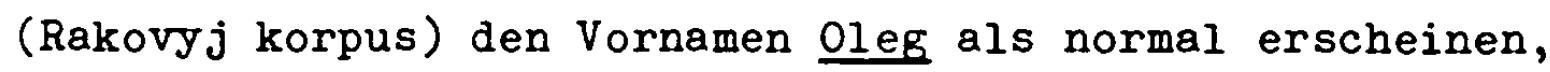
ganz besonders nachdem er in nähere Beziehung zur Krankenschwester Zoja getreten ist. Welcher Leser aber erinnert sich schon an den Vatersnamen, den Zoja einmal in seiner Karteikarte findet und den sie dann in ihrer Anrede gebraucht: Oleg Filimonovič. Kostoglotov kontert denn auch gleich: "Net už! kak načali, požalujsta: Oleg!" [Nicht doch! Bleiben Sie nur bitte bei Oleg!] Der Vatersname, um dessentwillen auch die Russen ihr Gedächtnis besonders trainiert halten müssen, bedeutet zuvorkommende Anrede unter zivilisierten Menschen, Höflichkeit dem Ubergeordneten gegenüber oder einfach automatisierte Routine. Daß der Häftling Neržin von dem Oberstingenieur Jakonov im "Ersten Kreis" als "Gleb Vikent'ič" angeredet wird, bedeutet 
bewuBte Anerkennung des gleichen intellektuellen Niveaus und zugleich eine Art Auszeichnung durch den Vorgesetzten:

"Обращение по имени-отчеству означало любезность
и доброжелательство, одновременно не стоя инте-
нер-полковнику труда, так как под стеклом у него
лежал перечень всех заключенных сих именами-
отчествами (кто не знал этого обстоятельства, по-
рахался памяти Яконова)."

[Die Anrede mit dem Vor- und Vatersnamen drückte Liebenswürdigkeit und Wohlwollen aus, sie kostete gleichzeitig den Oberstingenieur keine Mühe, denn unter dem Glas vor ihm lag die Liste aller Häftlinge mit ihren Vor- und Vatersnamen (wem dieser Umstand nicht bekannt war, dem konnte Jakonovs Gedächtnis imponieren].

Vor und Vatersname sind zunächst nur im persönlichen Verkehr eine Ehrerbietungsformel, so z.B. wenn der einheimische Leiter der Krebsstation nur in dieser Perspektive auftaucht: "Nizamutdin Bachramovič" - der Name ist zugleich untrügliches Zeichen für seine asiatische Herkunft. Vergleichbar ist auch noch die etwas ironische Perspektive, in der jene Krankenschwester in Sicht kommt, die, wie es heißt, "solider als mancke Arrztin aussah", sie führt den würdevollen Namen Olympiada Vladislavovna. Im unpersönlichen Verkehr jedoch dienen Vorurd Vatersname der korrekten Registrierung in allen nur denkberen Karteien und Listen. Im "Ersten Kreis" läBt sich Solženicyn bei der wohl für jeden Leser unvergeßlichen Schilderung $d \in r$ ersten Nacht, die der Diplomat Innokentij Volodin im MoskEuer Lubjanka-Gefängnis verbringt, nicht jenes zermürbende Frage- und Antwortspiel entgehen, das sich fast stereotyp mehrmals wiederholt:

$$
\begin{aligned}
& \text { "- Фамилия? - Володин. - Имя-отчество? - Сколько } \\
& \text { раз можно? - Имя-отчество! - Иннокентий Артемьич." }
\end{aligned}
$$

Ocer ein anderes Mal:

" - Фамилия? - Я уже отвечал! - возмутился Иннокентий. - Фамилия? - без выражения, как радист, вызываюший станцию, повторил пришедший." 
[Name? - Volodin. - Vorname, Vatersname? - Wie oft kann man denn? - Vorname, Vatersname! - Innokentij Artem'ič./Name? - Hab' ich doch gerade gesagt, empörte sich Innokentij. - Name? - wiederholte ohne Ausdruck, wie ein Funker, der eine Station anrief, der Eingetretene.]

Solženicyn behandelt die Namen als etwas sehr wichtiges, sie sind voll einbezogen in den zentralen Themenkreis, um den es bei ihm geht: die Beziehungen des Menschen zum Menschen. In "August 14" bemüht sich der 19jährige Jaroslav Charitonov, frischgebackener Unterleutnant, mit einem Feldwebel ohne Förmlichkeit ins Gespräch zu kommen. Da heißt es:

\footnotetext{
"Фельдребель такой был важный, плотный, и заметно старше Ярослава, что юному подпоручику неловко было перед ним за свои звездочки, неловко быть чином выше да, при тонкости фигуры, и ростом. Всю эту неловкость Ярослав старался искупить вехливым невоенным обрашением:

- Как мне вас называть, простите?

- Фельдфебель, как! - улыбался тот, вытирая пот с загорелого лица.

- Ну что вы! По имени-отчеству!

- По имени-отчеству в армии не зовут ...

- В человечестве - зовут.

- Меня и в человечестве всю жизнь только терентием.
}

[Der Feldwebel war so ernst, so stämmig und sichtbar älter als Jaroslav, daB der jugendliche Unterleutnant vor ihm verlegen wurde wegen seiner Sternchen, verlegen, im Rang uber ihm zu stehen und, bei seiner schmächtigen Figur, auch nach seiner Größe. All diese Verlegenheit suchte Jaroslav durch seine höfliche, unmilitärische Anrede wettzumachen: Wie kann ich zu Ihnen sagen, verzeihen Sie? - Feldwebel, wie denn sonst! - lachelte der, den Schweiß von seinem sonnverbrannten Gesicht wischend. - Aber nicht doch. Mit Vor- und Vatersnamen. - Mit Vor- und Vatersnamen redet man im Heer nicht an ... - Aber unter Menschen sagt man so. - Unter Menschen hat man mich auch das ganze Leben nur Terentij gerufen ....]

Die Tatsache, daß Solženicyn seine bekannte Lagererzählung "Odin den' Ivana Denisoviča" [Ein Tag des Ivan Denisovič] genannt hat, kann, so betrachtet, kein Zufall sein. Der Lager- 
häftiing Suchov geht in Soiženicyns Perspektive seiner Menschenwürde nicht verlustig, er fühlt sich selbst wie unter Menschen, wenn auch nicht wie unter lauter guten. Der Gebrauch der Namen und Anredeformen könnte, wenn man ihn weiter verfolgte, sehr wohl auch einen Ausblick auf die strukturale Ebene der Komposition eröffnen. Mit diesen Namen korrespondieren nämlich weitere sprachliche Eigenarten, Wertungen und erzählerische Ordnungsprinzipien, aus denen die Werke ihren Erzählrhythmus, anders gesagt, ihre Erzählperspektive gewinnen.

Es bestätigt sich hier genau das, was der russische Linguist Boris Uspenskij 1970 in seinem Buch "Die Poetik der Komposition" u.a. über Tolstojs "Krieg und Frieden" (Vojna i mir) ausgeführt hat. Auch bei Tolstoj ist es gar nicht gleichgültig, ob etwa von "Bonaparte", "Buonaparte" oder von "Napoleon" die Rede ist.

Die Fülle der bei Solženicyn auftretenden Personen stellt freilich nicht allein an unser Namensgedächtnis ungewöhnliche Anforderungen. Bequeme und rasche Identifikation wird dem Leser auch dadurch erschwert, $d a \beta$ er in ein ungeheuer breites Spektrum menschlicher Schicksale Einblick bekommt, und daß jedes Schicksal im Augenblick des Eintritts seines Trägers in die Handlung schon ein eigenes spezifisches Gewicht hat, sogar das Schicksal der Kinder. Daran zeigt sich deutlich, daß es Solženicyn nicht um eine psychologische Typisierung geht, nicht um die Darstellung eines typischen Bewußtseins, sondern um das, was er die soziale "Polyphonie" nennt, das oft problematische Zusammenwirken der einzelnen gesellschaftlichen Monaden.

Dieses in erzähltechnischer Hinsicht eher umständliche 
Verfahren fordert vor allem den häufigen und raschen Perspektivenwechsel, großen sprachlichen Takt und die Gabe der Einfühlung in ganz individuelle Wertsysteme. Da man Solženicyns eigenen Begriff der Polyphonie gelegentlich mit Michail Bachtins Dostoevskij-Buch verknüpft hat, wollen wir hier einen wesentlichen Unterschied zu Dostoevskij markieren. Dostoevskij verlagert das Erzählen bis in die Tiefenschichten des BewuBtseins seiner Helden, er gestaltet die Welt nach dem besonderen Hinblick und der Verfassung seiner Helden. Raskolnikovs enge Dachstube ist ebenso wie die gestaute Zeit ein Analogon zu seinem BewuBtsein, das sich nach Ausbruch aus der Enge, nach Proben seiner Macht sehnt. Die Haupthandlung, deren Spannung wir bei Dostoevskij so geradezu körperlich spüren, ist im Grunde die Verlängerung eines charakterologischen Entwurfs, mit anderen Worten die Probe oder das Experiment mit einer Idee, die sich ihrerseits mit anderen Ideen im Raum stöBt. Solženicyn reduziert dagegen die Handlung auf einen privaten Lebensausschnitt oder einen Ausschnitt aus der Geschichte, aber dieser Ausschnitt ist ein authentischer Ausschnitt, ist sogar oft nach Tag und Stunde verifizierbar.

"Wie verstehe ich die Polyphonie?" fragt Solženicyn in dem bekannten Interview mit Pavel Ličko, das 1967 in einer slovakischen Kulturzeitschrift erschien. "Eine Erzählung ohne Hauptheld ... Jede Person wird zur Hauptperson, wenn die Handlung sie betrifft. Bisweilen ist der Autor für 35 Helden verantwortlich. Keinem von ihnen gibt er den Vorrang. Jede von ihm geschaffene Gestalt muB er begreiflich machen und begründen. Doch darf er den Boden unter seinen Füßen nicht verlieren."

Ein Beispiel. Das 8. Kapitel der "Krebsstation" ist einer typischen Nebenfigur, dem Arbeiter Efrem Podduev gewidmet, 
dessen Person Solženicyn u.a. dazu dient, die Begegnung zwischen den Krebskranken und den hintersinnigen Volkserzählungen Leo Tolstojs anzuzetteln. Der alte biblische Vorname Efrem (Ephraim) liegt ganz auf der Linie des volkstümlichen, oder wie Lukács sagen würde, des bäuerlich-plebejischen Horizontes bei Tolstoj. Solženicyn fällt bei dieser Erzählung selbst in den Volkston, in die besondere Syntax der Volkssprache, in die Sprache der Volkslegende oder der Fabel, und zwar auch bei der Vorgeschichte seiner Krankheit, bei der Beschreibung des Halstumors, des Spickens der Zunge mit Radiumnadeln, bei der Schilderung der immer weiter ausfächernden Operationen. Das neutrale Wort "operieren", das hier in der deutschen Ubersetzung gebraucht ist: "und sie operierten ihn links und rechts am Hals", paßt eigentlich nicht so gut zu der anschaulichen und affektiven Beschreibung des Leidens, in der der Erzähler sich Efrems eigene Ferspektive, Efrems eigene Sprache zu eigen macht. Wörtlich lautet nämlich der Text:

"И его порезали справа и слева по шее, как режутся ножами блатари..."

[Und sie schnitten an seinem Hals rechts und links herum, so wie Kriminelle mit dem Messer arbeiten.]

Solženicyns Kunst besteht darin, auf knappstem Raum Efrems Lebensgeschichte, Efrems Krankengeschichte und seine individuelle Einstellung zum Leben und zur Welt zu umreißen. Efrem steht so als ganze Person vor uns, mit aller seiner erworbenen Weisheit und in einer gleichsam schon abgeschlossenen Entwicklung. Wie der tschechische Slavist Miroslav Drozda in seiner Studie über Solženicyn treffend bemerkt hat, sind die vielen Lebensgeschichten, die Solženicyn in die Fabel einbaut, nicht als Abrechnung oder als rückschauende Einkehr 
der betreffenden Figur zu verstehen, sondern als Aufdeckung möglicher Verhaltensweisen im zwischenmenschlichen Bereich. Solženicyns Realismus geht bei aller Verflechtung mit der russischen Literatur des 19. Jahrhunderts hier sehr eigene Wege, unter toerspringung etwa der Traditionen Gor'kijs oder Bunins.

Wenn man die Kontinuität der mussischen Literatur im Auge hat, darf man aber auf keinen Fall vergessen, daß bereits Ende der zwanziger Jahre von einer linken Gruppierung sehr energisch eine "Literatur der Fakten" gefordert wurde, eine Literatur, die dokumentarisch und nicht ausgedacht zu sein hatte. In seinem Essay "Woher und wohin?" (Otkuda $i$ kuda?) stellte Sergej Tret'jakov schon 1923 fest:

"С вымышленными людьми на вымышленных путях живет
читатель, совершает вымышленные поступки и прос-
тупки, чтоб вслед за тем снова стать косноязычным
и слепоногим атомом стихийно неорганизованного
общества. И там, где ему действительно нужно сло-
во в его повседневнй жизни, он его не находит."

[Mit erfundenen Menschen auf erfundenen Wegen lebt der Leser, vollführt erfundene Taten und Missetaten, um danach wieder ein stammelndes und blindes Atom der elementaren unorganisierten Gesellschaft zu werden. Und dort, wo er wirklich das Wort braucht in seinem alltäglichen Leben, findet er es nicht.]

Da, wo die Faktisten (wie sie sich selbst nannten) gegen eine "konventionelle Physiologie des Romans" stritten, dort, wo sie von der perspektivischen Verzerrung durch die zentrale Rolle des "Helden" sprachen, wo sie die genaue "Fixierung der Fakten" verlangten, ist Solženicyn ihr heimlicher Bundesgenosse. Bei ihm gibt es keine "proletarischen Werthers", über die man schon $1928 \mathrm{zu}$ lachen begann, bei ihm gibt es keine stereotype Psychologie des Helden, bei ihm ist Kunst kein "ästhetisches Narkotikum". Allerdings muB zum Unterschied von manchen 
Bestrebungen der zwanziger Jahre betont werden, daßs Solženicyn nicht das von Tret'jakov so genannte "ptolemäische System" der Literatur verlassen hat, daß er also doch ein "Belletrist" ist, daß er wie Tolstoj an die Beeinflussung des Lesers durch ästhetisch motivierte Verfabren glaubt. Wenn Solženicyn aber in dem Buch "Ein Tag des Ivan Denisovič" einen normalen Straflagertag in seiner vollen Chronologie ohne Beeinträchtigung durch ein spanrendes Sujet erzählerisch protokolliert hat, dann hat er das auch im Hinblick auf Tolstoj gewagt, dessen erstes erzählerisches Werk ein Beitrag zur Faktographie war: "Istorija včerašnego dnja" [Die Geschichte des gestrigen Tages], ein minutiöses und gewissenhaftes Seelenprotokoll, niedergeschrieben 1861 mit nur 23 Jahren.

Der Titel der "Krebsstation" nimmt ausarücklich auf einen Gegenstand Bezug, und kein Geringerer als Heinrich Böll hat dem Buch nachgerühmt, man erfahre daraus Erstaunliches über die Sorgfalt der ärztlichen Behandlung in der Sowjetunion. Im Mittelpunkt auch der BewuBtseinsdarstellung steht bei Solženicyn die Pioblematik der sozialen Existenz, bezogen auf die realen Einrichtungen und Gegebenheiten dieser Welt, und so erfaßt seine Darstellung auch die Biographie solcher Einrichtungen und der durch sie geprägten Gruppen. Den Ausdruck "sozialistischer Realismus", an dem Georg Lukács auch im Hinblick auf Solženicyn bis zuletzt gehangen hat, möchte ich hier deswegen vermeiden, weil er peinliche Assoziationen wachruft und weil Solženicyn wirklich etwas ganz anderes darstellt als dieienigen, die unter solcher Flagge gesegelt sind.

Biographie einer ganzen Gesellschaft könnte auch Solženicjns neuester Roman genannt werden, dessen erster Teil mit dem Titel "August 14" nun dem deutschen Leser in einer autorisierten Version angeboten ist. 
Der vorliegende Teil des Werkes, das der Autor selbst als das "wichtigste Projekt" seines Lebens bezeichnet hat, beschäftigt sich vor allem mit der Niederlage der russischen Armee des Generals Samsonov in Ostpreußen, mit der sogenannten Tannenbergschlacht. Unübersehbar ist jedoch auch, daB die Geschichte verschiedener russischer Familien, d.h. das Leben im Hinterland, den Vorgängen erst Relief gibt.

Eine äußerliche Parallele zu Tolstojs historischer Epopöe "Krieg und Frieden" ist dabei nicht nur, daß der zeitliche Abstand von etwas weniger als sechs Jahrzehnten ähnlich ausfällt, sondern auch, daß es Solženicyn mit dem Materialstudium, seien es primäre Geschichtsquellen, seien es private Dokumente und Nachrichten selbst aus der eigenen Familie, ähnlich genau nimmt. Aber es gibt auch wesentliche Unterschiede in der Perspektive. Tolstojs polemische Ironie gegenüber der Geschichtsschreibung scheint bei Solženicyn durch einen starken pädagogischen Affekt verdrängt zu sein. Das zeigt sich schon an den Volkssprichwörtern, die zwischen manche Kapitel montiert sind und die unmittelbar auf eine Moral abzielen: "Богатичи - что голубые кони: редко удаются." [Die Söhne der Reichen sind wie die blauen Pferde: sie geraten selten.] Oder: "Огня под полой не унесешь..." [Feuer kann man nicht unter dem Rockschoß verstecken.] Oder: "Не рок головы ищет - сама голова на рок идет." [Das Verhängnis sucht nicht den Kopf: der Kopf geht dem Verhängnis entgegen.]

Eine wesentliche Rolle als Beobachter und als Beurteiler der Lage spielt im Roman eine Person, die als Agent des Autors dient. Der Oberst im Generalstab Vorotyncev, dessen Rolle also sachlich motiviert ist, steht dabei zum Autor in einem streng distanzierten Verhältnis, das durch keine Intimitäten 
aufgelockert wird. Man muß schon lange tlättern, bis main auf den Vornamen Vorotyncevs stößt: Georgij oder russisch Egorij. Der ständige Gebrauch des Nachnamens wird so zu einem strukturellen Merkmal, insofern als Vorotyncev nur die Linse ist, in der sich die verschiedenen Ereignisse und Phasen der Schlacht zur gültigen Ordnung binden.

Als Verbindungsoffizier des Hauptquartiers eilt Vorotyncev von Schauplatz zu Schauplatz, in der stockenden Bewegung der Truppen bleibt er das mobile Element, sein Sachverstand wird bis zum zwangsweisen Verzicht auf fast jeden Schlaf in Anspruch genommen:

"Со своим характером он бы и не заснул: план выхода, расчеты и надежды выхода сверлили его, и теперь, пока это не сбудется, не мог бы он расслабиться и заснуть. Забега́ли мысли и дальше: что и как он расскажет в Стввке, если выйдет. И как это подействует."

[Mit seinem Charakter hätte er auch keinen Schlaf gefunden: der Ausbruchsplan, die Berechnungen und Hoffnungen um den Ausbruch bohrten. in ihm. Jetzt, bevor sich das alles erfüllt haben wïrde, hätte er nicht schwach werden und einschlafen können. Und seine Gedanken eilten noch weiter voraus: Was und wie er im Hauptquartier vortragen würde, wenn er herauskäme. Und was für eine Wirkung das haben wïrde.]

Wo der Autor selbst das Wort in der Deutung der verworrenen Vorgänge übernimmt, ist ihm Skepsis gegenüber Tolstojs fat $\mathrm{l}$ istischer Geschichtsphilosophie anzumerken. An einer Stelle sagt er ausdrücklich, er wolle sich über das Versagen der russischen Generalität nicht mit Tolstojs tberzeugung hinwegtrösten, daß nicht Generäle die Heere führten, daß nicht Kapitëne die Schiffe und nicht Führer die Parteien steuerten:

"да слишком много раз показал нам XX век, что именно о н и."

[allzuviele Male hat uns das 20. Jahrhundert gezeigt, daß genau sie all dies tun.] 
Wenn Solženicyn in seinem letzten Werk auf dem Gebiet der Geschichtsphilosophie gegen Tolstoj polemisiert, so ist gerade hierin ein Beweis dafür zu erblicken, daB "August 14" eine Bontrafaktur zu Tolstojs "Krieg und Frieden" ist und daB Solženicyn Tolstojs Tradition in keiner Weise als erschöpft ansieht. Nur muß man gerechterweise anmerken, daß Solženicyn sich von dieser Tradition jederzeit auch ironisch zu befreien versteht. Uber den fügsamen Romancier Galachov heiBt es im "Ersten Kreis" recht sarkastisch:

\begin{abstract}
"Но угнетало Галахова, что писать-то! - все трудней становилось писать кахдую новую хорошую страницу. Он заставил себя работать по расписанию, он боролся с зевотой, с ленивым мозгом, с отвлекающими мыслями, с прислушиванием, что пришел, кажется, почтальон, пойти бы посмотреть газетки. Он старался месяцами не заглядывать в Толстого, потому что толстовская навязчивая манера писать так и перла сама из его автоматической ручки."
\end{abstract}

[Nur das Schreiben selbst bedrückte Galachov. Immer schwerer wurde es ihm, jede neue schöne Seite zu schreiben. Er zwang sich dazu, nach einem Stundenplan zu arbeiten, er kämpfte mit dem Gähnen, mit dem faulen Gehirn, mit ablenkenden Gedanken, mit dem Lauschen darauf, daB anscheinend gerade der Postbote gekommen war. Man könnte ein bißchen in die Zeitungen schauen. Er bemühte sich monatelang keinen Tolstoj aufzuschlagen, denn die aufdringliche Tolstojsche Manier zu schreiben quoll ganz von selbst mit Macht aus seinem Füllfederhalter.]

Wichtiger als die Auseinandersetzung mit Tolstoj ist aber noch etwas anderes. Solženicyn möchte seinen russischen Leser zur Mündigkeit erziehen, und als tiefere Ursache der russischen MiBerfolge im Feldzug läßt er nicht gelten, daß etwa das Volk nicht habe kämpfen wollen, oder daB es unüberwindbare soziale Gegensätze gegeben habe. Die mangelnde Gewöhnung an selbständige Entscheidungen und die Unmündigkeit der zur Führung Berufenen werden für das Verhängnis fast allein verantwortlich gemacht. Die rein gesellschaftlichen Ursachen werden dagegen auf Kurzsichtigkeit und Korruption in den Hofkreisen reduziert. 
Gegen die Versäumnisse der Führer kann selbst der Volksgeist nichts ausrichten, und der Autor leitet sein 40. Kapitel mit folgendem elegischen Resümee ein:

"В четырехлетней войне, надорвавшей народный дух,
кто возьмется указать решаюшее сражение? Бесчис-
ленно было их, больше бесславных, чем прославлен-
ных, глотавших наши силы и веру в себя, безот-
дарно и бесполезно забиравших у нас самых смелых
и крепких, оставляя разбором похуже."

[In dem vierjährigen Krieg, der den Geist des Volkes zuschanden gemacht hatte, wer traute sich da zu, die entscheidende Schlacht zu nennen? Unermeßlich war ihre Zahl, mehr unrühmlich als rühmlich ihr Ausgang, ein Verschleiß unserer Kräfte und unseres Glaubens an uns selbst. Um die Tapfersten und Stärksten haben sie uns gebracht, eine schlechtere Auswahl übriglassend.]

Auch der Oberst Vorotyncev, Gewährsmann und Komplice des Erzählers, dem das Ausmaß der Katastrophe als erstem bewußt wird, muß seine persönliche Ohnmacht angesichts der dilettantischen Führung durch die obersten Stäbe einsehen. Dabei bringt gerade er, der $z u$ den entschlossensten Nachwuchsoffizieren gehört, zu den sog. "Jungtürken" oder auch, wie der Autor anmerkt, den potentiellen "Dekabristen" des 20. Jahrhunderts, beste intellektuelle, moralische und physische Voraussetzungen für einen persönlichen Erfolg mit. Als seine Lebensaufgabe sieht er es an, "günstigen Einfluß auf die Geschichte seines Vaterlandes zu nehmen", dieses in irgendeine "bessere" Richtung zu ziehen oder zu stoßen. Aber er weiß auch dies:
"Но силы такой, но влиянья такого не отпускалось в России отдельному человеку, не осененному близостью короны."
[Doch eine solche Macht, ein solcher Einfluß wurde dem einzelnen Menschen in Rußland nicht eingeräumt, wenn ihm nicht durch die Nähe der Krone der Segen dazu erteilt worden war.]

Eine zeitweilig euphorische Stimmung lernt Vorotyncev nur kennen, als er am 14. August dabei helfen kann, an einem 
besonders wichtigen Frontabschnitt den Geist der Verteidiger zu beflügeln und sogar einen taktischen Gegenangriff zu forcieren. Durch einen nachweisbar unsinnigen Rückzugsbefehl des Armeekorps wird dieser Erfolg zwar sofort wieder zunichte gemacht, aber Vorotyncev hatte doch schon triumphieren können, daB die vorderen Truppenteile selbst die Initiative ergriffen hatten, daß die unermeBlichen Kräfte des Volkes nun doch in Bewegung geraten waren.

Der Fall von diesem Stimmungsgipfel ist um so tiefer, als sich Vorotyncev in diesen Stunden einem einfachen Soldaten verbunden weiB, der ihm im richtigen Augenblick begegnet ist. Arsenij Blagodarev, der ideale tapfere Untergebene und später sogar Freund, erscheint Vorotyncev wie ein besonderes Symbol dieser Gegenaktion, von ihm vermag er sich in den nächsten Tagen nicht zu trennen.

Solženicyn liefert hier den Beweis, daß er die Namen oft auch im Sinne ihrer Etymologie verwendet, als redende oder sprechende Namen. Vorotyncev reflektiert beim ersten Hören des Namens Blagodarev, in dem sich die Bedeutung "Dank sagen" verbirgt, über eben diese Bedeutung:

"Ловкая подхватистая фамилия, и так же подхватисто он выговорил ее, теплым помелом прошел по сердиу. Благодарев!"

[So ein gelungener, treffender Name, und so treffend sprach er ihn aus, daß er wie ein warmes Zeichen das Herz traf. Blagoradev!]

Dieser idealisierte und - im Sinne Tolstojs - plebejischvolkstümlich stilisierte russische Soldat weiß nichts von Kadavergehorsam und zeigt nie eine Spur von Unterwürfigkeit. In Vorotyncevs Perspektive erscheint er folgendermaßen:

"И через дым счастья, дым боя, дым несвязанности бы- 
тия все время видел он еще лицо Благодарева: никогда не услужливое, а всегда достойноготовное, доброжелательное даже до снисходительности, не дерзкое, но живущее осмысленной отдельной волей."

[Durch den Dunst des Glücks, durch den Dunst des Gefechtes, durch den Dunst der Ungereimtheit des Daseins sah er die ganze Zeit auch noch das Gesicht Blagodarevs vor sich: niemals beflissen, sondern immer voll wïrdiger Bereitwilligkeit. Wohlwollend bis zur Nachsicht, nicht vermessen sondern belebt von einem besonnenen, selbständigen, freien Willen]

Vorotyncev findet also wie Pierre in "Krieg und Frieden" seinen Flaton Karataev, nur daß Solženicyn an ihm weniger seine Lebensweisheit als seine innere Freiheit, seine Mündigkeit herausarbeitet. Arsenij ist gerade in schwierigen Lagen gut $2 u$ gebrauchen, und so macht ihn Solženicyn zu einem der Protagonisten in den Szenen, die die schmale Fabel des Romans ausmachen: den Ausbruch einer kleinen Gruppe unter Führung des Obersten Vorotyncev aus dem deutschen Kessel.

Hier geschieht es dann auch, daß sich wie in einem Knoten die Erzöhlstränge der zentraleren Personen miteinander verwickeln, was ja zum traditionellen Ablauf einer Romanfabel gehört. Im Verlauf dieser Szenen tritt auch der oberkommandierende General Samsonov auf, der in diesem Roman die tragische Figur abgibt. Obwohl vollkommen klar ist, daß Solženicyn die äuBerlichen Gründe für das Scheitern der russischen Strategie darin sieht, daß die Führung nicht die Bedeutung der modernen Technik für die Kriegführung erkannt hatte, also ohne Nachrichtentechnik, Flugaufklärung und Transportmittel nach Berlin marschieren wollte, bleibt General Samsonov in den Mantel einer fast Don-Quijotehaften Ritterlichkeit gekleidet. Sein letzter Vorbeiritt an den versprengten Truppen erscheint Vorotyncev wie ein "langsamer, herrscherlicher, vorpetrinischer Ritt" und die ihm nachschauenden Augen der Soldaten blicken 
nicht böse sondern gutmütig auf dieses "entblöBte Haupt voller erhabener Traurigkeit."

"August 14" ist auch ein Epos, und zum Ausdruck der Poesie episch überhöhter Bilder hat Solženicyn das zeitgemäße Mittel der Filmperspektive zu Hilfe genommen. In Montageszenen, die als "Filmleinwand" (Ecran) bezeichnet sind, erscheinen symbolische Bildvorgänge, etwa die brennenden Windmühlenflügel als feuriges Schicksalsrad, die Georgsfahne, die von den letzten Getreuen in die ostpreußische Erde versenkt wird, der Nahkampf mit dem Bajonett, der Pferdekopf in Großaufnahme, die Perspektive des herrenlosen Pferdes, die verirrten Tiere, das mit sinnlosen Gegenständen übersäte Schlachtfeld:

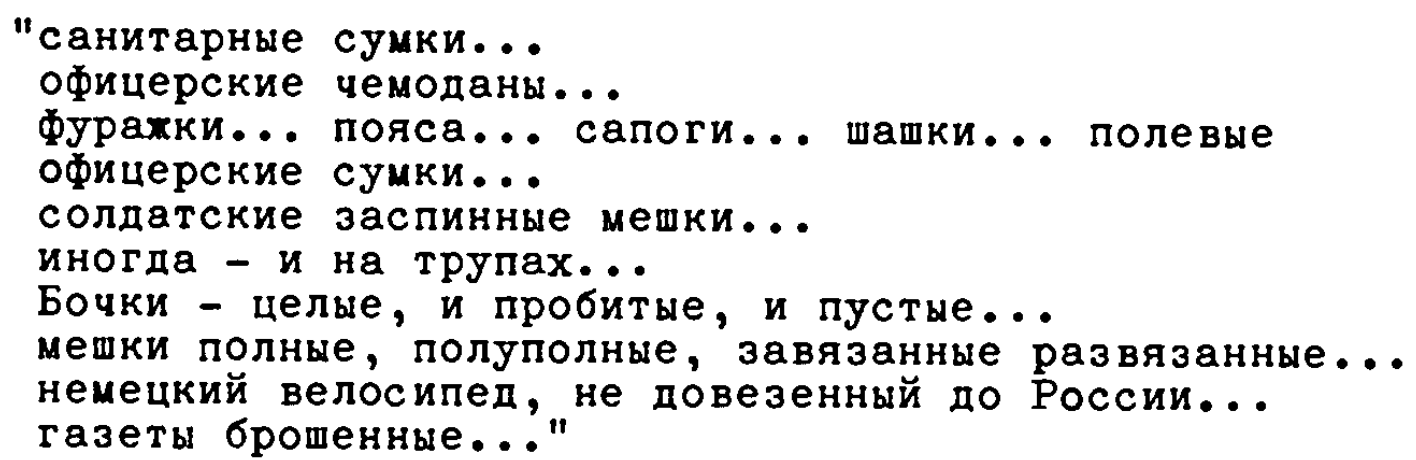

[Sanitätstaschen, offizierskoffer ... Schirmmützen ... Koppel ... Stiefel ... Säbel ... Feldbeutel von offizieren ... Ranzen von einfachen Soldaten ... manchmal auch auf dem Rücken von Toten ... Fässer - ganze und durchschossene und leere ... Säcke, gefüllte und halbvolle, zugebundene und aufgebundene, ein deutsches Fahrrad, das den Transport nach RuBland nicht erlebt hatte ... fortgeworfene Zeitungen ....]

Auf dieser Erzählebene gibt es auch echte epische Vergleiche und Metaphern, etwa wenn der Geschoßhagel - wie schon in der mittelalterlichen russischen Kriegserzählung - mit der Bewegung von Dreschflegeln auf der Tenne verglichen wird. Solženicyn bevorzugt hier bäuerliche Metaphern oder Vergleiche, die bis in das Gebiet der Strategie reichen. Die beiden russischen Angriffsspitzen in Ostpreußen, die Armee des Generals 
Rennenkampf und die Armee des Generals Samsonov werden mit einem gehörnten Stierkopf verglichen, nicht mit einer Dampfwalze, wie es die deutsche Perspektive wollte.

Manche Vergleiche erinnern aber auch an Tolstojs berühmte physikalische Vergleiche, so wenn es von der militärischen Lage heiBt:

"Отступленье само начинало течь, как течет и твердый металл, никого не спрося, лишь свою температуру плавления."

[Der Rückzug geriet von selbst ins Fließen, so wie auch schweres Metall fließt, ohne jemand zu fragen außer seiner Schmelztemperatur.]

Ein souveräner Standpunkt wird hier deutlich ebenso wie in den geschichtsphilosophischen Abschweifungen oder in den die Handlung transzendierenden Sentenzen, von denen die pessimistischste vielleicht diese ist:

"Плохие люди все друг друга поддерживают, в этом
главная сила их."

[Die schlechten Menschen unterstützen siç alle gegenseitig, darin besteht ihre größte Stärke.]

Der Kampf Mann gegen Mann wird von Solženicyn in diesem Roman nicht übermäßig verherrlicht, aber er wird auch nicht aus dem menschlichen Bereich verdrängt. Der Krieg wird von Solženicyn weder als Naturereignis noch als notwendig und unvermeidbar hingestellt, eher im Gegenteil, aber eine ideologisch begründete "Ohne-mich"-Haltung ist seinem Naturell ganz offensichtlich fremd. Im Vordergrund steht hier wieder d:e Solidarität mit dem Nächsten, nicht mit dem tbernächsten.

Solženicyns pädagogischer Affekt tritt auf diesem Gebiet besonders in den Szenen mit dem Fähnrich Lenartovič in den Vordergrund. Saša Lenartovič, im zivilen Leben Student der Petersburger Universität, ist ein glühender und überzeugter Feind des zaristischen Regimes und wartet nur noch 
auf die Revolution. Seine Einstellung zum Krieg ist: "Je schlimmer desto besser." In Lenartovič ringen zwei Gefühle miteinander, der Wunsch, aus dem verhaßten Krieg zu dersertieren und der Instinkt, sein Leben so teuer wie möglich zu verkaufen.

Saša Lenartovič nimmt in der Gruppe mit dem Oberst zunächst eine kritische Haltung ein. Der Oberst Vorotyncev gefällt ihm zwar nicht so schlecht, aber andererseits

"если он истинно-образованный, да еще имеет власть, как же мог он поддаться темному немому завету зтих диких запасных из нечесанных углов России?"

[wenn er wirklich gebildet war und dazu noch die Macht hatte, wie konnte er sich da der dunklen stummen Willensordnung dieser unaufgeklärten Reservisten aus den ungekämmten Ecken RuBlands unterordnen?]

Die vor dem Ausbruch aus der Umzingelung Stehenden haben sich ganz zufällig zusammengefunden, unter ihnen befinden sich auch Angehörige eines der im Kampf zerschlagenen Regimenter, des Regiments von Dorogobuž. Diese versprengten Kämpfer tragen noch die Leiche ihres gefallenen Regimentskommandeurs, den sie nicht in Feindeslandbegraben wollen, und außerdem ist bei ihnen ein verwundeter Offizier, der sich die Regimentsfahne un den Leib gewickelt hat. Lenartovič ist ungehalten, daß man sich mit diesen Leuten da noch belastet. Für ihn ist die Fahne bloB ein "reichseigener Fetzen", der Offizier riecht ihm nach einem typischen Reaktionär und den Toten noch weiter zu tragen, hält er für absolute Barbarei.

"Was ist denn das für ein moderner Krieg?" versucht er den Obersten zu bedrängen:

"Современная война встретит нас на шоссе, прапорщик. 
Вы бы прехле попумали - чем булете стрелять? Этой пукалкой не настреляешь."

[Der moderne Krieg wird uns an der Chaussee empfangen, Fähnrich. Sie hätten besser schon mal daran denken sollen, womit Sie eigentlich feuern werden. Mit der Knallbüchse da werden Sie nicht viele Ringe schließen.]

Die kurze Auseinandersetzung zwischen den beiden endet mit einer für Solženicyn typischen Sentenz, die ihre anschauliche Wahrheit nur aus der ganzen Situation gewinnt, getreu dem von Solženicyn im Roman zitierten Sprichwort.

"Коротка разгадка, да семь верст правды в ней."

[Kurz ist die Lösung, aber ihre Wahrheit ist sieben Werst lang.]

Vorotyncev hat dem Fähnrich eben klar gemacht, daß es jetzt nicht auf weltanschauliche Gegensätze ankomme, und auf die Gegenfrage, ob vielleicht nationale Widersprüche wichtiger seien, welche Gegensätze denn überhaupt Geltung beanspruchen dürften, antwortet Vorotyncev:

"Между порядочностью и непорядочностью."

[Zwischen Anstand und Unanständigkeit.]

"August 1914" ist ein Buch, dem naturgemäß eine größere Offenheit eigen ist, auf dem eine größere uneingelöste Hypothek lastet als das bei einem vollendeten Werk üblich ist. Der russische Leser, für den dieses Buch geschrieben ist, und den es zugleich am schwersten erreicht, wïrde zweifellos leidenschaftlicher auf diese Bewertung der Rolle Rußlands im ersten Weltkrieg reagieren als es westliche Kritiken bisher getan haben. Wenn dem Dichter die Vollendung dieses großzügig konzipierten Werkes glückt, darf man aber wohl weitere ungewohnte Ausblicke auf das geschichtliche Selbstverständnis und die geschichtliche Selbstachtung der Russen von ihm erwarten. Moralisch und

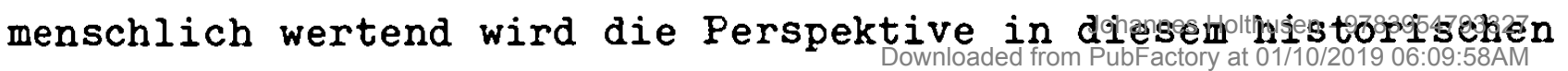


Prolog zu einem zeitgeschichtlich of fenbar sehr beziehungsreichen Werk eingerichtet. Eine abschließende Bewertung wird man heute nicht wagen können, aber die suggestive Erzählkunst Solženicyns braucht deswegen niemanden unbeteiligt zu lassen. Solženicyn schreibt für den Leser unserer Zeit, sein Appell ist noch nicht durch die Geschichte überholt.

L i t e r a turangaben

B a c h t i n, Michail: Problemy poètiki Dostoevskogo. Moskva 21963.

D r $\circ 2$ d a, Miroslav: Babel', Leonov, Solženicyn. Praha 1966. G $\circ$ g $\circ I^{\prime}, N_{. V}$ : Svetloe voskresen'e. In: Vybrannye mesta iz perepiski s druz'ami. (=N.V. Gogol': Polnoe sobranie sočinenij, t. 8 .

I $i$ č $k$ o, Pavel: Alexander Solschenizyn im Gespräch. In: A. Solschenizyn: Von der Verantwortung des Schriftstellers, I. Zürich 1969 (Edition 'Arche Nova').

Literatura fakta. ( = N.F. Cužak (Hrsg.): Faktographische Literatur. Nachdruck der Ausgabe Moskau 1929 mit einer Einleitung von Hans Günther. Centrifuga Vol. 10. München 1972.)

L u k a c s, Georg: Solschenizyn. Neuwied und Berlin 1970.

$S \circ$ I s c h e $n i z$ y $n$, Alexander: Uber die russische Sprache. In: A. Solschenizyn: Von der Verantwortung des Schriftstellers, I. Zürich 1969 (Edition 'Arche Nova').

S 0 l s c h e $n i z$ y $n$, Alexander: Krebsstation. Roman in zwei Büchern. Mit einem Vorwort von Heinrich Böll. Buch I. Neuwied und Berlin 1968.

$S \circ 1 \check{z}$ e $n i c y n$, Aleksandr: Odin den' Ivana Denisoviča. Povest'. Moskva 1963 (Sovetskij pisatel').

$S \circ I$ z e $n$ i c y n, Aleksandr: Rakovy j korpus. Povest' $v$ dvuch častjach. Paris 1968 (YMCA).

$S \circ l$ ž e $n$ i c $\mathrm{y} n$, Aleksandr: $\mathrm{V}$ kruge pervom. New York Frankfurt/M. 1968.

S $\circ$ l ž e n i c y n, Aleksandr: Avgust četyrnadcatogo ( 10 - 21 avgusta st. st.). Uzel I. Paris 1971 (YMCA).

T r e t'j a k o v, Sergej: Otkuda i kuda? (Perspektivy futurizma). LEF, 1923, I.

U s p e n s k i j, B.A.: Poètika kompozicii. Moskva 1970. 
VERZEICHNIS WEITERER, THEMATISCH ANKNÜPFENDER ARBEITEN

DES VERFASSERS

Studien zur Asthetik und Poetik des russischen Symbolismus. (Habilitationsschrift.) Göttingen 1957.

Versdichtung der russischen Symbolisten. Ein Lesebuch. Herausgegeben von Johannes Holthusen und Dmitrij Tschižewskij. Wiesbaden 1959. (= Heidelberger slavische Texte. 5/6.)

Fedor Sologubs Roman-Trilogie (Tvorimaja legenda). Aus der Geschichte des russischen Symbolismus. Den Haag 1960.

(= Musagetes. 9.)

Russische Gegenwartsliteratur I (1890-1940). Bern, München 1963. (= Dalp-Taschenbücher. 368 D.)

Russische Gegenwartsliteratur II (1941-1967). Bern, München 1968. (= Dalp-Taschenbücher. 369 D.)

Twentieth Century Russian Literature. A Critical History. New York 1972. [Englische übersetzung der "Russischen Gegenwartsliteratur I-II".]

Andrej Belyj und Rudolf Steiner. In: Festschrift für Max Vasmer zum 70. Geburtstag. Ber'in 1956, S. 187-192.

Zur literarischen Typologie und zum Motivbestand der "Petersburger Erzählungen", insbesondere bei Puškin und Gogo"'. In: Die welt der Slaven 4, 1959, S. 148-168.

Nachwirkungen der Tradition in A. Bloks Bildsymbolik. In: Slawistische Studien zum $V$. Internationalen Slawistenkongre $B$ in Sofia 1963. Göttingen 1963, S. 437-444. (= Opera slavica. 4.)

Erzählung und auktorialer Kommentar im modernen russischen Roman. In: Die Welt der Slaven 8, 1963, S. 252-267.

Das Verhältnis von Futurismus und Konstruktivismus in der russischen Versdichtung. In: Archiv für das Studium der neueren Sprachen und Literaturen 201, 1964, S. 29-39.

Stilistik des "uneigentlichen" Erzählens in der sowjetischen Gegenwartsliteratur. In: Die Welt der Slaven 13, 1968, S. 225245.

Antiapolinski tip ruskog simbolizma. In: Književna smotra 4, Zagreb 1970, S. 73-79.

Prilog problemu estetskoga razvoja sovjetske književnosti od 1918. do 1923. In: Umjetnost riječi 15, Zagreb 1372, S. 137148. 
Die Bedeutung des Stils bei Andrej Belyj. In: Russian Literature 5, 1973, S. 65-78.

K. Moð̌ul'skij: Aleksandr Blok, Paris 1948; ders.: Andrej Belyj, Paris 1955. In: Zeitschrift für slavische Philologie 24, 1956, S. 419-424.

G. Donchir: The Influence of French Symbolism on Russian Poetry, Den Haae 1958. In: International Journal of Slavic Linguistics and Poetics 4, 1961, S. 157-161.

R. Poggioli: The Poets of Russia 1890-1930, Cambridge, Mass. 1960. In: Die Welt der Slaven 7, 1962, S. 214-217.

S. Makovskij: Na Parnase "serebrjanogo veka", München 1962 ;

F. Stepun: Mystische Weltscrau. Fünf Gestalten des russischen Symbolismus, München 1964. In: Zeitschrift für slavische Philologie 32, 1965, S. 434-442.

A. Hönig: Andrej Belyjs Romane. Stil und Gestalt, München 1965. In: Zeitschrift für slavische Philologie 34, 1967, S. 408-410.

Z. Mathauser: Die Kunst der Poesie. Stufen, die zur OktoberDichtung hinführten, Prag 1967. In: Poetica 2, 1968, S. 571574 . 